ERIKA NAKAJIMA

\title{
INVESTIGAÇÃO DE PROTEÍNAS CANDIDATAS VACINAIS CONTRA LEPTOSPIROSE. APRESENTAÇÃO DE ANTÍGENOS NA FORMA DE PROTEÍNAS RECOMBINANTES PURIFICADAS OU COMO VACINAS VIVAS EM SALMONELAS ATENUADAS
}

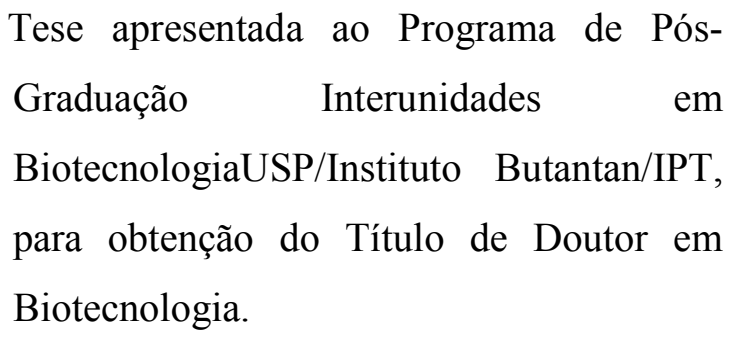


INVESTIGAÇÃO DE PROTEÍNAS CANDIDATAS VACINAIS CONTRA LEPTOSPIROSE. APRESENTAÇÃO DE ANTÍGENOS NA FORMA DE PROTEÍNAS RECOMBINANTES PURIFICADAS OU COMO VACINAS VIVAS EM SALMONELAS ATENUADAS

Tese apresentada ao Programa de Pós-Graduação Interunidades em BiotecnologiaUSP/Instituto Butantan/IPT, para obtenção do Título de Doutor em Biotecnologia.

Área de concentração: Biotecnologia

Orientadora:

Prof. Dra. Elizabeth Angelica Leme Martins 
DADOS DE CATALOGAÇÃO NA PUBLICAÇÃO (CIP)

Serviço de Biblioteca e Informação Biomédica do

Instituto de Ciências Biomédicas da Universidade de São Paulo

reprodução não autorizada pelo autor

Nakajima, Erika.

Investigação de proteínas candidatas vacinais contra leptospirose. Apresentação de antígenos na forma de proteínas recombinantes purificadas ou como vacinas vivas em Salmonelas atenuadas / Erika Nakajima. -- São Paulo, 2010.

Orientador: Elizabeth Angelica Leme Martins.

Tese (Doutorado) - Universidade de São Paulo. Instituto de Ciências Biomédicas. Programa de Pós-Graduação Interunidades em

Biotecnologia USP/IPT/Instituto Butantan. Área de concentração:

Biotecnologia. Linha de pesquisa: Desenvolvimento de Vacinas.

Versão do título para o inglês: Investigation of proteins vaccine candidates against leptospirosis. Antigens presentation as purified recombinant proteins or as live vaccines, by attenuated Salmonellas.

Descritores: 1. Leptospirose 2. Vacinas 3. Salmonela vacinal recombinante SL3261 4. SoxRS 5. Expressão de antígenos in vivo 6. Leptospira interrogans I. Martins, Elizabeth Angelica Leme II. Universidade de São Paulo. Instituto de Ciências Biomédicas. Programa de Pós-Graduação Interunidades em Biotecnologia USP/IPT/Instituto Butantan III. Título. 


\section{UNIVERSIDADE DE SÃO PAULO \\ INSTITUTO DE CIÊNCIAS BIOMÉDICAS}

Candidato(a):

Erika Nakajima.

Título da Tese:

Investigação de proteínas candidatas vacinais contra leptospirose. Apresentação de antígenos na forma de proteínas recombinantes purificadas ou como vacinas vivas em Salmonelas atenuadas.

Orientador(a): $\quad$ Elizabeth Angelica Leme Martins.

A Comissão Julgadora dos trabalhos de Defesa da Tese de Doutorado, em sessão pública realizada a considerou

\section{( ) Aprovado(a) \\ ( ) Reprovado(a)}

$\begin{array}{ll}\text { Examinador(a): } & \text { Assinatura: } \\ & \text { Nome: ....... } \\ & \text { Instituição: } \\ \text { Examinador(a): } & \text { Assinatura: } \\ & \text { Nome: ....... } \\ & \text { Instituição: } \\ \text { Examinador(a): } & \text { Assinatura: } \\ & \text { Nome: ........ } \\ & \text { Instituição: } \\ \text { Examinador(a): } & \begin{array}{l}\text { Assinatura: } \\ \text { Nome: ........ }\end{array} \\ & \text { Instituição: } \\ & \text { Assinatura: } \\ \text { Presidente: } & \text { Nome: ......... } \\ & \text { Instituição: }\end{array}$ 


\section{CERTIFICADO}

Certificamos que o Protocolo para uso de animais em experimentação $n^{\circ}$ 252/06, sobre o projeto intitulado "Utilização de Salmonella typhimurium com patogenicidade atenuada como ferramenta na investigação de antígenos vacinais contra leptospirose", sob a responsabilidade de Elizabeth Angélica Leme Martins está de acordo com os Princípios Éticos na Experimentação Animal adotado pelo Colégio Brasileiro (COBEA) e foi aprovado pela COMISSÃO DE ÉTICA NO USO DE ANIMAIS DO INSTITUTO BUTANTAN (CEUAIB) em reunião de 14/03/2006.

São Paulo, 17 de março de 2006.

De acordo:

Dr. Otávio Azevedo Mercadante

Diretor do Instituto Butantan

Dra. Denise V. Tambourgi

Presidente da CEUAIB

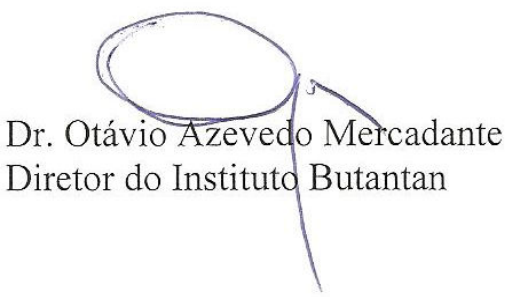


Dedico este trabalho a minha família, por todo apoio e incentivo. 


\section{AGRADECIMENTOS}

À Dra. Elizabeth Angelica Leme Martins, muito mais que minha orientadora, pela oportunidade, pela confiança, pelos ensinamentos, pela amizade. Obrigada por me ligar, mesmo depois de ter tirado a pior nota da FUNDAP, você começou a me orientar a partir deste momento, hoje sou apaixonada pelo o que eu faço. Para mim você é um exemplo de pessoa dedicada, determinada, batalhadora, de força, de bom humor, de caráter. Te admiro porque você quer abraçar a mundo, mas seus bracinhos são pequenos para tanto, espero um dia poder retribuir e te ajudar a abraçar um pedacinho. Obrigada por reconhecer o meu trabalho, para mim isso é mais importante do que qualquer título.

À Dra. Elisabeth Cheng e ao Dr. Alexandre Yague Lopes por sempre estarem por perto e dispostos a ajudar, pelas conversas e conselhos.

Ao Dr. Silvio Arruda Vasconcellos por abrir as portas do seu laboratório e por transmitir a experiência que possui.

À todo pessoal do laboratório de zoonoses da FMVZ da USP, principalmente à Zenaide, Amane, e Gisele pela ajuda, pelos ensinamentos nos ensaios com animais e pela paciência. A participação de vocês foi fundamental para a realização deste trabalho.

À Dra. Patrícia Abreu pela ajuda nos ensaios com animais. Obrigada pelos conselhos e dicas, por passar um pouquinho da sua experiência de anos de pesquisa e dedicação.

Aos meus familiares por todo incentivo, apoio e carinho. Principalmente aos meus pais, Mário e Yukimi, a quem devo toda minha educação e formação. Tenho orgulho de te-los como exemplo de vida, força, determinação. Aos meus irmãos, Lincoln e Karina, que sempre torceram por mim, mesmo sendo a mais irresponsável da família.

Ao amor da minha vida, Felipe, por sempre estar ao meu lado. Por sempre tentar me entender, mesmo que às vezes não conseguisse, por todo amor, carinho e companheirismo, por me agüentar por tanto tempo, por nunca desistir de mim.

Aos pequenos anjos que fizeram e fazem parte da minha vida, Lili, Indiana, Lucky, Dai e Dotty. Obrigada por alegrarem todos os meus dias, por me ensinarem a superar a dor da perda, e me fazerem sentir querida e amada mesmo nos meus piores dias.

À Dani por ser uma amiga para todas as horas, por me ajudar nos meus experimentos no laboratório, colocando a mão na massa e me ajudando a pensar. Obrigada por ser minha companheira de sangrias, de horas extras no laboratório, de tantos anos. Obrigada não só por ser minha confidente nos momentos de angústia, raiva e desconsolo, mas por estar presente nos momentos de alegria.

As minhas irmãs de coração, Patt e Rô, por tudo e mais um pouco. Patt, obrigada por ser essa amiga maravilhosa, palhaça, por me proporcionar momentos engraçados, porque coisas estranhas acontecem só quando você está dentro do carro. Você é um exemplo de determinação, nunca 
duvidei de você. Rô, obrigada por estar sempre ao meu lado, você é um exemplo de mãe e amiga, batalhadora sempre. Vocês são pessoas especiais pra mim, com certeza vou escolher vocês para fazerem parte das minhas vidas futuras.

À Claudia pela amizade sincera e por me dar suporte, mesmo nos momentos estressantes, como a qualificação, pela ajuda no laboratório, por tentar me ensinar a mexer no akta, um dia eu consigo. Claudete, espero que saiba o quanto você é importante para mim, e que pode contar comigo sempre, principalmente para comer milho.

À Bia pela amizade e pelo apoio sempre. Pela companhia durante o almoço e nas idas ao bar.

À Camilla por ser uma amiga maravilhosa e generosa, por me ensinar muitas coisas, me ajudar a refletir e buscar alternativas. $\mathrm{Ca}$, te admiro muito por tudo que você é, sinto sua falta no laboratório.

Ao Henrique por todo apoio. Obrigada por estar sempre por perto, me fazendo rir, pelas conversas, por compartilhar o gosto em muitas coisas. Henrique, depois da defesa me aguarde, vou devorar a Torre.

À Lu Leão e à Vivian, que se tornaram amigas valiosas, para todos os momentos. Lu, você é um exemplo de garra e coragem, de bom coração, você me mostrou que nunca devemos desistir dos nossos sonhos mesmo quando temos que tomar caminhos opostos. Vi, obrigada por me ajudar no laboratório, por me dar apoio, por ser minha companheira de lepto, por ser essa amiga doida demais.

Aos meninos, Juliano, Mateus, Paulo e Bruno, pelas conversas jogadas fora durante o almoço, pelas risadas e idas ao bar. Mateus, obrigada por me acompanhar desde o começo, aprendemos juntos muitas coisas.

À Luana por seu alto astral, como diz a Beth, por ter me ensinado muito quando entrei sem saber nada no laboratório. Lu, sinto sua falta no laboratório, mas você estará sempre no meu coração.

À Tati por ser um exemplo de organização, de trabalho duro e de pessoa estudiosa. Obrigada por me ajudar no laboratório, por ser companheira na busca de uma vacina, um dia a gente chega lá.

Às pessoas que sempre me auxiliaram no laboratório, sem elas nada disso seria possível, Dona Luisa, Carmen, Sueli, Joselino e Arleide. Obrigada por tudo, por estarem sempre por perto para colocar ordem no laboratório, por fazerem parte da minha vida, pelas conversas descontraídas.

Ao pessoal da secretaria de biotecnologia, Marcos, Fábia e Eliane, por estarem sempre dispostos a ajudar, por me salvarem em momentos de desespero com prazos e relatórios para entregar.

Ao Dr Paulo Lee Ho e a Dra Luciana Leite por disponibilizarem os equipamentos do laboratório. À Dra Maria Leonor Sarno pela ajuda nas sangrias dos animais e à Dra Elisabete SbrogioAlmeida por ensinar a manipular animais de laboratório sempre de maneira respeitosa. 
À todos amigos que me ajudaram e me incentivaram de alguma forma dentro e fora do laboratório, Moniquinha, Márcia, Anna Paula, Paulo Vinícius, Nati, Aline, Estela, Hebert, Cris, Lud, Kátia, Darlene, Ray, Fátima, Dona Salete, Marisa, Odila, Omar, Cibele, Enéas, Léo, Izilda, Carol, Giovane, Nidia, Toninho.

À todos os pesquisadores, alunos e funcionários do Centro de Biotecnologia do Instituto Butantan por fazerem parte de alguma forma da minha formação.

À todos os professores que tive durante a pós graduação, em especial a Dra. Elisabete Vicente que me deu a oportunidade de ser monitora no curso de microbiologia básica para alunos de graduação da medicina. Foi uma experiência maravilhosa.

Às agências financiadoras CAPES, Fundação Butantan, CNPq e FAPESP que apoiaram o desenvolvimento deste projeto.

À bibliotecária Mônica pela orientação na formatação e correção das referências desta tese.

À todos que me apoiaram e me ajudaram durante a realização deste projeto e que por algum motivo esqueci de colocar aqui. Fica aqui minhas sinceras desculpas, mas espero que entendam. 
"É melhor tentar e falhar, que preocupar-se e ver a vida passar: é melhor tentar, ainda que em vão, que sentar-se fazendo nada até o final.

Eu prefiro na chuva caminhar, que em dias tristes em casa me esconder.

Prefiro ser feliz, embora louco, que em conformidade viver" Martin Luther King

"Celebrate we Will Because life is short but sweet for certain We're climbing two by two To be sure these days continue Things we cannot change" David J. Matthews 


\section{RESUMO}

NAKAJIMA E. Investigação de proteínas candidatas vacinais contra leptospirose. Apresentação de antígenos na forma de proteínas recombinantes purificadas ou como vacinas vivas em salmonelas atenuadas. 2010. $178 \mathrm{f}$. Tese (Doutorado em Biotecnologia) Interunidades em Biotecnologia, USP/Instituto Butantan/IPT, São Paulo, 2010.

A leptospirose é uma doença de importância global que acomete humanos e alguns animais, causada por bactérias do gênero Leptospira. No Brasil são notificados cerca de três mil casos da doença em humanos por ano e 10\% chegam a óbito. A leptospirose é um problema sério especialmente nos grandes centros urbanos devido à quantidade de roedores que são reservatórios de leptospira. A melhor forma de controle da leptospirose seria a prevenção com medidas de saneamento básico e conscientização da população. O projeto para sequeciamento do genoma da Leptospira interrogans sorovar Copenhageni coordenado por um grupo de pesquisadores do Instituto Butantan e projeto Genoma funcional para desenvolvimento de vacina contra leptospirose, no qual nosso trabalho se insere, foram incentivados para necessidade de uma vacina eficaz para humanos. Além de estudos com proteínas recombinantes, abordamos também a estratégia de utilização de salmonela vacinal como apresentadora dos antígenos expressos in vivo. Após a análise do genoma da Leptospira interrogans sorovar Copenhageni por bioinformática, selecionamos e amplificamos 10 genes, LIC10191, LIC10793, LIC12302, LIC11227, LIC13101, LIC12033, LIC12659, LIC10537, LIC10508 e LIC10868. Nos ativemos ao estudo de seis antígenos codificados pelos seis primeiros genes listados, além das proteinas Lip32 (LIC11352) e Lig A (LIC10465). Os genes foram clonados em vetor pAE e pAEsox. As proteínas foram expressas in vitro em E. coli e purificadas por IMAC. Construímos plasmídeos carregando dois genes e testamos a capacidade da salmonela de expressar simultaneamente dois antígenos heterólogos in vivo. As proteínas LIC10191 e LIC10793 foram utilizadas como proteínas purificadas ou expressas em salmonelas recombinantes, SLLIC10191 e SLLIC10793, em ensaios de imunização de camundongos. As salmonelas recombinantes administradas pela via intraperitoneal induziram maior resposta imune contra os antígenos em relação a administração pelas vias intranasal e oral. A resposta imune de anticorpos específicos gerada contra os antígenos purificados foi sempre maior do que quando os antigenos foram apresentados por salmonelas. Um resultado importante foi a proteção parcial em hamsters imunizados com a SLLIC10191 e desafiados com Leptospira interrogans sorovar Pomona. Em outro ensaio, observamos que a 
imunização com as salmonelas induziu produção de anticorpos contra dois antígenos expressos in vivo simultaneamente. Nesse ensaio não houve proteção dos hamsters imunizados desafiados com Leptospira interrogans sorovar Copenhageni. Os ensaios de imunização e desafio com a Leptospira interrogans sorovar Copenhageni não foram conclusivos. Esse sorovar apresentou diferenças marcantes em relação ao sorovar Pomona, resultando em maior dificuldade de manipulação e de adequação da dose de desafio. Algumns parâmetros foram considerados e investigados, como a variação na virulência das leptospiras durante cultivo in vitro e a dificuldade na precisão da contagem de bactérias a serem administradas por animal, além das dificuldades intrínsecas dos ensaios de desafio, como a interferência da idade dos animais no momento do desafio limitando o tempo para imunizações. A padronização do desafio com leptospiras constitui etapa fundamental para a análise da capacidade protetora dos antígenos estudados, assim como a ação adjuvante das salmonelas recombinantes. Nossos ensaios abordaram vários aspectos necessários para a padronização dos ensaios de desafio. As proteínas Lip32, LigA e ankB induziram altos títulos de IgG e mostraram-se interessantes candidatas vacinais. A proteína LIC10191 apresentada por salmonelas induziu proteção parcial em hamsters. Os ensaios para medir a capacidade imunoprotetora desses antígenos serão repetidos, considerando os critérios para padronização elaborados neste trabalho.

Palavras-chave: Desenvolvimento de vacinas. Leptospirose. Leptospira interrogans. Salmonela vacinal recombinante SL3261. soxRS. 


\begin{abstract}
NAKAJIMA E. Investigation of proteins vaccine candidates against leptospirosis. Antigens presentation as purified recombinant proteins or as live vaccines by attenuated salmonelas. 2010. 178 f. Ph. D. Thesis (Biotechnology) - Interunidades em Biotecnologia, USP/Instituto Butantan/IPT, São Paulo, 2010.
\end{abstract}

Leptospirosis is a disease of global importance that affects humans and animals, caused by bacteria of the genus Leptospira. In Brasil, about three thousands human cases are notified every year and $10 \%$ of the patients die. Leptospirosis is a serious issue, especially in urban centers, due to the amount of rodents that are reservoirs of leptospira. The best way to control leptospirosis is prevention with better sanitation measures and public awareness. The project for sequencing the genome of Leptospira interrogans serovar Copenhageni, coordinated by a group of researchers from Instituto Butantan and the Funtional genome for vaccine development, in which our work belong, were encouraged by the need of an effective vaccine for humans. Besides the studies using recombinant proteins, we aprouched also the strategy of using salmonella vaccines to present the antigens expressed in vivo. After analysis of the genome of Leptospira interrogans serovar Copenhageni using bioinformatic tools, we selected and amplified ten genes, LIC10191, LIC10793, LIC12302, LIC11227, LIC13101, LIC12033, LIC12659, LIC10537, LIC10508 and LIC10868. We had focused our study on six antigens, encoded by six first genes listed above, besides the antigens Lip32 (LIC11352) and LigA (LIC10465). The genes were cloned into pAE and pAEsox vectors. The proteins were expressed in vitro in E. coli and purified by IMAC. We constructed plasmids carrying two genes and we tested the salmonella ability to express the two heterologous antigens simultaneously in vivo. The proteins LIC10191 and LIC10793 were used as purified proteins or expressed by recombinant salmonellas (SLLIC10191 and SLLIC10793) for immunization of mice. Recombinant salmonellas administered by intraperitoneal route induced higher immune response against the antigens comparing with the administration by oral and intranasal routes. The immune response of specific IgG using purified antigens was always higher than to the antigens presented by salmonellas An important result was the parcial protection of hamsters immunized with SLLIC10191 and challenged with Leptospira interrogans serovar Pomona. In other experiment, we observed that immunization with salmonellas induced antibodies against two antigens expressed simultaneously in vivo. In this assay there was no protection of immunized hamsters and challenged with Leptospira interrogans serovar 
Copenhageni. The immunization and challenge assays with Leptospira interrogans serovar Copenhageni assays were not conclusive. This serovar showed significant differences comparing with serovar Pomona, resulting more difficult its manipulation and the dose adjustments for challenge assays. Some issues were considerated and investigated, as the variability of leptospira virulence during culture in vitro and the difficulty on accurately counting the bacteria to be inoculated per animal, besides the intrinsic difficulties in the challenge assay, such as the interference of the age of the animals at the challenge, limiting the immunization period. The standardization of the challenge assay with leptospiras is an important step for the analysis of the immune protective capacity of the antigens, as well as the adjuvant ability of the recombinant salmonellas. In our assays we approach some important aspects for standardization of the challenge assays. The proteins Lip32, LigA and ankB induced high IgG titers and showed to be interesting vaccine candidates. The protein LIC10191 presented by salmonella induced partial protection in hamsters. The assays to properly measure the immune protective capacity of these antigens are going to be repeated considering the criteria for standardization established in this work.

Key words: Vaccine. Leptospirosis. Leptospira interrogans. Recombinant salmonella vaccine SL3261. soxRS. 


\section{LISTA DE ILUSTRAÇÕES}

Figura 1 - Distribuição de casos de leptospirose por município no Brasil, de 2007 a 2008...................28

Figura 2 - Número de casos confirmados de leptospirose no Brasil em 2009.......................................28

Figura 3 - Eletro micrografia da bactéria Leptospira interrogans, causadora da leptospirose..............30

Figura 4 - Desenho esquemático da estrutura da membrana celular e parede da salmonela...............36

Figura 5 - Esquema do sistema controlador do regulon soxRS e sua utilização para controle de expressão de genes heterólogos...................................................................................................................................39

Figura 6 - Vetor de expressão pAE e esquema da inserção do locus soxRS............................................47

Figura 7 - Modelo esquemático da área de contagem de bactérias na câmara de Petroff-Hausser...61

Figura 8 - Esquema da localização do motivo OmpA encontrado na proteína LIC10191....................66

Figura 9 - Esquema da localização do motivo peptidase_M22 encontrado na proteína LIC12302....68

Figura 10 - Esquema da localização dos motivos alfa integrina encontrados na proteína

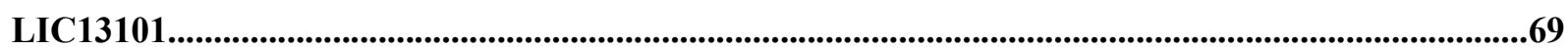

Figura 11 - Esquema da localização dos motivos TPR encontrados na proteína LIC10325.................70

Figura 12 - Esquema da localização dos motivos BID encontrado na proteína LIC10465...................70

Figura 13 - Esquema da localização dos motivos ank encontrado na proteína LIC12033....................71

Figura 14 - Análise dos produtos das amplificações gênicas por PCR em gel de agarose.....................72

Figura 15 - Análise dos clones com genes de leptospira em vetor pGEM-T Easy por digestão com

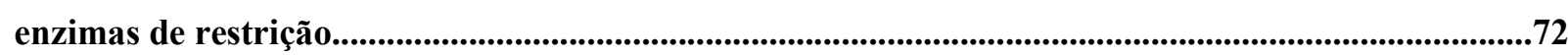

Figura 16 - Análise dos clones plasmidiais por digestão com as enzimas de restrição BamHI e HindIII. . .75

Figura 17 - Análise das digestões dos plasmidios pAELIC10325, pDestLIC11352 e pAEsox com enzimas de restrição, em gel de agarose......................................................................................................76

Figura 18 - Análise das construções plasmidiais pAEsoxLIC10325 e pAEsoxLIC11352, por digestão com enzimas de restrição. .76

Figura 19 - Análise dos fragmentos de DNA gene LigA, vetor pAEsox digerido e construção

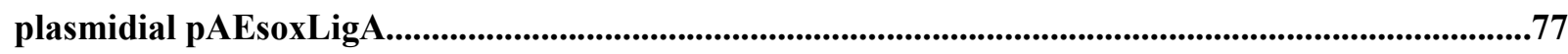

Figura 20 - Esquema da construção do plasmídeo híbrido pAEsoxLIC10191_psoxSLIC10793........79

Figura 21 - Análise da construção dos plasmídios híbridos por digestão enzimática.............................80

Figura 22 - Análise da expressão das proteínas recombinantes LIC10325 e LIC11352 em vetor

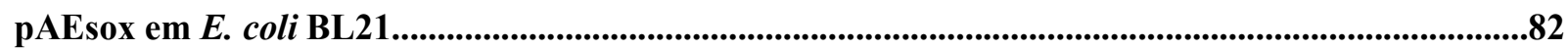

Figura 23 - Análise da expressão das proteínas recombinantes LIC10191 e LIC10793 em E. coli B121. 
Figura 24 - Análise da expressão das proteínas recombinantes LIC12302 e LIC11227 em E. coli

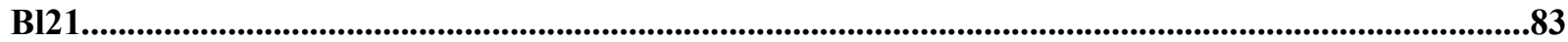

Figura 25 - Análise da expressão da proteína LIC13101 recombinante em E. coli Bl21......................83

Figura 26 - Análise da expressão em E.coli das proteínas recombinantes nos clones com vetores híbridos LIC10191_LIC10793 e LIC10191_LIC10537.......................................................................84

Figura 27 - Análise da expressão da proteína recombinante LIC10793 em salmonela SL3261 in

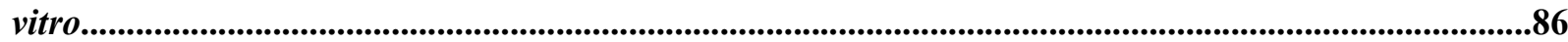

Figura 28 - Análise da expressão da proteína LIC10191, LIC11227, LIC13101 e LIC10325 em salmonela SL3261 in vitro por SDS PAGE. . .86

Figura 29 - Análise da expressão da proteína recombinante LigA em salmonela

SL3261pAEsoxLigA, por western blot. . .87

Figura 30 - Análise da expressão das proteínas recombinantes em salmonelas com vetores híbridos pAEsoxLIC10191_LIC10793 e pAEsoxLIC10191_LIC10537.....................................................................89

Figura 31 - Análise da expressão das proteínas LIC10191 e LIC10793 nos extratos solúveis de salmonela. .89

Figura 32 - Análise da expressão das proteínas recombinantes LIC10191 e LIC11352 (Lip32) em salmonela SL3261 por western blot. . .90 Figura 33 - Análise da purificação por IMAC das proteínas LIC10191 e LIC10793 por SDSPAGE . .93

Figura 34 - Análise da integridade das estruturas secundárias da proteína recombinante LIC10191 purificada.

Figura 35 - Análise da purificação por IMAC das proteínas LIC11227 e LIC12302 por SDS-

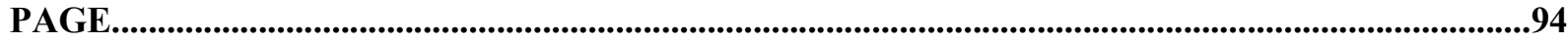

Figura 36 - Análise da purificação por IMAC da LIC12033 (ankB) por SDS-PAGE...........................94

Figura 37 - Reconhecimento das proteínas recombinantes por anticorpos IgG do soro de um paciente de leptospirose. .98

Figura 38 - Reconhecimento das proteínas recombinantes por anticorpos IgM do soro de um paciente de leptospirose..............................................................................................................................99

Figura 39 - Análise de IgG anti-LIC10191 no soro de camundongos imunizados................................104

Figura 40 - Análise de IgG anti-LIC10793 no soro de camundongos imunizados...............................105 Figura 41 - Análise de anticorpos específicos nos soros de camundongos imunizados com as proteínas LIC10191 e LIC10793 ou com as salmonelas SLLIC10191 e SLLIC10793, por western blot .107 
Figura 42 - IgG anti-LIC10191 no soro dos camundongos imunizados com proteínas purificadas e com salmonelas recombinantes SLLIC10191, SLLIC10191_LIC10537. 110

Figura 43 - Análise por western blot, do soro de camundongos imunizados com SLLIC10191_LIC10793, SLLIC10191 e SLLIC10793.

Figura 44 - Curva de freqüência de mortes dos hamsters inoculados com diferentes doses de Leptospira interrogans sorovar Pomona durante 21 dias após o inoculo

Figura 45 - Frequência de mortes dos hamsters imunizados com proteínas e salmonela recombinantes e desafio com Leptospira interrogans sorovar Pomona. .115

Figura 46 - IgG anti-LIC10191 nos soros dos hamsters imunizados com proteína LIC10191 ou com salmonela SLLIC10191 117

Figura 47 - Anticorpos IgG anti-LIC10793 no soro dos hamsters imunizados com o "pool" de três proteínas LIC10793, LIC12631 e LIC10659. 119

Figura 48 - Reconhecimento das proteínas LIC10191 e LIC10793 por anticorpos dos soros de animais dos grupos controle antes e depois do desafio com Leptospira interrogans sorovar Pomona .122

Figura 49 - Reconhecimento das proteínas recombinantes LIC10191 e LIC10793 por anticorpos dos soros de animais imunizados. . .123

Figura 50 - Frequência de morte dos animais inoculados com diferentes doses de Leptospira interrogans sorovar Copenhageni de segunda passagem.

Figura 51 - Frequência de morte dos animais inoculados com Leptospira interrogans sorovar Copenhageni de primeira passagem. .0128

Figura 52 - Frequência de mortes dos animais inoculados com diferentes doses de Leptospira interrogans sorovar Copenhageni de primeira passagem .131

Figura 53 - Frequência de morte dos animais imunizados e desafiados com Leptospira interrogans sorovar Copenhageni.

Figura 54 - Análise de IgG anti-LIC10191 e anti-LIC10793 nos soros dos hamsters imunizados com salmonelas recombinantes . .135

Figura 55 - Análise de IgG anti-LIC10191 e anti-LIC10793 nos soros dos hamsters imunizados com proteínas purificadas.

Figura 56 - Análise de IgG anti-LIC10191 dos hamsters imunizados com proteína LIC10191 purificada ou SLLIC10191

Figura 57 - Análise de IgG anti-LIC10191 ns soros dos hamsters imunizados com as proteínas LIC10191 e Lip32 purificadas e com SLLIC10191_Lip32. 
Figura 58 - Análise de IgG anti-LIC10191 nos soros dos hamsters imunizados com SLLIC10191 e reforço com proteína LIC10191 purificada ou imunizados com SLLIC10191 mais LigA

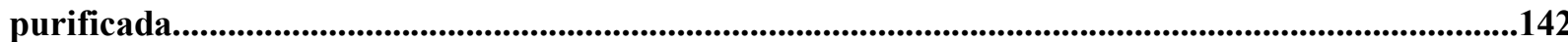

Figura 59 - Análise de IgG anti-Lip32 nos soros dos hamsters imunizados com proteína Lip32 purificada ou com SLLip32.

Figura 60 - Análise de IgG anti-Lip32 nos soros dos hamsters imunizados com as proteínas LIC10191 e Lip32 purificadas ou com SLLIC10191_Lip32 .143

Figura 61 - Análise de IgG anti-LigA nos soros dos hamsters imunizados com proteína LigA purificada ou com SLLigA.

Figura 62 - Análise de IgG anti-ankB nos soros dos hamsters imunizados com proteína AnkB purificada ou com SLankB. 144

Figura 63 - Análise do reconhecimento de proteínas recombinantes purificadas pelo soro de animais dos grupos controle .147

Figura 64 - Análise do reconhecimento das proteínas recombinantes purificadas pelo soro de animais dos grupos imunizados com as proteínas purificadas LIC10191, Lip32, ankB e LigA e com as salmonelas recombinantes. 148 Figura 65 - Análise do reconhecimento das proteínas recombinantes purificadas pelo soro de animais dos grupos imunizados com as proteínas purificadas LIC10191 e Lip21, SLLIC10191_Lip32 e a SLLIC10191 com LigA ou reforço de proteína .149 


\section{LISTA DE TABELAS}

Tabela 1 - Oligonucleotídeos iniciadores utilizados para a amplificação gênica por PCR, tamanho dos fragmentos gênicos e massa molecular esperada para as proteínas 45

Tabela 2 - Oligonucleotídeos utilizados nos seqüenciamentos. .52

Tabela 3 - Proteínas recombinantes utilizadas nos testes de western blot suas massas moleculares, intensidade do reconhecimento por anticorpos do soro de paciente de leptospirose. .96

Tabela 4 - Doses de salmonela administradas nos camundongos e recuperação das bactérias do baço após 12 dias da inoculação.

Tabela 5 - Grupos de camundongos imunizados para obtenção de anticorpos e análise da resposta a salmonelas recombinantes 102

Tabela 6 - Intensidade relativa das bandas de reconhecimento de IgG contra as proteínas LIC10191 e LIC10793 purificadas. Avaliação dos resultados da Figura 41. .106

Tabela 7 - Grupos de imunização e doses administradas em ensaio de imunização com salmonela com vetores híbridos. .108

Tabela 8 - Grupos de imunização de hamsters e doses administradas via intraperitoneal. . .113

Tabela 9 - Sobrevivência de hamsters imunizados ao desafio com leptospiras. Resultado do teste de isolamento de leptospiras dos rins dos animais sobreviventes. 116

Tabela 10 - Intensidade relativa do reconhecimento de LIC10191 e LIC10793 por IgG específicos no soro dos animais imunizados antes e depois do desafio. Avaliação das Figuras 48 e 49.

Tabela 11 - Dose de leptospiras no teste preliminar de desafio segundo as contagens em lâmina ou câmara de Petroff-Hausser e sobrevivência dos animais por 21 dias após a infecção.

Tabela 12 - Grupos de imunização de hamsters e doses administradas via intraperitoneal 130

Tabela 13 - Contagem das leptospiras em lâmina e câmara de Petroff-Hausser, doses do desafio e sobrevivencia dos animais

Tabela 14 - Grupos de imunização de hamsters e doses administradas via intraperitoneal para o desafio com Leptospira interrogans sorovar Copenhageni

Tabela 15 - Intensidade relativa do reconhecimento das proteínas LIC10191, Lip32, LigA e ankB no soro dos hamsters imunizados. Avaliação das Figuras 64 e 65. 


\section{LISTA DE ABREVIATURAS E SIGLAS}

6xHis - códons ligados aos genes de interesse que codificam seis histidinas

Abs - absorbância

amp - ampicilina

$\mathbf{a m p R}$ - presença de gene que confere resistência à ampicilina

Ank - proteína com domínios anquirina

ATG - códon de iniciação (metionina)

BamHI - endonuclease de restrição I de Bacillus amyloliquefaciens $\mathrm{H}$

BCG - Bacilo Calmette-Guerin

BLAST - Basic local alignment search tool

BSA - soro albumina bovina

DAB - tetrahidrocloridrato de 3,3'-diaminobenzidina

ddNTP - didesoxirribonucleotídeo

DNA - ácido desoxirribonucléico

dNTP - desoxirribonucleotídeo

DO - densidade óptica

E. coli-Escherichia coli

EcoRI - endonuclease de restrição I de Escherichia coli

EDTA - ácido etileno diamino tetra-acético

ELISA - enzyme linked immunosorbent assay

EMJH - Ellinghausen McCullough Johnson Harris (meio de cultura para leptospiras)

FC - fragmento C da toxina tetânica

$\mathbf{H}_{2} \mathbf{O}_{2}$ - peróxido de hidrogênio

HCl - ácido clorídrico

HindIII - endonuclease de restrição III de Haemophilus influenzae Rc

IFN- $\gamma$ - interferon gama

IgG, IgM e IgA - imunoglobulinas G, M e A

IL - interleucina

IMAC - cromatografia de afinidade a metal (Imobilized metal affinity chromatography)

In - via intranasal

Ip - via intraperitoneal

IPTG - isopropil-b-D-tiogalactopiranosídeo

kDa - kilo Dalton 
$\mathbf{L}-$ litro

lac $\mathbf{Z}$ - promotor da beta-galactosidase

LIC - Leptospira interrogans sorovar Copenhageni (referência aos genes e às proteinas)

Lig - proteína de leptospira Ig-like (leptospiral Ig-like protein)

LipL - lipoproteína de leptospira

LP - lipoproteína

LPS - lipopolissacarídeo

M - molar

MAT - teste de aglutinação microscópica

MPLA - monofosforil lipídeo A

MS - Ministério da Saúde

NaCl - cloreto de sódio

$\mathbf{N a O H}$ - hidróxido de sódio

NCBI - National Center for Biotechnology Information

NdeI - endonuclease de restrição I de Neisseria denitrificans

NO - óxido nítrico

novo - antibiótico novobiocina

NruI - endonuclease de restrição I de Nocardia rubra

${ }^{\circ} \mathbf{C}$ - graus Celcius

O2 - ânion superóxido

Omp - proteína de membrana externa

OMS - Organização Mundial da Saúde

OPD - o-dihidrocloreto de felilenodiamina

$\mathbf{p b}$ - pares de bases

PBS - salina tamponada com fosfato

PCR - reação em cadeia da polimerase (polimerase chain reaction)

PIPES - piperazina-N,N'-bis (ácido 2-etanosulfônico)

PQ - paraquat

psi - libras por polegada quadrada (pound force per square inch)

PSORT - Protein subcelular localization prediction

PstI - endonuclease de restrição I de Providencia stuartii

PVDF - difluoreto de polivinilideno

RBS - sítio de ligação do ribossomo (ribossome binding site)

RNA - ácido ribonucleico 
SDS - duodecil sulfato de sódio

SDS-PAGE - eletroforese em gel de poliacrilamida contendo SDS

SL - salmonela

SMART - Simple modular architecture research tool

SMC - sítio de múltiplas clonagens

SoxR - proteína SoxR inativa

SoxR@ - proteína SoxR ativa

soxRpsoxS - lócus com gene soxR e promotor de soxS

Sph - esfingomielinase

T7 - promotor do fago $\mathrm{T} 7$

TAE - tampão Tris-acetato-EDTA

TEMED - N,N, $\mathrm{N}^{\prime}, \mathrm{N}^{\prime}$ - tetrametiletilenodiamina

Th1 - células T auxiliadoras tipo 1 (T helper 1)

Th2 - células T auxiliadoras tipo 2 (T helper 2)

TLR4 - Toll Like Receptor 4

Tris - (hidroxidometil) amino-metano

UV - ultravioleta

V - volts

Vap - virulence associated protein

Vo - via oral

$\boldsymbol{X b a I}$ - endonuclease de restrição I de Xhantomonas badrii

XGal - 5-bromo-4-cloro-3-indolil-b-D-galactopiranosídeo

XhoI - endonuclease de restrição I de Xhantomonas holcicola

$\boldsymbol{\mu g}$ - micrograma

$\boldsymbol{\mu} \mathbf{L}-$ microlitro

$\boldsymbol{\mu m}$ - micrometro 


\section{SUMÁRIO}

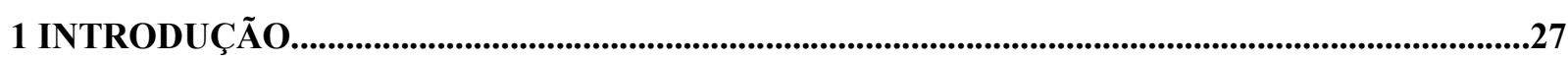

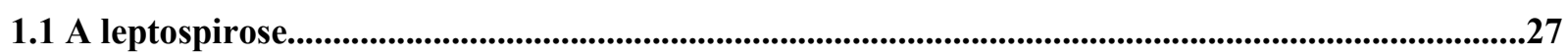

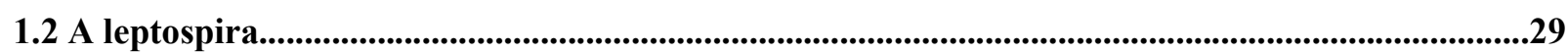

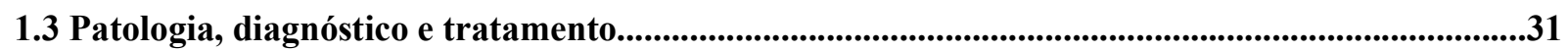

1.4 Desenvolvimento de vacinas contra leptospirose.................................................................................32

1.5 Salmonelas vacinais recombinantes..............................................................................................................35

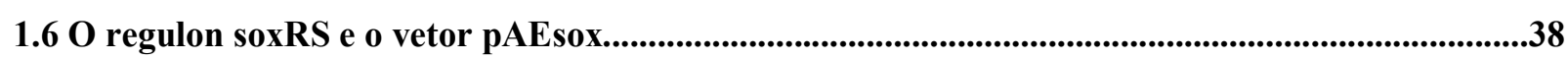

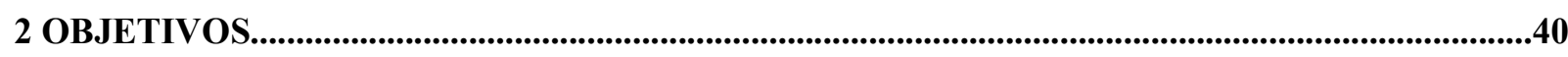

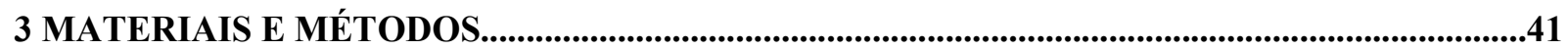

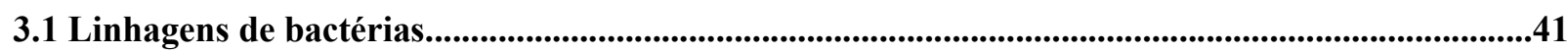

3.2 Preparo de bactéria competente e transformação...................................................................................41

3.2.1 Meios de cultura para crescimento de bactérias.............................................................................41

3.2.2 Materiais e soluções para preparo de bactéria competente......................................................................42

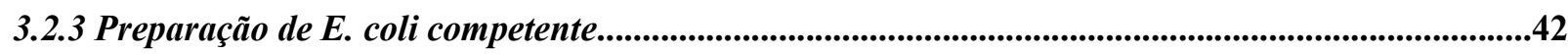

3.2.4 Preparação de salmonella competente................................................................................................43

3.2.5 Transformação de bactéria competente por choque térmico....................................................................43

3.2.6 Materiais e soluções para transformação de bactéria competente.........................................................43

3.2.7 Procedimento para transformação de bactéria competente.................................................................43

3.3 Amplificação dos genes por PCR e inserção nos vetores de expressão..............................................44

3.3.1 Escolha dos genes e desenho de primers (programas utilizados)..........................................................44

3.3.2 Materiais e soluções para reação de polimerização em cadeia (PCR)................................................45

3.3.3 Vetores utilizados.......................................................................................................................................................46

3.3.4 Clonagem dos genes nos vetores de expressão........................................................................48

3.4 Eletroforese em gel de agarose para análise de fragmentos gênicos...................................................49

3.4.1 Materiais e soluções para eletroforese em gel de agarose......................................................................49

3.4.2 Procedimento para eletroforese em gel de agarose.................................................................................50

3.5 Método fenol:clorofórmio para análise da presença de inserto em vetores clonados.......................50

3.5.1 Materiais e soluções para teste de fenol-clorofórmio.................................................................50

3.5.2 Procedimento para teste de fenol-clorofórmio.................................................................................50

3.6 Seqüenciamento de DNA............................................................................................................................51

3.7 Expressão das proteínas recombinantes em E. coli................................................................................52

3.7.1 Materiais e soluções para expressão de proteínas.........................................................................................52 
3.7.2 Procedimento para preservação dos clones e teste de expressão de proteínas recombinantes em $E$.

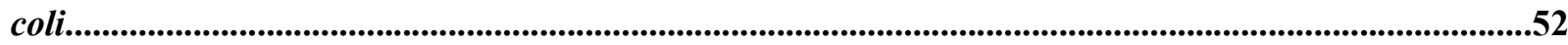

3.8 Expressão das proteínas recombinantes em salmonela.............................................................................53

3.9 Dosagem de proteína pelo método de Bradford..........................................................................................54

3.9.1 Materiais e soluções para dosagem de proteína.........................................................................................54

3.9.2 Procedimento para dosagem de proteína......................................................................................................54

3.10 Eletroforese em gel de poliacrilamida (SDS-PAGE)....................................................................54

3.10.1 Materiais e soluções para SDS PAGE...........................................................................................55

3.10.2 Procedimento para SDS PAGE .............................................................................................................55

3.11 Purificação das proteínas recombinantes....................................................................................................56

3.11.1 Materiais e soluç̃̃es para purificação das proteínas............................................................................56

3.11.2 Procedimento para purificação das proteínas por IMAC .......................................................................56

3.12 Dicroísmo circular para análise da estrutura secundária da proteína LIC10191..........................58

3.13 Imunização de camundongos e obtenção de soro..........................................................................58

3.14 Teste de dose de salmonelas e recuperação de bactérias do baço de camundongos.......................59

3.15 Ensaios de imunização de hamsters e desafio com leptospiras virulentas.........................................59

3.16 ELISA para análise de resposta humoral em camundongos e hamsters imunizados....................62

3.16.1 Materiais e soluções para ELISA.................................................................................................................62

3.16.2 Procedimento para ELISA .........................................................................................................................63

3.17 Western blot para análise de reconhecimento do antígeno pelo soro............................................63

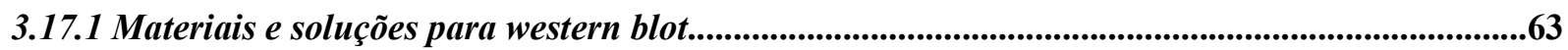

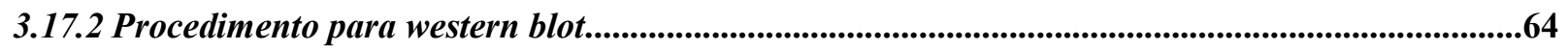

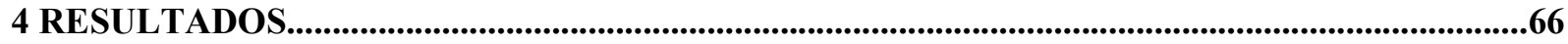

4.1 Caracterização dos antígenos selecionados.................................................................................................66

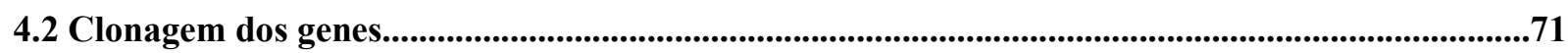

4.2.1 Amplificação dos genes e clonagem em vetor pGEMT-Easy.......................................................71

4.2.2 Clonagem dos genes de leptospira nos vetores $\mathrm{pAE}$ e pAEsox.............................................................73

4.2.3 Construção de vetores híbridos....................................................................................................................77

4.3 Expressão das proteínas recombinantes em $E$. coli.......................................................................80

4.3.1 Expressão das proteínas recombinantes isoladas em E. coli..........................................................80

4.3.2 Expressão das proteínas nos clones de E. coli com os vetores hibridos...........................................84

4.4 Clonagem e expressão de proteínas em Salmonella...................................................................................85

4.4.1 Expressão das proteínas isoladas em salmonela.............................................................................85

4.4.2 Expressão das proteínas nos clones de salmonela com os vetores híbridos.........................................88 
4.5 Purificação das proteínas recombinantes

4.6 Reconhecimento dos antígenos purificados por anticorpos IgG e IgM do soro de paciente de

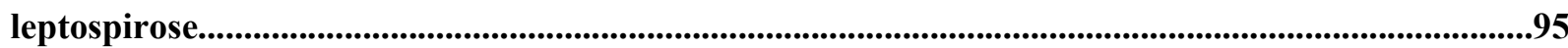

4.7 Persistência das salmonelas no hospedeiro, toxicidade a apresentação de antígenos......................100 4.8 Ensaios de imunização em camundongos para obtenção de soros contra as proteínas recombinantes e avaliação da imunização com salmonelas recombinantes.

4.8.1 Imunização de camundongos com as proteínas LIC10191 e LIC10793 e as salmonelas SLLIC10191 e SLLIC10793 via ip, in e vo .101

4.8.1.1 Determinação de anticorpos IgG no soro dos camundongos imunizados por ELISA. 102 4.8.1.2 Avaliação do reconhecimento dos antígenos por anticorpos específicos dos soros de animais imunizados, por western blot. .106

4.8.2 Ensaio de imunização de camundongos com as salmonelas carregando vetores híbridos............108 4.8.2.1 Determinação de anticorpos IgG no soro dos camundongos imunizados, por ELISA...........109 4.8.2.2 Avaliação do reconhecimento dos antígenos por anticorpos específicos dos soros dos animais imunizados, por western blot.

4.9 Imunização de hamster para avaliar imuno proteção em ensaios de desafio com leptospiras virulentas.

4.9.1 Primeiro ensaio de imunização e desafio com Leptospira interrogans sorovar Pomona

4.9.1.1 Determinaç̃o de anticorpos IgG no soro dos animais imunizados, por ELISA . .116

4.9.1.2 Avaliacão do reconhecimento dos antígenos por anticorpos específicos dos soros dos animais imunizados por western blot. . .120

4.9.2 Estudos para desafio com Leptospira interrogans sorovar Copenhageni.. .125

4.9.2.1 Freqüência de morte dos hamsters infectados com diferentes doses de Leptospira interrogans sorovar Copenhageni com duas passagens em cultura. .126

4.9.2.2 Estudo da variaç̃o de susceptibilidade de hamsters machos ou fêmeas e a interferência do meio de cultura na infeccão por Leptospira interrogans sorovar Copenhageni. .127

4.9.3 Segundo ensaio de imunização e desafio com Leptospira interrogans sorovar Copenhageni......129

4.9.3.1 Determinação de anticorpos IgG no soro dos animais imunizados, por ELISA . .134

4.9.4 Terceiro ensaio de imunização e desafio com Leptospira interrogans sorovar Copenhageni.......137

4.9.4.1 Determinação de IgG no soro dos animais imunizados por ELISA. . .139

4.9.4.2 Avaliação do reconhecimento dos antígenos por anticorpos específicos dos soros dos animais imunizados por Western Blot .144 


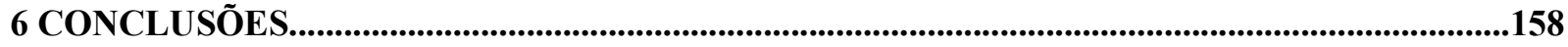

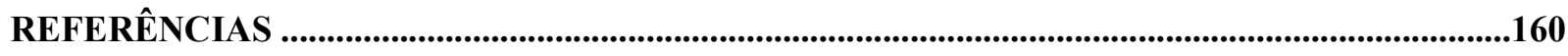

ANEXO A - Cálculo do valor da DL ${ }_{50}$ de $L$. interrogans sorovar Pomona baseado no modelo de Reed

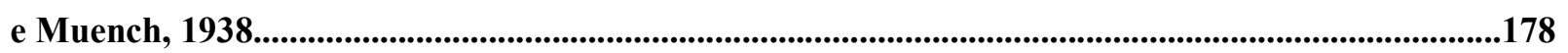




\section{INTRODUÇÃO}

\subsection{A leptospirose}

A leptospirose é uma zoonose causada por diferentes linhagens de bactérias espiroquetas do gênero Leptospira. Roedores são reservatórios das leptospiras, pois se adaptam e não morrem em decorrência da infecção. Sua urina e o tecido renal com pH alcalino são favoráveis para a sobrevivência do microrganismo, permitindo a colonização e eliminação permanente pela urina (SILVA, 1998).

Nos últimos anos a leptospirose tem sido considerada uma das doenças infecciosas emergentes de importância global (BHARTI et al., 2003). A leptospirose também está entre as doenças negligenciadas por ser um grave problema em países em desenvolvimento (HOTEZ e FERRIS, 2006). O crescimento urbano descontrolado, a falta de saneamento básico e o acúmulo de lixo favorecem a proliferação dos roedores, os principais responsáveis pela transmissão da doença ao homem. O impacto causado pelas doenças negligenciadas é medido pelo número de anos perdidos por causa de morte prematura ou incapacidade física (DALY “disability-adjusted life year") (HOTEZ e FERRIS, 2006). De fato, pacientes com leptospirose necessitam de dias de repouso a internações em UTIs com auxílio de aparelhos de hemodiálise, sendo privado do convívio familiar e perdendo dias de trabalho. Nos países desenvolvidos, a doença está principalmente relacionada com atividades de lazer e esportivas ao ar livre, como natação, canoagem e pesca, e também atividades de risco ocupacional, como lixeiros, trabalhadores de esgoto, criadores de peixe, rizicultores e cortadores de cana (LEVETT, 2001; MORGAN et al., 2002; HAAKE et al., 2002).

No Brasil, a leptospirose é endêmica em todas as regiões (Figura 1). Segundo dados divulgados pelo Ministério da Saúde, são diagnosticados em média três mil casos por ano e cerca de $10 \%$ dos pacientes morrem. Esporadicamente ocorrem surtos epidêmicos, como em 1996 quando foram confirmados 5579 casos, em 2009 foram 3755 casos e 331 pacientes chegaram ao óbito. Devido à dificuldade do diagnóstico, muitos casos não são notificados, o que interfere nos dados estatísticos. Os casos da doença aumentam significativamente durante os períodos de chuvas, principalmente nas regiões sul e sudeste, isso porque a urina dos roedores se mistura com a água das enchentes, contaminando a população exposta (Figura 2). Ainda segundo dados do Ministério da Saúde, quase $80 \%$ dos pacientes são do sexo masculino e a maior incidência está na área urbana. 


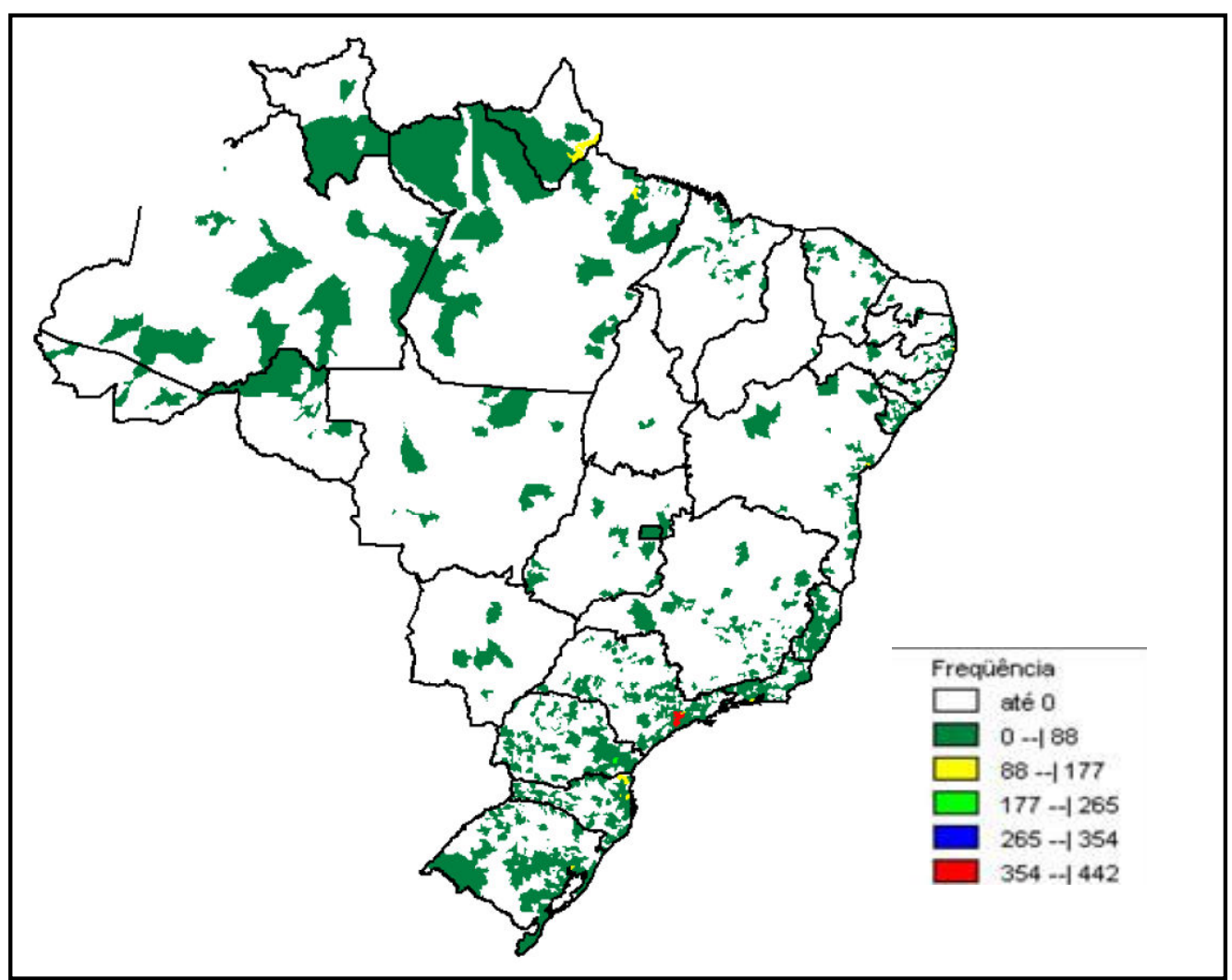

Figura 1 - Distribuição de casos de leptospirose por município no Brasil, de 2007 a 2008 . A leptospirose é endêmica em todo país com maior incidência nas regiões sul e sudeste. FONTE: Ministério da Saúde. Secretaria de Vigilância em Saúde, 2009.

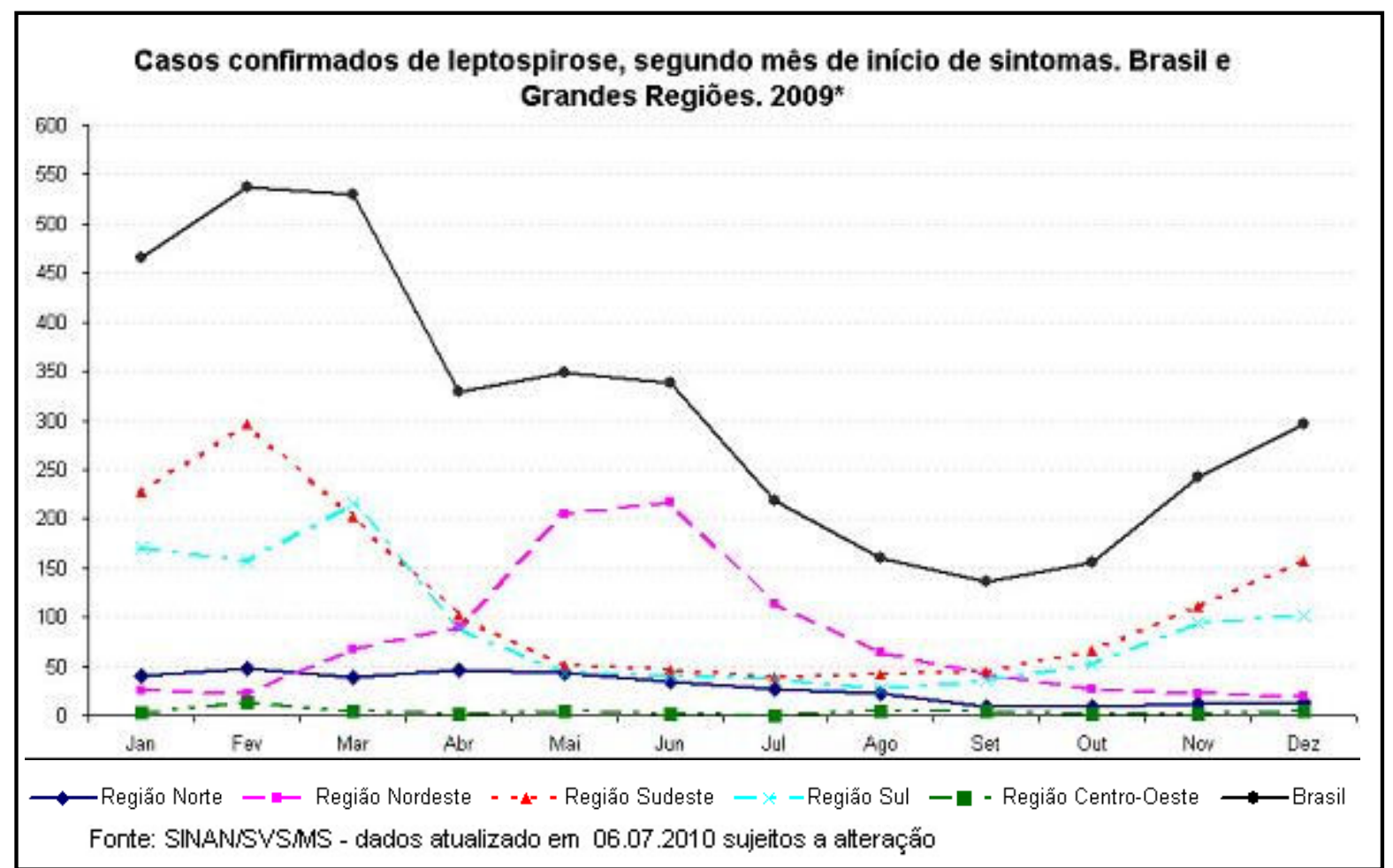

Figura 2 - Número de casos confirmados de leptospirose no Brasil em 2009. O número de casos aumenta nas regiões sul e sudeste nos meses de dezembro a março, e na região nordeste entre os meses de abril e julho. Esses períodos são caracterizados por fortes chuvas.

FONTE: Ministério da Saúde, Secretaria de Vigilânicia em Saúde, 2010. 
A leptospirose animal também gera um problema sério de ordem econômica, por causar perda de produtividade do gado, diminuição na produção de leite e abortos, diminuição de engorda de suínos. Os animais domésticos, como os cachorros, também são infectados pela bactéria e podem morrer em decorrência da infecção. Esses animais ainda aumentam a contaminação dos ambientes liberando as leptospiras pela urina.

As autoridades em Saúde Pública, como a Agência Nacional de Vigilância Sanitária (Anvisa), fazem campanhas de prevenção contra a leptospirose. Algumas medidas preventivas consistem em evitar o contato com a água ou lama de enchentes, contenção e destino adequado do lixo, uso de botas e luvas ao manusear entulhos e desentupir esgotos e a vacinação periódica de animais domésticos. Além disso, são necessárias medidas ligadas ao meio ambiente, tais como obras de saneamento básico (abastecimento de água, coleta de lixo e esgoto), desinfecção de reservatórios de água, melhorias nas habitações humanas e o combate a proliferação dos ratos. No entanto, esses trabalhos de conscientização da população e melhoria da condição ambiental são de longo prazo e não dispensam medidas de prevenção como a utilização desenvolvimento de testes de diagnóstico rápido e de vacinas.

\subsection{A leptospira}

Os agentes causadores de leptospirose são bactérias espiroquetas do gênero Leptospira, pertencente à família Leptospiraceae, ordem Spirochaetales (FAINE et al., 1999). As leptospiras são aeróbias obrigatórias, helicoidais flexíveis e móveis, possuem aproximadamente $0,1 \mu \mathrm{m}$ de diâmetro e 6 a $20 \mu \mathrm{m}$ de comprimento e apresentando uma ou ambas extremidades em forma de gancho (FAINE et al., 1999). Devido a sua forma, as leptospiras não podem ser vistas ao microscópio óptico comum, apenas em microscópio de campo escuro ou contraste de fase, e não são coradas pela técnica de Gram. A estrutura da bactéria pode ser descrita por seus componentes: - uma membrana externa que cerca a parede celular, o complexo peptideoglicano; - um flagelo, denominado filamento axial ou endoflagelo, que se encontra entre a parede celular e a membrana externa e - a membrana interna contendo várias estruturas internas, incluindo o DNA (FAINE et al., 1999). Este gênero de bactéria é subdividido em muitas espécies, dentre as quais oito são patogênicas. Subgrupos são determinados de acordo com os sorovares, sendo que existem mais de duzentos sorovares patogênicos (FARR, 1995; FAINE et al., 1999). A classificação dos diferentes sorovares é baseada na antigenicidade do LPS (lipopolissacarídeo) da membrana da bactéria (LEVETT, 2001). A temperatura ótima para o crescimento da bactéria está entre 28 
${ }^{\circ} \mathrm{C}$ e $30{ }^{\circ} \mathrm{C}$, e o tempo de geração é de aproximadamente 6-8 horas (FAINE et al., 1999). Quando livres no meio ambiente, sobrevivem por um longo período de tempo em solo úmido com $\mathrm{pH}$ entre 7 e 8 (CHANG, 1948). As leptospiras podem ser cultivadas in vitro, porém, necessitam de meios de cultura especiais, sendo os mais utilizados o EllinghausenMcCullough-Johnson-Harris (EMJH) e o meio semi-sólido Fletcher, enriquecidos com soro de coelho ou albumina bovina (ADLER et al., 1986).

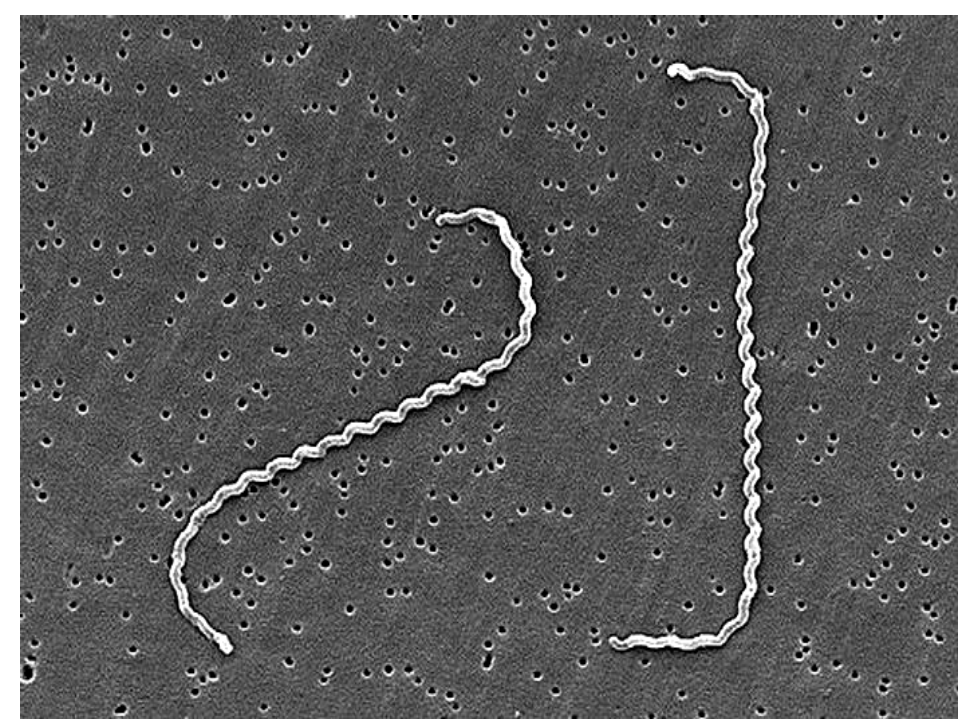

Figura 3 - Eletro micrografia da bactéria Leptospira interrogans, causadora da leptospirose. FONTE: Weyant et al., 1999.

O genoma da leptospira consiste em dois cromossomos circulares (BOURSAUXEUDE et al., 1998). É um genoma grande comparado com os genomas de outras espiroquetas como treponema e borrelia, o que pode estar relacionado com a habilidade da leptospira se adaptar em diferentes ambientes, como no hospedeiro animal ou livre no meio (BHARTI et al., 2003). Até o momento, foram seqüenciados o genoma de quatro espécies de leptospiras patogênicas, Leptospira interrogans sorovar Lai e sorovar Copenhageni, duas linhagens de Leptospira borgpetersenii sorovar Hardjo-bovis, e duas linhagens de leptospira não patogênica, biflexa sorovar Patoc. Os genomas das duas leptospiras do gênero interrogans possuem aproximadamente 4,6 Mpb codificando cerca de 3700 genes no sorovar Copenhageni e 4700 genes no sorovar Lai (NASCIMENTO et al., 2004; REN et al., 2003). O genoma da Leptospira borgpetersenii sorovar Hardjo-bovis é menor com 3,9 Mpb codificando aproximadamente 2900 genes (LO et al., 2006) e o genoma da Leptospira biflexa sorovar Patoc possui 3,9 Mpb codificando 3600 genes. Além dos dois cromossomos, a biflexa possui um plasmídeo de $74 \mathrm{Kpb}$ que codifica 59 proteínas (PICARDEAU et al., 2008). 
Apesar das diferenças entre as três espécies, foram encontradas 2052 sequências codificadoras de proteínas comuns entre os genomas. Poucos genes são exclusivos em cada espécie e 656 genes são comuns apenas entre linhagens patogênicas (PICARDEAU et al., 2008).

A entrada da leptospira nos hospedeiros pode ocorrer por pequenas lesões e aberturas na epiderme. Essas bactérias possuem grande capacidade de atravessar os tecidos. Possivelmente, entram na corrente sanguínea ou linfática após atravessarem pela conjuntiva, pelo trato genital em alguns animais, pela mucosa nasofaringea ou pelos pulmões por inalação de aerossóis. Alcançam todos os órgãos e tecidos do organismo, porém, se localizam preferencialmente no fígado, rins, coração e músculo esquelético. Podem atravessar a placenta da mãe para o feto em qualquer estágio de gestação. A principal lesão causada pela leptospira ocorre nas paredes das pequenas veias sanguíneas, levando ao escape e ao extravasamento de células, podendo chegar a um quadro grave de hemorragia. Outras lesões são consideradas secundárias. Propriedades relevantes na patogenicidade da leptospira são: a invasão, a adesão à superfície celular, os fatores de colonização e a toxicidade (FAINE et al., 1999).

\subsection{Patologia, diagnóstico e tratamento}

A infecção por leptospiras pode ser assintomática ou pode gerar sintomas diversos, muitas vezes confundidos com outras doenças como gripe, dengue, febre tifóide, febre amarela, malária, hepatite, entre outras. Nos casos sintomáticos, mais de 90\% dos indivíduos apresentam a forma mais branda, enquanto que 5 a $10 \%$ dos pacientes apresentam a forma mais grave com sinais de icterícia (World Health Organization - WHO, 2003). O período de incubação da bactéria pode variar de 2 a 30 dias, sendo dividido em duas fases nem sempre bem evidentes. Na primeira fase, chamada bacteremia, ocorre a disseminação das bactérias no sangue e tem duração de 4 a 7 dias. Na segunda fase, chamada imune, há o aparecimento de anticorpos e as bactérias são eliminadas na urina. Essa fase dura entre 10 a 30 dias (PEREIRA, 2005). A doença pode ainda se manifestar de duas formas: a anictérica e a ictérica. A forma anictérica é caracterizada por febre alta contínua, calafrios, dores de cabeça, dores musculares e abdominais, diarréia, náuseas e vômitos. A forma ictérica, mais grave, também conhecida como síndrome de Weil, é caracterizada por icterícia, insuficiência renal, distúrbios hemorrágicos e alta mortalidade (FAINE et al., 1999; PEREIRA, 2005). Os sintomas da forma anictérica e do início da forma ictérica são comuns e facilmente confundidos com outras doenças, o que pode atrasar o diagnóstico e o tratamento. Além disso, muitas vezes o paciente é tratado apenas com antibióticos e a doença não é diagnosticada e, 
portanto, não notificada para os órgãos responsáveis que assim, publicam dados subestimados do número de casos.

O diagnóstico da doença deve ser confirmado por análise de presença de leptospiras, fragmentos de DNA ou detecção de anticorpos específicos por testes sorológicos. As leptospiras são geralmente isoladas a partir do sangue, liquor ou urina, e cultivadas in vitro em meio EMJH (Ellinghausen McCullough Johnson Harris). Porém, o crescimento in vitro é lento. Os resultados são obtidos de duas a quatro semanas e não acompanha a evolução da doença. Testes de PCR têm sido mais utilizados por serem mais sensíveis e assim o diagnóstico é feito nos primeiros dias de infecção, permitindo tratamento mais específico e eficaz (BROWN et al., 1995; CABALLERO et al., 1994; ZUERNER, 1995; OLIVEIRA et al., 2003, BAL et al., 1994; LEVETT et al., 2005). Anticorpos são detectáveis no sangue 5 a 7 dias após o início dos sintomas. Nesta fase os testes ELISA-IgM e micro-aglutinação (MAT) também podem ser utilizados. Os testes de ELISA-IgM são considerados mais apropriados e são mais acessíveis para laboratórios clínicos. O MAT é um teste quantitativo e mais complexo porque necessita da manutenção das cepas marcadoras. O diagnóstico diferencial deve considerar os dados epidemiológicos e clínicos.

O tratamento contra a leptospirose é feito com antibióticos, como penicilina $G$ cristalina, doxiciclina ou tetraciclina, e deve ser iniciado preferencialmente até o $5^{\circ}$ dia do início dos sintomas. Em paralelo com os antibióticos, existe a terapia de suporte que consiste na reposição hidroeletrolítica, na assistência cárdio respiratório, transfusão de sangue e derivados, nutrição enteral ou parental, proteção gástrica, entre outros (WHO, 2003). Estes tratamentos, além de custosos, muitas vezes requerem internação, privando o paciente do convívio familiar e social e causando perda de dias de trabalho.

Uma proposta óbvia na prevenção da leptospirose é a utilização de vacinas.

\subsection{Desenvolvimento de vacinas contra leptospirose}

Não existe ainda uma vacina contra leptospirose para uso em humanos, registrada no FDA (Food and drugs administration) ou na Agência de Vigilância Sanitária (ANVISA). Em alguns países existem vacinas disponíveis contra leptospirose, recomendadas apenas para pessoas em grupos de risco. A vacina cubana, vax-SPIRAL ${ }^{\circledR}$, é trivalente contra Leptospira interrogans sorovar Canicola, Leptospira interrogans sorovar Copenhageni e Leptospira interrogans sorovar Mozdok contendo células inteiras inativadas com formaldeído e adsorvidas em Alhydrogel. Na suspensão de 0,5 ml há 5-8 x $10^{9}$ células de cada sorovar 
(MARTINEZ et al., 1998; MARTINEZ et al., 2000). A vacina francesa, Spirolept ${ }^{\circledR}$, é composta por Leptospira interrogans Icterohaemorrhagiae. Cada dose da vacina é composta por $2 \times 10^{8}$ bactérias em $1 \mathrm{ml}$ de tampão. Deve ser administrada duas doses subcutâneas em intervalo de 15 dias, com revacinação após 4 a 6 meses e reforço a cada dois anos (RODRIGUEZ-GONZALES et al., 2004). Existe também uma vacina tetravalente disponível no Japão. A vacina é composta por bactérias inteiras mortas por formalina. Na suspensão há $2,5 \times 10^{8}$ das bactérias Leptospira interrogans sorovar Australis, Leptospira interrogans sorovar Autumnalis e Leptospira interrogans sorovar Hebdomadis e $5 \times 10^{8}$ da bactéria Leptospira interrogans sorovar Copenhageni. A vacina é administrada via subcutânea em duas doses, com intervalo de 7 dias e um reforço após 5 anos (KITAOKA e INOUE, 1952 apud KOIZUMI e WATANABE, 2005). Existem vacinas em desenvolvimento na Rússia e China (IKOEV et al., 1999; CHEN, 1985; YAN et al., 2003). As vacinas para uso humano são preparadas com sorovares predominantes em determinadas áreas e são utilizadas em grupos de alto risco. A proteção é de curta duração e são sorovares específicos, além de gerar efeitos colaterais indesejáveis.

As vacinas veterinárias, como por exemplo as para cães e bovinos, impedem que os animais adoeçam, mas não impedem a infecção e a transmissão para humanos (BOLIN e ALT, 2001; BHARTI et al., 2003). São geralmente preparadas na forma de bacterinas, ou seja, utilizando células inteiras mortas por calor ou formol, e são baseadas na resposta imune ao LPS da bactéria. Há a necessidade de revacinação a cada seis meses.

Uma boa vacina deve contemplar aspectos de proteção prolongada, de cobertura contra várias espécies do patógeno, não causar efeitos colaterais e ainda ter baixo custo de produção, uma vez que se destina principalmente a populações de baixa renda e teria que ser financiada pelo governo. As vacinas protéicas são supostamente mais apropriadas para corresponder a esses aspectos.

Com o sequenciamento de genomas bacterianos inteiros, foi proposta uma nova forma de busca direcionada de antígenos vacinais, a "vaccinologia reversa" (RAPPUOLI, 2000). Essa metodologia foi inicialmente utilizada na investigação de vacinas contra as bactérias Neisseria meningitidis, sorogupo B (TETTELIN et al., 2000; PIZZA et al., 2000), Streptococcus pneumoniae (WIZEMANN et al., 2001) e Mycobacterium tuberculosis (COLE et al., 1998; DOHERTY e ANDERSEN, 2000) e tem sido usada, mais recentemente, na busca de antígenos vacinais contra o parasita Schistosoma mansoni (VERJOVSKI-ALMEIDA et al., 2003). 
O genoma da Leptospira interrogans sorovar Copenhageni foi sequenciado (NASCIMENTO et al., 2004) e anotado utilizando-se várias ferramentas de bioinformática. As proteínas preditas foram classificadas de acordo com a provável função por comparação com outras proteínas dos bancos de dados. Essas informações podem ser acessados na página da Internet Leptospira interrogans sorovar Copenhageni Genome Project.

A análise dos dados do genoma possibilitou selecionar uma série de proteínas interessantes para investigação como antígenos vacinais. Elas apresentam características de proteínas de superfície e, portanto, estariam expostas ao sistema imune do hospedeiro na infecção, proteínas secretadas, de adesão, ou associadas à atividade patogênica da bactéria. Proteínas da membrana externa são consideradas candidatas vacinais por serem geralmente abundantes e estarem em contato direto com o sistema imune do hospedeiro. Essas proteínas possuem domínios conservados encontrados em leptospiras patogênicas ampliando a proteção entre os diferentes sorovares (CULLEN et al., 2004). Existem estudos sobre antígenos com características de lipoproteínas de membrana externa (HAAKE, 2000), como LipL21 (CULLEN et al., 2003), LipL36 e LipL41, importantes na infecção renal (BARNETT et al., 1999), LipL32 (HAUK et al., 2005; HAAKE et al., 2000). Tambem tem sido estudadas as proteínas com atividade de adesão em fagócitos (CINCO et al., 2002) ou com capacidade hemolítica, como a HlyX (HAUK et al., 2005; BRANGER et al., 2005). Atualmente as proteínas LigA e LigB vem sendo bastante estudadas como possíveis antígenos vacinais. Essas proteínas possuem domínios repetidos de aproximadamente 90 aminoácidos similares a imunoglobulinas de bactérias. Segundo Choy et al. (2007) essas proteínas têm a capacidade de se ligar a proteínas da matriz extracelular e a fibrinogênio sugerindo que, devido à capacidade como adesinas, devem estar envolvidas na colonização inicial e disseminação das leptospiras. Alguns estudos mostraram que a imunização com a proteína LigA protege hamsters da morte na infecção por Leptospira interrogans sorovar Pomona e sorovar Copenhageni (PALANIAPPAN et al., 2006; SILVA et al., 2007), embora não seja uma proteção esterilizante, ou seja, os ris dos animais permanecem colonizados.

No Instituto Butantan, após a disponibilização dos dados do genoma da leptospira, iniciou-se o projeto de genoma funcional para estudo de vários antígenos com potencial vacinal, avaliando-se a imunogenicidade, conservação dos antígenos nas diferentes linhagens de leptospira e reconhecimento desses antígenos por anticorpos presentes no soro de pacientes de leptospirose (GAMBERINI et al., 2005), projeto no qual nosso trabalho se insere. 


\subsection{Salmonelas vacinais recombinantes}

Bactérias vivas atenuadas têm sido estudadas como vetores vacinais carregando antígenos ou DNA. Atualmente existem três linhagens de bactérias atenuadas licenciadas para uso humano, Mycobacterium bovis (BCG) (LAGRANDERIE et al., 2000), contra algumas formas de tuberculose, Vibrio cholerae CVD103-HgR, contra cólera (LEVINE e KAPER, 1993; SANCHEZ et al., 1994), e Salmonella Typhi Ty21a, contra febre tifóide (SPRENG et al., 2006). A linhagem Ty21a de Salmonella enterica sorovar Typhi é licenciada como vacina viva oral contra febre tifóide em humanos (LEVINE et al., 1989), e tem sido usada por 25 anos, mostrando-se estável e eficaz (KOPECKO et al.,2009). A vacina é administrada por via oral, em três ou quatro doses em um período de uma semana, com doses de 2 a $10 \times 10^{9}$ bactérias.

As bactérias atenuadas usadas como vetores vacinais apresentam a vantagem da imunização direta, sem necessidade de purificação e renaturação da proteína, processos caros e trabalhosos. Além disso, a bactéria pode agir como adjuvante e aumentar a resposta imune do organismo. A salmonela também promove a modulação da resposta imune, dirigindo para o tipo celular, o que muitas vezes é desejável.

Salmonelas com patogenicidade atenuada têm sido utilizadas como vacina devido a sua capacidade de invadir e permanecer nos hospedeiros por tempo suficiente para estimular o sistema imune (ROZENKRANZ et al., 2003). Salmonelas atenuadas são capazes de induzir a produção de várias citocinas (TNF- $\alpha$, IFN- $\gamma$ e IL-12) e mediadores pró-inflamatórios como óxido nítrico (SPRENG et al., 2006). Linhagens recombinantes de salmonelas têm sido utilizadas como formas de vacinas múltiplas, carregando antígenos heterólogos para apresentação ao sistema imune.

Um dos aspectos deste projeto é a utilização de salmonelas atenuadas carregando os genes de leptospira para a expressão in vivo, ou seja, no hospedeiro mamífero. Para estudos em camundongos a linhagem mais usada é Salmonella enterica sorovar Typhimurium. A atenuação da bactéria envolve mutações em genes das vias metabólicas, como a de biossíntese de aminoácidos aromáticos (genes aroA, aroC e aroD), de biossíntese de purinas (gene purA), genes que codificam adenilato ciclase ou seu receptor (genes cya e crp) (GARMORY et al., 2002). As mutações podem ser feitas também em genes envolvidos no sistema regulatório, responsáveis pela sobrevivência e virulência da bactéria, como os genes phoP/phoQ (MILLER, 1991). Existem estudos de atenuação da toxicidade de bactérias E. coli e Salmonella por mutação no gene $m s b B(w a a N)$. Esse gene codifica a miristil transferase, 
enzima responsável pela acilação secundária do lipídeo A do LPS das bactérias, o que é essencial para a atividade endotoxica da molécula de LPS (SOMERVILLE et al., 1996; KHAN et al., 1998; LOW et al., 1999). O LPS é um dos componentes da membrana externa de bactérias gram-negativas responsável pela ativação do sistema imune inato após o reconhecimento pelo receptor TLR4 em humanos. O componente lipídeo A do LPS foi descrito como a porção mais importante na atividade endotóxica devido a indução de mediadores como prostaglandinas e citocinas relacionadas com processo inflamatório. Recentemente um adjuvante para vacinas foi licenciado na Europa para uso em humanos baseado no lipídeo A de salmonela detoxificado, o monofosforil lipídeo A (MPLA). Esse adjuvante, adsorvido em Alhydrogel ou fosfato de alumínio, foi capaz de induzir resposta imune protetora sem induzir resposta tóxica (GARÇON et al., 2007; TAGLIABUE e RAPPUOLI, 2008).

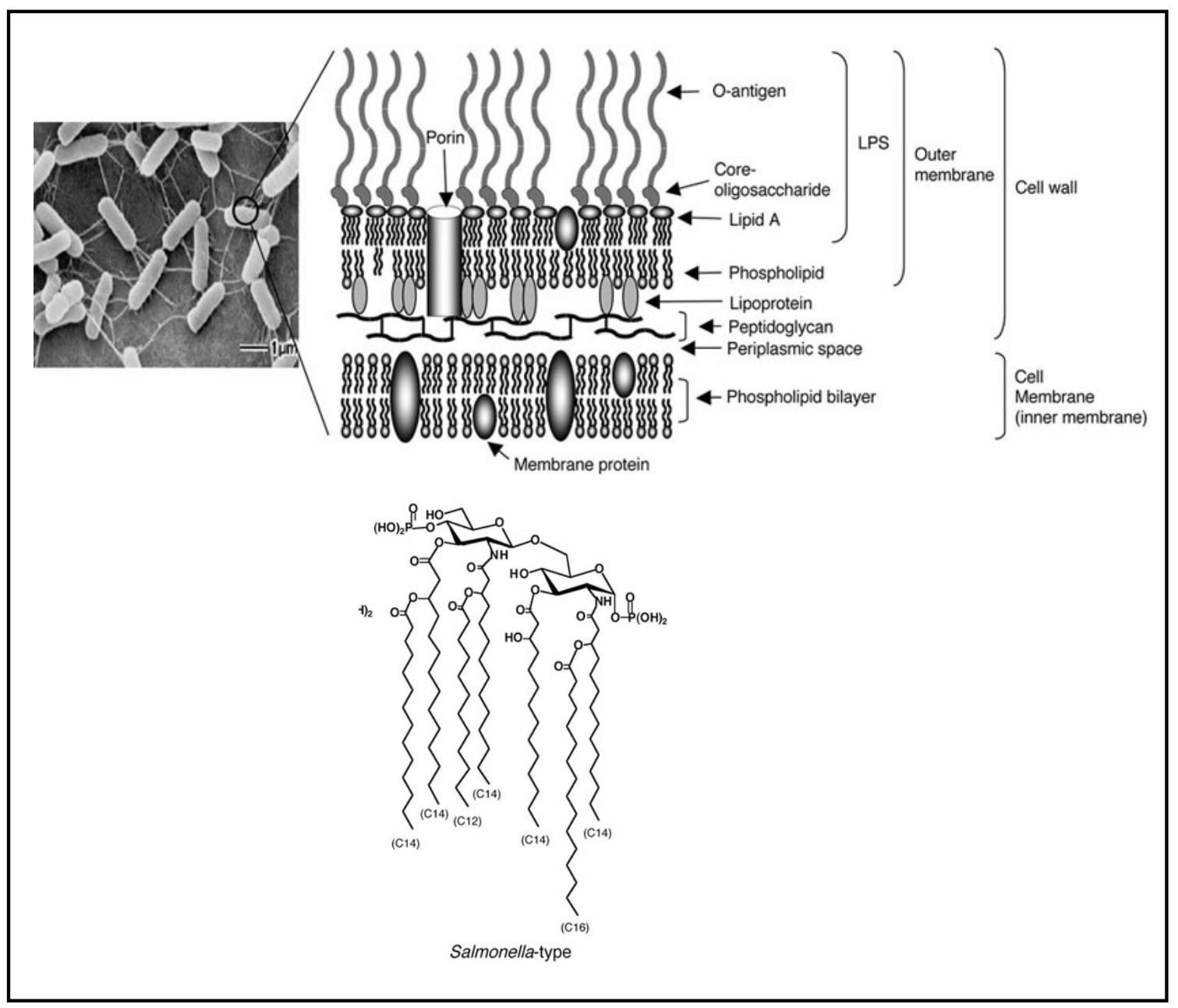

Figura 4 - Desenho esquemático da estrutura da membrana celular e parede da salmonela. Detalhe da composição do lipídeoA. 
Outros estudos utilizando frações de salmonelas como adjuvantes tem sido descrito na literatura, como a flagelina (SBROGIO-ALMEIDA et al., 2004, BARGIERI et al., 2010), também aproveitando o reconhecimento do sistema imune por moléculas de microrganismos.

A eficácia do uso das salmonelas inteiras atenuadas foi comprovada em estudos com genes de Schistossoma mansoni (PACHECO et al., 2005), com o antígeno PspA do pneumococo (KANG et al., 2002; XIN et al., 2009), antígenos F1 e V de Yersinia pestis (TITBALL et al., 1997; GARMORY et al., 2003), antígeno O de Pseudomonas aeruginosa (DiGIANDOMENICO et al., 2004).

Em nosso laboratório foram desenvolvidos ensaios com salmonelas vacinais recombinantes carregando o vetor pGEM-T Easy com o gene do fragmento $\mathrm{C}$ da toxina tetânica sob controle do sistema soxRpsoxS para expressão in vivo (TOMITA, 2005). Os resultados foram interessantes, determinando proteção dos animais imunizados em desafios com toxina tetânica. Isso incentivou o uso dessas bactérias e do sistema controlador de expressão gênica soxRpsoxS para estudos com genes de lepospira neste projeto.

Existem muitas considerações na literatura sobre o uso de salmonelas para vacinações múltiplas, uma vez que o reconhecimento especializado do sistema imune por LPS e desenvolvimento de anticorpos impediria a sobrevivência da bactéria em uma segunda ou terceira dose vacinal. Há controvérsias (DOMENECH et al., 2007; VINDURAMPULLE e ATTRIDGE, 2003) e também propostas de utilização de imunização "prime-booster" heteróloga (DOMENECH et al., 2008), ou seja, usando diferentes sorotipos em cada dose.

Para construções de clones recombinantes de salmonelas utilizamos a linhagem SL3261 (BROWN et al., 1987), uma linhagem de Salmonella enterica sorovar Typhimurium. mutada no gene aroA (AroA, 5-enolpyruvylshikimate 5-phosphate Synthase), descrita por Hoiseth e Stocker (1981). Essas bactérias necessitam de ácido p-aminobenzoico ( $p \mathrm{ABa}$ ) para sintetizar, por exemplo, 2,3 - dihidroxibenzoato (DHB) e ácido fólico, precursores de compostos para aquisição de ferro da bactéria. A salmonela sintetiza $p \mathrm{ABa}$ e $\mathrm{DHB}$ de corismato, produto final da via de biossíntese de aromáticos (aro). O bloqueio em algum passo desta via torna a salmonela auxotrófica para dois componentes, os quais não disponíveis em tecidos de vertebrados, e portanto, atenua a virulência. No trabalho de Hoiseth e Stocker foi descrita a deleção do gene aroA originando a cepa vacinal de Salmonella typhimurium SL3261. A maior dose administrada em camundongos BALB/c foi $3 \times 10^{6}$ bactérias via intraperitoneal. Em nenhum grupo foi observado sinais de doença nos animais. Todos os animais sobreviveram após o desafio com a cepa selvagem virulenta, tanto por via 
intraperitoneal, quanto pela via oral (HOISETH e STOCKER, 1981), comprovando a capacidade vacinal da cepa SL3261 viva.

\section{$1.6 O$ regulon soxRS e o vetor pAEsox}

As bactérias entéricas possuem sistemas de defesa que respondem ao estresse oxidativo imposto pelos macrófagos durante infecção (DEMPLE et al., 1999). Um desses sistemas é o regulon soxRS, o qual é ativado por anions superóxido e oxido nítrico e promove a expressão de várias proteínas relacionadas com atividade antioxidante. Estudos indicam que a indução deste sistema ocorre em duas fases distintas, inicialmente um sinal redox ativa a proteína SoxR preexistente que, ligada ao promotor do gene soxS, induz forte transcrição. A proteína SoxS por sua vez, vai induzir a expressão dos vários genes do regulon, como superóxido dismutase A, endonuclase IV, fumarato desidrgenase etc. (AMÁBILE-CUEVAS e DEMPLE, 1991; NUNOSHIBA et al., 1992).

O vetor pAE foi construído no Centro de Biotecnologia (Instituto Butantan) a partir de vetores comerciais pRSET e pET (RAMOS et al., 2004), para expressão de proteínas em $E$. coli, por indução com IPTG. O vetor pAE foi modificado novamente no laboratório por inserção de parte do lócus do sistema controlador do regulon soxRS, o gene de soxR e o promotor de soxS, de modo a controlar a expressão de genes de interesse por estresse oxidativo. $\mathrm{O}$ vetor permite indução in vitro por exposição das bactérias transformadas a paraquat, uma bipiridina que promove estresse oxidativo. A indução de expressão ocorre in vivo quando as bactérias transformadas são fagocitadas pelos macrófagos e são expostas ao "burst" oxidativo. Esse sistema foi testado no laboratório e mostrou-se funcional em camundongos. 


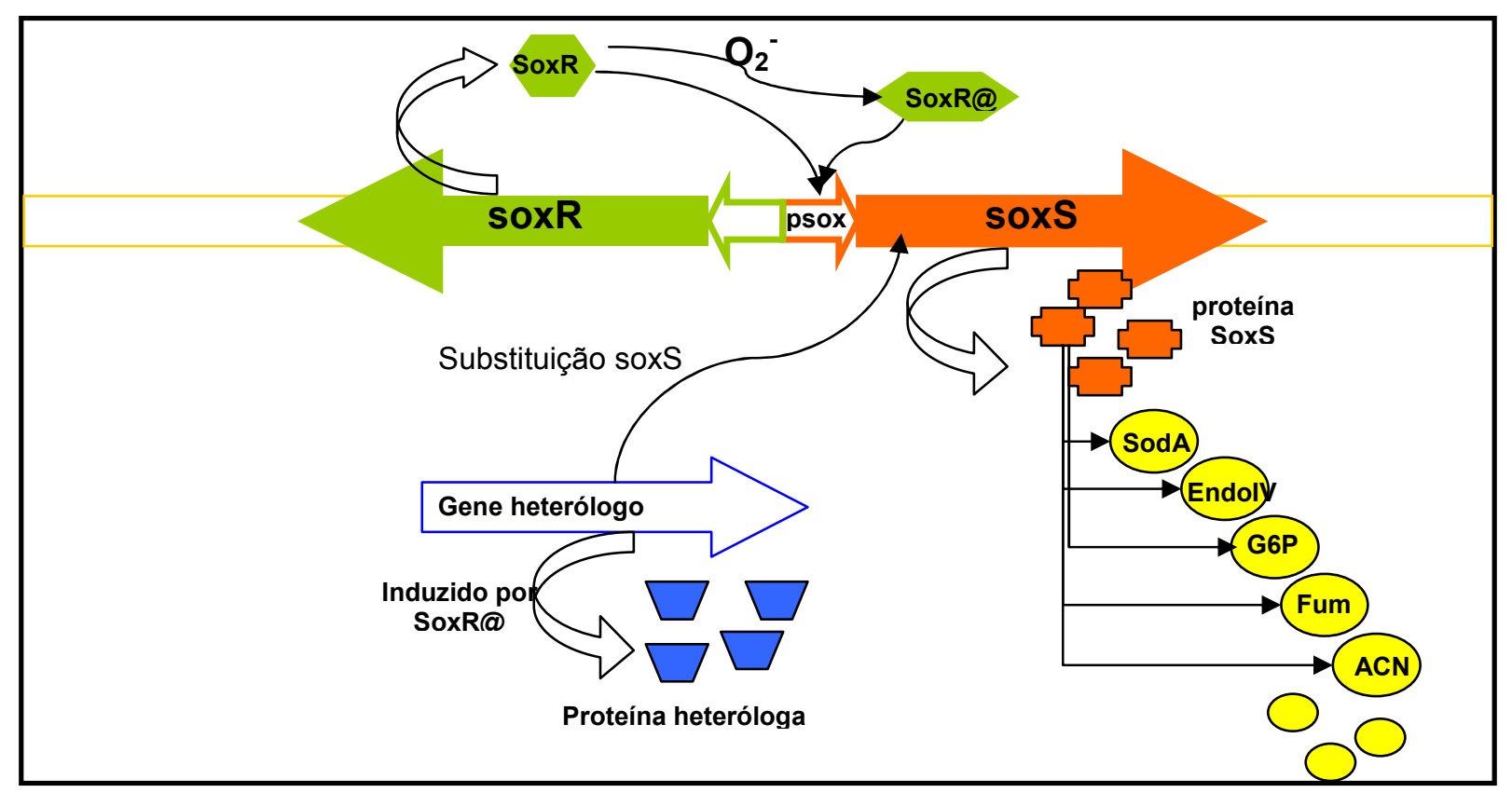

Figura 5 - Esquema do sistema controlador do regulon soxRS e sua utilização para controle de expressão de genes heterólogos. Ativação e mudança de conformação da proteína SoxR causada por superóxido, indução de expressão da proteína SoxS e indução de outras proteínas do regulon pela SoxS. Esquema da substituição do gene soxS por genes heterólogos, para expressão sob extresse oxidativo 


\section{OBJETIVOS}

Os objetivos desse projeto são: investigar o potencial vacinal de antígenos de leptospira e o potencial de uso dessas proteínas em testes de diagnóstico. Investigar a resposta imune quando esses antígenos são apresentados por salmonelas vacinais recombinantes.

Etapas de desenvolvimento do projeto:

1- Amplificação dos genes por PCR e clonagem inicial para produção de massa de plasmideos com os fragmentos de interesse.

3- Transferência dos genes para os vetores de expressão pAE e pAEsox.

4- Análise da expressão das proteínas recombinantes em E. coli por indução in vitro com IPTG ou paraquat.

5- Transferência das construções para obtenção de clones recombinantes em salmonela e análise da expressão dos antígenos in vitro.

6- Testes de antigenicidade com soros de animais infectados e pacientes de leptospirose por western blot.

7- Imunização de camundongos e hamsters para obtenção de soros.

8- Imunização de hamsters para ensaios de desafio.

9- Testes de imunogenicidade por ELISAs e Western blots. 


\section{MATERIAIS E MÉTODOS}

\subsection{Linhagens de bactérias utilizadas}

- $\quad$ E. coli DH5a - para a amplificação de plasmídeos;

- $\quad$ E. coli BL21(DE3)StarpLysS - para a expressão de proteínas recombinantes; possui o gene T7 RNA polimerase integrado no cromossomo induzível por IPTG. Os genes recombinantes são clonados sob controle do promotor T7, reconhecido pela RNA polimerase.

- Salmonella enterica sorovar Typhimurium SL3261 - genótipo (Lt2 aro $A^{-}$); linhagem vacinal para camundongos, atenuada por mutação no gene aroA. Utilizada para expressão das proteínas in vivo.

- Salmonella enterica sorovar Typhimurium SL4213 - usada para a transferência dos plasmídeos de E. coli para a salmonela vacinal. Possui genótipo deficiente no sistema de restrição de reconhecimento de DNA exógeno.

\subsection{Preparo de bactéria competente e transformação}

As bactérias $E$. coli e salmonelas foram preparadas quimicamente para transformação por choque térmico com as construções plasmidiais. (SAMBROOK et al., 1989)

\subsubsection{Meios de cultura para crescimento de bactérias}

- 2 YT (pH 7,0) - Triptona 1,6\%, extrato de levedo 1\%, cloreto de sódio $0,5 \%$ em água LB ( $\mathrm{pH} 7,0)$ - Triptona $1 \%$, extrato de levedo $0,5 \%$, cloreto de sódio $1 \%$ em água

- LB-ágar e 2YT-ágar - 1,5\% de select-ágar em meio de cultura liquido.

- SOB - Triptona $1,6 \%$, extrato de levedo $0,4 \%$, Cloreto de sódio $0,5 \%$, cloreto de potássio $0,02 \%$ em água

- $\mathrm{SOC}$ - adicionar glicose $0,36 \%$ estéril em meio SOB

- Antibióticos - Ampicilina $100 \mu \mathrm{g} / \mathrm{ml}$

Novobiocina $20 \mu \mathrm{g} / \mathrm{ml}$ 


\subsubsection{Materiais e soluções para preparo de bactéria competente}

- Solução de $\mathrm{MgCl}_{2} 1 \mathrm{M}$

- Solução RFI - KCl $1 \mathrm{M}, \mathrm{MnCl}_{4} \cdot 2 \mathrm{H}_{2} \mathrm{O} 1 \mathrm{M}$, acetato de potássio 0,5 M, $\mathrm{CaCl}_{2} \cdot 2 \mathrm{H}_{2} \mathrm{O} 1$ M, glicerol 15\% em água milliQ

- Solução RFII - KCl 0,5 M, $\mathrm{CaCl}_{2}$. $2 \mathrm{H}_{2} \mathrm{O} 1 \mathrm{M}$, Na-MOPS 0,5 M pH 7,0, glicerol 15\% em água milliQ.

- Solução de PIPES - cloreto de cálcio 60 mM; glicerol 15\%; PIPES 10 mM; em água deionizada); pH 7,0; esterilizada por filtração em membrana de $0,22 \mu \mathrm{m}$;

- Espectrofotômetro - Ultrospec 2000 - Pharmacia Biotech para o acompanhamento das D.O.600nm

- Centrífuga para tubos de $50 \mathrm{ml}$ - Juan CR3i

- Estufa com agitação - HT INFORS minitron

- Capela fluxo laminar

- micropipetas

\subsubsection{Preparação de E. coli competente}

As linhagens de bactérias E. coli utilizadas foram preparadas pelo tratamento com soluções contendo cloreto de cálcio seguindo a metodologia descrita por SAMBROOK et al.. (1989). As bactérias, armazenadas em freezer $-80{ }^{\circ} \mathrm{C}$, foram estriadas em placas contendo meio 2YT-ágar e incubadas a $37^{\circ} \mathrm{C}$ por 16 horas. Uma colônia isolada da placa foi inoculada em $2 \mathrm{ml}$ de meio de cultura LB e incubada a $37{ }^{\circ} \mathrm{C}$ por 16 horas sob agitação. A cultura foi diluída em $100 \mathrm{ml}$ de meio $\mathrm{LB}$ e incubada a $37{ }^{\circ} \mathrm{C}$ sob agitação até a $\mathrm{DO}_{600 \mathrm{~nm}} 0,6$. Foi adicionada à cultura, $4 \mathrm{ml}$ de solução de cloreto de magnésio $1 \mathrm{M}$, e deixada no gelo por 15 minutos. A cultura foi então centrifugada a 3214 g por 10 minutos a $4{ }^{\circ} \mathrm{C}$ e o sobrenadante foi retirado. O sedimento celular foi ressuspendido em $5 \mathrm{ml}$ de solução RFI gelada e a suspensão centrifugada a 2057 g por 15 minutos a $4{ }^{\circ} \mathrm{C}$. O sobrenadante foi descartado. A lavagem com a solução RFI foi repetida mais uma vez. O sedimento restante foi ressuspendido em $1 \mathrm{ml}$ de solução RFII e dividido em alíquotas de $50 \mu \mathrm{l}$ em tubos de $1,5 \mathrm{ml}$ gelados e foram aramzenadas a $-80^{\circ} \mathrm{C}$. 


\subsubsection{Preparação de salmonela competente}

As bactérias salmonelas foram preparadas de forma ligeiramente diferente das bactérias E. col, sendo utilizada solução tampão PIPES. As bactérias armazenadas a $-80{ }^{\circ} \mathrm{C}$ foram estriadas em placas contendo meio $2 \mathrm{YT}$-ágar e incubadas a $37^{\circ} \mathrm{C}$ por 16 horas. Uma colônia isolada foi inoculada em $5 \mathrm{ml}$ de meio $2 \mathrm{YT}$ e incubada a $37^{\circ} \mathrm{C}$ por 16 horas sob agitação. A cultura foi diluída em $500 \mathrm{ml}$ de meio $2 \mathrm{YT}$ e incubada a $37^{\circ} \mathrm{C}$ sob agitação até a $\mathrm{DO}_{600 \mathrm{~nm}} 0,4$. A cultura foi então centrifugada a $1500 \mathrm{~g}$ por 15 minutos a $4{ }^{\circ} \mathrm{C}$ para a retirada do meio de cultura. O precipitado bacteriano foi ressuspendido em $20 \mathrm{ml}$ de solução de PIPES estéril gelada e a suspensão centrifugada novamente a 1500 g por 14 minutos a $4{ }^{\circ} \mathrm{C}$. O procedimento foi repetido duas vezes antes de ressuspender as células em $250 \mu 1$ de solução de PIPES. A suspensão foi dividida em alíquotas de $50 \mu$ que foram armazenadas a $-80{ }^{\circ} \mathrm{C}$.

\subsubsection{Transformação de bactéria competente por choque térmico}

As bactérias competentes foram usadas para introdução de plasmídios com as contrucões recombinantes dos genes a serem estudados. Em sua maioria os plasmideos conferiam resistência à ampicilina, usado como pressão seletiva no meio. A transformação de bactérias foi utilizada com o objetivo de amplificar os vetores e também para gerar os clones para expressão de protenas recombinantes.

\subsubsection{Materiais e soluções para transformação de bactéria competente}

- Tropi Cooler mode 260014 - Boekel Scientific

- Estufa - HT INFORS minitron

- Meio de cultura liquido 2YT

- Placas 2YT-ágar com antibiótico

- Alça plástica estéril descartável para plaqueamento

\subsubsection{Procedimento para transformação de bactéria competente}

Para reação de transformação, alíquotas de $50 \mu$ de células quimicamente competentes foram descongeladas em gelo e receberam $1 \mu 1$ a $2 \mu 1$ de mini-preparações dos plasmídeos de 
interesse ou $5 \mu 1$ das reações de ligação vetor/inserto. As misturas foram mantidas em gelo por mais 30 minutos. As células foram então submetidas a $42{ }^{\circ} \mathrm{C}$ por 2 minutos e novamente submetidas ao banho de gelo por 5 minutos. Após o choque térmico, adicionamos $450 \mu \mathrm{l}$ de meio de cultura $2 \mathrm{YT}$ às suspensões de células e incubamos a $37{ }^{\circ} \mathrm{C}$ por 90 minutos. Após este período, plaqueamos volumes variados destas suspensões em meio 2YT-ágar contendo os antibióticos apropriados, para obtenção de colônias isoladas. As colônias foram selecionadas para estabelecimento dos clones por cultivo em meio de cultura liquido e armazenamento com $15 \%$ de glicerol.

\subsection{Amplificação dos genes por PCR e inserção nos vetores de expressão}

\subsubsection{Escolha dos genes e desenho de primers (programas utilizados)}

As anotações dos genomas da Leptospira interrogans sorovar lai e Leptospira interrogans sorovar Copenhageni foram estudas para busca de genes com potencial vacinal. A escolha foi feita previamente ao inicio deste trabalho, baseando-se em análise funcional das proteínas, buscando, por exemplo, domínios indicativos de proteínas exportadas, ou presentes na membrana ou relacionadas com a virulência. $\mathrm{Na}$ análise foram utilizados os programas:

- Orf finder: para análise de sequências codificadoras de proteinas

- Blast: comparação de sequências de nucleotídeos e proteínas com um banco de dados. Ajuda a identificar famílias de sequências e traçar relação funcional;

- Psort: predição da localização das proteínas nas células;

- Expasy: utilizado para análise de sequências e estruturas de proteínas.

Os genes selecionados foram estudados para desenho de "primers", para amplificação e clonagem. Para desenho dos primers foi usado o programa generunner, de maneira a amplificar os genes escolhidos com adição de sítios de clivagem por enzimas de restrição, e posicionamento no quadro correto de leitura no vetor de expressão. A Tabela 1 mostra os pares de oligonucleotideos iniciadores "Forward' e reverso desenhados para amplificação de cada gene. 
Tabela 1 - Oligonucleotídeos iniciadores utilizados para a amplificação gênica por PCR, tamanho dos fragmentos gênicos e massa molecular esperada para as proteínas.

\begin{tabular}{|c|c|c|c|}
\hline Gene & Iniciadores* & $\begin{array}{c}\text { Fragmento } \\
\text { pb }\end{array}$ & $\begin{array}{c}\text { Massa } \\
\text { proteína } \\
\text { kDa }\end{array}$ \\
\hline LIC10191 (Loa22) & $\begin{array}{l}\text { ggatccACTCTCTGCTCCTCTGCTGA BamHI } \\
\text { ctgcagAATTATTGTTGTGGTGCGGAA PstI }\end{array}$ & 536 & 20,9 \\
\hline LIC10793 (Lp49) & $\begin{array}{l}\text { ggatccGACTTTTCTTTACTTTCTTCTCC BamHI } \\
\text { aagcttGTCGTAGACTTAAAAACCATCTC HindIII }\end{array}$ & 1275 & 51,8 \\
\hline LIC12302 & $\begin{array}{l}\text { ggatccATGATCGGAATGGGAATCG BamHI } \\
\text { GTATAAGCTTGCAATTCGTTTC HindIII }\end{array}$ & 1138 & 37,5 \\
\hline LIC12659 (VapB) & $\begin{array}{l}\text { ggatccATGCAAACAGCCAAATTATTTA BamHI } \\
\text { aagcttTAAGATTTTCTAACAGAGTCGC HindIII }\end{array}$ & 303 & 8,7 \\
\hline LIC10537 (OmpA76) & $\begin{array}{l}\text { ggatccCATACCCTGCTGACTCTGATC BamHI } \\
\text { aagcttATCCTTGCACCGAACACACG HindIII }\end{array}$ & 2026 & 76,0 \\
\hline LIC1 1227 (OmpL17) & $\begin{array}{l}\text { ggatccTCGATCACACTCCTGAGCCA BamHI } \\
\text { aagcttAAATGGAGCAACCGAACGTC HindIII }\end{array}$ & 692 & 27,1 \\
\hline LIC10508 (LipL23) & $\begin{array}{l}\text { ggatccGGTTGTAAAAAGAGCAAAGAAG BamHI } \\
\text { aagcttCGTTACTAACAACCAGGACC HindIII }\end{array}$ & 563 & 22,2 \\
\hline LIC10868 & $\begin{array}{l}\text { ggatccTTGAATTTAGGTTTCGCCGTT BamHI } \\
\text { aagcttACAACAAAAATAATCGCCCG HindIII }\end{array}$ & 1713 & 48,8 \\
\hline LIC12033 (AnkB) & $\begin{array}{l}\text { ggatccATGGATCAATCAACTGAAATTC BamHI } \\
\text { aagcttACCTCCAGCTGTAGTAAGGG HindIII }\end{array}$ & 578 & 21,9 \\
\hline LIC13101 & $\begin{array}{l}\text { ggatccGGAAGTAAAAATTCCCTACC BamHI } \\
\text { aagcttGGAAGAAAATCTACCGATGTG HindIII }\end{array}$ & 3751 & 127,1 \\
\hline
\end{tabular}

*Os nucleotídeos em letra minúscula/sublinhados representam os sítios de restrição utilizados

\subsubsection{Materiais e soluções para reação de polimerização em cadeia (PCR)}

- Reagentes: água milliQ, tampão com $\left(\mathrm{NH}_{4}\right)_{2} \mathrm{SO}_{4}, \mathrm{MgCl}_{2}$ (3 mM final), dNTP mix (10 $\mathrm{mM}$ ), iniciador "forward" 10 pmol, iniciador "reverse" 10 pmol e enzima DNA taq polimerase (Fermentas).

- Termociclador: PTC- $100^{\mathrm{TM}}$ (Programmable Thermal Controller) - MJ Research, Inc. Programa padronizado para cada reação de PCR

PCR foi utilizado para amplificação dos genes de interesse utilizando DNA genômico como molde. 


\subsubsection{Vetores utilizados}

- pGEMT-Easy (Promega) foi utilizado para ligação dos produtos de PCR. Este vetor é comercializado linearizado e possui uma base $\mathrm{T}$ livre em cada extremidade, permitindo a inserção dos produtos de PCR que tiverem a base A adicinada nas extremidades. O pGEMT possui origem de replicação pUC ori que permite a propagação em bactérias, um gene que confere resistência a ampicilina e o gene lacZ que, disrompido pela presença do inserto, permite a seleção de clones positivos por formação de colônias brancas em presença de X-gal.

- pAE - vetor de expressão derivados do vetor pRSET (Invitrogen), modificado por Ramos e colaboradores no Centro de Biotecnologia do Instituto Butantan (RAMOS et al., 2004). O vetor pAE possui pUC ori, gene bla para $a m p^{\mathrm{R}}$, sítio RBS (reconhecimento no ribossomo), código de iniciação seguido de código para 6 histidinas em quadro correto e leitura com o gene de interesse e sítio de múltiplas clonagens. Este sistema possibilita a purificação da proteína recombinante expressa em colunas de afinidade a metal (IMAC) através dos seis resíduos de histidinas adicionados na extremidade amino-terminal da proteína expressa.

- O vetor pAEsox foi gerado no laboratório por modificação do vetor pAE (Figura 6), por inserção de parte do sistema controlador do regulon "soxRS" (DEMPLE et al., 1996). A utilização do vetor pAEsox tem por objetivo induzir a expressão das proteínas recombinantes in vitro e in vivo por estresse oxidativo. O regulon "soxRS" é ativado por ânions superóxidos e radicais de óxido nítrico e promove a expressão de proteínas relacionadas com atividade antioxidante. Quando a proteína SoxR é ativada, ela se liga ao promotor do gene soxS induzindo a transcrição. Na clonagem em vetor pAEsox o gene soxS é substituído pelo gene da proteína de interesse. A expressão da proteína pode ser testada in vitro por adição de paraquat à cultura de bactérias. 


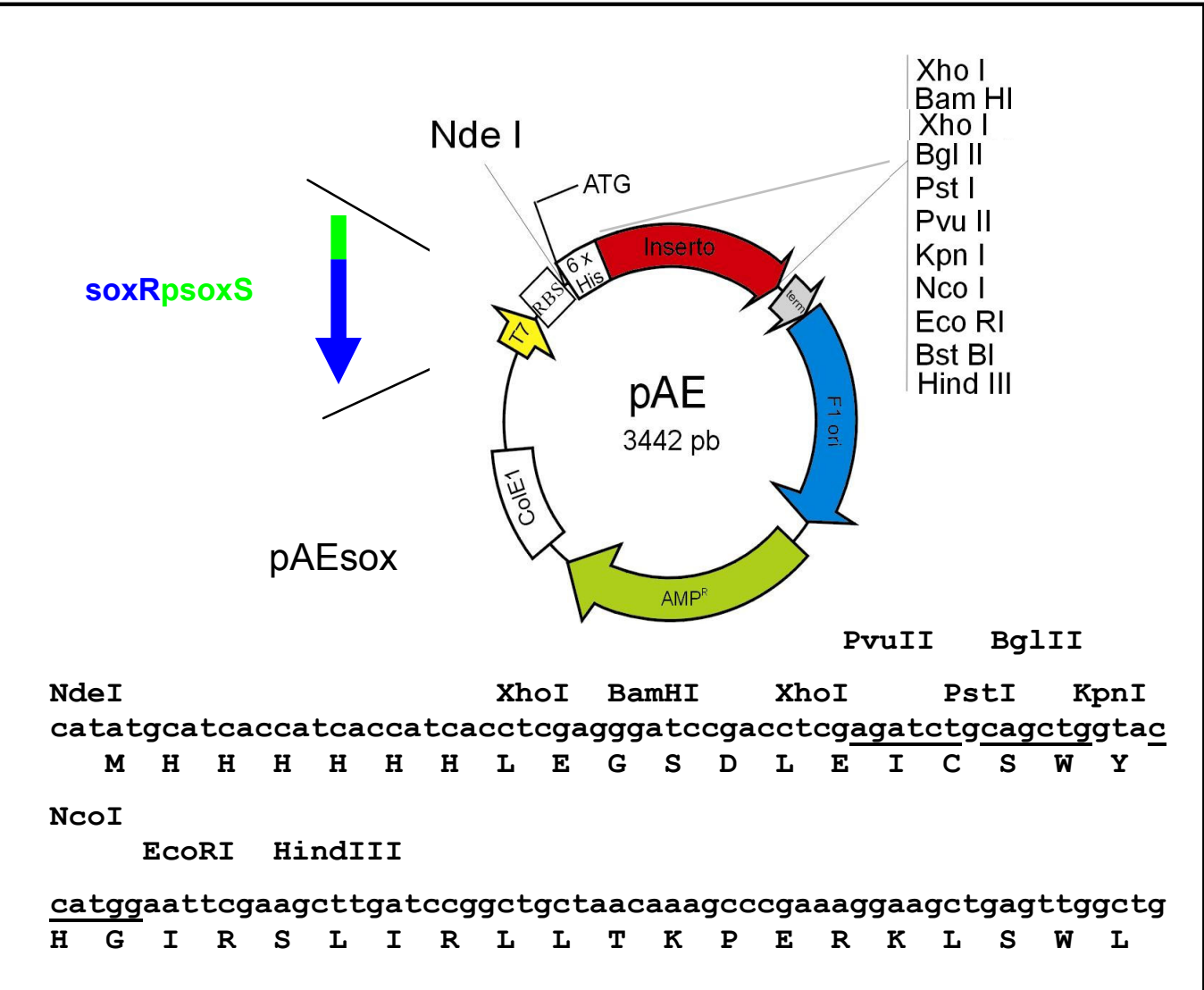

Figura 6 - Vetor de expressão pAE e esquema da inserção de parte do locus soxRS. Destaque para o sítio de mútiplas clonagens do vetor.

Os genes de leptospira (Tabela 1) foram amplificados por PCR a partir do DNA genômico da Leptospira interrogans sorovar Copenhageni (Copenhageni Fiocruz L1-130) disponível no laboratório. Foram usados oligonucleotídeos iniciadores especialmente desenhados com sítios de restrição nas pontas para a inserção do fragmento no vetor de expressão pAEsox. Para as amplificações preparamos reações de $50 \mu 1$ contendo $1 \mu 1$ do DNA molde, 10 pmol de cada oligonucleotídeo ("forward" e "reverse"), $5 \mu$ de tampão 10X para PCR, $1 \mu l$ de enzima taq polimerase (Fermentas) e água MilliQ. As amostras foram colocadas em termociclador (PTC-100, MJ Research, Inc). O ciclo utilizado foi: $95^{\circ} \mathrm{C}$ por 5 minutos, para a denaturação da dupla fita de DNA e 40 ciclos de $95{ }^{\circ} \mathrm{C}$ por 30 segundos, $52{ }^{\circ} \mathrm{C}$ a $58^{\circ} \mathrm{C}$ por 15 segundos, para o anelamento dos primers e $70^{\circ} \mathrm{C}$ por 1 a 3 minutos, para a extensão das fitas. Ao final dos ciclos, deixamos as amostras a $70^{\circ} \mathrm{C}$ por 5 minutos para a extensão final. As temperaturas utilizadas no anelamento dos primers foram padronizadas para cada gene amplificado.

Amostras ou todo o volume das reações de amplificação foram separados por eletroforese em gel de agarose para avaliação dos fragmentos e para purificação. Nas 
purificações foi utilizado kit comercial Concert $^{\mathrm{TM}}$ Gel Extraction Systems - Life Technologies $^{\mathrm{TM}}$, apropriado para extração e DNA de gel. Os produtos de amplificação purificados foram utilizados para a ligação em vetor pGEM-T Easy.

As reações de ligação foram realizadas com $1 \mu \mathrm{l}$ do vetor pGEM-T Easy, $1 \mu \mathrm{l}$ de enzima T4 DNA ligase, $5 \mu 1$ de tampão de ligação e $3 \mu 1$ do produto de PCR purificado. Após a incubação das reações por 1 hora a TA, uma alíquota de $5 \mu 1$ foi utilizada para transformar bactérias E. coli DH5a. A transformação foi feita por choque térmico e as suspensões de bacterias foram plaqueadas em 2YT-amp-XGal para seleção de clones com o plasmideo com inserto.

Os clones de E. coli contendo os plasmídeos de interesse foram cultivados em $5 \mathrm{ml} \mathrm{de}$ meio de cultura 2YT liquido contendo ampicilina. As culturas cresceram durante 16 horas a $37{ }^{\circ} \mathrm{C}$, as bactérias foram separadas por centrifugação e lisadas para a extração de DNA plasmideal utilizando kit comercial para "mini-prep" (Concert Gibco, GE Healthcare ou Qiagen). A purificação do plasmideo incluia uma separação em resina e a eluição final do DNA foi feita em $100 \mu 1$ de solução de tampão tris-EDTA. Cada amostra foi verificada em gel de agarose $0,8 \%$ em tampão TAE $1 \mathrm{X}$, corado com $0,5 \mu \mathrm{g} / \mu \mathrm{l}$ de brometo de etídio para a visualização do DNA sob luz UV. As amostras também foram seqüenciadas utilizando os oligonucleotídeos M13F e M13R para confirmação das construções.

\subsubsection{Clonagem dos genes nos vetores de expressão}

Após a verificação das clonagens em vetor pGEMT-Easy, amostras foram digeridas com enzimas de restrição previstas nos primers para recuperação do fragmento de interesse e clonagem nos vetores de expressão pAE e pAEsox, respeitando o quadro correto de leitura para expressão das proteínas com os 6 resíduos de histidinas na posição N-terminal.

Para obtenção dos fragmentos gênicos de interesse, amostras de minipreparações dos vetores de clonagem inicial foram submetidas à digestão com uma ou outra das enzimas de restrição previstas, para utilização do tampão adequado e garantia da atividade de cada enzima. Para tanto, amostras de $25 \mu 1$ das minipreparações foram digeridas com uma ou outra enzima prevista e a digestão avaliada em gel de agarose. Em seguida as amostras recebiam a outra enzima para separação dos fragmentos. No caso de tampões incompatíveis era feita purifição do fragmento após a primeira clivagem, usando kit de purificação GFX PCR DNA and Gel Band Purification Kit (GE Helthcare). As reações de digestão eram mantidas por $2 \mathrm{~h}$ a $37^{\circ} \mathrm{C}$. 
Os genes amplificados por PCR e clonados no vetor pGEM-T-Easy foram digeridos com as enzimas previstas (Tabela 1) Os genes LIC10325, LIC11352 e LIC10465 já haviam sido clonados no vetor pAE ou pDEST e foram utilizados para a subclonagem nos vetores de expressão. Os fragmentos gênicos LIC11352 e LIC10465 já clonados em vetor pAE foram clivados com as enzimas NdeI e HindIII e XhoI e PstI, respectivamente. Para o gene LIC10325, clonado em vetor pDEST, foram utilizadas as enzimas NdeI e EcoRI.

Após o processo de digestão, as amostras foram verificadas em gel de agarose $0,8 \%$ para visualização das bandas correspondentes ao fragmento de interesse. Confirmada a digestão todo material foi aplicado em um novo gel de agarose $0,8 \%$ e a banda, com o tamanho correspondente ao fragmento foi purificada do gel usando o kit comercial (Qiagen ou GE Heathcare). Os vetores pAE e pAEsox foram digeridos com as mesmas enzimas e purificados para receber os fragmentos .

Os fragmentos de interesse e o vetor digerido com os mesmos sítios foram utilizados em reações de ligase utilizando enzima T4 DNA ligase (Fermentas). Após 60 minutos de incubação a TA. Amostras das reações de ligação foram utilizadas para transformar bactérias E. coli $\mathrm{DH} 5 \alpha$ pelo método de choque térmico.

\subsection{Eletroforese em gel de agarose para análise de fragmentos gênicos}

As amostras de DNA amplificadas por PCR e das minipreparações plasmidiais foram analizadas em gel de agarose utilizando marcador padrão de massa e tamanhos de DNA para comparação dos fragmentos.

\subsubsection{Materiais e soluções para eletroforese em gel de agarose}

- Agarose - $0,8 \%$ ou $1,0 \%$ em tampão TAE

- Tampão TAE (pH 8,5) - Tris-acetato 40 mM e EDTA 1 mM (pH 8,0) em água destilada.

- Tampão de amostra para DNA - Glicerol 50\%, azul de bromofenol 0,25\%, xileno cianol 0,5\% em água milliQ.

- Marcador de massa e tamanhos de fragmentos de DNA - 1kb DNA ladder - Fermentas

- Solução de brometo de etídeo $10 \mathrm{mg} / \mathrm{ml}$

- Cuba para eletroforese - Mini-sub cell GT cell - Biorad 
- Fonte para eletroforese - BioRad Power PAC 300

- Stratagene Eagle Eye II Video Imaging System

\subsubsection{Procedimento para eletroforese em gel de agarose}

As amostras de DNA foram analisadas em géis de agarose seguindo o protocolo descrito por Sambrook, 1989. Aos géis de agarose em tampão TAE com brometo de etídeo (4 $\mu \mathrm{l}$ de solução para $100 \mathrm{ml}$ de gel) foram aplicadas as amostras em tampão de amostra. As corridas foram feitas com voltagem $70 \mathrm{~V}$ por aproximadamente 45 minutos. Após a corrida o gel foi visualizado sob luz UV e fotografado para registro. As amostras foram comparadas com o padrão de massa/tamanho (GeneRuler 1kb DNA Ladder - Fermentas), também aplicado ao gel.

\subsection{Método fenol:clorofórmio para análise da presença de inserto em vetores clonados}

Para análise dos plasmideos diretamente clones bacteranos recuperados das placas de agar após a transformação, utilizamos o teste de fenol-clorofórmio descrito por Beuken et al. (1998).

\subsubsection{Materiais e soluções para teste de fenol-clorofórmio}

- Centrifuga para tubos de 1,5 ml/ $2 \mathrm{ml}$ - Eppendorf Centrifugue 5415R

- Solução de fenol:clorofórmio (1:1)

- Tampão de amostra para gel de agarose

- Agitador de tubos - Type 16700 Mixer Maxi-Mix I - Barnstead/Thermolyne

\subsubsection{Procedimento para teste de fenol-clorofórmio}

Para o teste rapido de presença de iserto nos clones plasmideais pelo método fenolclorofórmio, várias colônias isoladas das placas de agar foram inoculadas em $2 \mathrm{ml}$ de meio 2YT contendo ampicilina para crescimento a $37^{\circ} \mathrm{C}$ por aproximadamente 16 horas. $\mathrm{O}$ mesmo foi feito com uma colônia contendo o vetor vazio (sem inserto) para ser usado como controle negativo. Após a incubação, centrifugamos uma alíquota de $400 \mu \mathrm{l}$ de cada cultura foi a 
$16000 \mathrm{~g}$ por 3 minutos e descartamos o sobrenadante. O sedimento foi ressuspendido em 100 $\mu 1$ de tampão de amostra para gel de agarose $2 X$ e $38 \mu 1$ de solução de fenol-clorofórmio (1:1) e agitado vigorosamente. A amostra foi então centrifugada novamente a 16000 g por 3 minutos e $15 \mu 1$ de cada amostra foram aplicados em um gel de agarose 1,0\% com brometo de etídeo. Neste teste podemos observar no gel uma banda reativa ao DNA cromossômico da bactéria, uma banda relativa ao DNA plasmidial e ainda três banda de RNA. Os clones relativos aos plasmideos de interesse são selecionados por comparação em tamanho com a banda do DNA plasmidial do vetor vazio da cultura controle. Os clones selecionados foram crescidos para preparo de plamideos por mini preparações convencionais.

\subsection{Seqüenciamento de DNA}

Os plasmídeos recombinantes e os fragmentos gênicos amplificados por PCR foram confirmados por seqüenciamento de DNA utilizando o método de Didesoxi de Sanger adaptado para seqüenciador automático capilar ABI3100 (Perkin Elmer). A máquina para sequenciamento de DNA está disponível no Centro de Biotecnologia.

O protocolo de seqüenciamento utiliza 150 ng do DNA plasmidial (preparado usando o kit da Gibco) e 1,6 pmol de oligonucleotideos iniciadores. No sequenciamento utiliza-se o kit Bigdye terminator da Perkin Elmer, seguindo protocolos dos fabricantes. Utilizamos os oligonucleotídeos M13F e M13R para sequenciamento dos clones em pGEM-T Easy, para os clones em pAE e pAEsox utilizamos T7 e PRSetRev. Os clones em pAEsox também foram seqüenciados usando um oligonucleotídeo denominado SoxMeio. Na Tabela 2 estão descritos os oligonucleotídeos utilizados nos seqüenciamentos. Quando necessário, utilizamos os mesmos oligonucleotídeos usados nas amplificações gênicas. As amostras seqüenciadas foram analisadas comparando com as sequências originais para a verificação de mutações como troca de pares de bases, deleções ou inserções. 
Tabela 2 - Oligonucleotídeos utilizados nos sequenciamentos

\begin{tabular}{lc}
\hline & Oligo nucleotídeos \\
\hline M13 Fow & GTTTTCCCAGTCACGAC \\
M13 Rev & CAGGAAACAGCTATGAC \\
T7 & TAA TAC GAC TCA CTA TAG GG \\
pRSET & CTTTGAGTGAGCTGATACCG \\
pRSET rev & ATGCTAGTTATTGCTCAGCGGTGG \\
soxmeio & CCGCTACGTTTCGCAACTTC \\
\hline
\end{tabular}

\subsection{Expressão das proteínas recombinantes em $E$. coli}

Utilizamos clones de E. coli com as construções com genes de interesse nos dois vetores pAE e pAEsox, para verificar a expressão in vitro das proteínas recombinantes.

\subsubsection{Materiais e soluções para expressão de proteínas}

- Meio de cultura liquido 2YT com antibiótico

- Solução de glicerol 50\% esteril

- Indutores: IPTG e paraquat

- Espectrofotômetro para leitura a $600_{\mathrm{nm}^{-}}$Ultrospec 2000 - Pharmacia Biotech

- Centrífuga para tubos $50 \mathrm{ml}$ - Juan CR3i

- Sonicador - SONIFIER 450 - Branson

3.7.2 Procedimento para preservação dos clones e teste de expressão de proteínas recombinantes em E. coli

Minipreparação das construções gênicas confirmadas foram utilizadas para a transformação de bactérias E. coli BL21(DE3)Star[pLysS]. A transformação e seleção dos clones por isolamento de colônia em placas de Agar-amp foram semelhantes aos descritos para bactérias E. coli $\mathrm{DH} 5 \alpha$. 
Os clones crescidos em meio líquido por 14 horas foram utilizados para a expressão in vitro. Aliquotas do cultivo de cada clone foram armazenadas com $15 \%$ de glicerol $(700 \mu \mathrm{l}$ de cultivo $+300 \mu$ glicerol $50 \%$ ) em freezer $-80{ }^{\circ} \mathrm{C}$.

A $\mathrm{DO}_{600 \mathrm{~nm}}$ do cultivo foi medida e preparada diluição em $30 \mathrm{ml}$ meio de cultura para $\mathrm{DO}_{600 \mathrm{~nm}} 0,2$. A cultura foi incubada a $37^{\circ} \mathrm{C}$ sob agitação até a $\mathrm{DO}_{600 \mathrm{~nm}} 0,5$, quando dividimos a cultura em dois tubos de $50 \mathrm{ml}$. Adicionamos o indutor paraquat a um dos tubos no caso de clones com vetor pAEsox, para a concentração final $150 \mathrm{mM}$. No caso de clones com vetor pAE, adicionamos IPTG para a concentração final $1 \mathrm{mM}$.

As bactérias foram induzidas por período de 5-8 horas, com agitação, a $37{ }^{\circ} \mathrm{C}$. As $\mathrm{DO}_{600 \mathrm{~nm}}$ das culturas foram medidas ao inicio e final do processo de indução.

As culturas foram centrifugadas a 2500 g por 15 minutos a $4{ }^{\circ} \mathrm{C}$ e os sobrenadantes foram descartados. Os sedimentos foram ressuspendidos em solução $\mathrm{NaCl} 100 \mathrm{mM}$ e as suspensões transferidas para tubos de 1,5 ml. As amostras foram centrifugadas por 1 minuto a $12000 \mathrm{~g}$, o sobrenadante foi novamente descartado e o precipitado celular guardado a $-20{ }^{\circ} \mathrm{C}$. Os sedimentos bacterianos receberam $600 \mu \mathrm{l}$ de solução $\mathrm{NaCl} 100 \mathrm{mM}$ e foram lisadas por quebra mecânica em um sonicador. O sobrenadante foi separado do sedimento após centrifugação a $16000 \mathrm{~g}$ por 5 minutos, obtendo-se a fração de proteínas solúveis, que ficam no sobrenadante, e fração de proteinas insolúveis, que ficam no precipitado. A dosagem das proteínas no sobrenadante foi medida por Bradford ou por leitura direta da absorbância em $280 \mathrm{~nm}$. Neste caso, consideramos que a medida de absorbância 1 corresponde a concentração de $1 \mu \mathrm{g} / \mu \mathrm{l}$.

As proteínas foram analisadas por eletroforese em gel de poliacrilamida em condições desnaturantes. As massas moleculares das proteínas recombinantes foram calculadas a partir da composição de aminoácidos, utilizando o programa Gene Runner.

\subsection{Expressão das proteínas recombinantes em salmonela}

Após a confirmação da expressão das proteínas recombinantes em E. coli BL21, transferimos os plasmideos para salmonelas competentes. Inicialmente salmonelas da linhagem SL4213 foram tranformadas pelo método do choque térmico e clones isolados em placas de agar-amp como descrito anteriormente (a passagem nessa linhagem de salmonela mutada para o sistema de reconhecimento de DNA exógeno é necessária para a transferência do DNA de E. coli para a salmonela vacinal). As colônias resultantes da transformação foram inoculadas em meio 2 YT contendo ampicilina e novobiocina para o crescimento das culturas 
e extração dos plasmideos. O DNA extraído foi utilizado na transformação de salmonelas competentes da linhagem vacinal SL3261 também por choque térmico e clones foram isolados em placas de Agar-amp.

Para verificar a expressão das proteinas recombinantes in vitro foi utilizado o mesmo método usado com as bactérias E. coli BL21(DE3)Star[pLysS].

\subsection{Dosagem de proteína pelo método de Bradford}

As concentrações de proteínas nos extratos bacterianos foram medidas segundo método de Bradford (1976).

\subsubsection{Materiais e soluções para dosagem de proteína por Bradford}

- Padrão de albumina $2 \mathrm{mg} / \mathrm{ml}$ (PIERCE)

- Coomassie Plus - Bradford Assay ${ }^{\mathrm{TM}}$ Kit (PIERCE)

- Solução $\mathrm{NaCl} 0,9 \%$

- Espectrofotômetro para leitura a 595nm - Ultrospec 2000 - Pharmacia Biotech

\subsubsection{Procedimento para dosagem de proteína}

Para a determinação da curva de calibração, utilizamos BSA (2mg/ml - Sigma) nas concentrações de 0 a $25 \mu \mathrm{g}$. As reações para dosagem foram preparadas adicionando $800 \mu \mathrm{l}$ de reagente de Bradford a $200 \mu 1$ de solução de $\mathrm{NaCl}$ 0,9\% contendo concentração conhecida de BSA ou volumes conhecidos das amostras de proteína. A absorbância das reações foi lida em espectrofotômetro em comprimento de onda $595 \mathrm{~nm}$. A partir da curva de calibração, geramos uma equação por regressão linear que foi utilizada para a análise das massas de proteínas nas amostras.

\subsection{Eletroforese em gel de poliacrilamida (SDS-PAGE)}

Amostras de extratos dos cultivos bacterianos controle ou induzidos in vitro, frações de sobrenadante ou de sedimento dos extratos foram analisadas por SDS PAGE para identificação das proteinas e a nálise da forma de expressão solúvel ou insolúvel. 


\subsubsection{Materiais e soluções para SDS PAGE}

- Acrilamida mix - acrilamida 29\%, N'N'-metilolenobisacrilamida 1\% em água milliQ

- Tampão Tris-HCl pH 8,8: tampão Tris-HCl 1,5 M e SDS 0,1\%, pH 8,8

- Tampão Tris-HCl pH 6,8: tampão Tris-HCl 0,5 M e SDS 0,1\%, pH 6,8

- TEMED - N,N,N',N'-Tetramethylethylenediamine - Sigma

- Solução de persulfato de amônio: persulfato de amônio 10\% - Sigma

- Tampão de corrida: tampão Tris-HCl 25 mM, glicina 192 mM e SDS 0,1\%, pH 8,3

- Tampão de aplicação de amostra - Tris-HCl $50 \mathrm{mM}$ pH 6,8, SDS 10\%, azul de bromofenol $0,1 \%$, glicerol $10 \%, \beta$-mercaptoetanol $100 \mathrm{mM}$ e água milliQ.

- Corante Comassie Blue R250 - Comassie blue R250 0,25\%, Ácido acético glacial $10 \%$ e Etanol $45 \%$

- Descorante - Etanol 30\%, ácido acético glacial 10\% em água milliQ

- Secante - Etanol 50\%, ácido acético glacial 10\% em água milliQ

- Cuba para eletroforese - Biorad

- Fonte para eletroforese - Eletrophoresis Power Supply EP5600 - Pharmacia Biotec

\subsubsection{Procedimento para SDS PAGE}

Amostras de extratos de cultivos bacterianos e proteínas purificadas foram analisadas por SDS-PAGE. Os géis de poliacrilamida foram preparados segundo Laemmli (1970). O gel de separação foi preparado na concentração $12,5 \%$ de poliacrilamida, ou $10 \%$ quando necessário, em tampão Tris-HCl 1,5 M pH 8,8 e SDS 0,1\%. Foi adicionado 50-75 $\mu 1$ de persulfato de amônio na concentração $10 \%$ e 3,3-5 $\mu$ l de TEMED para a polimerização do gel. O gel de empacotamento foi preparado na concentração $5 \%$ de poliacrilamida em tampão Tris-HCl 0,5 M pH 6,8, SDS 0,1\%, $25 \mu \mathrm{l}$ de persulfato de amônio 10\% e $5 \mu \mathrm{l}$ de TEMED foram adiconados para polimerização.

As amostras solúveis foram preparadas adicionando $5 \mu$ de tampão de amostra com SDS e $\beta$-mercaptoetanol a 10-15 $\mu 1$ do sobrenadante do lisado de bactérias e aquecidas a 98 ${ }^{\circ} \mathrm{C}$ por 15 minutos, para desnaturação das proteínas, sendo aplicados 15-20 $\mu \mathrm{l}$ da amostra ao gel. As amostras insolúveis foram preparadas adicionando $100 \mu 1$ de tampão de amostra com SDS e $\beta$-mercaptoetanol ao precipitado do lisado de bactérias e também aquecidas a $98{ }^{\circ} \mathrm{C}$, sendo aplicados $5 \mu \mathrm{l}$ da amostra ao gel. As corridas foram realizadas em tampão Tris-Glicina, 
aplicando corrente elétrica de $120 \mathrm{~V}$ por aproximadamente 90 minutos. Os géis foram corados com corante de Coomassie Blue por 2 horas e depois descorados.

\subsection{Purificação das proteínas recombinantes}

Após a análise dos testes de expressão das proteínas recombinantes em E. coli, partimos para a expressão em maior volume para a purificação das proteínas por cromatografia de afinidade a metal (IMAC).

\subsubsection{Materiais e soluções para purificação das proteínas}

- Centrífuga para tubos de $250 \mathrm{ml} / 500 \mathrm{ml}$ - Sorvall Evolution RC

- French Pressure - Thermo Scientific

- Solução Tampão Tris $20 \mathrm{mM}$ pH 8,0, $\mathrm{NaCl} 150 \mathrm{mM}$ com concentrações variáveis de Imidazol

- Solução de Sulfato de níquel $\left(\mathrm{NiSO}_{4}\right)$ 0,3 M

- Solução de uréia $8 \mathrm{M}$

- Colunas His trap pré empacotada - GE Amershan $1 \mathrm{ml}$ ou $5 \mathrm{ml}$

- Bomba peristáltica - Amershan Biosciences Pump P1

- Solução de $\mathrm{NaOH} 1 \mathrm{M}$

- Solução de $\mathrm{NaCl} 1,5 \mathrm{M}$

- Solução de Isopropanol 30\%

- Solução de Etanol 20\%

\subsubsection{Procedimento para purificação das proteínas por IMAC}

Após os testes de expressão em pequena escala, os clones de E. coli BL21 com as construções plasmideais confirmadas foram cultivados em $20 \mathrm{ml}$ de meio $2 \mathrm{YT}$ com ampicilina por 16 horas a $37{ }^{\circ} \mathrm{C}$. As culturas foram diluídas em $500 \mathrm{ml}$ de meio 2 YT com ampicilina e mantidas sob agitação até atingir $\mathrm{DO}_{600 \mathrm{~nm}} 0,5$, quando receberam a droga paraquat para a indução de expressão das proteínas recombinantes. A indução foi mantida por 5 horas depois as culturas foram centrifugadas a 2500 g por 10 minutos a $4{ }^{\circ} \mathrm{C}$ para a retirada do meio de cultura. O precipitado resultante da centrifugação foi ressuspendido em $50 \mathrm{ml}$ de 
solução Tris $\mathrm{HCl} 20 \mathrm{mM}$ pH 8,0, $\mathrm{NaCl} 150 \mathrm{mM}$ e Imidazol $5 \mathrm{mM}$ e foi congelado em freezer $-20{ }^{\circ} \mathrm{C}$

As suspensões bacterianas foram descongeladas e as bactérias lisadas por 3 passagens em prensa hidráulica (French Pressure - Thermo Scientific) a 1500 psi de pressão. O lisado foi centrifugado a $12000 \mathrm{~g}$ a $4{ }^{\circ} \mathrm{C}$ por 10 minutos para a separação do sobrenadante. Segundo a identificação previa de proteína expressa na forma solúvel ou insolúvel foram realzados os procedimentos para purificação a partir da fração de sobrenadante ou de sedimento.

A partir dos extratos bacterianos a proteína recombinante foi purificada por cromatografia de afinidade a metal em colunas de $1 \mathrm{~cm}$ de diâmetro com $1 \mathrm{ml}$ de resina Chelating Sepharose Fast Flow (GE-Amersham Biosciences). A resina foi lavada com $15 \mathrm{ml}$ de água milliQ, carregada com $10 \mathrm{ml}$ de solução $0,3 \mathrm{M}$ de sulfato de níquel $\left(\mathrm{NiSO}_{4}\right)$ e equilibrada com $10 \mathrm{ml}$ de tampão de entrada Tris $\mathrm{HCl} 20 \mathrm{mM}$ pH 8,0, $\mathrm{NaCl} 150 \mathrm{mM}$ e Imidazol $5 \mathrm{mM}$. A retenção da proteína recombinante na coluna ocorre pela complexação da série de 6 histidinas ao níquel imobilizado na resina. A eluição da proteína ocorre por lavagens com tampão contendo concentrações crescentes de imidazol. As moléculas de imidazol competem com as moléculas de proteína para a ligação com íon metálico.

Para as proteínas solúveis foram introduzidos na coluna, $10 \mathrm{ml} \mathrm{a} 25 \mathrm{ml}$ da fração de sobrenadante contendo a proteína recombinante, utilizando uma bomba peristáltica e velocidade de $1 \mathrm{ml} / \mathrm{min}$. Para as proteínas insolúveis, a fração de sedimento do extrato bacteriano foi incubado por 16 horas com agitação em $5 \mathrm{ml}$ de solução tampão contendo os agentes desnaturantes $8 \mathrm{M}$ de uréia e $10 \mathrm{mM}$ de $\beta$-mercaptoetanol. Após a incubação, as proteínas estavam solubilizadas e a solução foi aplicada à coluna. A concentração de Imidazol para eluição das proteínas recombinantes foi estudada e variou em função das características de cada proteína.

A concentração e a recuperação das proteínas purificadas foram analisadas por SDSPAGE. As frações com as proteínas em maior concentração e pureza foram separadas e submetidas a diálise em membrana semi-permeável de $14 \mathrm{kDa}$ contra $1 \mathrm{~L}$ de tampão fosfato (PBS) por 6 horas sob agitação. A solução foi trocada 3 vezes. As amostras dialisadas também foram analisadas por SDS-PAGE. A renaturação das proteínas insolúveis foi feita no processo de diálise, diminuindo gradativamente a concentração de uréia na amostra. Após a utilização, a coluna foi lavada seguindo as especificações do manual do fabricante, usando $\mathrm{NaOH} 1 \mathrm{M}$, $\mathrm{NaCl} 1,5 \mathrm{M}$ e isopropanol $30 \%$. A coluna foi armazena com etanol $20 \%$ a $4{ }^{\circ} \mathrm{C}$. 


\subsection{Dicroísmo circular para análise da estrutura secundária da proteína LIC10191}

A integridade da estrutura secundária da proteína LIC10191 recombinante foi analizada por dicroísmo circular (CD) em um espectropolarímetro JASCO J-810. A amostra em concentração $0,5 \mu \mathrm{g} / \mu 1$ dialisada contra PBS foi colocada em uma cubeta com $1 \mathrm{~mm}$ de espessura. As medições foram feitas nos comprimentos de onda de $190 \mathrm{~nm}$ a $260 \mathrm{~nm}$ e repetidas cinco vezes para a obtenção das médias dos valores. As temperaturas foram variadas de $2{ }^{\circ} \mathrm{C}$ a $80^{\circ} \mathrm{C}$ para testar a estabilidade da proteína.

\subsection{Imunização de camundongos e obtenção de soro}

Para a obtenção de soros com anticorpos contra as proteínas em estudo, camundongos da linhagem BALB/c, divididos em grupos de cinco animais, foram imunizados com as proteínas purificadas e com as salmonelas recombinantes. As proteínas purificadas foram injetadas via intraperitoneal, na concentração de $5 \mu$ g por dose, em $250 \mu$ de solução salina e $10 \%$ de Alhydrogel como adjuvante. Para as salmonelas recombinantes, culturas de $5 \mathrm{ml}$ contendo ampicilina foram crescidas por 16 horas a $37^{\circ} \mathrm{C}$, e então diluídas para a $\mathrm{DO}_{600 \mathrm{~nm}}$ 0,2 , o crescimento bacteriano foi acompanhado até a $\mathrm{DO}_{600 \mathrm{~nm}} 0,55$. De acordo com a literatura e com curvas de crescimento realizados em laboratório, consideramos que em $1 \mathrm{ml}$ de cultura em $\mathrm{DO}_{600 \mathrm{~nm}} 0,55$ temos $3 \times 10^{8}$ células.

Foi realizado um ensaio para teste de três diferentes vias de imunização. Para a via oral, utilizamos $3 \times 10^{9}$ células (equivalente a $10 \mathrm{ml}$ da cultura) em $50 \mu 1$ de solução salina; para a via nasal utilizamos $1,8 \times 10^{8}$ células (equivalente a $600 \mu \mathrm{l}$ da cultura) em $10 \mu \mathrm{l}$ de salina e, para via intraperitoneal, utilizamos $3 \times 10^{7}$ células (equivalente a $100 \mu 1$ da cultura) em $250 \mu \mathrm{l}$ de salina. Os volumes de cultura calculados para as doses foram separados, centrifugados a 3000 g por 15 minutos e ressuspendidos nos volumes de salina para as concentrações a serem administradas. Foram administradas quatro doses em intervalos de 15 dias. As imunizações intranasal e oral foram administradas com o auxílio de micropipetas. O segundo ensaio foi realizado para teste das salmonelas recombinantes carregando plasmideos híbridos. Neste caso, utilizamos as proteínas purificadas, as salmonelas recombinantes apresentando um único antígeno $\mathrm{e}$ as salmonelas apresentando dois antígenos simultaneamente. Todas as amostras foram administradas via intraperitoneal. Em todos os ensaios de imunização os camundongos foram sangrados pela veia retro orbital com uma pipeta Pasteur estéril, dois dias antes de cada imunização e quinze dias após a última 
imunização. O sangue de cada animal foi recolhido em tubos microtainer (BD) que possuem um gel separador. Os tubos foram incubados a TA por 1 hora, centrifugados a $12000 \mathrm{~g}$ por 1 minuto e o soro foi aliquotado para armazenamento a $-20{ }^{\circ} \mathrm{C}$.

\subsection{Teste de dose de salmonelas e recuperação de bactérias do baço de camundongos}

Realizamos um teste para analisar a toxicidade das salmonelas vacinais em camundongos, injetando variadas doses de salmonelas SL3261 carregando o vetor pAEsox sem inserto. Para tanto foi feita uma analise do crescimento das bactérias analisando os dados de DO versus unidades formadoras de colônias em placas de agar. Tornando-se o resultado de

vários ensaios, consideramos que em $1 \mathrm{ml}$ de cultura com $\mathrm{DO}_{600 \mathrm{~nm}} 0,5$ tínhamos $10^{8}$ células.

Grupos de 5 camundongos Balb/C foram imunizados por via ip com as doses $10^{8}$ bactérias ( $1 \mathrm{ml}$ da cultura), $5 \times 10^{7}$ bactérias $\left(0,5 \mathrm{ml}\right.$ da cultura), $3 \times 10^{7}$ bactérias $(0,3 \mathrm{ml}$ da cultura) e $10^{7}$ bactérias $(0,1 \mathrm{ml}$ da cultura) em solução salina. Os animais receberam apenas uma dose e foram observados durante 10 dias. Dois animais de cada grupo foram sacrificados para a retirada do baço em ambiente estéril (fluxo laminar). Os órgãos foram colocados em homogeneizadores de vidro estéreis e macerados em $1 \mathrm{ml}$ de solução salina, também estéril. Do sobrenadante de cada macerado foram plaqueados $100 \mu \mathrm{l}$ em placas $2 \mathrm{YT}$ contendo novobiocina e em placas 2 YT contendo novobiocina e ampicilina. Além disso, foi feita uma diluição 1:10 deste sobrenadante e também plaqueados $100 \mu 1$ em cada placa.

\subsection{Ensaios de imunização de hamsters e desafio com leptospiras virulentas}

Os ensaios de imunização e desafio em hamsters foram feitos em colaboração com o laboratório de zoonoses bacterianas da Faculdade de Medicina Veterinária e Zootecnia (FMVZ - USP), liderado pelo professor Dr. Silvio Arruda Vasconcellos. As imunizações e sangrias dos animais foram realizadas em colaboração com a Dra. Patrícia Estima Abreu de Aniz. Neste trabalho, foram realizados três ensaios distintos de imunização e desafio em hamsters. A seguir estão descritos características gerais dos ensaios. Detalhes específicos de cada ensaio serão apresentados juntamente com os resultados.

Utilizamos grupos de dez hamsters (Mesocricetus auratus) machos recém desmamados de aproximadamente $80 \mathrm{~g}$ marcados individualmente. As proteínas purificadas foram injetadas via intraperitoneal, na concentração de 5-25 $\mu \mathrm{g}$ por dose, em $250 \mu \mathrm{l}$ de solução salina/Alhydrogel como adjuvante. Para as salmonelas recombinantes, culturas de 5 
$\mathrm{ml}$ contendo ampicilina foram crescidas por 16 horas a $37^{\circ} \mathrm{C}$, e então diluídas para a $\mathrm{DO}_{600 \mathrm{~nm}}$ 0,2 , o crescimento bacteriano foi acompanhado até a $\mathrm{DO}_{600 \mathrm{~nm}} 0,55$. De acordo com a literatura e com curvas de crescimento realizados em laboratório, foi considerado que em $1 \mathrm{ml}$ de cultura temos $3 \times 10^{8}$ células. As salmonelas recombinantes foram injetadas via intraperitoneal de $3 \times 10^{7}$ a $5 \times 10^{7}$ células em $250 \mu$ de solução salina, a cultura foi centrifugada a $3000 \mathrm{~g}$ por 15 minutos e ressuspendida em $250 \mu \mathrm{l}$ de salina/tampão fosfato. Utilizamos salmonela carregando o vetor vazio como controle negativo. Usamos ainda um grupo controle negativo imunizado apenas com salina/Alhydrogel e um grupo controle positivo imunizado com a vacina comercial FarrowSure $^{\circledR}$ B da Pfizer. Essa vacina é indicada contra Erisipela, Leptospirose (causada pelos sorotipos L. bratislava, L. canicola, L. grippotyphosa, L. hardjo, L. icterohaemorrhagiae e L. pomona) e Parvovirose dos suínos. Para a imunização dos hamsters diluímos a vacina 1:800 em solução salina e injetamos $200 \mu 1$ por animal. Em geral foram feitas três imunizações via intraperitoneal com intervalo de quinze a vinte e um dias entre cada uma. As sangrias foram feitas individualmente por punção da veia retrorbital do olho dos animais utilizando pipetas Pasteur estéreis. Os grupos de imunização e as doses administradas em cada ensaio realizado estão apresentadas com os resultados.

Para o ensaio de desafio utilizamos a cepa Leptospira interrogans sorovar Pomona ou Leptospira interrogans sorovar Copenhageni. O desafio dos animais nos três ensaios realizados sofreu algumas variações devido a diferenças na virulência, no crescimento e na morfologia entre as duas cepas. Como protocolo usual de desafio com a Leptospira interrogans sorovar Pomona, o fígado de um animal infectado foi extraído e macerado em 9 $\mathrm{ml}$ de meio de cultura EMJH. Deste macerado, uma alíquota de $10 \mu 1$ foi colocada em uma lâmina para contagem das bactérias em microscópio de campo escuro com aumento de 200X.

A quantidade de leptospiras no inóculo inicial, quando observadas em lâmina comum, foi calculada segundo a fórmula:

\section{Número de leptospiras $=$ soma leptospiras nos cinco campos $X \mathrm{fd} X \mathrm{X} X \mathrm{~b}$ $\mathrm{mL}$ de suspensão inicial}

Sendo, $\mathbf{f d}=$ fator de diluição

$\mathbf{a}=100$, pois os 5 campos correspondem a $1 / 100$ do volume total da amostra na lâmina

$$
\mathbf{b}=100 \text { pois } 10 \mu \mathrm{l} \text { é } 1 / 100 \text { do } \mathrm{ml}
$$


O desafio com a Leptospira interrogans sorovar Copenhageni sofreu algumas variações, pois foi dependente do número de bactérias na cultura e dos repiques definindo as passagens em cultura.

Resumidamente, animais infectados experimentalmente com a bactéria e apresentando os sintomas de leptospirose foram sacrificados e o fígado macerado em meio EMJH. A cultura foi mantida a $30{ }^{\circ} \mathrm{C}$ por sete dias. A passagem em cultura desta cepa é necessária para permitir o crescimento bacteriano e possibilitar a contagem em microscópio. Fizemos a contagem das bactérias em lâmina normal e também em câmara de Petroff-Hausser. A Figura 7 mostra um desenho esquemático da câmara de Petroff-Hausser, a divisão da área em quadrados de tamanhos iguais facilita a contagem e o cálculo final.

O número de bactérias no inóculo inicial após a contagem em câmara de PetroffHausser foi calculado segundo a fórmula:
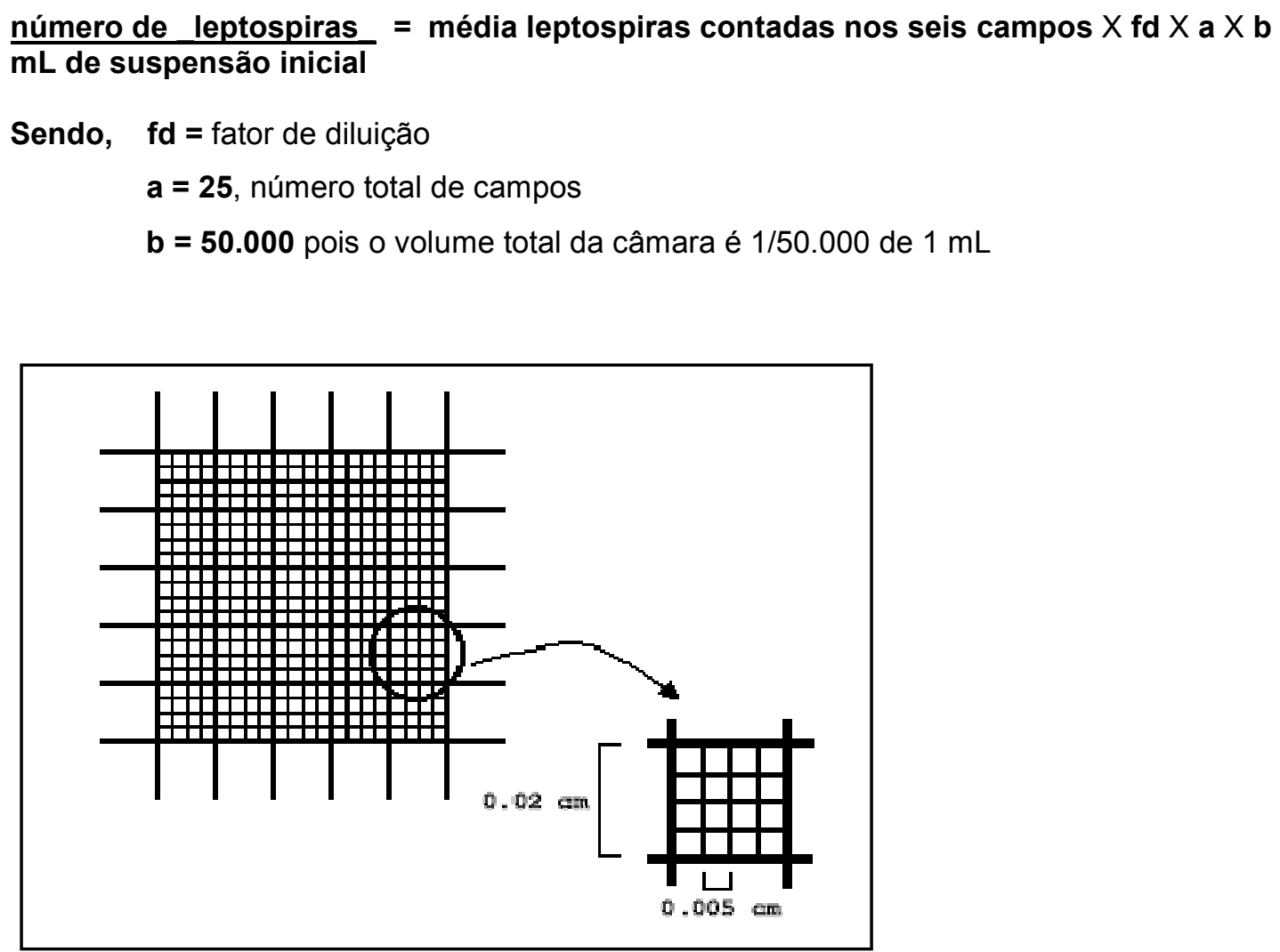

Figura 7 - Modelo esquemático do desenho da área de contagem de bactérias na câmara de Petroff-Hausser.

Após o desafio, os animais foram observados durante 21 dias e os sobreviventes foram sangrados e sacrificados. O soro obtido foi utilizado no teste de MAT e em ensaios de ELISA e western blot. 
A possível adaptação dos animais sobreviventes à leptospira foi avaliada por recuperação da bactéria dos rins dos animais. Para isso os rins foram extraídos, pesados, macerados e diluídos (1:1000) com salina de Sorensen. Uma alíquota (3 gotas) das diluições dos macerados de rins de cada animal foi colocada em $10 \mathrm{ml}$ de meio de EMJH e a solução mantida a $30{ }^{\circ} \mathrm{C}$ por seis semanas para observação qualitativamente de crescimento de leptospiras.

\subsection{ELISA para análise de resposta humoral em camundongos e hamsters imunizados}

Os soros dos camundongos e hamsters imunizados foram analisados quanto a indução de anticorpos IgG específicos contra as proteínas recombinantes por ELISA (Enzyme-Linked Immunosorbent Assay).

\subsubsection{Materiais e soluções para ELISA}

- Microplacas de fundo chato 96 poços: Nunc-MaxiSorp ${ }^{\mathrm{TM}}$-USA

- $\mathrm{PBS}$ - NaCl 137 mM, KCl 1,68 mM, $\mathrm{Na}_{2} \mathrm{HPO}_{4}$ 8,1 mM, $\mathrm{KH}_{2} \mathrm{PO}_{4} 1,47 \mathrm{mM}$ pH 7,0

- Solução de lavagem - PBS com 0,05\% tween (PBST)

- Solução de bloqueio - PBST com leite desnatado $10 \%$ e BSA $1 \%$

- Solução carbonato de sódio 0,1 M/ bicarbonato de sódio 0,1 M pH 9,2

- Solução citrato de sódio $0,1 \mathrm{M} /$ fosfato de sódio $0,2 \mathrm{M}$ pH 5,0

- Anticorpos secundários:

○ anti-IgG camundongo produzido em coelhos conjugado com peroxidase PIERCE

○ anti-IgG $(\mathrm{H}+\mathrm{L})$ hamster produzido em cabra conjugado com peroxidase KPL

- Lavadora de placas - Wellwash 4 MK 2 - Thermo Scientific

- Leitor de placas - Multiskan EX - Thermo Scientific

- Solução de revelação: OPD 0,05\% e $\mathrm{H}_{2} \mathrm{O}_{2}$ 0,015\%, em tampão citrato $\mathrm{pH} 5,0$

- Solução para interromper a revelação: ácido sulfúrico 4 N 


\subsubsection{Procedimento para ELISA}

As placas foram sensibilizadas com as proteínas purificadas por IMAC na concentração de $5 \mu \mathrm{g} / \mathrm{ml}$ em tampão carbonato/bicarbonato $0,1 \mathrm{M} \mathrm{pH} \mathrm{9,6} \mathrm{ou} \mathrm{PBS} \mathrm{e} \mathrm{incubadas}$ à $4{ }^{\circ} \mathrm{C}$ por 18 horas. As placas foram lavadas 3 vezes com solução de lavagem (PBS/Tween 20 0,05\%), bloqueadas com leite em pó desnatado 10\% (MOLICO) e BSA 1\% em solução PBS/Tween $200,05 \%$ e incubadas por pelo menos 2 horas à $37^{\circ} \mathrm{C}$.

Após o bloqueio, o soro de animais imunizados com as proteínas purificadas ou com as salmonelas recombinantes foi adicionado. A partir do primeiro poço diluições seriadas foram feitas em tampão PBS/Tween 20 0,05\% com leite em pó desnatado 5\%. Em seguida, a placas foram incubadas a $37^{\circ} \mathrm{C}$ por 2 horas e lavadas 3 vezes com solução de lavagem. As placas foram incubadas novamente por 2 horas à $37{ }^{\circ} \mathrm{C}$ com o anticorpo anti-IgG de camundongos (PIERCE) ou anti-IgG hamsters (KPL) conjugado com peroxidade em tampão PBS/Tween 20 0,05\%/ leite em pó desnatado 10\%. Após a incubação do anticorpo conjugado, as placas foram novamente lavadas e reveladas com a solução reveladora contendo ortofenilenodiamina (OPD) em tampão citrato/fosfato $0,1 \mathrm{M} \mathrm{pH} \mathrm{5,0.} \mathrm{Para} \mathrm{parar} \mathrm{a} \mathrm{reação} \mathrm{usamos}$ uma solução ácida forte, $\mathrm{H}_{2} \mathrm{SO}_{4} 4,5 \mathrm{M}$ ou $\mathrm{HCl} 3 \mathrm{M}$. A coloração amarelada gerada pela reação de revelação é lida no comprimento de onda $492 \mathrm{~nm}$ em um leitor de placas, utilizou-se como branco da reação os poços da placa que receberam todas as soluções descritas com exceção do soro. Consideramos o título de anticorpo IgG para cada soro, o inverso da diluição na qual obtivemos absorbância 0,1 após a leitura das placas no comprimento de onda $492 \mathrm{~nm}$.

\subsection{Western blot para análise de reconhecimento do antígeno pelo soro}

Analisamos a especificidade do reconhecimento das proteínas recombinantes pelos anticorpos IgG no soro dos camundongos e hamsters imunizados, por western blot.

\subsubsection{Materiais e soluções para western blot}

- Membranas de PVDF - Immobilon P - Millipore

- Solução TBS (solução basal) - NaCl 150mM, Tris Base 10 mM pH 7,4 e tween 0,05\%

- Tampão de transferência - Tris base 25 mM pH8,0, glicina $192 \mathrm{mM}$, SDS 0,02\% e metanol $20 \%$ 
- Corante de Ponceau: Ponceau S 0,5\%, ácido acético glacial 10\% e água milliQ

- Solução de bloqueio: leite desnatado 10\%, BSA 1\% em solução TBS

- Solução de revelação - Tris $60 \mathrm{mM}, 0,7 \mathrm{mg} / \mathrm{ml}$ diaminobenzidina (DAB), 0,7 mg/ml peróxido de hidrogênio $\left(\mathrm{H}_{2} \mathrm{O}_{2}\right)$ e uréia $2 \mathrm{mg} / \mathrm{mL}$ - Sigma (D4293 - 50SET).

- Anticorpo secundário:

○ anti-IgG camundongo produzido em coelhos conjugado com peroxidase PIERCE

○ anti-IgG $(\mathrm{H}+\mathrm{L})$ hamster produzido em cabra conjugado com peroxidase $-\mathrm{KPL}$

○ anti-IgG humano produzido em cabra conjugado com peroxidase - KPL

$\circ$ anti-IgM $(\mu)$ humano produzido em cabra conjugado com peroxidase - KPL

\subsubsection{Procedimento para western blot}

Para avaliar a presença de anticorpos específicos nos soros, as proteínas foram separadas por SDS-PAGE e transferidas para membranas de PVDF. A transferência foi realizada pela passagem de corrente elétrica de $350 \mathrm{~mA}$ por aproximadamente 90 minutos em gelo. O tempo de transferência está diretamente relacionado com o tamanho da proteína, quanto menor a massa molecular mais fácil a proteína é transferida. Para avaliar a qualidade da transferência, as membranas foram coradas com solução de Ponceau S para a visualização das bandas de proteína. As membranas foram lavadas com água e bloqueadas com solução TBS-T com $10 \%$ de leite em pó desnatado, sendo incubadas por aproximadamente 3 horas com agitação em TA.

Após o bloqueio, as membranas foram incubadas com a mesma solução contendo o primeiro anticorpo, que consiste no soro obtido dos camundongos ou hamsters. A diluição do soro dependeu da titulação do ELISA, em geral, foi feita a diluição 1:1000. As membranas foram incubadas com a solução de anticorpos por 14 horas a $4{ }^{\circ} \mathrm{C}$ com agitação. As membranas foram lavadas 4 vezes de 10 minutos cada com solução de TBST. O segundo anticorpo conjugado com peroxidase foi adicionado na solução de bloqueio na diluição apropriada sugerida pelo fabricante e as membranas foram incubadas por 2 horas a TA sob agitação.

As membranas foram lavadas 4 vezes por 10 minutos cada, e as bandas de reconhecimento reveladas utilizando dimetiamino benzidina (DAB). A solução de revelação foi preparada por dissolução de DAB (Sigma) em $5 \mathrm{ml}$ de água para concentrações finais de 
tampão tris $60 \mathrm{mM}$ e DAB $0,7 \mathrm{mg} / \mathrm{ml}$ e um comprimido de uréia (Sigma) para concentrações finais $2 \mathrm{mg} / \mathrm{ml}$ de uréia e $0,7 \mathrm{mg} / \mathrm{ml} \mathrm{de} \mathrm{H}_{2} \mathrm{O}_{2}$. As membranas foram incubadas com a solução de revelação até o aparecimento das bandas (10 a 30 minutos) e então lavadas com água. 


\section{RESULTADOS}

\subsection{Caracterização dos antígenos selecionados}

Para seleção de antígenos de leptospira a serem estudados, utilizando programas de bioinformática, avaliamos os genes e as proteinas preditas quanto a características sugestivas de potencial vacinal, como proteinas secretadas ou localizadas na membrana externa, portanto expostas ao sistema imune.

A despeito de termos estudado inicialmente outros genes, apresentamos aqui as características daqueles antígenos que trabalhamos nos ensaios de imunização, correspondentes aos genes LIC10191, LIC10793, LIC12302, LIC11227 e LIC13101. Ao final foram incluídos também os antígenos que apresentavam resultados de proteção positivos na literatura e em trabalhos realizados pelo grupo, LIC11352 (Lip32), LIC10325 (HlyX), LIC10465 (LigA) e LIC12033 (ankB). Apresentamos aqui a caracterização parcial dos antígenos feita por análise bioinformática, bem como alguns dados da literatura.

\section{$\underline{\operatorname{LIC10191}(\operatorname{Loa22})}$}

A proteína LIC10191, denominada Loa22 (KOIZUMI e WATANABE, 2003), foi anotada no genoma da L. interrogans sorovar Copenhageni como uma proteína de membrana associada a peptideoglicano, o gene possui 588 pares de bases. A analise in silico prediz um peptídeo sinal e um domínio OmpA-like - outer membrane protein (Figura 8).

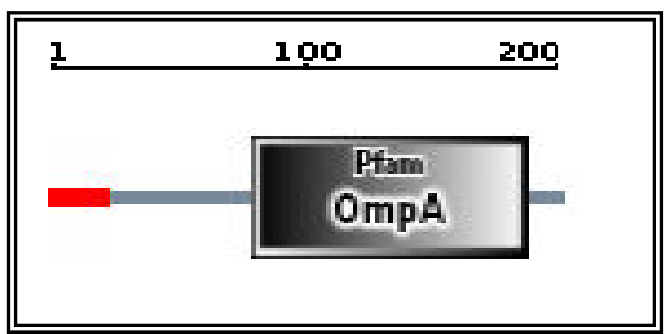

Figura 8 - Esquema da localização do motivo OmpA encontrado na proteína LIC10191. Domínio OmpA da proteína entre os aminoácidos 77 e 182 e peptídeo sinal indicado em vermelho sugerido pelo programa SMART.

Uma função prevista da OmpA seria promover a ligação entre a membrana externa e a camada mais interna de peptideoglicano do periplasma. Seria uma função essencial na manutenção da integridade da superfície celular da bactéria (KOIZUMI e WATANABE, 2003). Essa proteína estaria exposta na superfície de bactérias patogênicas, e não foi observada em bactérias não patogênicas como L. biflexa e L. meyeri em ensaios de western 
blot. A correlação entre a patogenicidade de linhagens da bactéria e a presença da proteína sugere que esta esteja envolvida com a virulência (GAMBERINI et al., 2005). Mais evidencias da participação de Loa22 na virulência de leptospiras foram mostradas por ensaios de imunoblot (KOIZUMI e WATANABE, 2003) e imunofluorescência (RISTOW et al., 2007). Foi mostrado que a expressão da proteína é aumentada durante infecção (NALLY et al., 2005). Estudos recentes mostraram que a bactéria com deleção no gene da Loa22 perde a virulência e a capacidade de induzir a morte em cobaias (RISTOW et al., 2007).

Entretanto, blast no banco de dados de proteínas indicam que existe uma proteína ortóloga a LIC10191 na linhagem biflexa que apresenta 73\% de similaridade. A presença de uma proteína similar a LIC10191 em espécies saprófitas sugere que ela pode estar envolvida na sobrevivência e não na virulência da bactéria. Ambas proteínas podem ter se originado de um mesmo ancestral (PICARDEAU et al., 2008).

Em bactérias Gram-negativas, proteínas OmpA tem sido caracterizadas como adesinas (DABO et al., 2003). De fato, a proteína Loa22 recombinante possui a capacidade de se ligar aos componentes da matriz extracelular como fibronectina plasmática e colágenos tipo I e IV (BARBOSA et al., 2006).

\section{$\underline{\text { LIC10793 (Lp49) }}$}

A proteina LIC10793 de $49 \mathrm{kDa}$ foi descrita como uma lipoproteína Lp49 (GIUSEPE et al., 2008), não sendo identificados domínios funcionais. A proteína está presente nas linhagens patogênicas e ausente nas linhagens não patogênicas (NEVES et al., 2007). Este dado pode ser confirmado por Blast da sequência de aminoacidos com as proteínas previstas nos genomas sequenciados de outras leptospiras. Neste mesmo estudo foi mostrado que esta proteína é reconhecida por anticorpos presentes no soro de pacientes no estágio inicial da doença, quando o teste de MAT ainda tem resultado negativo. Apesar dos baixos títulos gerados em testes de ELISA, essa proteína pode ser considerada candidata a testes de diagnóstico. A análise da estrutura secundária da proteína Lp49 mostrou a predominância de estrutura folha $\beta$ com uma mistura de enovelamentos randômicos e regiões de $\alpha$ hélice (NEVES et al., 2007).

\section{$\underline{\operatorname{LIC11227}}$}

O gene LIC11227 codifica uma proteína hipotética de $28 \mathrm{kDa}$ com função desconhecida. O alinhamento da sequência de nucleotídeos com genoma de outras leptospiras mostra que o gene é conservado na Leptospira interrogans sorovar Lai. 


\section{$\underline{\text { LIC12302 }}$}

O gene LIC12302 codifica uma proteína que possui um domínio peptidase_M22, pertencente ao grupo das metalopeptidases (Figura 9). O exemplo típico é a Osialoglicoproteína endopeptidase de Pasteurella haemolytica descrita por Sutherland et al., 1992. Neste estudo, foi comprovado que essa proteína possui a capacidade de clivar Osialoglicoproteinas encontradas na superfície de células humanas CD34, CD43, CD44 e CD45.

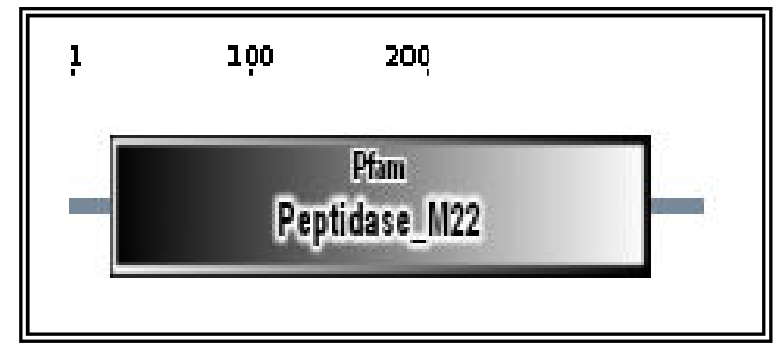

Figura 9 - Esquema da localização do motivo peptidase_M22 encontrado na proteína LIC12302. Domínio Peptidase_M22 da proteína entre os aminoácidos 23 e 311, sugerido pelo programa SMART.

O gene está presente nos genomas das espécies patogênicas Leptospira interrogans sorovar Lai e Leptospira borgpetersenii sorovar Hardjo-bovis e também na estirpe não virulenta Leptospira biflexa sorovar Patoc.

\section{$\underline{\operatorname{LIC13101}}$}

O gene LIC13101 codifica uma proteína de 127 kDa com sequência sinal no início, duas regiões de repetições internas intercaladas por regiões de baixa complexidade e 7 dominios de alpha integrina (Figura 10). Integrinas são moléculas de adesão celular que mediam a matrix extracelular a as interações entre as células. Elas possuem as subunidades alpha e beta. As alpha integrinas possuem um domínio contendo 7 regiões de repetição que adota uma conformação "beta-propellor". Alguns desses domínios contem um domínio do fator de Von Willebrand tipo-A. Algumas repetições contem sítios putativos de ligação a cálcio. O domínio contendo 7 regiões de repetição é homologo a um domínio da fosfatidilinositol-glicano-especifico da fosfolipase D. 


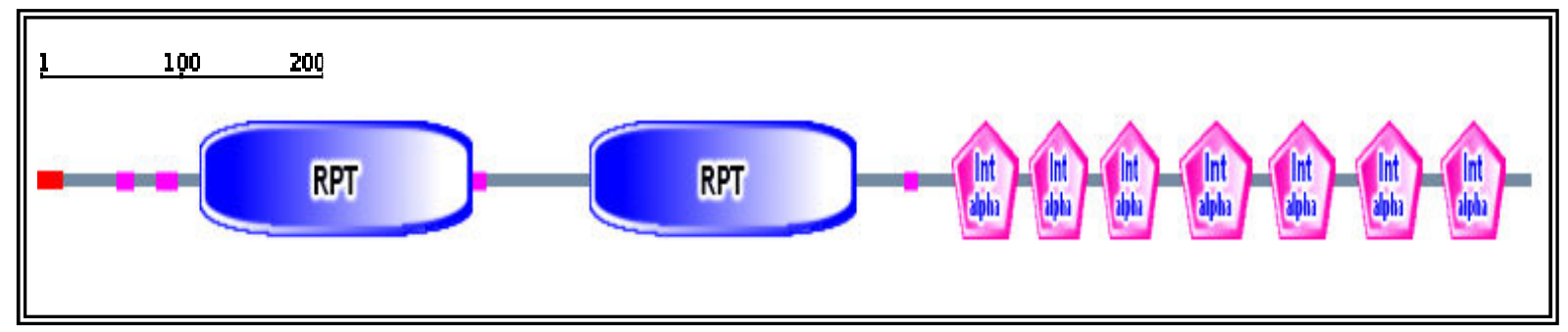

Figura 10 - Esquema da localização dos motivos alfa integrina encontrados na proteína LIC13101. Dois domínios de repetição interna com função desconhecida, sete domínios de alfa integrina e peptídeo sinal indicado em vermelho sugerido pelo programa SMART.

A sequência do gene foi comparada com genomas seqüenciados de outras Leptospiras e encontramos alta identidade de pares de bases com um gene de Leptospira interrogans sorovar Lai. Não encontramos genes similares a LIC13101 no genoma da Leptospira biflexa sorovar Patoc.

\section{$\underline{\text { LIC11352 (Lip32) }}$}

A proteína LIC11352, denominada Lip32, foi anotada no genoma da Leptospira interrogans sorovar Copenhageni como uma lipoproteína. Não foram identificados domínios funcionais nesta proteína, apenas um peptídeo sinal. Esta proteína foi descrita como a mais abundante na superfície da bactéria e importante durante a infecção (HAAKE et al., 2000). É conservada entre as espécies patogênicas de Leptospira, mas não há ortólogos nas linhagens não patogênicas. Mostrou-se bastante imunogênica e foi reconhecida por soro de pacientes infectados (GUERREIRO et al., 2001).

\section{$\underline{\operatorname{LIC10325}(\mathrm{HlyX})}$}

A proteína LIC10325, denominada HlyX foi anotada no genoma da Leptospira interrogans sorovar Copenhageni como uma hemolisina contendo 5 dominios TPR repetidos (Figura 11). Esse domínio pode ser encontrado em inúmeras proteínas e é responsável por mediar interações entre proteínas e estruturar complexos protéicos. Essa proteína pode exercer papel importante na patogenicidade da bactéria, uma vez que causou hemólise em eritrócitos in vitro. Além disso, ortólogos desta proteína foram encontrados nas leptospiras virulentas, Leptospira interrogans sorovar Lai e Leptospira borgpetersenii sorovar hardjobovis (HAUK et al., 2005). 


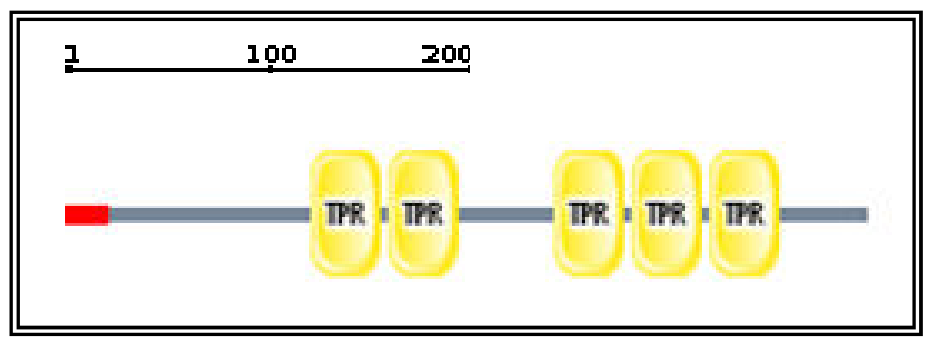

Figura 11 - Esquema da localização dos motivos TPR encontrados na proteína LIC10325. Os 5 domínios TPR da proteína estão entre os aminoácidos 115 e 337 e o peptídeo sinal está indicado em vermelho sugerido pelo programa SMART.

\section{$\underline{\operatorname{LIC} 10465(\operatorname{LigA})}$}

Essas proteínas possuem domínios de aproximadamente 85 aminoácidos similares a imunoglobulinas de bactérias (Figura 12). Segundo Choy et al. (2007) essas proteínas têm a capacidade de se ligar a proteínas da matriz extracelular e a fibrinogênio sugerindo que essas adesinas devem estar envolvidas a colonização inicial e disseminação das leptospiras no hospedeiro. A proteína nativa possui aproximadamente $128 \mathrm{kda}$, proteínas de alto peso molecular são geralmente difíceis de purificar. Entretanto, neste trabalho, clonamos apenas o fragmento c da proteína de aproximadamente 44 kda. Segundo Silva et al. (2007), a porção carboxi-terminal da proteína foi capaz de induzir proteção contra infecção em hamsters imunizados. Esta proteína não foi identificada nos genomas da Leptospira interrogans sorovar Lai e Leptospira borgpetersenii sorovar Hardjo (McBRIDE et al., 2009) porém os domínios big desta proteína possui alta identidade com domínios da LigB, encontrada em outras leptospiras virulentas (SILVA et al., 2007).

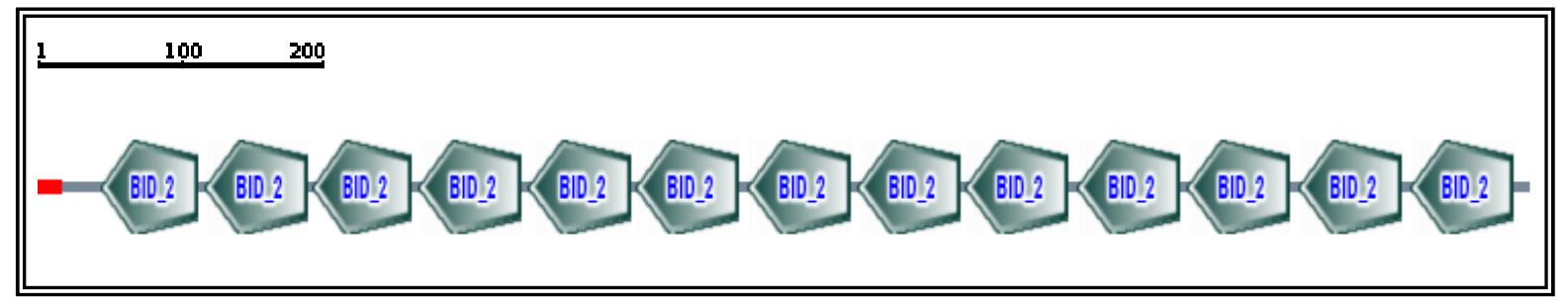

Figura 12 - Esquema da localização dos motivos BID encontrado na proteína LIC10465. Os 13 domínios BID da proteína possuem aproximadamente 85 aminoácidos, existe ainda um peptídeo sinal, indicado em vermelho sugerido pelo programa SMART.

\section{$\underline{\text { LIC12033 (ankB) }}$}

A proteína ankB de Leptospira interrogans sorovar Copenhageni possui duas repetições ankirina (Figura 13). O gene está presente nos genomas das espécies patogênicas Leptospira interrogans sorovar Lai e Leptospira borgpetersenii sorovar Hardjo-bovis. Os 
domínios ankirina são encontrados, em células eucarióticas, em proteínas do citoesqueleto que ancoram proteínas na membrana (GORINA e PAVLETICH, 1996). O gene de ankirina é vizinho do gene de catalase em diferentes microrganismos sugerindo expressão composta e possivelmente importante durante infecção, como resposta ao extresse oxidativo imposto pelo sistema imune.

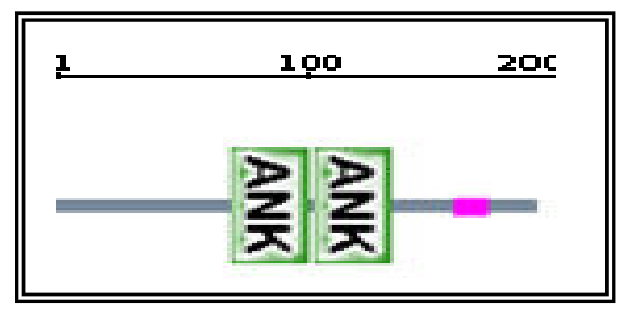

Figura 13 - Esquema da localização dos motivos ank encontrado na proteína LIC12033. Existem dois domínios ank localizados entre os aminoácidos 65 e 127. Existe ainda uma região de baixa complexidade entre os aminoácidos 150 e 163 indicado em vermelho sugerido pelo programa SMART.

\subsection{Clonagem dos genes}

\subsubsection{Amplificação dos genes e clonagem em vetor pGEMT-Easy}

Após a escolha dos genes de leptospira a serem estudados, os "primers" foram desenhados com auxilio do programa "GENERUNNER" e iniciamos a fase de amplificação destes genes usando DNA genômico da Leptospira interrogans sorovar Copenhageni como molde. Em princípio, dez genes, LIC10191, LIC10793, LIC12302, LIC12659, LIC10537, LIC11227, LIC10508, LIC10868, LIC12033 e LIC13101 foram amplificados por PCR como ilustrado na Figura 14.

Os produtos de PCR foram ligados em vetor pGem-T Easy e usados na transformação de E. coli DH5a. Os clones com as construções de interesse foram selecionados por resistência a ampicilina e verificados por teste de fenol-clorofórmio. Preparações plasmidiais desses clones foram analisadas por digestão com enzimas de restrição apropriadas (Figura 15) e confirmados por sequenciamento de DNA. Após a confirmação de cada construção, os plasmídeos foram digeridos utilizando os sítios de restrição adicionados nos primers. As duplas digestões liberaram os fragmentos gênicos, que foram purificados de um gel de agarose e utlizados para ligação nos vetores de expressão. 


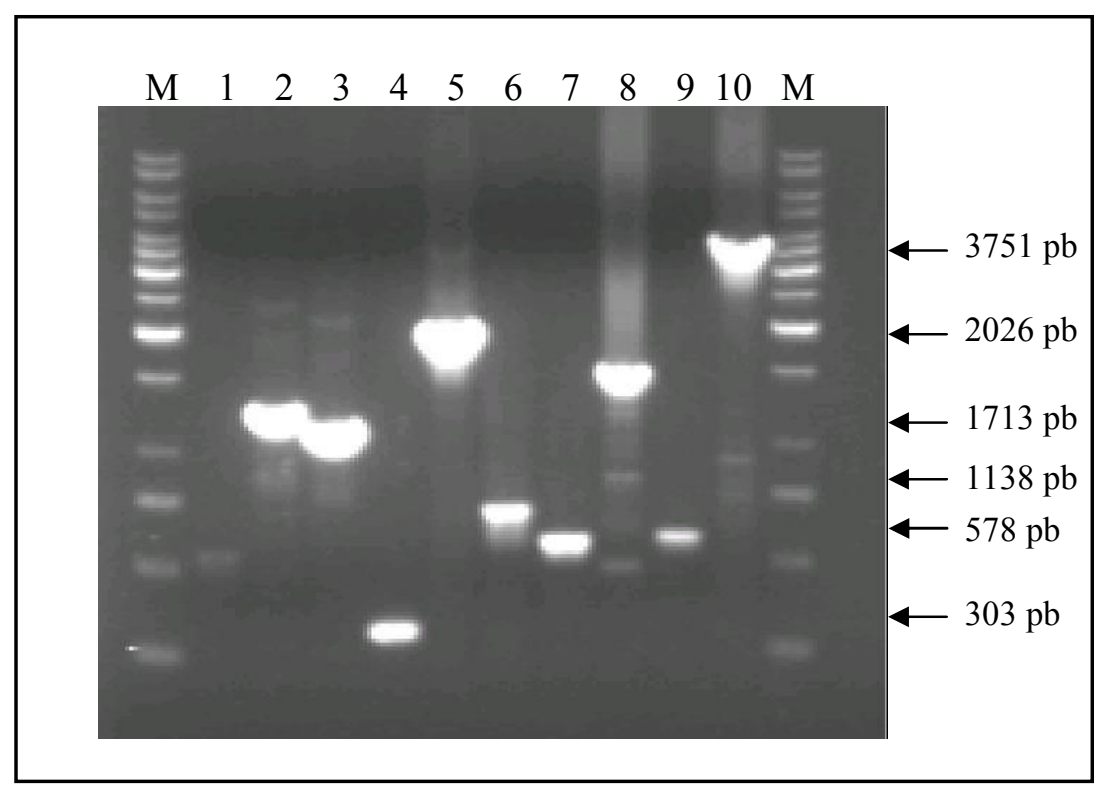

Figura 14 - Análise dos produtos das amplificações gênicas por PCR em gel de agarose. Mmarcador molecular (1 kb - Fermentas). Canaletas: 1- LIC10191 (536 pb); 2- LIC10793 (1275 pb); 3- LIC12302 (1138 pb); 4- LIC12659 (303 pb); 5- LIC10537 (2026 pb); 6LIC11227 (692 pb); 7- LIC10508 (563 pb); 8- LIC10868 (1713 pb); 9- LIC12033 (578 pb); 10- LIC13101 (3751 pb).

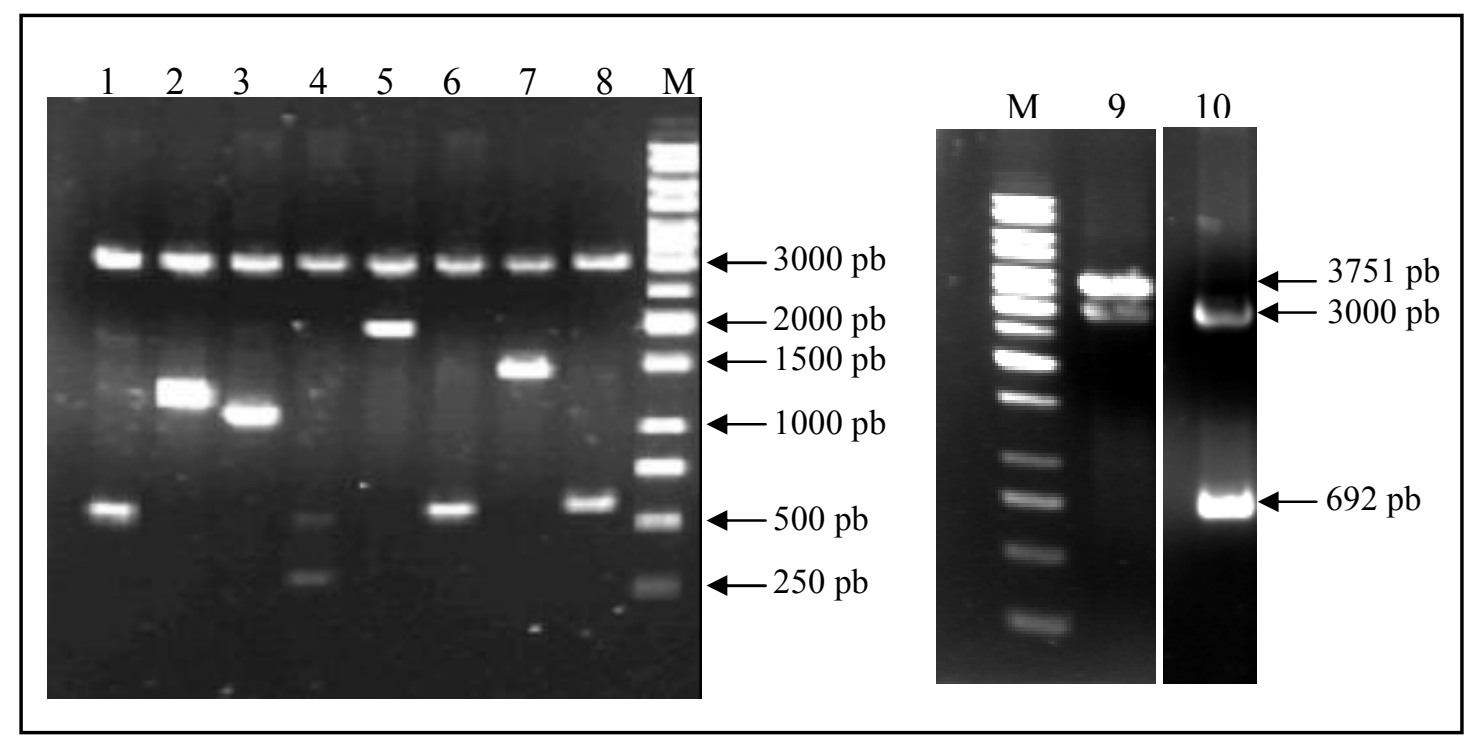

Figura 15 - Análise dos clones com genes de leptospira em vetor pGEM-T Easy por digestão com enzimas de restrição. $\mathrm{M}$ - marcador molecular. Os plasmídoes foram digeridos com as enzimas BamHI e HindIII, exceto a LIC10191, que foi digerida com BamHI e PstI. Canaletas: 1 a 8 a banda de $\sim 3 \mathrm{kpb}$ corresponde ao vetor pGEM-T Easy. Os fragmentos de DNA menores correspondem aos diferentes genes. Canaletas: 1- LIC10191 (536 pb); 2- LIC10793 (1275 pb); 3- LIC12302 (1138 pb); 4- LIC12659 (303 pb); 5- LIC10537 (2026 pb); 6- LIC10508 (563 pb); 7- LIC10868 (1713 pb); 8- LIC12033 (578 pb) e 9LIC13101 (3751 pb) e 10- LIC11227 (692 pb). 


\subsubsection{Clonagem dos genes de leptospira nos vetores $\mathrm{p} A E$ e pAEsox}

Os fragmentos gênicos de interesse obtidos por duplas digestões das construções em vetor pGEMT-Easy com enzimas de restrição previstas nos primers, foram usados para subclonagem nos vetores pAE e pAEsox. Nesta etapa do trabalho, passamos a trabalhar com cinco genes para a inserção nos vetores de expressão, LIC10191, LIC10793, LIC12302, LIC11227 e LIC13101, enquanto os outros genes se tornaram objeto de estudos de colegas do laboratório. Quatro dos genes foram obtidos por digestão com BamHI e HindIII e o gene LIC10191 foi digerido com BamHI e PstI. Os genes foram inseridos nos vetores pAE e pAEsox, digeridos com as mesmas enzimas. Amostras das reações de ligação foram usadas para transformar bactérias $E$. coli DH5 . Os clones foram selecionados por resistência a ampicilina e analisados por fenol:clorofórmio. Para a confirmação das construções fizemos testes de digestão com uma pequena alíquota das minipreparações e visualizamos as amostras em gel de agarose (Figura 16). Os plasmideos pAE e pAEsox contendo os genes LIC10793, LIC12302, LIC11227 e LIC13101 foram digeridos com as enzimas BamHI e HindIII, liberando dois fragmentos, o gene e o vetor. Os plasmídeos pAE e pAEsox contendo o gene LIC10191 foram digeridos apenas com a enzima HindIII, pois existe sítio para essa enzima no final do gene e no vetor, liberando um fragmento de $171 \mathrm{pb}$ e outro de $3625 \mathrm{pb}$ (pAEsox) ou 3205 pb (pAE). Após a confirmação, as construções foram utilizadas para transformação das bactérias BL21 para expressão e produção dos antígenos. Os clones selecionados foram mantidos a $-80{ }^{\circ} \mathrm{C}$ com $15 \%$ de glicerol.

Além dos cinco genes citados acima, também transferimos para vetores pAE e pAEsox os genes LIC10325 (HlyX) e LIC11352 (Lip32) que já haviam sido clonados durante a fase inicial do projeto genoma da leptospira em vetor pDest em E. coli DH5a. O gene LIC10325 já havia sido transferido para o vetor pAE e transformado em bactéria $E$. coli $\mathrm{DH} 5 \alpha$ pelo grupo colaborador liderado pelo Dr. Paulo Lee Ho. Esses clones foram cultivados em meio liquido para a extração do DNA plamidial. As preparações plasmidiais foram digeridas com enzimas de restrição para subclonagens. O vetor pAELIC10325 foi digerido com as enzimas NdeI e EcoRI gerando fragmentos de aproximadamente $1137 \mathrm{pb}$, que corresponde ao gene de interesse, e um de $2800 \mathrm{pb}$ corresponde ao vetor pAE. O vetor pDestLIC11352 foi digerido com as enzimas NdeI e HindIII gerando os fragmentos de aproximadamente 819 pb e 5000 $\mathrm{pb}$, correspondentes ao fragmento de interesse e do vetor respectivamente. Na Figura 17 amostras dos plasmideos e das digestões enzimáticas foram analisadas em gel de agarose. 
Para a clonagem dos insertos, amostras do vetor pAEsox foram digeridas com as mesmas duplas de enzimas, NdeI e EcoRI ou NdeI e HindIII, gerando fragmentos de $3200 \mathrm{pb}$ (Figura 17).

As reações de ligação dos genes LIC11352 e LIC10325 com o vetor pAEsox foram utilizadas para transformar bactérias E. coli DH5a competentes. Poucos clones foram recuperados e foram utilizados em reações de PCR para a confirmação da presença do inserto. Clones foram escolhidos para crescimento e purificação de plasmideos. Amostras das minipreparações foram digeridas com enzimas $X b a \mathrm{I}$ e HindIII para confirmação de presença de inserto. Na Figura 18, linhas 2 e 4, pode-se observar as bandas de 2720 pb, 1274 pb e 330 pb geradas por digestão do vetor pAEsoxLIC10325. Neste caso foi possível visualizar três bandas distintas, pois existem dois sítios de restrição para a enzima HindIII, um dentro do gene e o outro no vetor. Na figura 12 linha 5 pode-se observar as bandas resultantes da dupla digestão do plasmídeo pAEsoxLIC11352, sendo que a banda maior, 2840 pb, corresponde ao vetor $\mathrm{pAE}$ e a banda menor, $1279 \mathrm{pb}$ corresponde ao gene de interesse mais o fragmento soxRpsoxS.

Neste projeto também clonamos parte do gene LIC10465 (LigA) em salmonela. O fragmento do gene codificador da porção C-terminal da proteína havia sido clonado pela estudante de doutorado Vivian Hashimoto, do grupo colaborador liderado pelo Dr. Paulo Lee Ho. O fragmento já digerido com as enzimas $X h o \mathrm{I}$ e $P s t \mathrm{I}$ foi ligado ao vetor pAEsox digerido com as mesmas enzimas. A reação de ligação foi utilizada para transformar bactérias $E$. coli DH5 $\alpha$ competentes. Alguns clones foram isolados da placa e cultivados para um teste de fenol:clorofórmio. Fizemos miniprep de um dos clones positivos e confirmamos a presença do inserto por digestão com as enzimas $X b a \mathrm{I}$ e XhoI (Figura 19). 


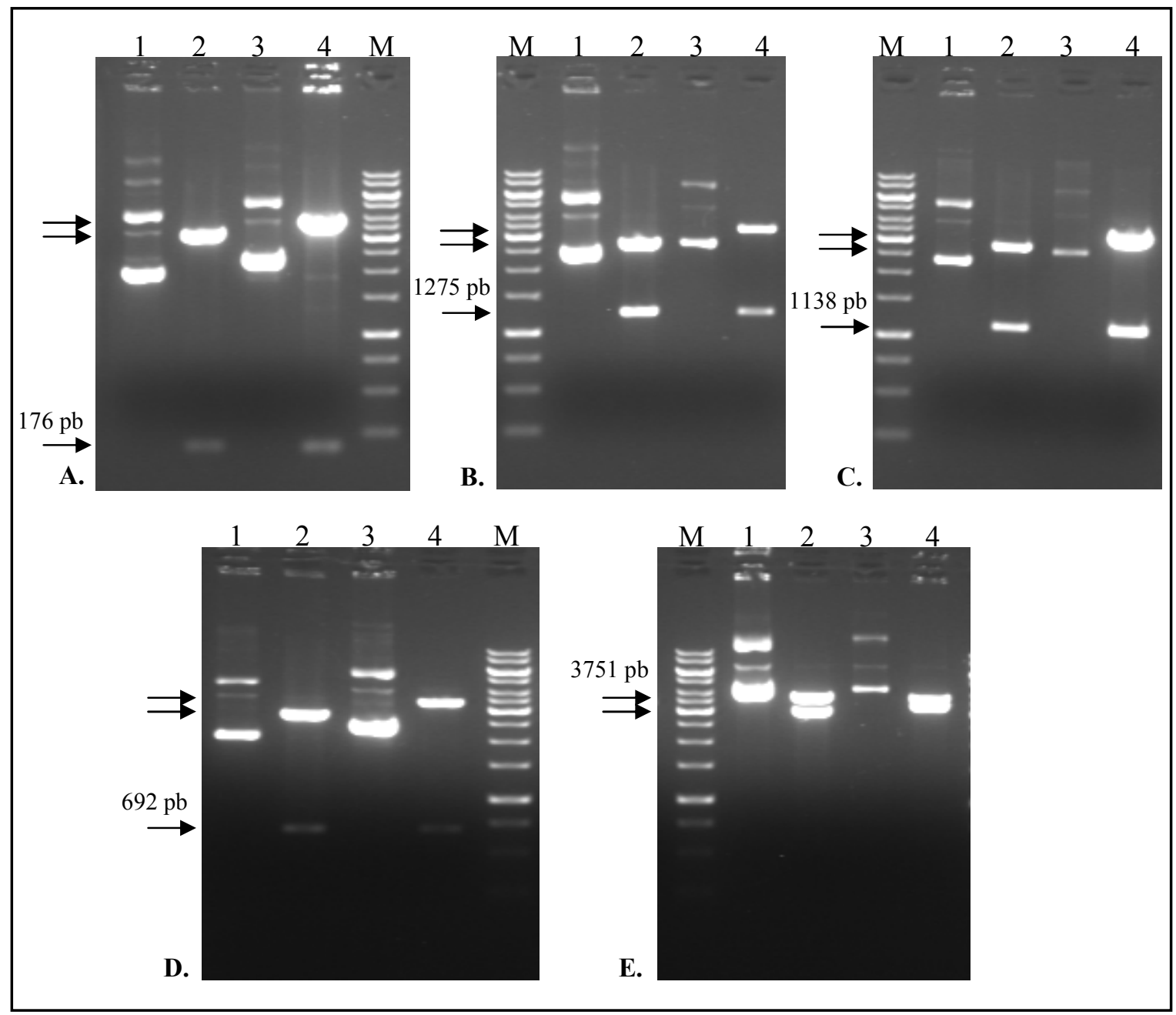

Figura 16 - Análise dos clones plasmidiais por digestão com as enzimas de restrição BamHI e HindIII. Em todos os géis, canaletas: 1- clones em vetor pAE; 2- dupla digestão dos clones em vetor pAE; 3- clones em vetor pAEsox; 4- dupla digestão dos clones em vetor pAEsox. A) LIC10191, B) LIC10793, C) LIC12302, D) LIC11227 e E) LIC13101. Os plasmídeos foram digeridos com as enzimas BamHI e HindIII, exceto os clones com LIC10191 que foram digeridos com a enzima HindIII liberando um fragmento de $176 \mathrm{pb}$. Nas amostras digeridas as bandas de maior massa molecular correspondem aos vetores pAE (2800 pb) e pAEsox (3260 pb) e as bandas de menor massa molecular correspondem aos genes, exceto na figura $\mathrm{E}$, onde a banda de maior massa molecular corresponde ao gene. 


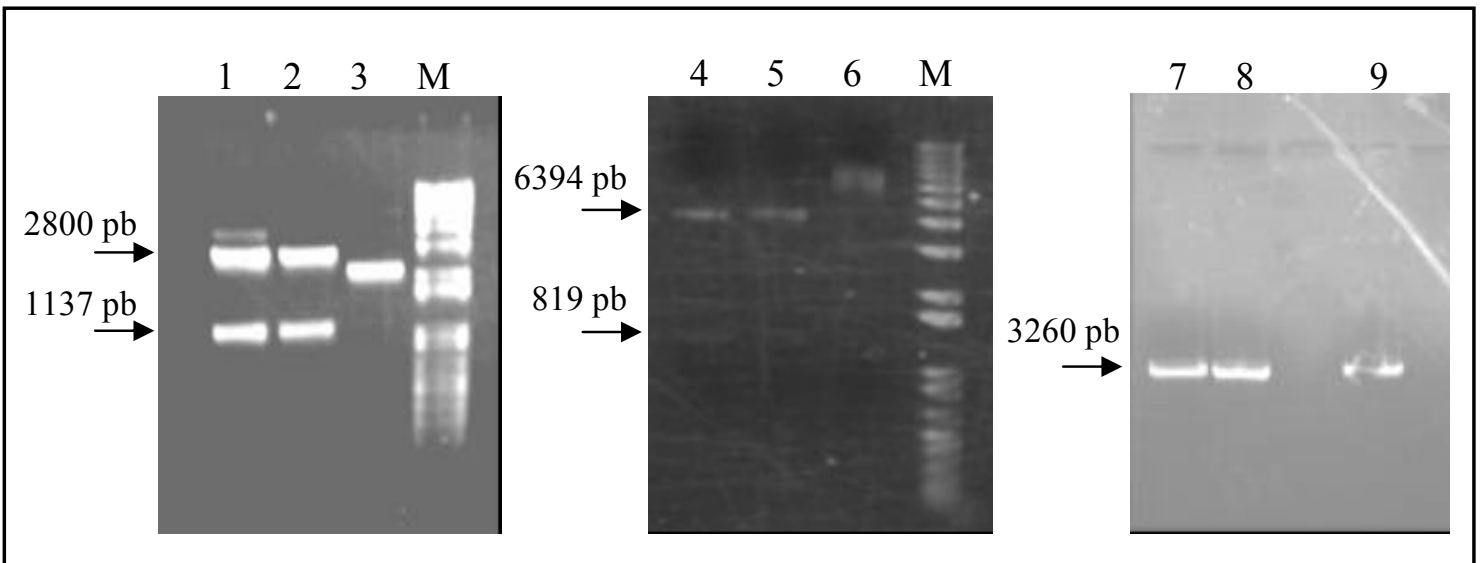

Figura 17 - Análise das digestões dos plasmideos pAELIC10325, pDestLIC11352 e pAEsox com enzimas de restrição, em gel de agarose. Linhas $\mathrm{M}$ - marcador molecular. Canaletas: 1 e 2- digestão do plasmídeo pAELIC10325 com as enzimas NdeI e EcoRI; 3- amostra do vetor pAELIC10325 não digerido, 4 e 5- digestão do vetor pDestLIC11352 com as enzimas NdeI e HindIII, 6- amostra do vetor pDestLIC11352 não digerido, 7 e 8 digestão do vetor pAEsox com as enzimas $N d e I$ e HindIII e 9-digestão do vetor pAEsox com as enzimas NdeI e EcoRI.

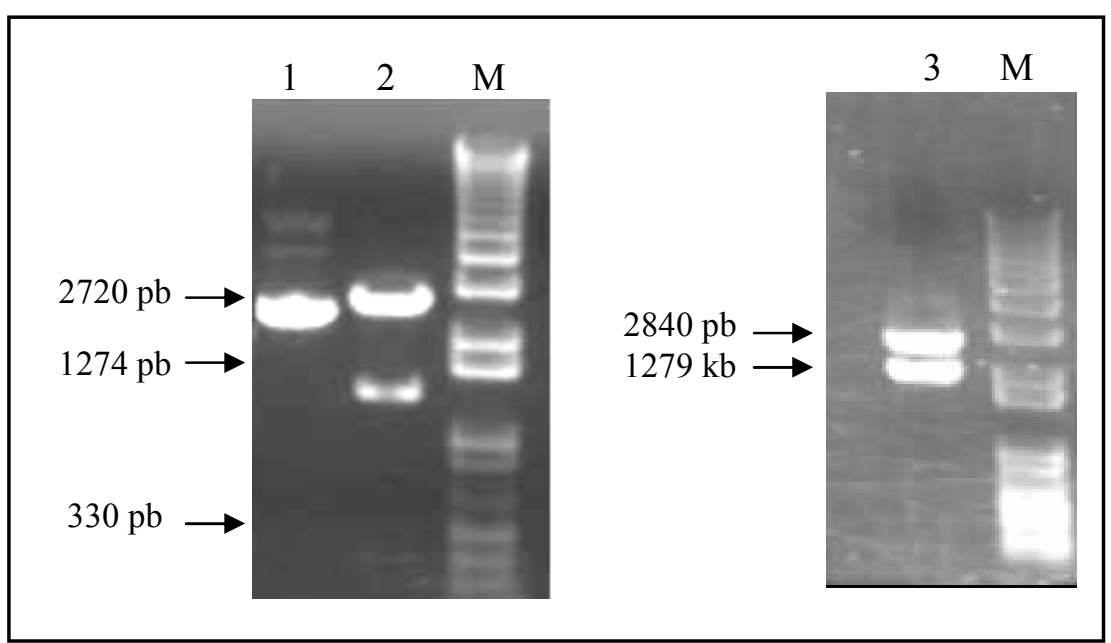

Figura 18 - Análise das construções plasmidiais pAEsoxLIC10325 e pAEsoxLIC11352, por digestão com enzimas de restrição. $M$ - marcador molecular. Canaletas: 1- vetor pAEsox-LIC10325 não digerido, 2- vetor pAEsox-LIC10325 digerido com XbaI e HindIII, 3- vetor pAEsoxLIC11352 digerido com XbaI e HindIII. 


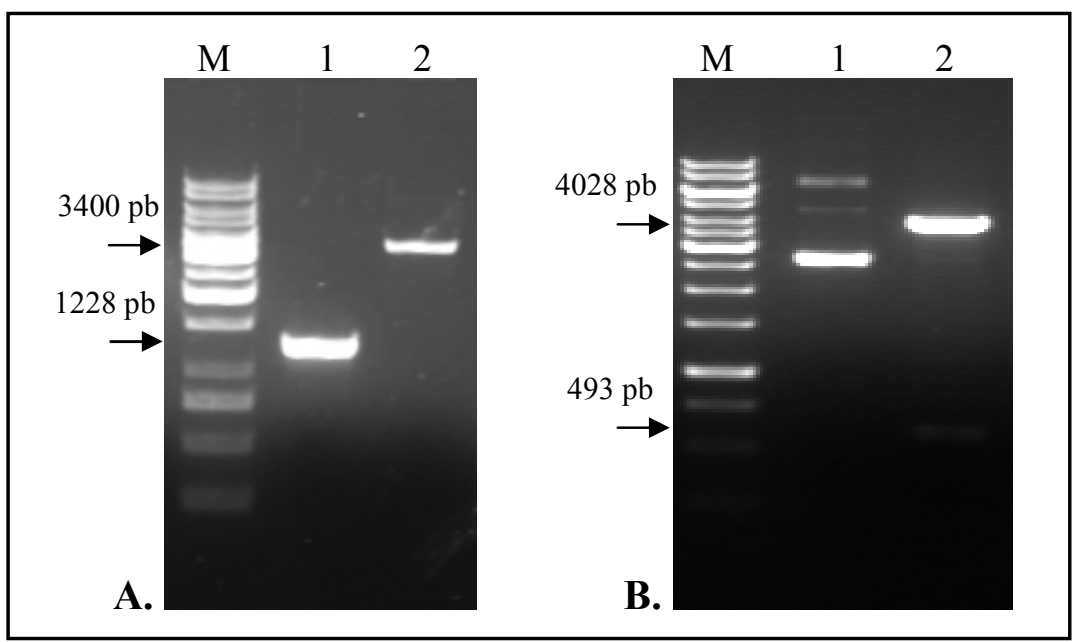

Figura 19 - Análise dos fragmentos de DNA gene LigA, vetor pAEsox digerido e construção plasmidial pAEsoxLigA. $M$ - marcador molecular. A) Canaletas: 1- gene de LigA purificado após digestão de pAELigA com as enzimas XhoI e PstI, 2- vetor pAEsox purificado após digestão com XhoI e PstI; B) Canaletas: 1- miniprep pAEsoxLigA e 2digestão pAEsoxLigA com XbaI e XhoI, liberando dois fragmentos: soxRS (493 pb) e pAELigA (4028 pb).

\subsubsection{Construção de vetores híbridos}

Neste trabalho propusemos a construção de plasmideos híbridos, nos quais os genes de interesse são clonados em tandem com cada gene sob controle de um promotor soxS. Nosso objetivo era melhorar a resposta imune protetora apresentando dois antígenos sem aumentar a dose de salmonela recombinante nas imunizações. Nossa primeira construção utilizou os genes LIC10191 e LIC10793. A construção foi facilitada pela existência de sítios de restrição interessantes para inserção do gene LIC10793 no plasmídeo pAEsoxLIC10191. Elaboramos ainda a construção de mais dois plasmideos hibridos, com os genes LIC10191 e LIC10537, e com os genes LIC10191 e Lip32 em vetor pAEsox.

Para as construções hibridas utilizamos os vetores pAEsox contendo os genes de interesse já clonados. O vetor pAEsoxLIC10191 foi digerido com enzima EcoRI e tratamos com a enzima Klenow Fragment (Fermentas) para formar uma ponta "blunt". O vetor linearizado foi digerido com a enzima $X b a \mathrm{I}$, liberando o fragmento psoxLIC10191 que foi então purificado de um gel de agarose.

Os vetores pAEsoxLIC10793, pAEsoxLIC10537 e pAEsoxLip32 foram digeridos com a enzima NruI para clivar um sítio localizado no final do gene soxR. Os vetores linearizados foram digeridos com a enzima $X b a \mathrm{I}$ e liberaram um fragmento de aproximadamente $300 \mathrm{pb}$ 
com um fragmento do gene soxR. Amostras foram aplicadas em gel de agarose e os vetores pAEsoxLIC10793, pAEsoxLIC10537 e pAEsoxLip32 sem o fragmento do gene soxR foram purificados. O fragmento psoxLIC10191 foi ligado aos vetores. Amostras das reações de ligação foram usadas para transformar bactérias E. coli DH5a. O esquema de construção dos vetores híbridos pAEsoxLIC10191_LIC10793, pAEsoxLIC10191_LIC10537 e pAEsoxLIC10191_Lip32 é apresentado na Figura 20. Fizemos a análise dos clones por ensaios de digestão com enzimas de restrição em gel de agarose (Figura 21). O plasmídeo pAEsoxLIC10191_LIC10793 e pAEsoxLIC10191_LIC10537 foi digerido com a enzima BamHI, liberando um fragmento de 809 pb, que corresponde ao gene LIC10191 (536 pb) mais o promotor sox (273 pb), e um fragmento de $5286 \mathrm{pb}$ ou $4535 \mathrm{pb}$, que correspondem ao vetor pAEsox (3260 pb) mais o gene LIC10537 (2026 pb) ou LIC10793 (1275 pb), respectivamente. O plasmídeo pAEsoxLIC10191_Lip32 foi digerido com a enzima HindIII e como existe um sítio para esta enzima dentro do gene LIC10191 e outro no final do gene Lip32, a digestão liberou um fragmento de 1238 pb que corresponde a 146 pb do gene LIC10191 mais o promotor sox (273 pb) e o gene Lip32 (819 pb). O outro fragmento com $3670 \mathrm{pb}$, que corresponde ao vetor pAEsox (3260 pb) mais 410 pb da porção inicial do gene LIC10191. 


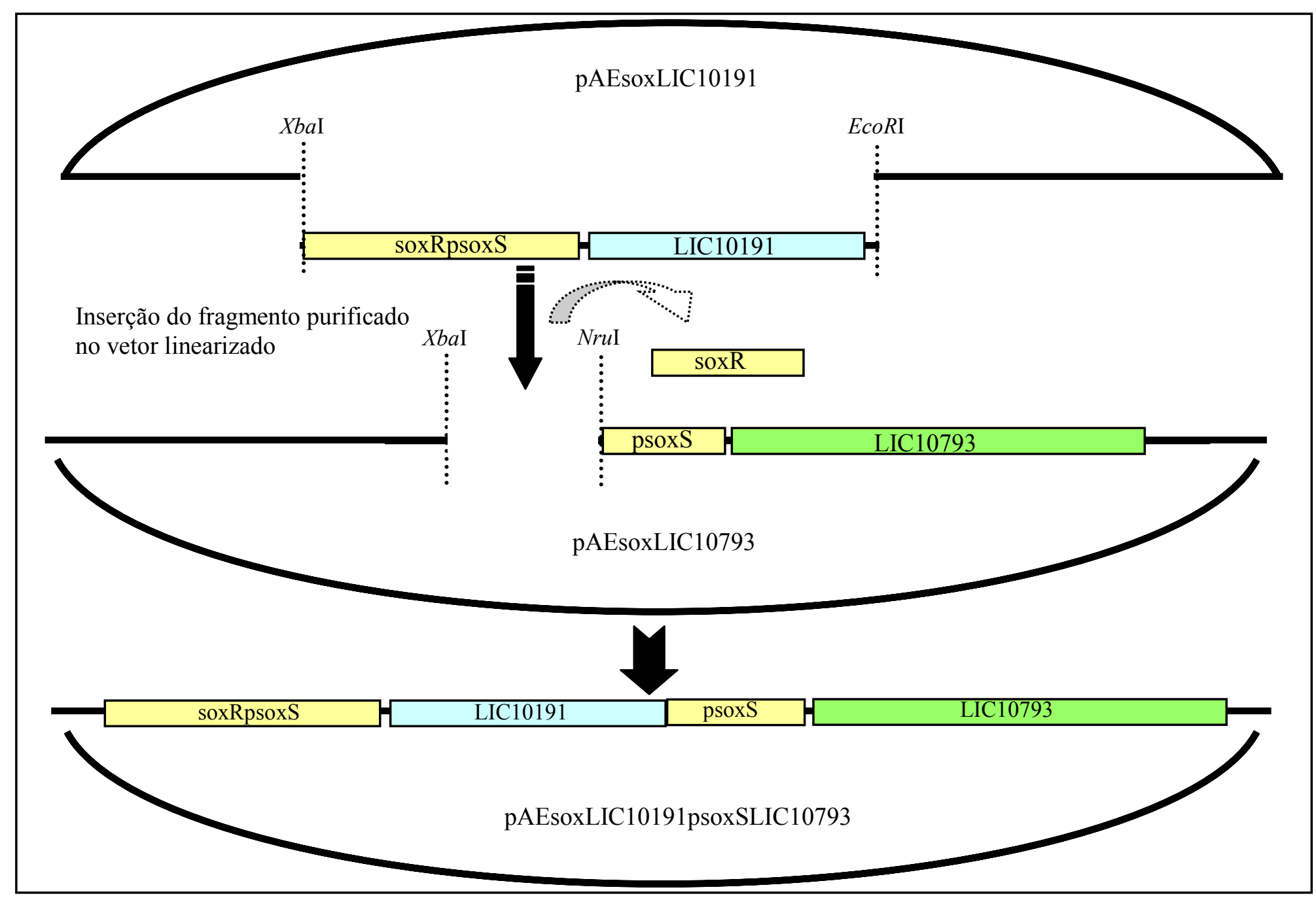

Figura 20 - Esquema da construção do plasmídeo híbrido pAEsoxLIC10191_psoxSLIC10793. Em outras construções o gene LIC10793 foi substituído pelos genes LIC10537 ou Lip32, cada gene com o seu promotor soxS. As linhas pontilhadas indicam os sítios de restrição usados na digestão inicial dos plasmídeos para inserção do gene LIC10191. 


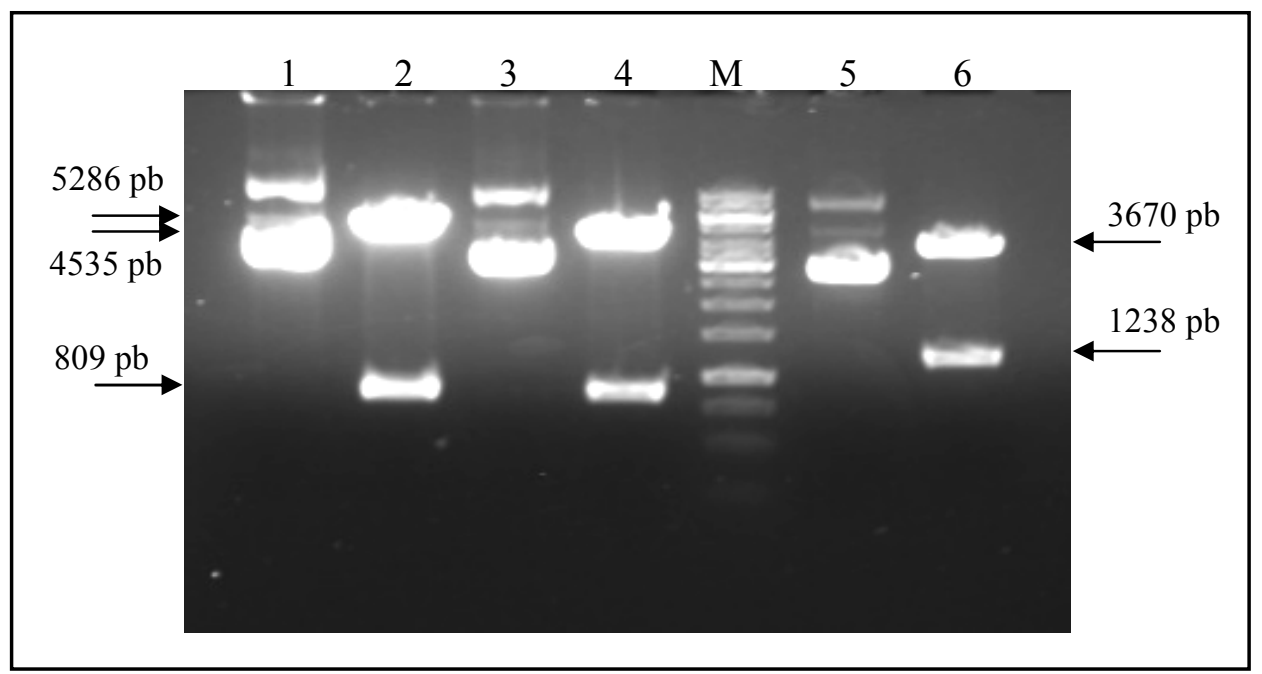

Figura 21 - Análise da construção dos plasmídios híbridos por digestão enzimática. M- marcador de massa molecular. Canaletas: 1- miniprep pAEsoxLIC10191_LIC10537, 2- digestão do plasmídeo pAEsoxLIC10191_LIC10537 com a enzima BamHI, 3- miniprep pAEsoxLIC10191_LIC10793, 4- digestão do plasmídeo pAEsoxLIC10191_LIC10793 com a enzima BamHI, 5- miniprep pAEsoxLIC10191_Lip32, 6- digestão do plasmídeo pAEsoxLIC10191_Lip32 com a enzima HindIII.

\subsection{Expressão das proteínas recombinantes em $E$. coli}

As construções plasmidias, confirmadas por ensaios de digestão com enzimas de restrição e por seqüenciamento foram, utilizadas para transformar bactérias E. coli BL21(DE3)StarpLysS por choque térmico.

\subsubsection{Expressão das proteínas recombinantes isoladas em E. coli}

Para a indução de expressão das proteínas de interesse, culturas de E. coli BL21 com as construções em vetor pAEsox foram expostas a paraquat (PQ) e culturas dos clones com as construções em vetor pAE foram expostas IPTG.

Para confirmar a expressão, amostras dos extratos protéicos foram analisadas por SDS-PAGE (12,5\% poliacrilamida). Nos géis apresentados nas Figuras 22 a 25 podem ser visualizadas bandas de proteínas dos tamanhos previstos, indicando que foram expressas com sucesso in vitro.

As proteínas LIC10191 e LIC10793 foram expressas predominantemente na forma solúvel, sendo possível também observar bandas das proteínas nas frações insolúveis. As proteínas LIC10325 e LIC11352 foram expressas predominantemente na forma insolúvel. As demais proteínas, LIC11227, LIC12302 e LIC13101 foram expressas somente na forma 
insolúvel. A proteína LIC12302 clonada no vetor pAE não foi expressa quando induzida por IPTG. Para as demais proteínas, a expressão nos dois vetores foram semelhantes exceto por um pequeno escape de expressão da LIC10191 no vetor pAE. A expressão em vetor pAE está condicionada ao promotor T7, acessado por RNA polimerase induzível por IPTG. A indução de expressão de proteínas na ausência de indutor não é interessante, pois pode interferir na cinética de crescimento da bactéria, especialmente quando a proteína expressa tem propriedades tóxicas.

Os ensaios de expressão de genes em vetor pAEsox in vitro mais uma vez confirmaram a qualidade do sistema soxRpsoxS para controle de expressão dos genes de interesse. 


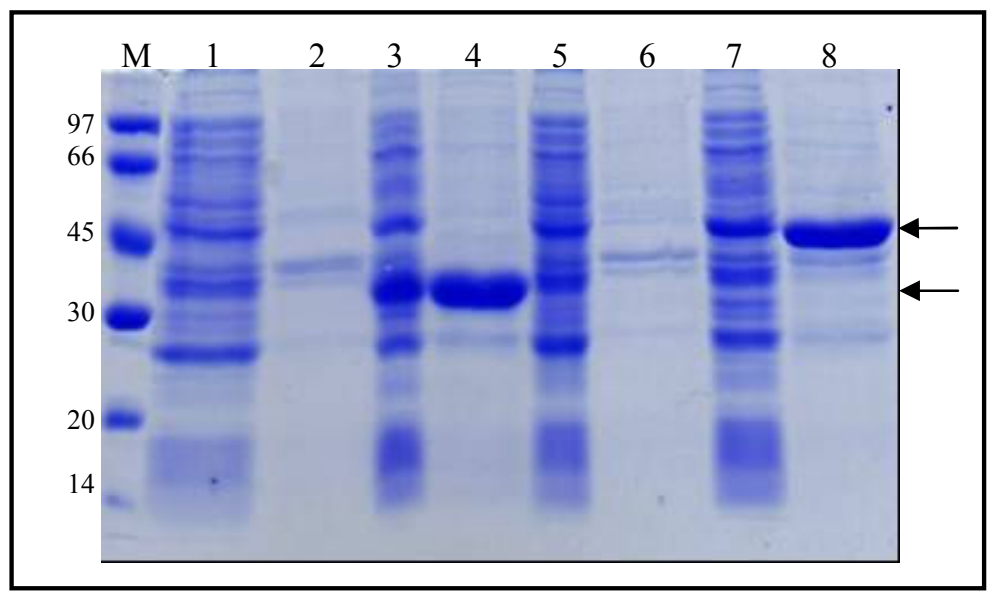

Figura 22 - Análise da expressão das proteínas recombinantes LIC10325 e LIC11352 em vetor pAEsox em $\boldsymbol{E}$. coli BL21. SDS - PAGE comparando o padrão de bandas de proteínas nas frações de precipitado e sobrenadante dos extratos celulares após a indução de expressão. M- marcador de massa molecular. Canaletas: 1 a 4- LIC11352 (30,7 kDa), 5 a 8- LIC10325 (42,3 kDa). Canaletas impares - frações solúveis, canaletas paresfrações insolúveis; canaletas: 1,2, 5, 6- controles (não induzido); 3, 4, 7, 8- cultivos induzidos com PQ.

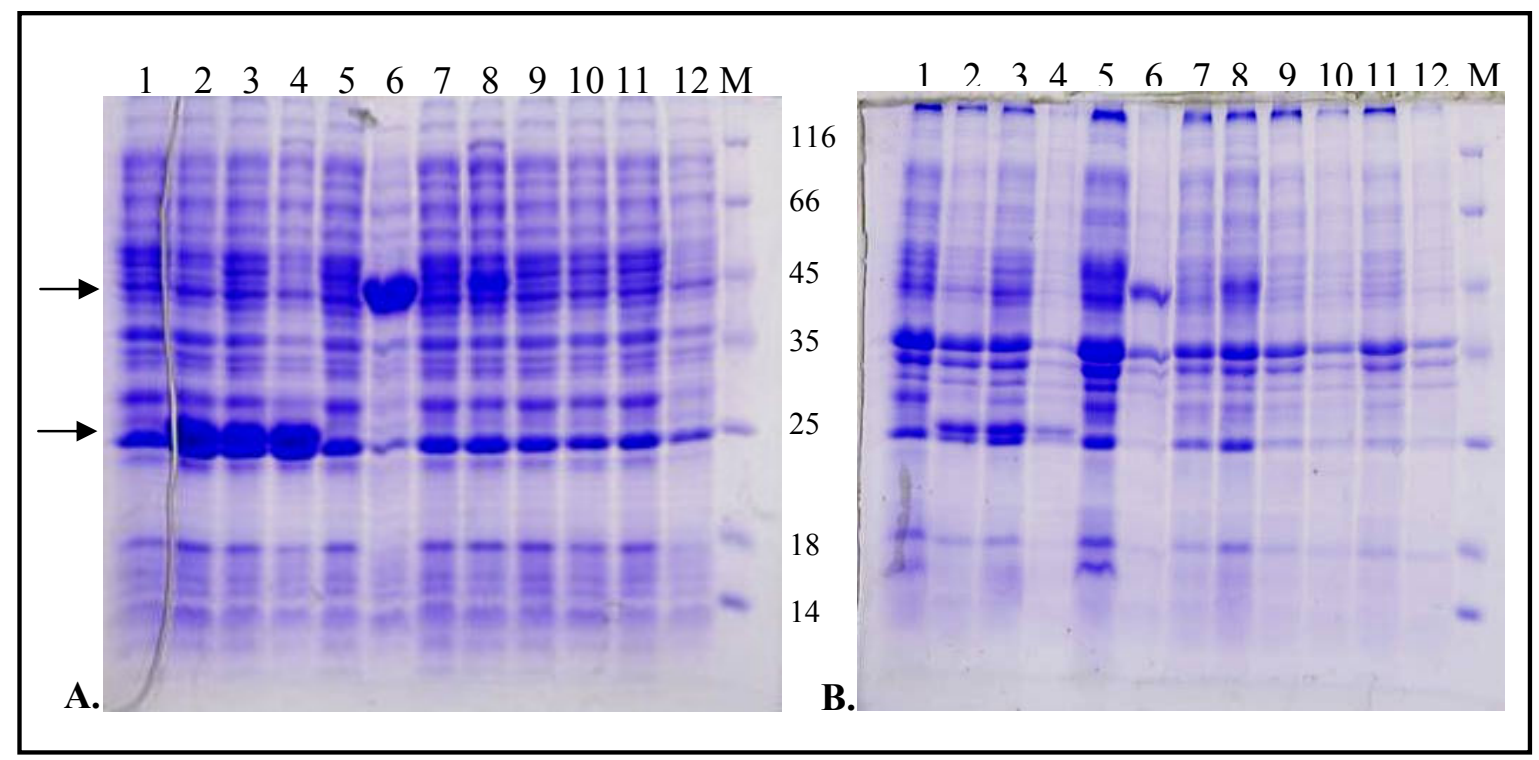

Figura 23 - Análise da expressão das proteínas recombinantes LIC10191 e LIC10793 em E. coli B121. SDS PAGE em A) amostras das frações solúveis e em B) insolúveis. Canaletas ímpares- controle (não induzidas) e canaletas pares- amostras de culturas induzidas por paraquat (pAEsox) ou IPTG (pAE). Canaletas: 1 e 2- pAEsoxLIC10191 (20,3 kDa), 3 e 4pAELIC10191, 5 e 6- pAEsoxLIC10793 (49,3 kDa), 7 e 8- pAELIC10793, 9 e 10pAEsox sem inserto, 11 e 12- pAE sem inserto. 


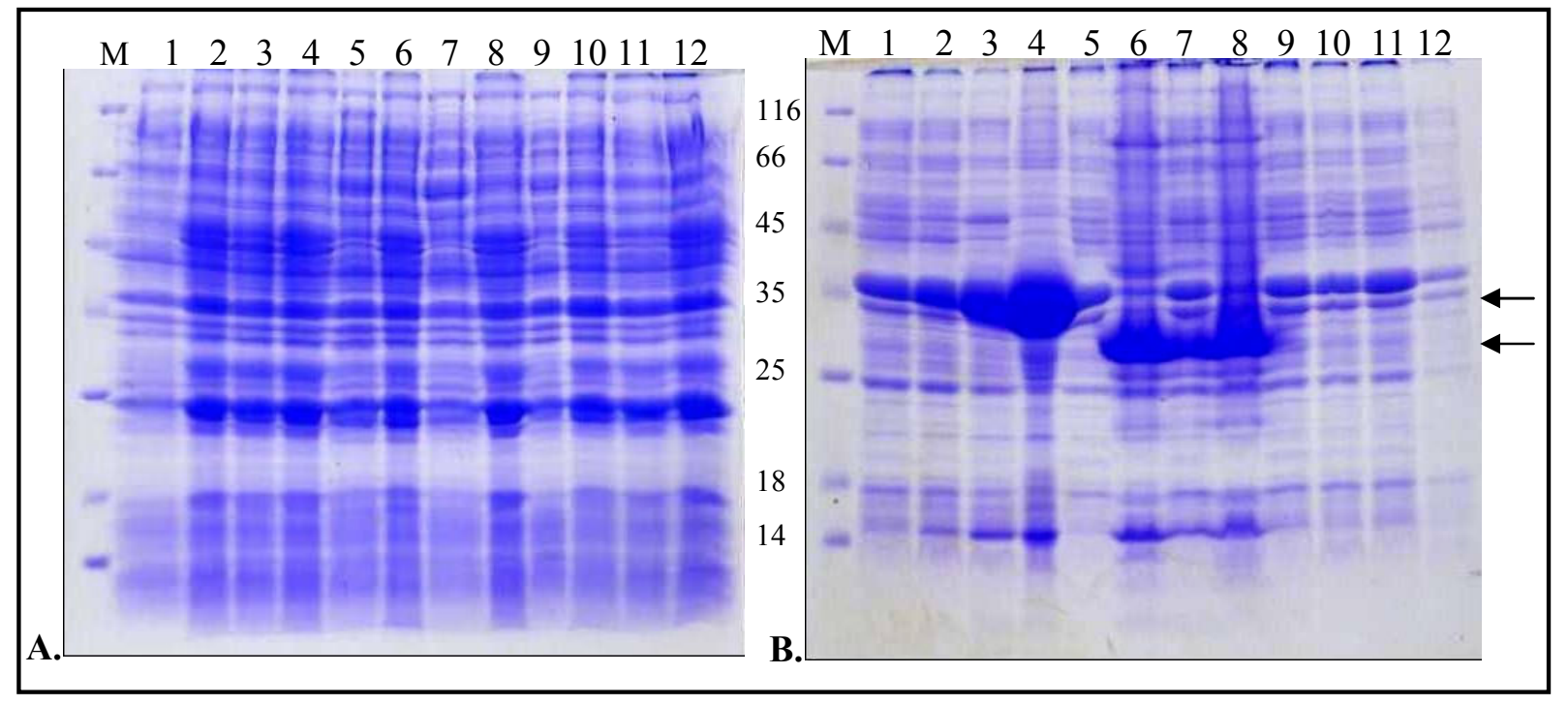

Figura 24 - Análise da expressão das proteínas recombinantes LIC12302 e LIC11227 em E. coli B121. SDS PAGE em A) amostras das frações solúveis e em B) frações insolúveis. Mmarcador de massa molecular. Canaletas ímpares- controle (não induzidas) e canaletas pares- cultivos induzidos por paraquat (vetor pAEsox) ou IPTG (vetor pAE). Canaletas: 1 e 2- pAELIC12302 (38,9 kDa), 3 e 4- pAEsoxLIC12302, 5 e 6- pAELIC11227 (28,5 kDa), 7 e 8-pAEsoxLIC11227, 9 e 10- pAE sem inserto, 11 e 12-pAEsox sem inserto.

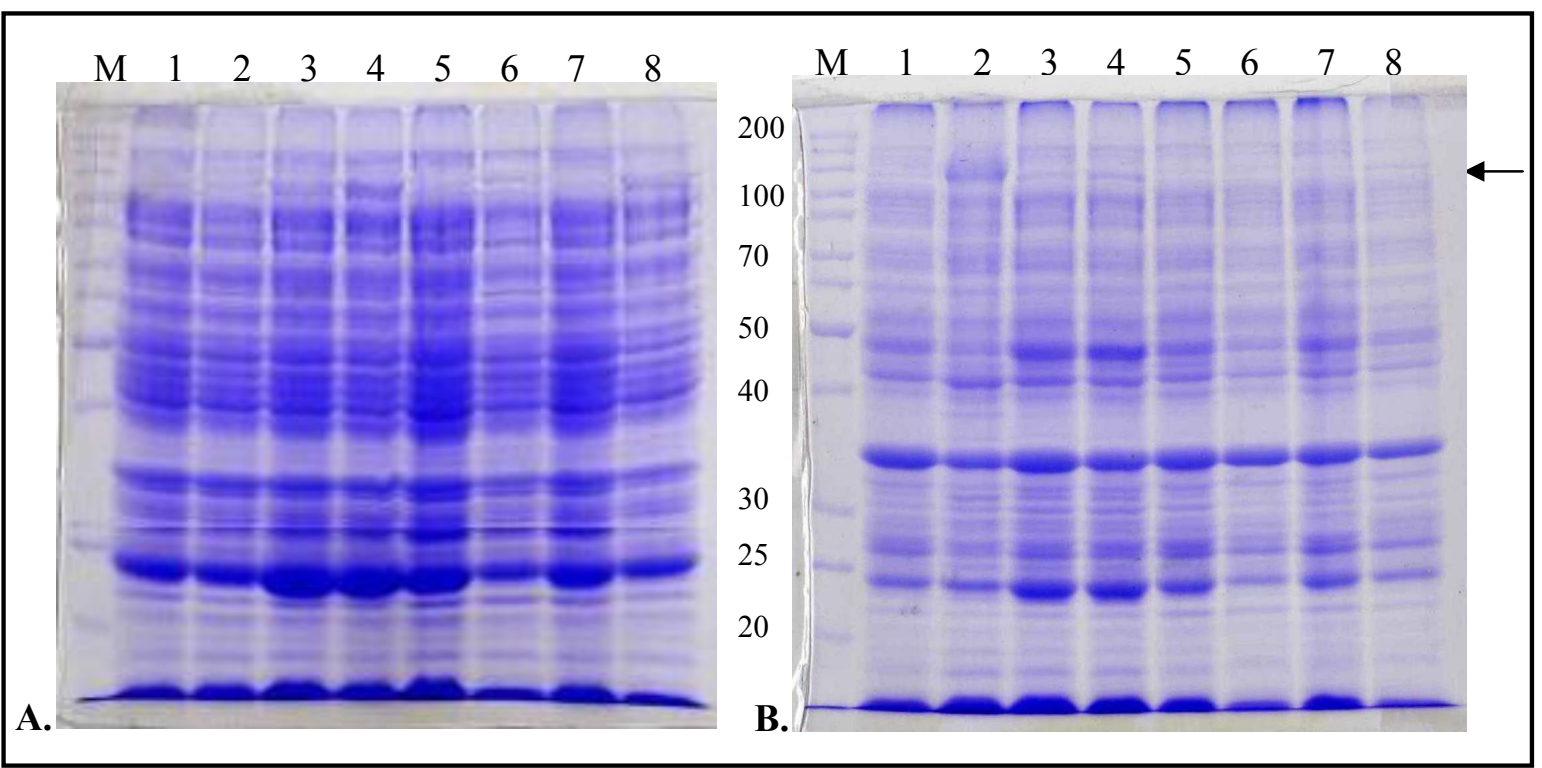

Figura 25 - Análise da expressão da proteína LIC13101 recombinante em $E$. coli BI21. SDS PAGE em A) amostras das frações solúveis e em B) frações insolúveis. M- marcador de massa molecular. Canaletas ímpares- amostras de cultivos não induzidos e canaletas pares- cultivos induzidos por paraquat (pAEsox) ou IPTG (pAE). Canaletas: 1 e 2pAEsoxLIC13101 (127 kDa), 3 e 4- pAELIC13101, 5 e 6- pAEsox sem inserto; 7 e 8pAE sem inserto. 


\subsubsection{Expressão das proteínas nos clones de E. coli com os vetores híbridos}

Após a confirmação da construção dos vetores híbridos por ensaios de digestão e por seqüenciamento, os plasmídeos foram usados na transformação de bactérias E. coli BL21(DE3)StarpLysS. Em duas das três construções a expressão simultânea das proteínas foi testada pó adição de PQ ao meio de cultivo. Amostras dos extratos bacterianos separados em fração solúvel e insolúvel foram analisadas por SDS-PAGE. As proteínas LIC10191 e LIC10793 apresentaram as mesmas características uando expressas isoladamente, predominantemente na fração solúvel (Figura 26A). Podemos observar que há maior expressão da proteína LIC10793 em relação a proteína LIC10191. Na figura 26B podemos visualizar que houve expressão das proteínas LIC10191 e LIC10537 simultaneamente. Neste caso, a proteína LIC10191 foi mais expressa em comparação com a LIC10537. A LIC10537 possui alto massa molecular, $76 \mathrm{kDa}$, e foi expressa na forma insolúvel.

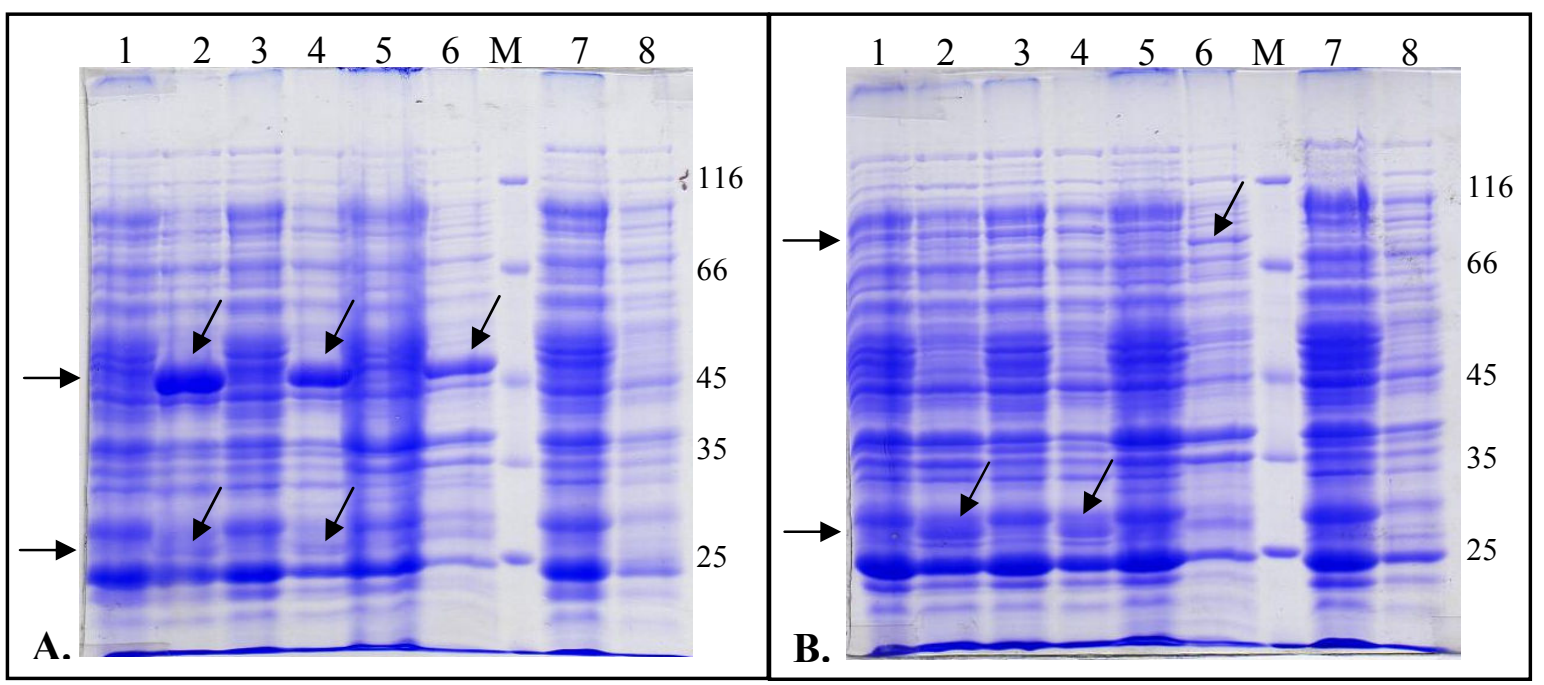

Figura 26 - Análise da expressão em E.coli das proteínas recombinantes nos clones com vetores híbridos LIC10191_LIC10793 e LIC10191_LIC10537. M- marcador molecular. Canaletas ímpares- amostras de extratos bacterianos de cultivo não induzidas e canaletas pares- amostras de culturas induzidas por paraquat. A) Canaletas: 1 a 6- pAEsoxLIC10191_LIC10793; 1 e 2 extrato total, 3 e 4- fração solúvel, 5 e 6- fração insolúvel, 7 e 8- clone com pAEsox sem inserto. B) Canaletas: 1 a 6- híbrido pAEsoxLIC10191_LIC10537, 1 e 2- extrato total, 3 e 4- fração solúvel, 5 e 6- fração insolúvel, 7 e 8-pAEsox sem inserto.

Os testes de expressão in vitro de bactérias $E$. coli pela indução do promotor sox foram realizados com sucesso. A adição de paraquat a cultura de bactérias transformadas com vetor pAEsox se mostrou um método funcional para a análise das expressãoes das proteínas recombinantes in vitro. Com essa confirmação, partimos para a transferência das construções em pAEsox para as salmonelas. 


\subsection{Clonagem e expressão de proteínas em salmonela}

O protocolo de transformação das salmonelas competentes foi também transformação química como em E. coli. Neste caso, além da ampicilina, as culturas foram crescidas em meio 2YT com novobiocina, antibiótico que permite o crescimento da salmonela. Antes da transformação da linhagem vacinal SL3261 foi necessária a transformação da salmonela SL4213, linhagem intermediária com genótipo deficiente no sistema de restrição e de reconhecimento de DNA exógeno. O DNA extraído da linhagem SL4213 pode ser usado na transformação da linhagem vacinal.

\subsubsection{Expressão das proteínas isoladas em salmonela}

As proteínas LIC10191, LIC10793, LIC11227 e LIC10325 foram expressas em salmonela com sucesso (Figuras 27 e 28). Em nossos ensaios encontramos algumas dificuldades na análise de expressão de algumas das proteínas estudadas, sendo que não foi possível visualizar as bandas de expressão das proteínas LIC13101 e LIC12302. Nos extratos de salmonelas observa-se certo arraste na separação das proteínas por SDS-PAGE, dificultando a visualização, em especial das proteínas de alta massa molecular, como a LIC13101 (127 kDa). A proteína LIC13101 é formada por dois domínios de repetição interna e sete domínios similares a da alfa integrina. Os domínios integrina tem sido associados a adesão celular e por isso a proteína pode ter papel importante em virulência. Uma estratégia para investigação dessa proteína seria clivar o gene para expressar fragmentos e testar a imunogenicidade dos domínios. Para a maioria das proteínas não houve diferença de expressão nas duas bactérias, sendo pequenas diferenças atribuídas ao tempo de cultivo ou de indução.

Transferimos o plasmídeo pAEsoxLigA para a salmonela SL3261 e fizemos um teste de expressão in vitro. O fragmento terminal da proteína LigA é expresso na forma insolúvel em E. coli (SILVA et al., 2007). Como não conseguimos distinguir a banda da proteína por SDS-PAGE, realizamos ensaios de western blot, usando soro de camundongos imunizados com a proteína purificada cedido por Vivian Hashimoto. Podemos observar que a proteína foi reconhecida pelo soro na fração solúvel do lisado da cultura de salmonela, confirmando a expressão da proteína pelo clone (Figura 29). 


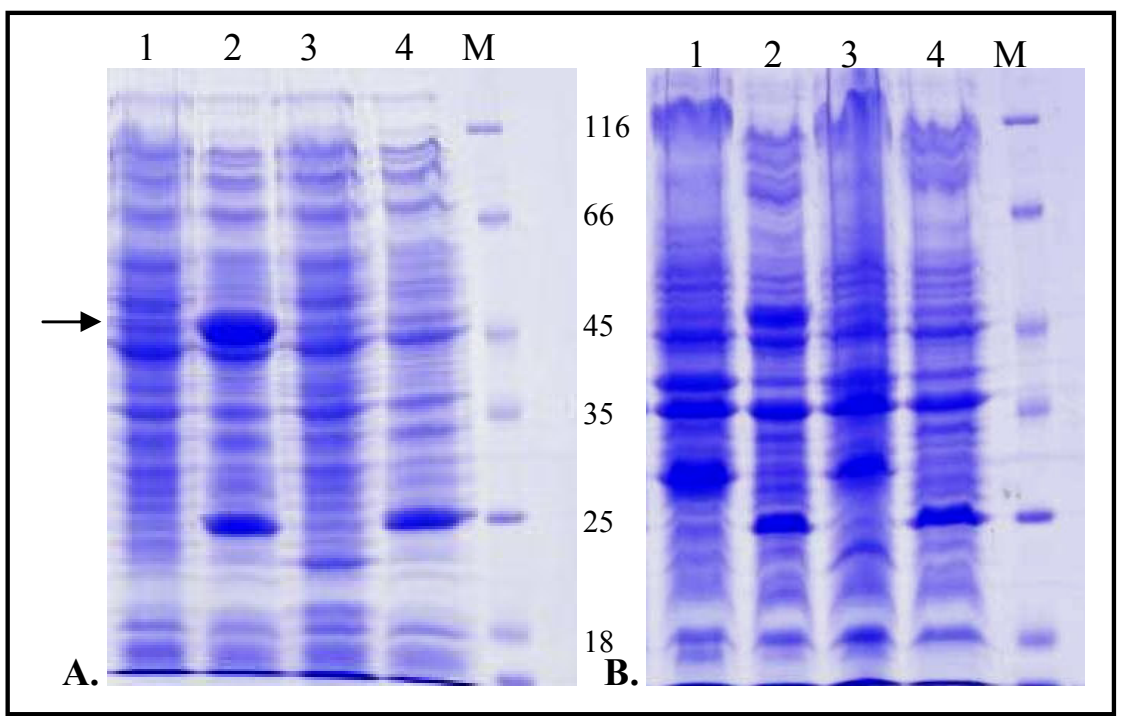

Figura 27 - Análise da expressão da proteína recombinante LIC10793 em salmonela SL3261 in vitro. SDS PAGE em A) - amostras das frações solúveis e em B) frações insolúveis dos extratos bacterianos. Canaletas ímpares - amostras de culturas não induzidas e canaletas pares - culturas induzidas por paraquat. Canaletas: 1 e 2- pAEsox-LIC10793, 3 e 4pAEsox sem inserto.

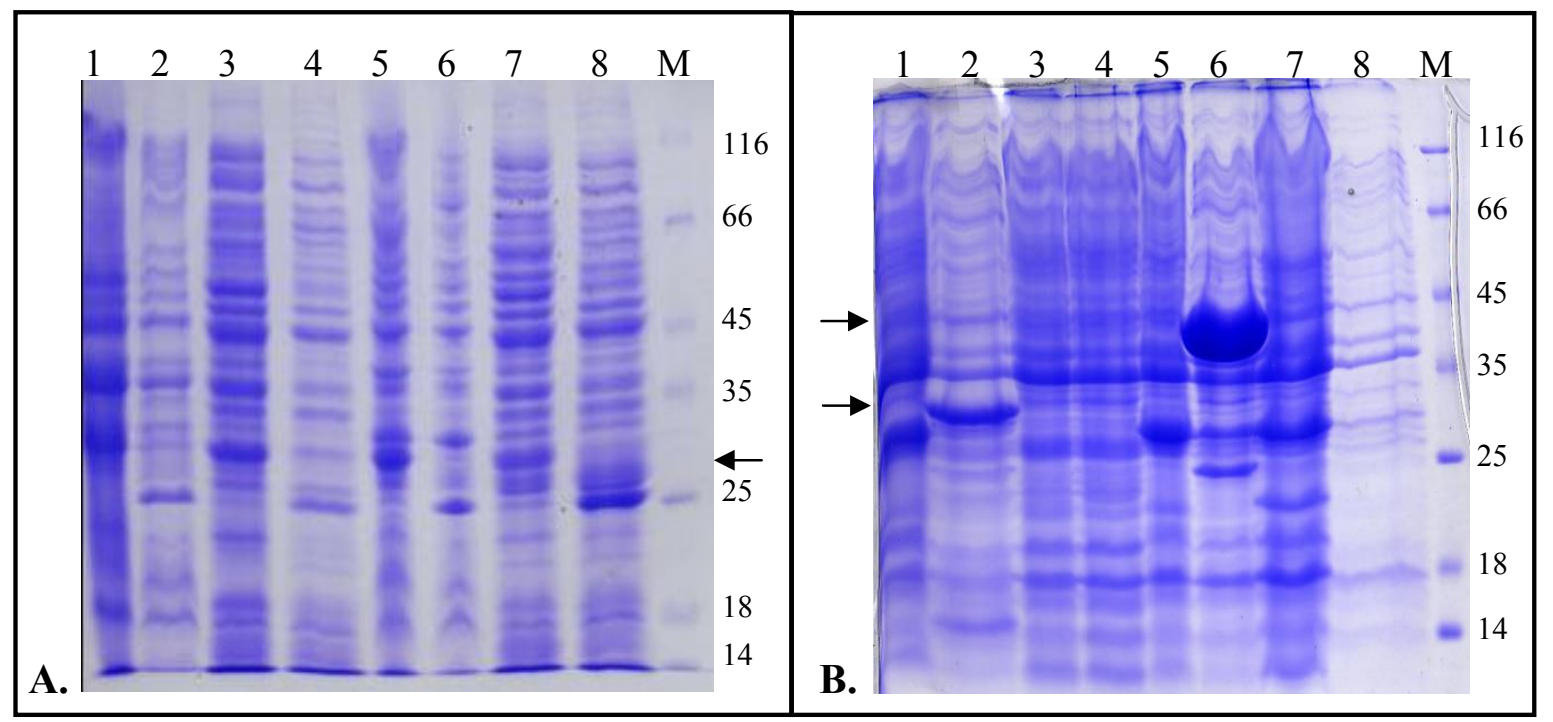

Figura 28 - Análise da expressão da proteína LIC10191, LIC11227, LIC13101 e LIC10325 em salmonela SL3261 in vitro por SDS PAGE. Canaletas ímpares com amostras de culturas não induzidas e nas pares amostras de culturas induzidas. A) Canaletas: 1 e 2- pAEsox sem inserto fração insolúvel; 3 e 4- pAEsox sem inserto fração solúvel, 5 e 6pAEsoxLIC10191 fração insolúvel; 7 e 8- pAEsoxLIC10191 fração solúvel. B) amostras de fração insolúvel. Canaletas: 1 e 2-pAEsox-LIC11227, 3 e 4- pAEsox-LIC13101, 5 e 6pAEsox-LIC10325, 7 e 8- pAEsox sem inserto. 


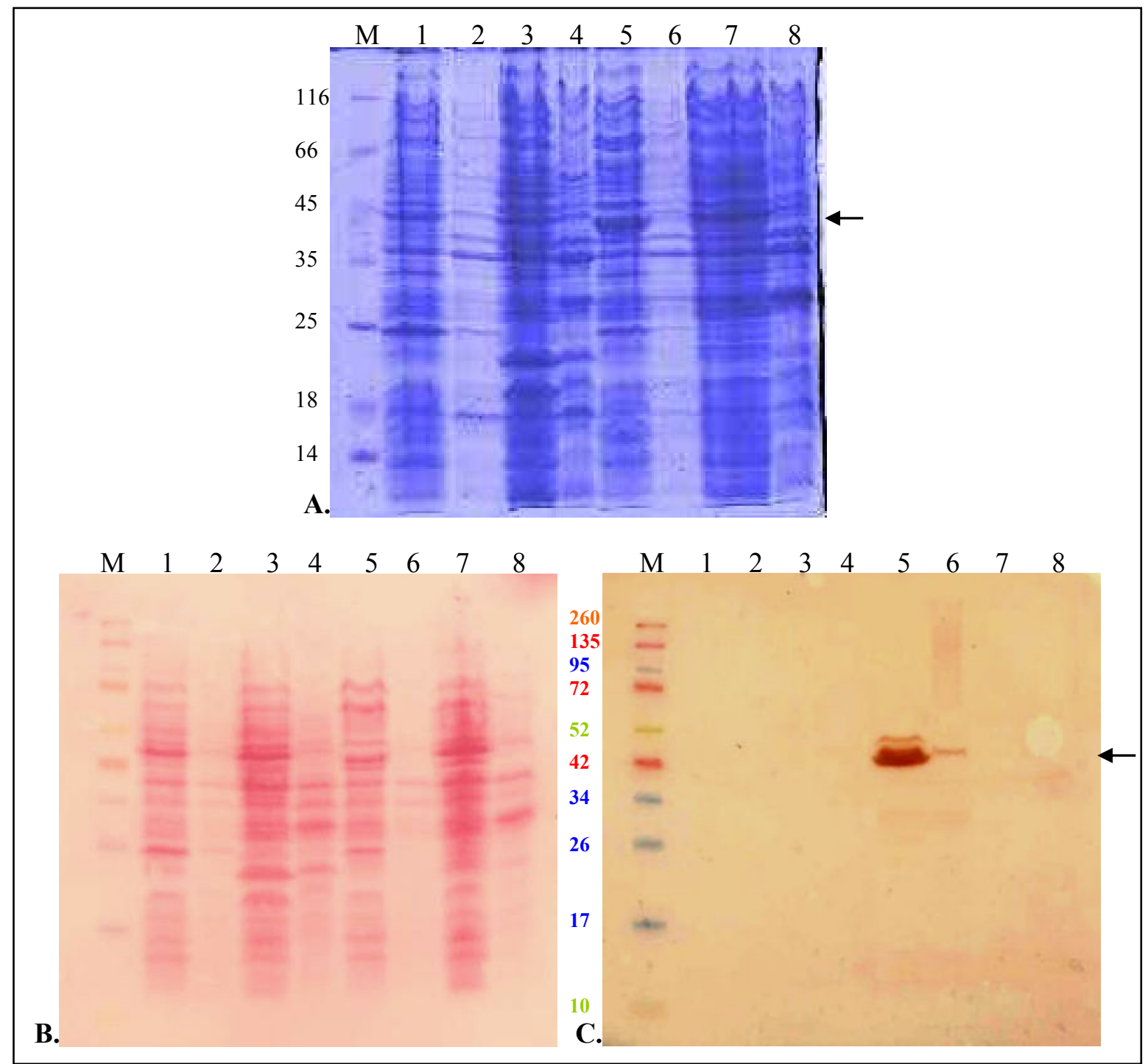

Figura 29 - Análise da expressão da proteína recombinante LigA em salmonela SL3261pAEsoxLigA, por western blot. M- marcador de massa molecular. A) SDS PAGE corado com comassie; B) membrana corada com ponceau após a transferência das proteínas separadas por SDS PAGE; C) membrana revelada após a incubação com soro de camundongos imunizados com a proteína LigA. Mmarcador de massa molecular. Canaletas impares fração solúvel e pares fração insolúvel. Canaletas: 1 e 2- SL3261 exposta a PQ, 3 e 4- SL3261 não exposta a PQ, 5 e 6 - SL3261 LigA induzidas e 7 e 8- SL3261 LigA não induzida. 


\subsubsection{Expressão das proteínas nos clones de salmonela com os vetores híbridos}

Os clones de E. coli com plasmídeos híbridos expressaram as proteínas com sucesso e, então os plasmídeos, foram usados para transformar salmonela SL4213 e, a partir dos DNAs plasmidiais obtidos desta bactéria, transformar a linhagem vacinal SL3261 para os ensaios de imunização. Os clones de SL3261 com os vetores híbridos foram induzidos a expressar as proteinas recombinantes por exposição ao paraquat (Figuras 30 a 32).

Clones de salmonela com plasmideo híbrido pAEsoxLIC10191_LIC10793, mostraram a expressão das duas proteínas in vitro, quando cultivado em presença de PQ (Figura 30A). As duas proteínas foram expressas na forma solúvel, como quando induzidas isoladamente. Para confirmação da expressão das proteínas fizemos um western blot utilizando anticorpo monoclonal anti-6xHis contra extrato solúvel de SLLIC10191_LIC10793 induzida por PQ e utilizamos SLLIC10191, SLLIC10793, as proteínas LIC10191 e LIC10793 como controles positivos e o extrato solúvel de SL vazia também induzida como controle negativo (Figura $31)$.

A salmonela com plasmideo pAEsoxLIC10191_LIC10537 mostrou, em SDS PAGE 10\%, apenas a expressão da LIC10191 in vitro, quando o clone foi cultivado em presença de PQ. As proteínas de alta massa molecular não são bem separadas por SDS-PAGE 10\%, como observado anteriormente (Figura 30B).

O plasmídeo híbrido pAEsoxLIC10191_Lip32 também foi utilizado para transformar salmonela SL3261. Nos ensaios de expressão in vitro não conseguimos diferenciar as bandas das proteínas LIC10191 e Lip32 (figura 32A). Realizamos, então, ensaios western blot usando soros de animais imunizados com cada uma dessas proteínas purificadas. Alguns clones foram testados e os extratos protéicos aplicados em SDS-PAGE 12,5\%. As proteínas foram transferidas de géis para membranas e estas foram expostas aos soros de camundongos imunizados com a proteína purificada LIC10191 ou a proteína Lip32 (Figuras 32B e 32C). As proteínas recombinantes nos extratos de salmonela foram reconhecidas pelos soros, confirmando a expressão in vitro. A pequena diferença no peso molecular entre as proteínas recombinantes purificadas e as expressas pela salmonela se deu pela retirada da cauda de histidina na construção do vetor híbrido. Os clones foram guardados em freezer $-80{ }^{\circ} \mathrm{C}$ para o ensaio de imunização. 


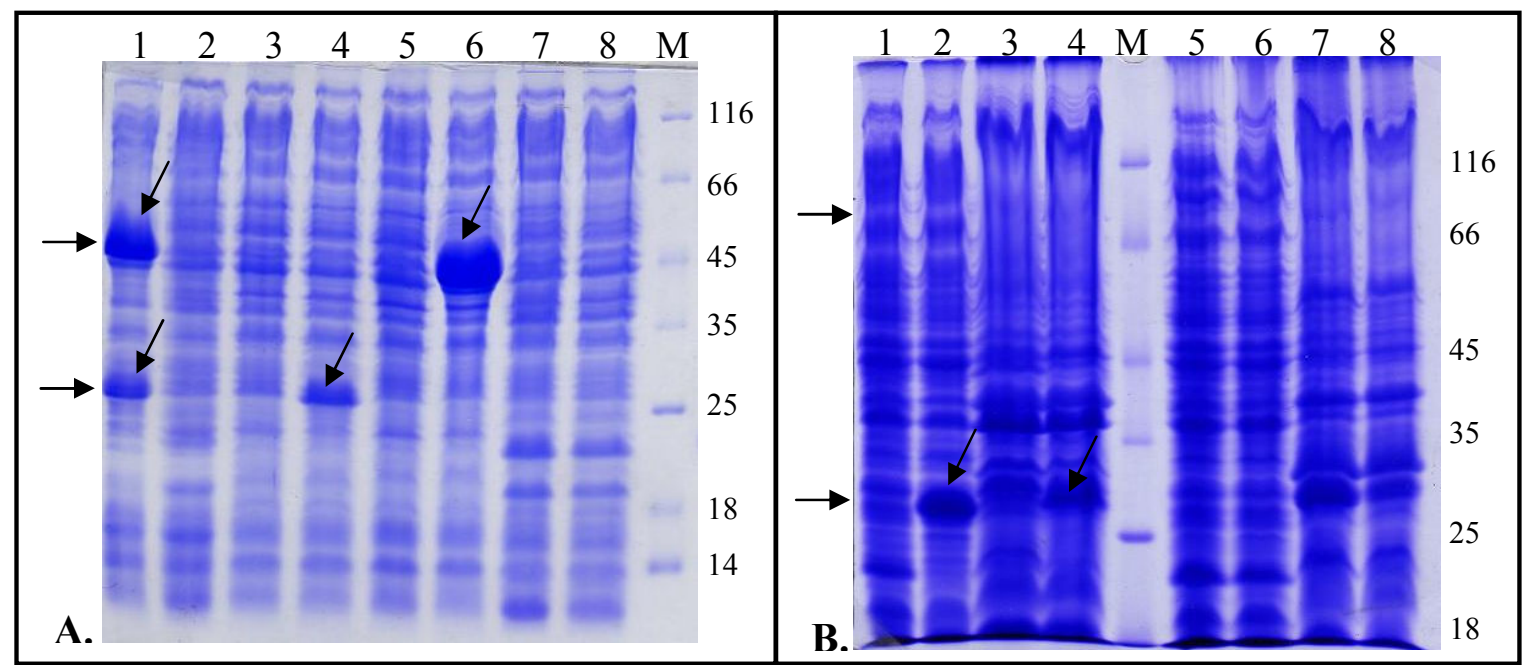

Figura 30 - Análise da expressão das proteínas recombinantes em salmonelas com vetores híbridos pAEsoxLIC10191_LIC10793 e pAEsoxLIC10191_LIC10537. M- marcador molecular. A) frações solúveis dos extratos de salmonela. Canaletas: 1 e 2- híbrido pAEsoxLIC10191_LIC10793, 1-induzido e 2- controle; 3 e 4- pAEsoxLIC10191, 3controle e 4- induzido; 5 e 6- pAEsoxLIC10793, 5- controle e 6- induzido; 7 e 8 pAEsox sem inserto, 7- controle e 8- induzido. B) Canaletas ímpares culturas bacterianas não induzidas e pares induzidas por PQ. Canaletas: 1 a 4- híbrido pAEsoxLIC10191_LIC10537 em salmonela, 1 e 2 fração solúvel, 3 e 4- fração insolúvel, 5 a 8-pAEsox sem inserto, 5 e 6 fração solúvel, 7 e 8 - fração insolúvel.

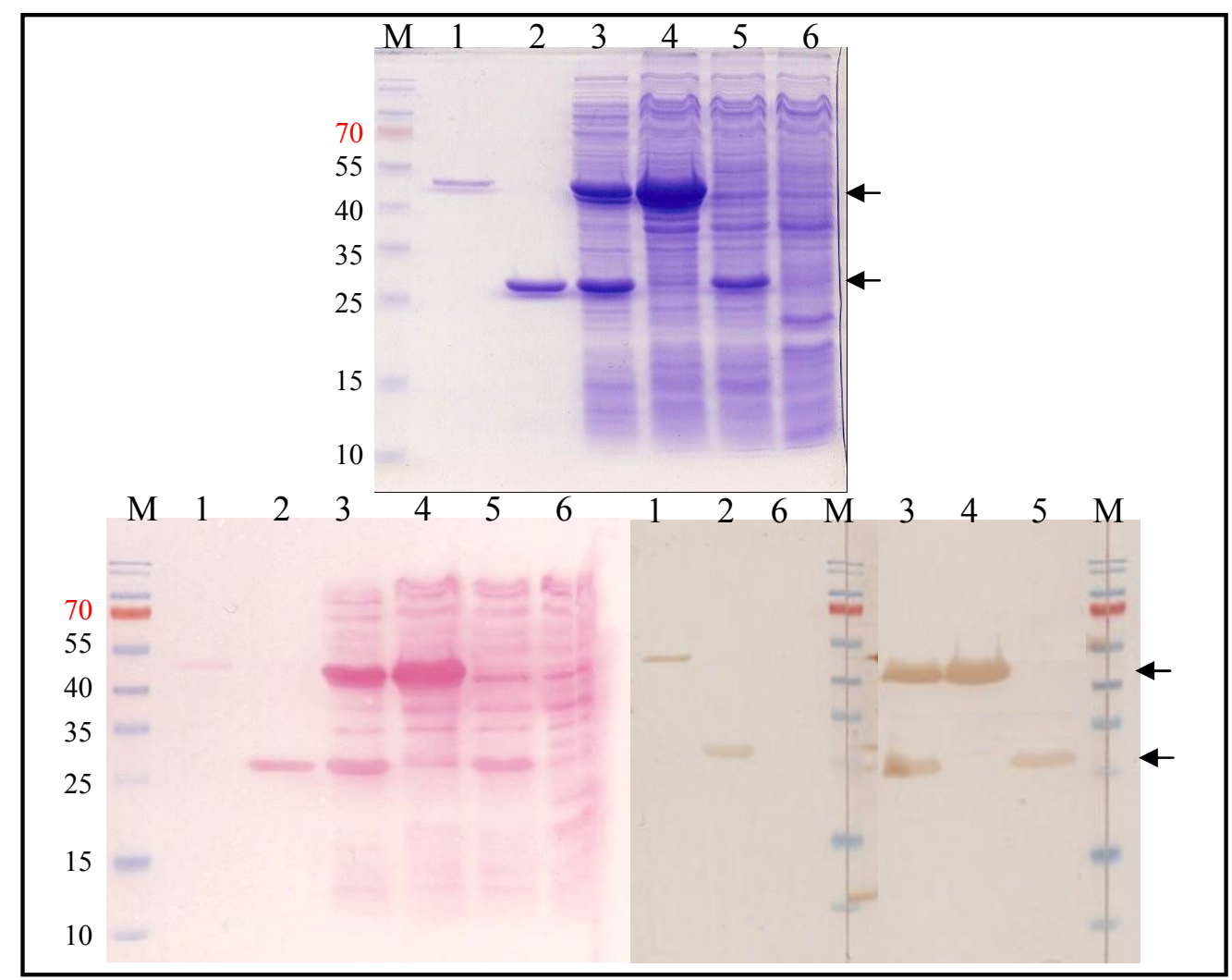

Figura 31 - Análise da expressão das proteínas LIC10191 e LIC10793 nos extratos solúveis de salmonela. M- marcador de massa molecular. Canaletas: 1- proteína LIC10793, 2proteína LIC10191, 3 a 6 extratos 3- SLLIC10191_LIC10793, 4- SLLIC10793, 5SLLIC10191 e 6- SL vazia. A) SDS PAGE corado com comassie, B) membrana corada com Ponceau e C) membrana incubada com anticorpo anti-6xHis (diluição 1:10000). 


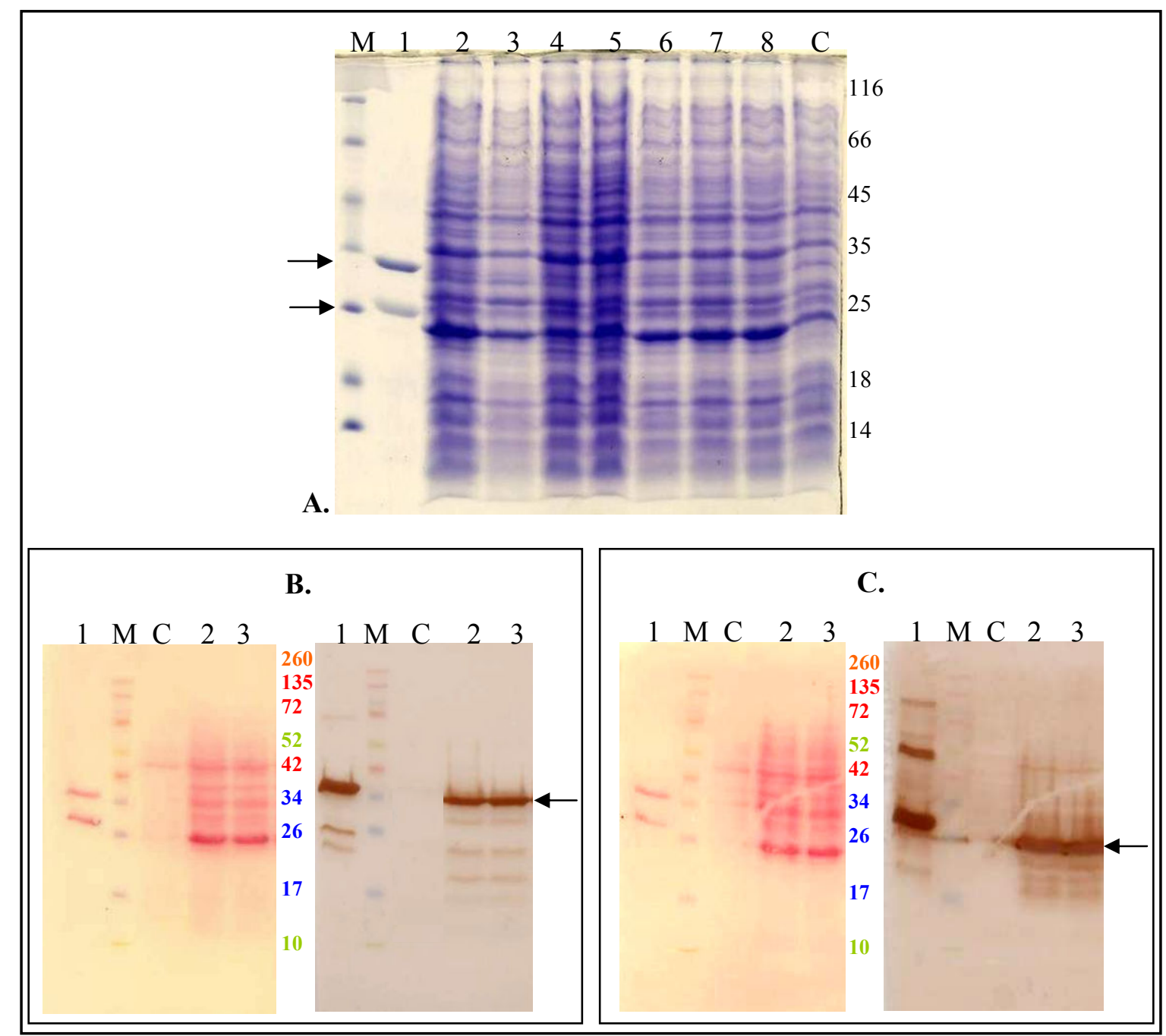

Figura 32 - Análise da expressão das proteínas recombinantes LIC10191 e LIC11352 (Lip32) em salmonela SL3261 por western blot. A) SDS PAGE com amostras de extrato total de proteínas, fração solúvel e insolúvel, de diferentes clones de salmonela carregando plasmídeo híbrido induzidos. B) membrana corada com ponceau e revelada após a incubação com soro de camundongos imunizados com a proteína Lip32. C) membrana corada com ponceau e revelada após a incubação com soro de camundongos imunizados com a proteína LIC10191. M- marcador de massa molecular. C- controle salmonela vazia; canaletas: 1- proteínas LIC10191 e Lip32 purificadas, 2 a 8-amostras dos diferentes clones induzidos. 


\subsection{Purificação das proteínas recombinantes}

As proteínas recombinantes foram expressas em clones de E. coli B121(DE3) StarpLysS e purificadas por IMAC.

As proteínas LIC10191 e LIC10793 foram expressas na forma solúvel e foram purificadas a partir dos sobrenadantes dos extratos bacterianos. A eluição das proteínas foi feita com solução de eluição (tampão Tris $\mathrm{HCl} 20$ mM pH 8,0, $\mathrm{NaCl} 150$ mM) com diferentes concentrações de imidazol. A proteína LIC10191 foi eluida com $150 \mathrm{mM}$ Imidazol e a LIC10793 foi eluida com $250 \mathrm{mM}$ de Imidazol (Figura 33).

A proteína LIC10191 recombinante purificada no laboratório se mostrou solúvel e estável, não precipitando quando armazenada a $4{ }^{\circ} \mathrm{C}$ ou em TA. A análise da estrutura secundária por dicroísmo circular (DC) indicou que proteína tem $\alpha$ hélice como estrutura predominante, em comparação com as curvas indicadas nos estudos de Kelly et al. (2005) A variação de temperatura no ensaios de DC indicou a desnaturação da proteína em torno de 50 ${ }^{\circ} \mathrm{C}$. Elevando a temperatura até $80{ }^{\circ} \mathrm{C}$ e então retornando para $20{ }^{\circ} \mathrm{C}$ observa-se reestruturação parcial da proteina (Figura 34). A solubilidade e estabilidade da proteína em diversas temperaturas são características desejáveis para uma vacina.

As proteínas LIC11227 e LIC12302 foram expressas na forma insolúvel e foram purificadas a partir da fração insolúvel do extrato bacteriano (Figura 35). A proteína LIC11227 foi solubilizada com uréia $8 \mathrm{M}$ e se ligou fracamente à coluna. Foi eluída com o tampão de eluição com uréia $8 \mathrm{M}$ e baixas concentrações de imidazol, $20 \mathrm{mM}, 50 \mathrm{mM}$ e 80 mM. A proteína LIC12302 também foi solubilizada com uréia 8 M e da coluna de IMAC com tampão de eluição com uréia $8 \mathrm{M} \mathrm{e} \mathrm{imidazol} 150 \mathrm{mM}$.

As frações mais concentradas e menos contaminadas foram dialisadas contra PBS para a retirada dos sais. As proteínas LIC11227 e LIC12302 precipitaram no processo de retirada da uréia e foram utilizadas apenas em testes de western blot.

Não foi possível purificar a proteína LIC13101 devido à baixa expressão em E. coli. Essa proteína possui alta massa molecular, $127 \mathrm{kDa}$, o que possivelmente se relacione com a baixa expressão.

A proteína recombinante ankB de Leptospira interrogans sorovar Copenhageni foi incluída anteriormente em ensaio de imunização e desafio realizado no laboratório pela aluna de mestrado Tatiana R. Fraga, no qual se utilizou um pool de sete proteínas. Nesse ensaio houve proteção parcial de 30\% dos animais (FRAGA, 2009). Decidimos testar a resposta imune a este antígeno quando apresentado in vivo por salmonela. 
Os clones de E. coli e salmonela com pAEsoxLIC12033 haviam sido construídos durante o mestrado de Tatiana R. Fraga. Verificamos que a proteína AnkB era expressa em maior quantidade no clone de salmonela do que no clone de E. coli e na forma solúvel. Purificamos a proteína por IMAC a partir do sobrenadante dos extratos de cultivo de salmonela induzido por PQ. A proteína foi eluída com tampão contendo $500 \mathrm{mM}$ de imidazol. Apesar da alta expressão, a recuperação da proteína na purificação foi baixa (Figura 36). A proteína purificada foi dialisada contra tampão PBS para imunização de hamsters. Usamos este mesmo clone de salmonela para a imunização dos animais. 


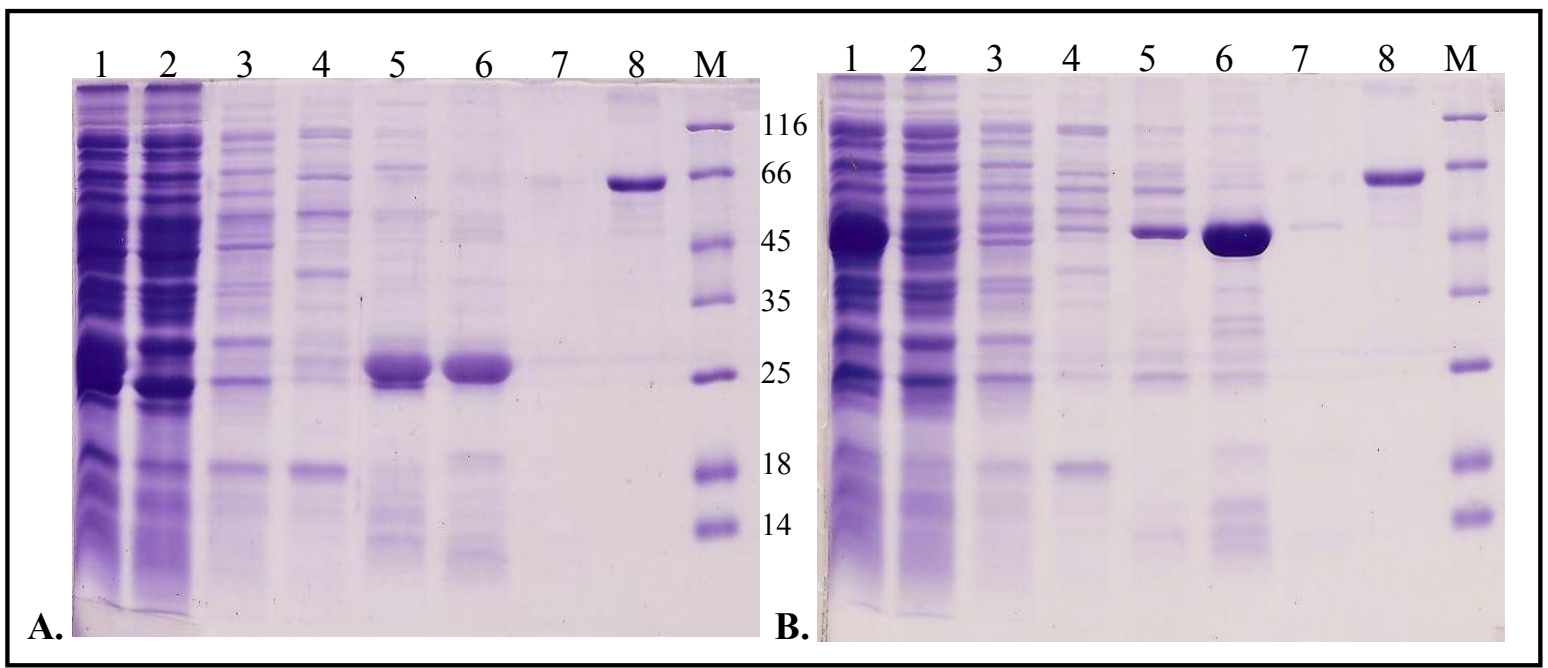

Figura 33 - Análise da purificação por IMAC das proteínas LIC10191 e LIC10793 por SDSPAGE. A) LIC10191 e B) LIC10793. Canaletas: 1- sobrenadante do extrato bacteriano; 2- "flow through"; 3- tampão de reequilíbrio; 4- $20 \mathrm{mM}$ imidazol; 5- $50 \mathrm{mM}$ imidazol; 6500 mM imidazol fração A, 7- 500 mM imidazol fração B e 8- padrão de albumina $1 \mu \mathrm{g}$.

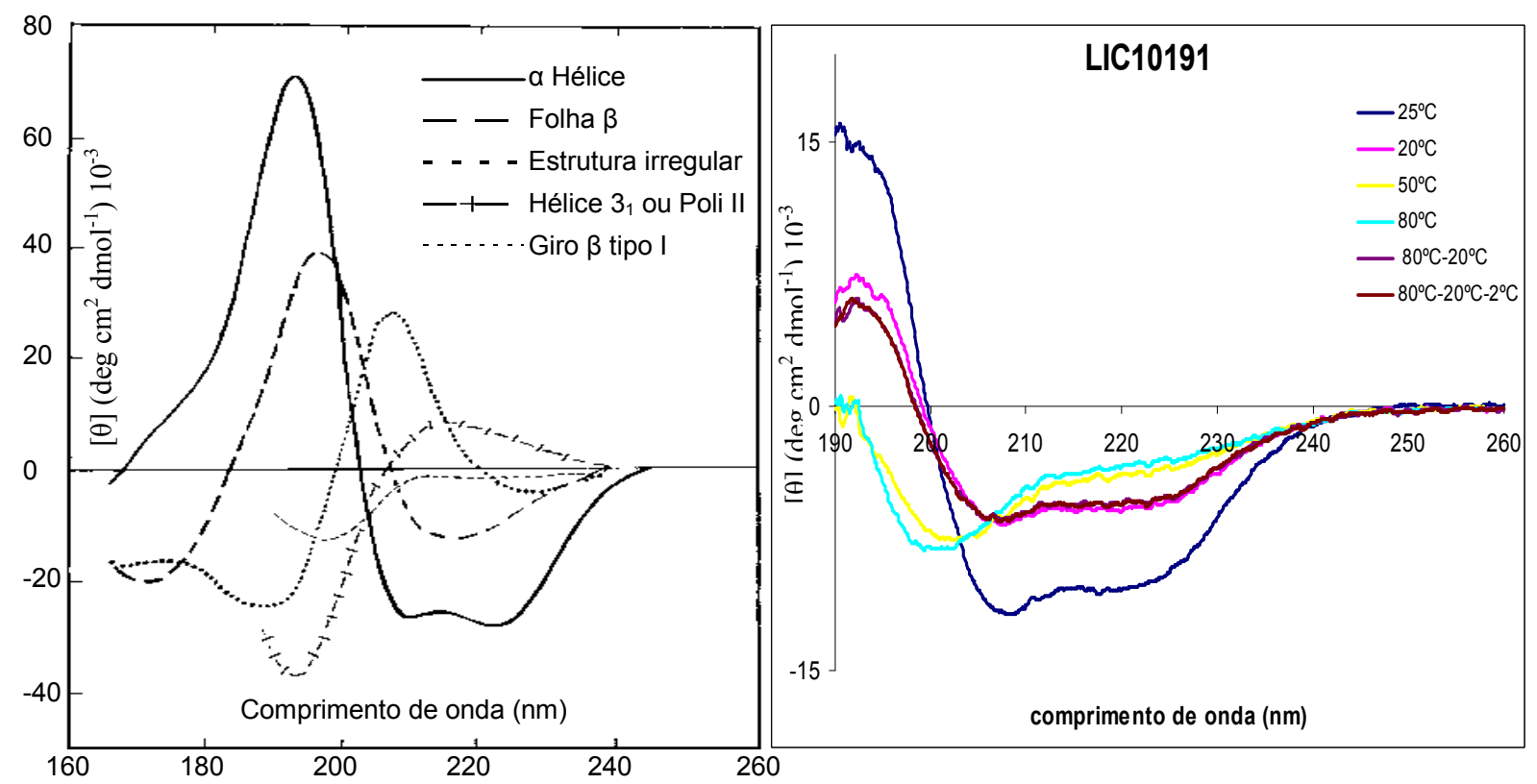

Figura 34 - Análise da integridade das estruturas secundárias da proteína recombinante LIC10191 purificada. Curvas de espectrometria de luz polarizada utilizando o espectrofotômetro JASCO J-810. As temperaturas foram variadas para testar a estabilidade da proteína. A figura da esquerda mostra as curvas padrão para cada tipo de estrutura.

FONTE: adaptado de KELLY et al. (2005). 


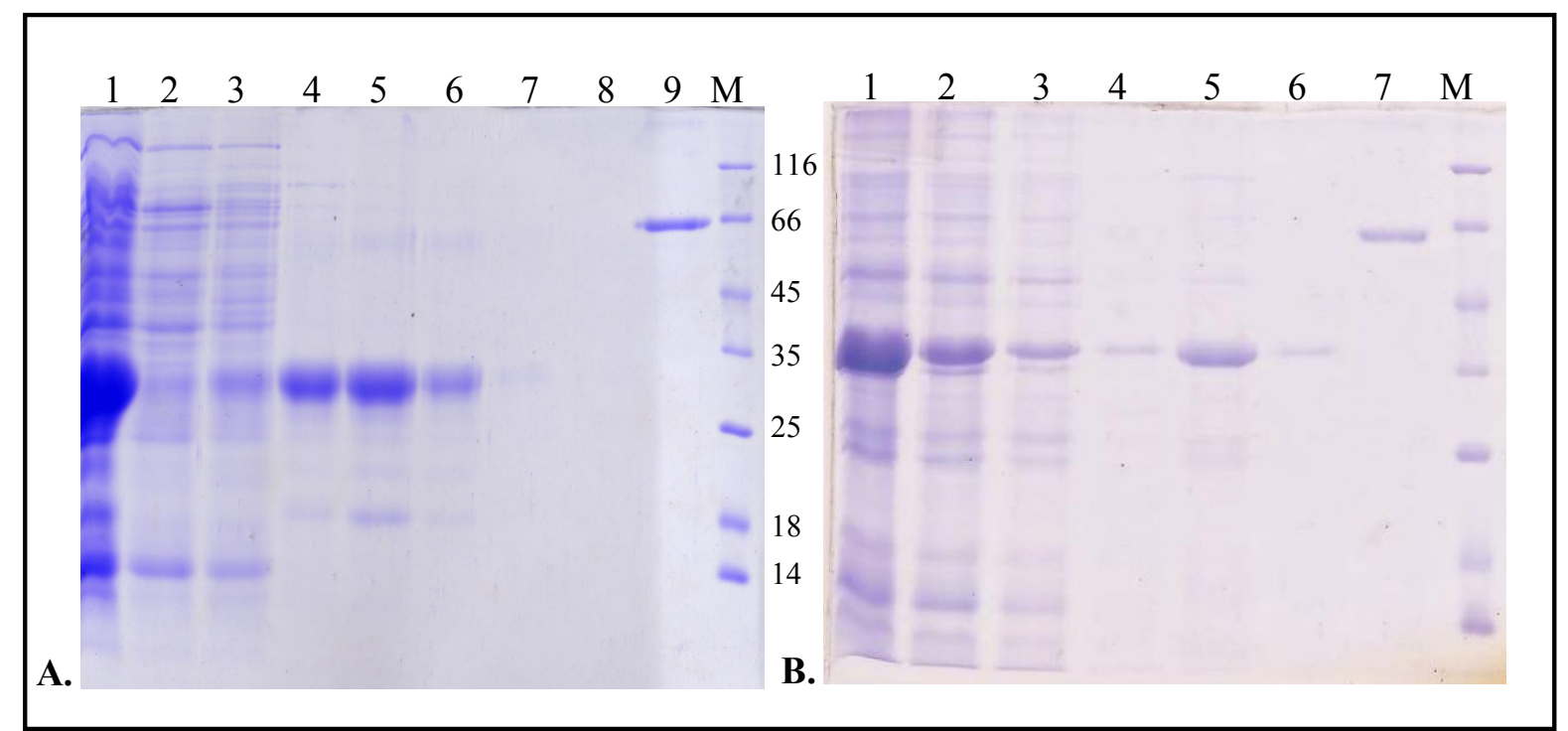

Figura 35 - Análise da purificação por IMAC das proteínas LIC11227 e LIC12302 por SDSPAGE. M- marcador de massa molecular A) LIC11227. Canaletas: 1- fração insolúvel do extrato bacteriano solubilizado em $8 \mathrm{M}$ uréia; 2- "flow through"; 3- lavagem com tampão de equilíbrio; 4- lavagem com tampão com $20 \mathrm{mM}$ imidazol; 5- $50 \mathrm{mM}$ imidazol; 6- 80 mM imidazol; 7- $100 \mathrm{mM}$ imidazol; 8- $150 \mathrm{mM}$ imidazol; 9- padrão de albumina $1 \mu \mathrm{g}$. B) LIC12302 Canaletas: 1- fração insolúvel do extrato bacteriano solubilizada em $8 \mathrm{M}$ uréia; 2- "flow through"; 3- tampão de equilíbrio; 4- $10 \mathrm{mM}$ imidazol; 5- $150 \mathrm{mM}$ imidazol; 6$250 \mathrm{mM}$ imidazol e 7- padrão de albumina $1 \mu \mathrm{g}$.

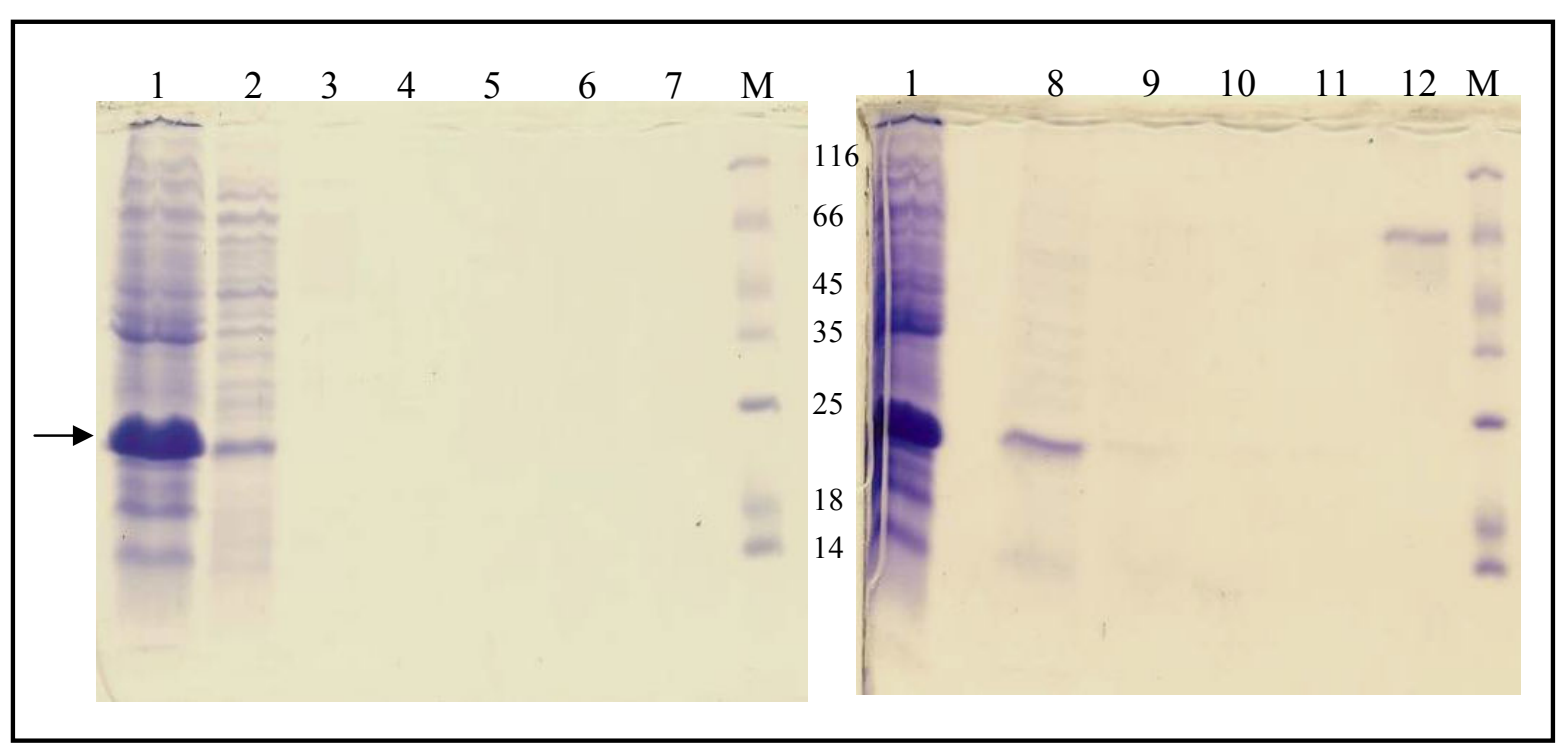

Figura 36 - Análise da purificação por IMAC da LIC12033 (ankB) por SDS-PAGE. Canaletas: 1sobrenadante aplicado a coluna; 2- "flow through"; 3- tampão de reequilíbrio; 4- $10 \mathrm{mM}$ imidazol; 5- $20 \mathrm{mM}$ imidazol; 6- $50 \mathrm{mM}$ imidazol, 7- $80 \mathrm{mM}$ imidazol, 8- 500mM imidazol fração A, 9- 500mM imidazol fração B, 10- 500mM imidazol fração C, 11$500 \mathrm{mM}$ imidazol fração D e 12- padrão de albumina $2 \mu \mathrm{g}$. M- marcador de massa molecular. 


\subsection{Reconhecimento dos antígenos purificados por anticorpos IgG e IgM do soro de paciente de leptospirose}

O reconhecimento das proteínas recombinantes por anticorpos presentes no soro de pacientes de leptospirose indicaria que essas proteínas têm propriedades antigênicas, sendo expressa pela bactéria e apresentada ao sistema imune do hospedeiro durante a infecção. Também indicaria que a proteína recombinante estaria retendo epitopos da proteína nativa.

Analisamos, por ensaios de western blot, o reconhecimento de quinze proteínas recombinantes purificadas pelo soro de um paciente com leptospirose. Além das proteínas que purificamos, testamos 11 proteínas purificadas pelas estudantes do grupo, Luana Melo Lopes e Tatiana Rodrigues Fraga, e as proteínas Lip32 e HlyX purificadas por estudantes do Dr. Paulo Lee Ho.

O soro do paciente de leptospirose foi colhido ao dar entrada no hospital, na fase aguda da doença. $O$ soro avaliado em laboratório de análises clínicas por teste de imunoflourescência indireta determinou títulos 1:100 de anticorpos IgG e 1:1600 de anticorpos IgM específicos contra leptospira. $\mathrm{O}$ valor de referência para o diagnóstico positivo no teste dos dois anticorpos é 1:100. O isotipo IgG não é considerado um bom marcador para diagnóstico de leptospirose e é raramente usado. Anticorpos IgM são predominantes e podem ser detectados mesmo após vários meses da infecção. Além disso, a sensibilidade do teste de IgM é maior, permitindo detecção de 70\% dos casos em 5 dias e mais de 95\% em 2 semanas.

Para o western blot as proteínas purificadas foram separadas por SDS-PAGE, transferidas para membranas de PVDF e estas foram coradas com solução de Ponceau para a verificar a transferência. As membranas foram tratadas como descrito em Materiais e Métodos 3.17 e expostas ao soro do paciente na diluição 1:100. Para detecção dos anticorpos ligados usamos anticorpos anti-IgG humano conjugado com peroxidase na diluição 1:20000. Em outra membrana foi utilizado anticorpos anti-IgM humano conjugado com peroxidase na diluição 1:10000. A revelação dos dois testes foi feita com DAB. As membranas são apresentadas nas Figuras 37 e 38.

As proteínas usadas no ensaio de western blot com soro de paciente de leptospirose e suas respectivas massas moleculares estão listadas na Tabela 2, bem como uma avaliação da intensidade de reconhecimento pela intensidade da banda determinada.

Observamos que as proteínas LIC11227, LIC11352 e LIC12631, foram fortemente reconhecidas por anticorpos IgG contidos no soro de um paciente infectado por leptospira. As proteínas LIC10191, LIC10793, LIC10325 e LIC12660 foram reconhecidas mais fracamente. 
Um dado interessante foi o forte reconhecimento da proteína LIC11227 apesar da pouca massa de proteína na membrana. Não houve correlação entre quantidade de antígeno na membrana e reconhecimento por anticorpos, refletindo a esperada diferença de antigenicidade das proteínas. Não podemos precisar porque as proteinas são detectadas de maneira diferente quando as membranas são coradas com Ponceau, se os antígenos não se fixaram à membrana, senão saíram do gel ou se o Ponceau cora de maneira diferente cada proteína.

Tabela 3 - Proteínas recombinantes utilizadas nos testes de western blot suas massas moleculares, intensidade do reconhecimento por anticorpos do soro de paciente de leptospirose

\begin{tabular}{ccccc}
\hline \multirow{2}{*}{ Gene } & Característica da proteína & \multicolumn{2}{c}{$\begin{array}{c}\text { Massa da } \\
\text { proteina } \\
\text { kDa }\end{array}$} & \multicolumn{2}{c}{$\begin{array}{c}\text { Reconhecimento } \\
\text { por anticorpos }\end{array}$} \\
& IgG & IgM \\
\hline LIC10191 & OmpAL21 proteína associada peptídeoglicano & 20,3 & + & + \\
LIC10793 & Antígeno de superfície & 49,2 & ++ & ++ \\
LIC11227 & OmpL17 proteína periplasmática conservada & 28,5 & +++ & ++ \\
LIC12302 & O-sialoglicoproteína endopeptidase M22 & 38,9 & - & - \\
LIC11352 & LipL32 HAP-1 & 30,7 & +++ & +++ \\
LIC10325 & HlyX-hemolisina domínios TPR & 42,3 & + & ++ \\
LIC12631 & Sph2 - Esfingomielinase & 72,2 & +++ & +++ \\
LIC12659 & VapB - associada a virulência & 10,1 & + & + \\
LIC12660 & VapC - associada a virulência & 16,4 & - & - \\
LIC10508 & LipL23 lipoproteína da ilha extra & 22,3 & $\mathrm{X}$ & + \\
LIC10509 & LipL22 & 21,9 & $\mathrm{X}$ & - \\
LIC10537 & OmpA76 proteína periplasmática & 76,3 & $\mathrm{X}$ & + \\
LIC10657 & SphH - Esfingomielinase H & 58,3 & $\mathrm{X}$ & - \\
LIC11040 & Sph4 - Esfingomielinase & 22,8 & $\mathrm{X}$ & - \\
LIC12033 & ankB - Domínios ankirina & 21,8 & $\mathrm{X}$ & + \\
\hline
\end{tabular}

+: reconhecido/ -: não reconhecido/ X: não realizado

Podemos observar o reconhecimento das proteínas LIC10508, LIC10537, LIC12033, LIC12631, LIC12659, LIC11227, LIC10793, LIC10191, LIC11352 e LIC10325 pelos anticorpos IgM presentes no soro de um paciente infectado por leptospira. As proteínas LIC10509, LIC10657, LIC11040, LIC12660 e LIC12302 não foram reconhecidas. A proteína LIC12631 (Sph2) sofreu degradação após a purificação, como pode ser visto no gel corado com comassie e no reconhecimento pelo soro, gerando várias bandas e determinando um arraste na membrana revelada. O reconhecimento das proteínas pelo soro de um paciente 
infectado por leptospira indica que estas proteínas são antigênicas, ou seja, são expressas pela bactéria durante a infecção. A análise das massas de proteína transferida para a membrana e a intensidade das bandas após a revelação mostra que algumas proteínas foram melhores reconhecidas por anticorpos IgM sugerindo que estes são mais abundantes durante a infecção. As proteínas reconhecidas fortemente pelos anticorpos $\operatorname{IgM}$ de um paciente infectado seriam bons candidatos a testes de diagnóstico. A Tabela 3 mostra o reconhecimento das proteínas no soro de um paciente de leptospirose. 


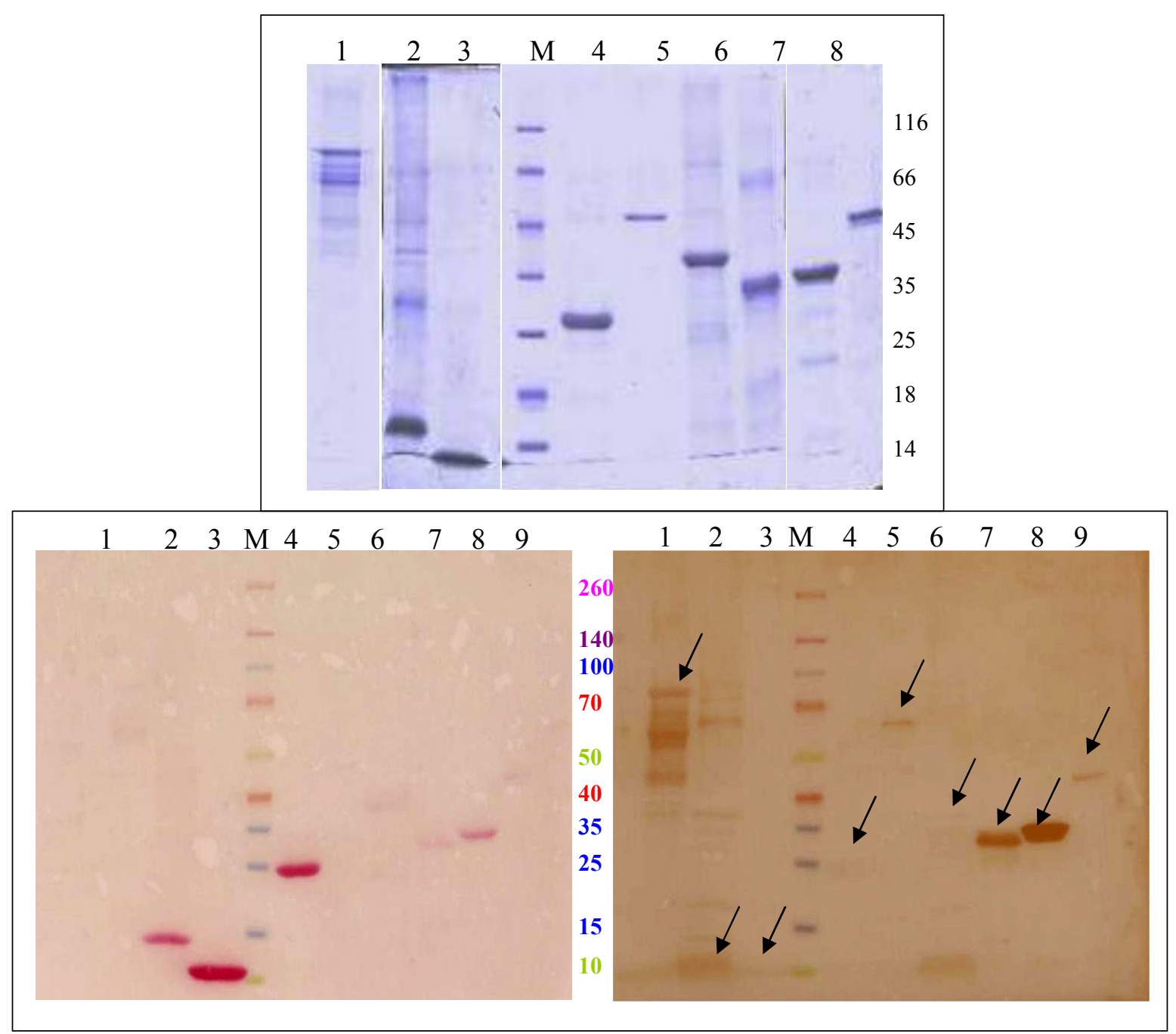

Figura 37 - Reconhecimento das proteínas recombinantes por anticorpos IgG do soro de um paciente de leptospirose. A) SDS-PAGE corado com comassie-blue; B) membrana corada com ponceau após a transferência das proteinas e C) membrana exposta aos anticorpos e revelada com DAB. Canaletas: 1- LIC12631 (Sph); 2- LIC12660 (VapC); 3- LIC12659 (VapB); 4- LIC10191 (Loa22); 5- LIC10793 (Lp49); 6- LIC12302; 7- LIC 11227; 8LIC11352 (Lip32) e 9- LIC10325 (HlyX). M- marcador de massa molecular. 


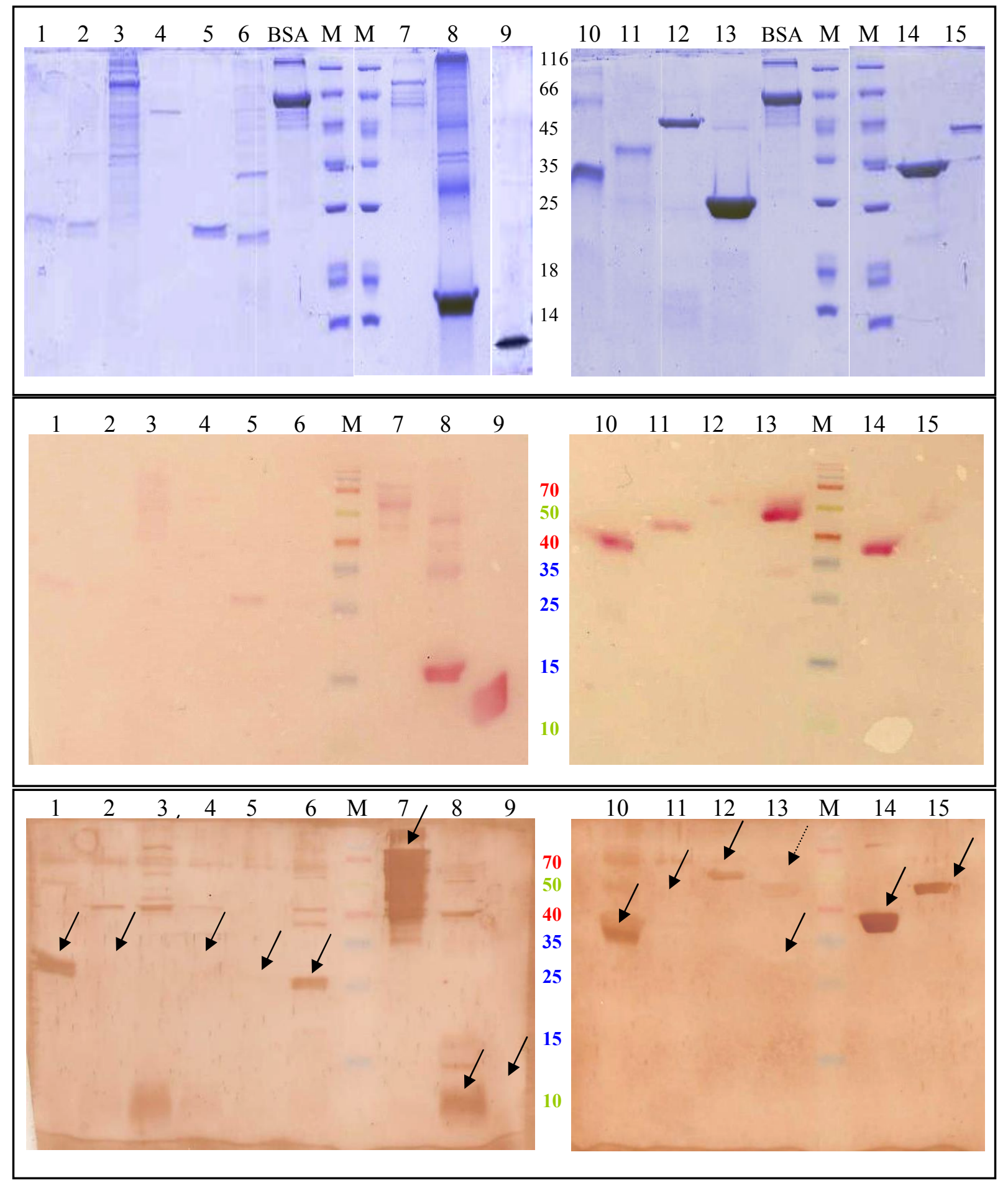

Figura 38 - Reconhecimento das proteínas recombinantes por anticorpos IgM do soro de um paciente de leptospirose. A) SDS-PAGE corado com comassie-blue; B) membrana corada com ponceau após a transferência das proteínas e C) membrana exposta ao soro e a anticospos anti-IgM, revelada com DAB. Canaletas: 1- LIC10508 (LipL23); 2- LIC10509 (LipL22); 3- LIC10537 (OmpA76); 4- LIC10657 (SphH); 5- LIC11040 (Sph4); 6LIC12033 ; 7- LIC12631 (Sph); 8- LIC12659 (VapB); 9- LIC12660 (VapC); 10LIC11227; 11- LIC12302; 12- LIC10793 (Lp49); 13- LIC10191 (Loa22); 14- LIC11352 (Lip32) e 15- LIC10325 (HlyX). M- marcador de massa molecular. 


\subsection{Persistência das salmonelas no hospedeiro, toxicidade a apresentação de antígenos}

Testes feitos anteriormente no laboratório, de imunização de camundongos com salmonelas vacinais recombinantes mostraram que há persistência das salmonelas no baço e linfonodos dos animais por ao menos quinze dias após as imunizações. Segundo Tomita (2005), após quinze dias da inoculação de $3 \times 10^{7}$ bactérias via intraperitoneal, houve recuperação de aproximadamente $7 \times 10^{4}$ bactérias no baço dois dias após inoculação e recuperação de $5 \times 10^{2}$ bactérias no baço dos animais 14 dias após inoculação. Esses ensaios mostraram também que houve expressão da proteína heteróloga, o fragmento $\mathrm{C}$ de toxina tetânica (FC), in vivo, uma vez que após a imunização de camundongos com a salmonelas-FC, a despeito do baixo título de $\operatorname{IgG}$ anti-toxoide tetânico, os animais sobreviveram ao desafio com a toxina, indicando que ocorreu resposta humoral suficientes para neutralização da toxina (não descartando a possibilidade de que outros componentes de resposta imune tivessem sido induzidos). Os títulos de IgG anti-antigenos apresentados por salmonelas são sempre mais baixos em comparação com a imunização com proteínas purificadas. É descrito na literatura que a resposta imune a antígenos apresentados por salmonelas vivas é mais complexa, com componentes humoral, celular e de mucosa (HOISETH e STOCKER, 1981).

Em nossos ensaios de imunização de camundongos observamos morte dos animais em alguns grupos. Por isso decidimos analisar alguns aspectos da imunização com salmonelas, reproduzindo a avaliação da persistência das bactérias in vivo e possíveis efeitos tóxicos do microrganismo em função da dose administrada. Houve necessidade de precisar a dose de salmonelas vazias, para avaliar possíveis efeitos tóxicos dos antigenos apresentados. Elaboramos uma curva de dose de salmonela em camundongos usando a linhagem vacinal SL3261 com o vetor pAEsox (sem inserto). Foram imunizados 4 grupos experimentais com 5 camundongos por grupo, recebendo diferentes doses da salmonela. Considerando que uma cultura de salmonelas com $\mathrm{DO}_{600 \mathrm{~nm}} 0,5$ tem $10^{8}$ células por $\mathrm{ml}$, foram administradas as doses $10^{8}, 5 \times 10^{7}, 3 \times 10^{7}$, e $10^{7}$ UFC em $200 \mu 1$ por via intraperitoneal. Os animais que receberam a maior dose e um animal da segunda maior dose morreram antes dos 12 dias. Observamos efeitos adversos, como febre, pêlo arrepiado, diarréia e pouca mobilidade, nos animais de todos os grupos, proporcional a dose administrada. Após 12 dias da inoculação, dois animais de cada grupo foram sacrificados e os baços macerados em homogeneizadores de vidro contendo $1 \mathrm{ml}$ de solução salina estéril. Plaqueamos $100 \mu \mathrm{l}$ dos extratos dos baços macerados e 100 $\mu 1$ de uma diluição 1:10 em placas 2YT-ágar contendo ampicilina. As placas foram 
incubadas a $37^{\circ} \mathrm{C}$ por 16 horas para o crescimento das colônias. O resultado das contagens das colônias está apresentado na Tabela 4.

Tabela 4 - Doses de salmonela administradas nos camundongos, sobrevivência e recuperação das bactérias do baço após 12 dias da inoculação.

\begin{tabular}{ccc}
\hline $\begin{array}{c}\text { Dose de } \\
\text { bactérias/250 } \boldsymbol{\mu l}\end{array}$ & $\begin{array}{c}\text { Sobrevivência após 12 } \\
\text { dias da inoculação }\end{array}$ & $\begin{array}{c}\text { Número UFC recuperadas } \\
\text { no baço (por ml de } \\
\text { macerado) }\end{array}$ \\
\hline $10^{8}$ & $0 / 5$ & - \\
$5 \times 10^{7}$ & $4 / 5$ & Muitas \\
$3 \times 10^{7}$ & $5 / 5$ & 2450 \\
$10^{7}$ & $5 / 5$ & 1170 \\
\hline
\end{tabular}

Os resultados deste ensaio indicam que as salmonelas persistem no hospedeiro por ao menos 12 dias. As salmonelas atenuadas não devem colonizar ou se multiplicar no hospedeiro devido à indisponibilidade de aminoácidos aromáticos e a sua deficiência em sintetizá-los, por isso é esperado o decaimento no número de UFCs e a recuperação é proporcional à dose administrada. Ensaios anteriores do grupo mostraram um máximo de recuperação de salmonelas no baço dois dias após a administração e $10 \%$ persistiam 14 dias depois. O resultado deste ensaio foi utilizado na determinação da dose a ser administradas em nossos ensaios de imunização, $3 \times 10^{7}$ bactérias por via intraperitoneal. Este ensaio também é importante para avaliar possível variação da toxicidade da salmonela quando expressando antígenos de leptospira.

4.8 Ensaios de imunização em camundongos para obtenção de soros contra as proteínas recombinantes e avaliação da imunização com salmonelas recombinantes.

4.8.1 Imunização de camundongos com as proteínas LIC10191 e LIC10793 e as salmonelas SLLIC10191 e SLLIC10793 via ip, in e vo.

Para obtenção de soros reativos, camundongos foram imunizados com as proteínas recombinantes purificadas LIC10191 e LIC10793. Paralelamente foram feitos testes iniciais de imunização com salmonelas recombinantes, SLLIC10191 e SLLIC10793, para verificar a expressão das proteínas in vivo. Os objetivos desse ensaio eram a obtenção de soros com 
anticorpos contra as proteínas em estudo, verificar a indução de anticorpos específicos pelas salmonelas recombinantes e também observar possíveis efeitos adversos da salmonela vacinal carregando os antigenos. Neste ensaio testamos a administração da salmonela recombinante por três vias distintas, intraperitoneal (ip), intranasal (in) e via oral (vo). As doses de imunização com salmonelas ou proteínas purificadas estão na Tabela 5.

Tabela 5 - Grupos de camundongos imunizados para obtenção de anticorpos e análise da resposta a salmonelas recombinantes.

\begin{tabular}{cccc}
\hline Grupo & Imunógeno & $\begin{array}{c}\text { via de } \\
\text { imunização }\end{array}$ & Dose / animal \\
\hline 1 & Salina & ip & ------ \\
2 & SL3261 vazia & ip & $3 \times 10^{7}$ bactérias \\
3 & proteína LIC10191 & ip & $5 \mu \mathrm{g}$ \\
4 & proteína LIC10793 & ip & $5 \mu \mathrm{g}$ \\
5 & SLLIC10191 & ip & $3 \times 10^{7}$ bactérias \\
6 & SLLIC10191 & vo & $3 \times 10^{9}$ bactérias \\
7 & SLLIC10191 & in & $1,8 \times 10^{8}$ bactérias \\
8 & SLLIC10793 & ip & $3 \times 10^{7}$ bactérias \\
9 & SLLIC10793 & vo & $3 \times 10^{9}$ bactérias \\
10 & SLLIC10793 & in & $1,8 \times 10^{8}$ bactérias \\
\hline
\end{tabular}

\subsubsection{Determinacão de anticorpos IgG no soro dos camundongos imunizados, por} ELISA

Os animais foram imunizados com quatro doses de antígenos em intervalos de quinze dias. Sangue dos animais foi coletado dois dias antes de cada imunização e quinze dias após a última imunização para análise da presença de anticorpos por ELISA (Figuras 39 e 40).

Os objetivos dos ensaios de imunização de camundongos eram obter soros com anticorpos contra as proteínas em estudo, verificar a indução de anticorpos contra antígenos específicos apresentados por salmonelas recombinantes e também observar possíveis efeitos adversos das salmonelas vacinais.

Os resultados do ELISA (Figura 39) mostram que a proteína LIC10191 purificada induziu resposta imune importante, atingindo titulos de mais de 1.000.000. Foi possível observar que o título subiu após cada dose e que a primeira dose já definiu boa resposta.

As curvas de ELISA indicam que houve uma tenue resposta de anticorpos especificos após duas inoculações com salmonela por via nasal e intraperitoneal.

Os gráficos de ELISA com soros anti LIC10793 (Figura 40 A, B, C e D) indicam que a proteína recombinante purificada induziu resposta imune atingindo titulo da ordem de 
100.000. A imunização com SLLIC10793 induziu resposta atingindo títulos de 10.000. Um dado interessante, diferente do que temos observado, foi a obtenção de maior resposta na administração da salmonela por via oral do que por via intranasal. A proteína LIC10191 apresentou-se mais imunogênica que a LIC10793 como proteína purificada, ao contrário do observado com a apresentação dos antígenos pelas salmonelas recombinantes, quando SLLIC10191 apresentou menor resposta. A imunização com a SLLIC10191 via intraperitoneal gerou um pouco mais de anticorpos do que as outras vias testadas. As primeiras imunizações com salmonelas parecem mais efetivas que as subseqüentes, sugerindo que a resposta imune induzida contra a salmonela na primeira dose possa afetar a persistência da bactéria nas doses subsequentes. 

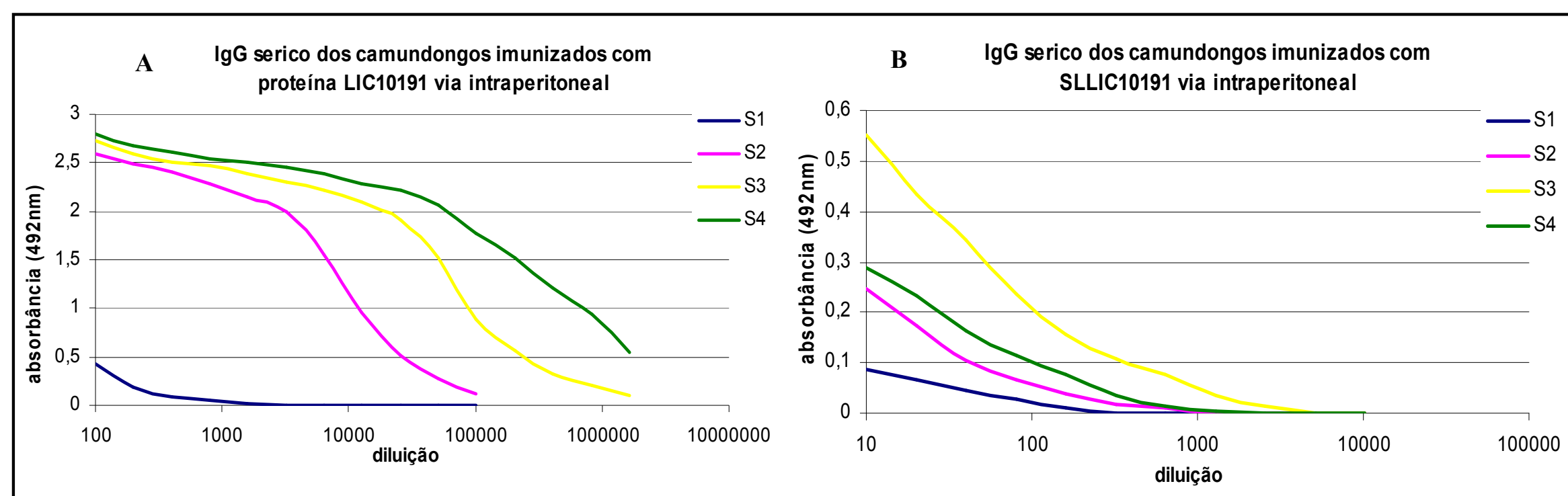

C IgG serico dos camundongos imunizados com SLLIC10191 via intranasal
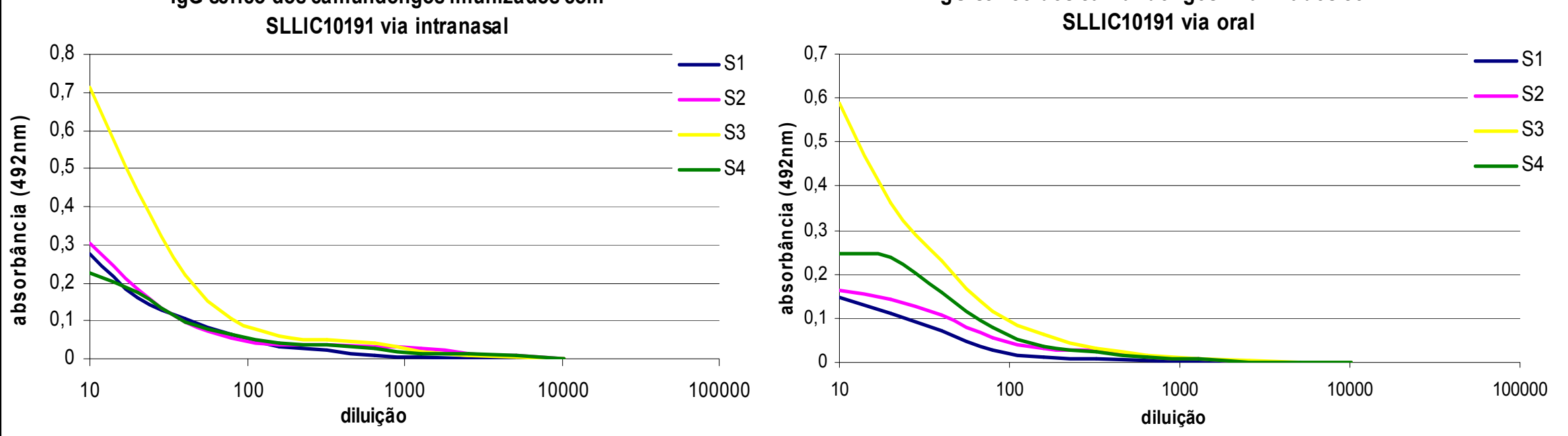

Figura 39 - Análise de IgG anti-LIC10191 no soro de camundongos imunizados. Os soros foram preparados a partir das sangrias realizadas quinze dias após cada das 4 imunizações (S1, S2, S3 e S4) com A - a proteína purificada (via intraperitoneal), B, C e D - animais imunizados com SLLIC10191 B- por via intraperitoneal C - por via intranasal e D - por via oral. 


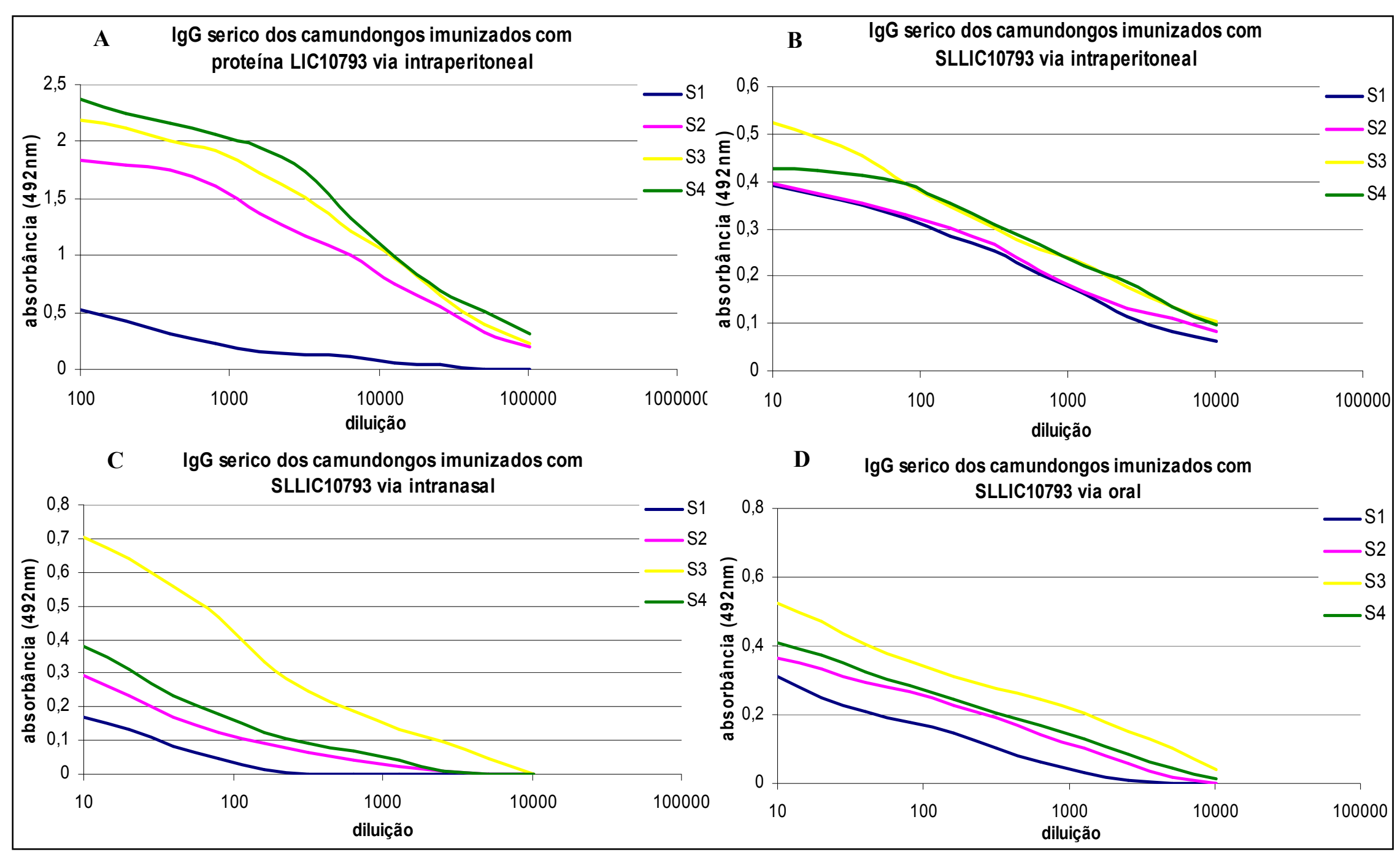

Figura 40 - Análise de IgG anti-LIC10793 no soro de camundongos imunizados. Os soros foram preparados a partir das sangrias realizadas quinze dias após cada das 4 imunizações (S1, S2, S3 e S4) com: A - proteína purificada LIC10793 (via intraperitoneal), B, C e D - animais imunizados com SLLIC10793, B- por via intraperitoneal, C - por via intranasal, e D - por via oral. 


\subsubsection{Avaliação do reconhecimento dos antígenos por anticorpos específicos dos soros de camundongos imunizados, por western blot}

Os soros dos camundongos imunizados foram testados quanto ao reconhecimento das proteínas recombinantes por ensaio de western blot (Figura 41). Observamos que as proteínas purificadas são fortemente reconhecidas pelo soro dos animais imunizados com as mesmas.

A proteína LIC10191 também foi reconhecida pelo soro dos animais imunizados com a SLLIC10191 pelas vias intraperitoneal, intranasal e oral (Figuras 41E, 41F e 41G). O reconhecimento determina bandas tênues no Western blot, um resultado esperado considerando os baixos títulos de IgG observados nos ELISAs. Esses dados indicam que a proteína foi expressa in vivo pela salmonela após administração pelas vias intraperitoneal, oral e intranasal.

A proteína LIC10793 foi reconhecida pelo soro dos animais imunizados via intraperitoneal com a SLLIC10793, porém não foi reconhecida pelo soro dos animais após administração da salmonela por via oral e intranasal (Figura 41I), embora os ELISAs indicassem títulos mais elevados em comparação com a imunização com a SLLIC10191. Como pode ser observado nas membranas coradas com Ponceau, há baixa quantidade da proteína LIC10793 transferida (ou fixada) para a membrana, dificultando a detecção do reconhecimento por anticorpos induzidos por SLLIC10793, mas suficiente para o reconhecimento pelo soro dos animais imunizados com a proteína purificada. A Tabela 6 resume o resultado obtido nos testes de western blot.

Tabela 6 - Intensidade relativa das bandas de reconhecimento de IgG contra as proteínas LIC10191 e LIC10793 purificadas. Avaliação dos resultados da Figura 41.

\begin{tabular}{|c|c|c|c|c|}
\hline \multirow{2}{*}{ Grupo } & \multirow{2}{*}{$\begin{array}{l}\text { Soro dos grupos de } \\
\text { imunização }\end{array}$} & \multirow{2}{*}{$\begin{array}{c}\text { via de } \\
\text { imunização }\end{array}$} & \multicolumn{2}{|c|}{ Reconhecimento de anticorpos IgG } \\
\hline & & & LIC10191 & LIC0793 \\
\hline 1 & Salina & ip & - & - \\
\hline 2 & SL3261 vazia & ip & - & - \\
\hline 3 & proteína LIC10191 & ip & +++ & $X$ \\
\hline 4 & proteína LIC10793 & ip & $\mathrm{X}$ & ++ \\
\hline 5 & SLLIC10191 & ip & ++ & $\mathrm{X}$ \\
\hline 6 & SLLIC10191 & vo & + & $\mathrm{X}$ \\
\hline 7 & SLLIC10191 & in & + & $\mathrm{X}$ \\
\hline 8 & SLLIC10793 & ip & $\mathrm{X}$ & + \\
\hline 9 & SLLIC10793 & vo & $\mathrm{X}$ & - \\
\hline 10 & SLLIC10793 & in & $\mathrm{X}$ & - \\
\hline
\end{tabular}




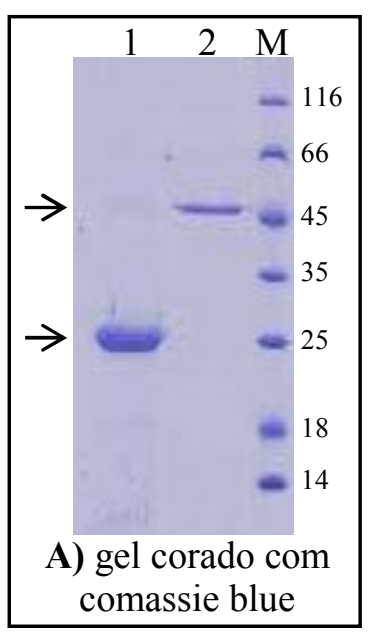

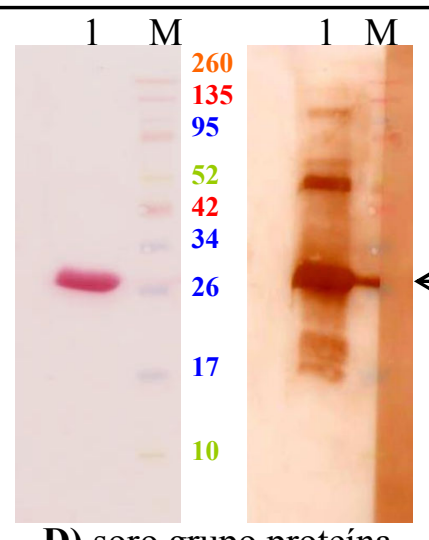

D) soro grupo proteína LIC10191 purificada diluição $1: 1000$

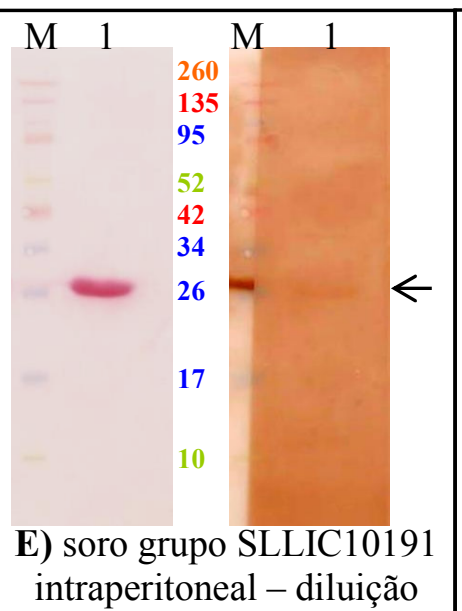

intraperitoneal - diluição $1: 100$

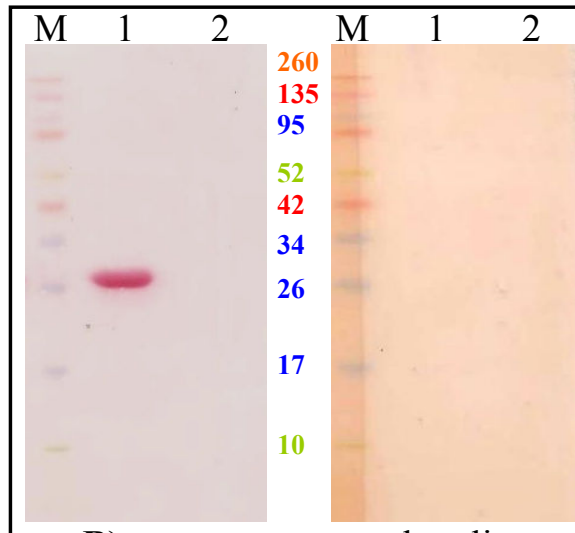

B) soro grupo controle salina diluição 1:1000

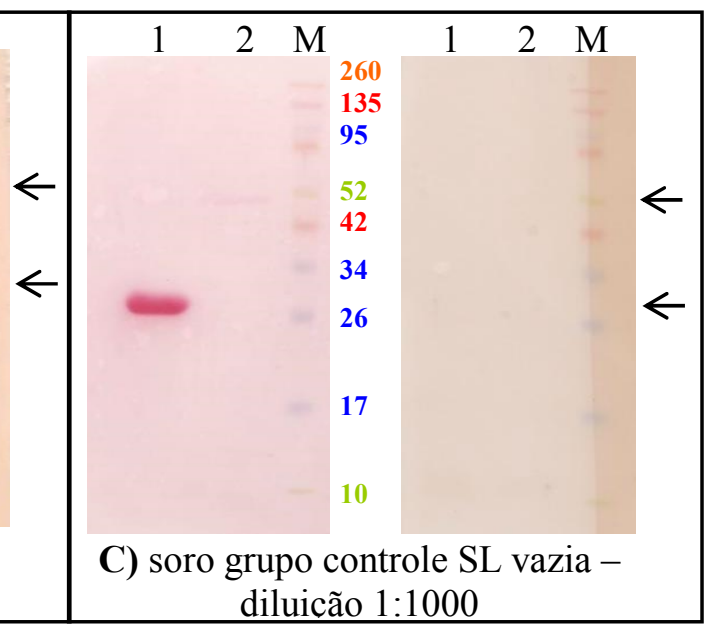

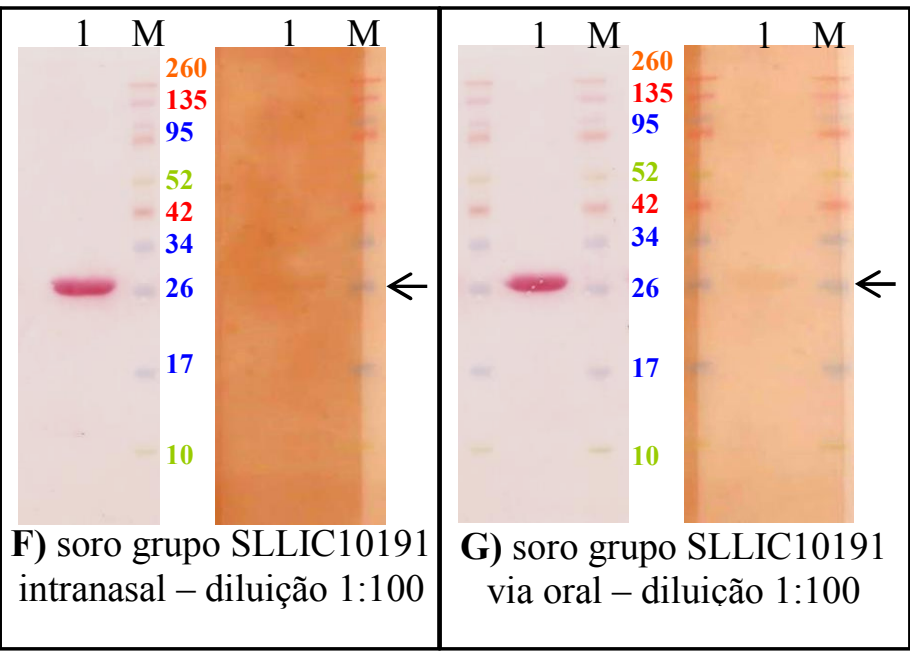

$2 \mathrm{M}$

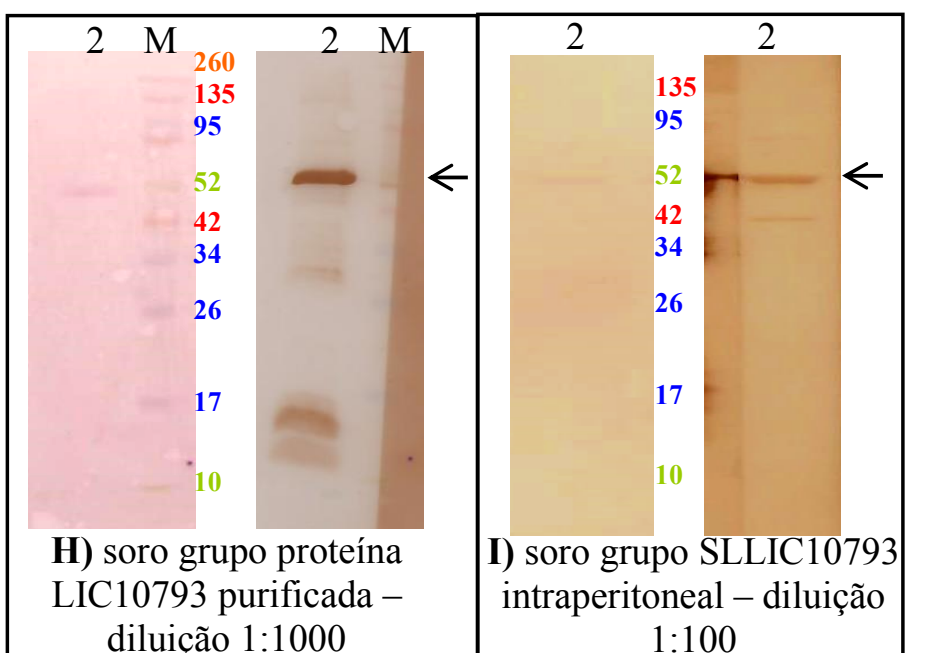

Figura 41 - Análise de anticorpos específicos nos soros de camundongos imunizados com as proteínas LIC10191 e LIC10793 ou com as salmonelas SLLIC10191 e SLLIC10793, por western blot. M - marcador de massa molecular, canaletas: 1 - LIC10191 purificada e 2- LIC10793 purificada. Em cada quadro B até I apresentamos as membranas coradas com Ponceau após a transferência das proteinas e as membranas reveladas com DAB após a incubação com os soros de animais imunizados com 3 doses dos imunógenos indicados. 


\subsubsection{Ensaio de imunização de camundongos com as salmonelas carregando vetores híbridos}

Considerando a toxicidade das salmonelas e a quantidade limitada que poderíamos utilizar para imunizações, desenvolvemos um vetor hibrido para construção de salmonelas capazes de expressar dois antígenos simultaneamente. As salmonelas recombinantes com os plasmídeos híbridos foram usadas na imunização de camundongos para análise de indução de anticorpos. Grupos de 5 animais foram imunizados com 3 doses em intervalos de 15 dias. Os animais que receberam duas doses de salmonela recombinante receberam a última dose com proteína purificada. O objetvo era observar um possível efeito "booster" confirmando a apresentação dos antígenos por salmonela. Os grupos controle salina e controle salmonela receberam uma dose de proteína LIC10191 na última imunização para compararmos os títulos induzidos por uma imunização com proteína com os títulos induzidos por duas doses de salmonela recombinante mais uma dose de proteína.

A Tabela 7 apresenta o protocolo de imunizações.

Tabela 7 - Grupos de imunização e doses administradas em ensaio de imunização com salmonela com vetores híbridos.

\begin{tabular}{|c|c|c|c|}
\hline Grupo de imunização & $1^{\circ}$ dose & $2^{\circ}$ dose & $3^{\circ}$ dose \\
\hline 1. controle salina & - & - & $5 \mu \mathrm{g}$ \\
\hline 2. controle SL3261 & $3 \times 10^{7}$ bactérias & $3 \times 10^{7}$ bactérias & $5 \mu \mathrm{g}$ \\
\hline 3. SLLIC10191_LIC10793 & $3 \times 10^{7}$ bactérias & $-*$ & $-*$ \\
\hline 4. SLLIC10191_10537 & $3 \times 10^{7}$ bactérias & $3 \times 10^{7}$ bactérias & $5 \mu \mathrm{g}$ de cada prot \\
\hline 5. SLLIC10191 & $3 \times 10^{7}$ bactérias & $3 \times 10^{7}$ bactérias & $5 \mu \mathrm{g}$ \\
\hline 6. SLLIC10793 & $3 \times 10^{7}$ bactérias & $3 \times 10^{7}$ bactérias & $5 \mu \mathrm{g}$ \\
\hline 7. SLLIC10537 & $3 \times 10^{7}$ bactérias & $3 \times 10^{7}$ bactérias & $5 \mu \mathrm{g}$ \\
\hline 8. proteína LIC10191 & $5 \mu \mathrm{g}$ & $5 \mu \mathrm{g}$ & $5 \mu \mathrm{g}$ \\
\hline 9. proteína LIC10793 & $5 \mu \mathrm{g}$ & $5 \mu \mathrm{g}$ & $5 \mu \mathrm{g}$ \\
\hline 10. proteína LIC10537 & $5 \mu \mathrm{g}$ & $5 \mu \mathrm{g}$ & $5 \mu \mathrm{g}$ \\
\hline $\begin{array}{l}\text { 11. proteínas LIC10191 e } \\
\text { LIC10793 }\end{array}$ & $5 \mu \mathrm{g}$ de cada prot. & $5 \mu \mathrm{g}$ de cada prot. & $5 \mu \mathrm{g}$ de cada prot. \\
\hline $\begin{array}{l}\text { 12. proteínas LIC10191 e } \\
\text { LIC10793 }\end{array}$ & $5 \mu \mathrm{g}$ de cada prot. & $5 \mu \mathrm{g}$ de cada prot. & $5 \mu \mathrm{g}$ de cada prot. \\
\hline
\end{tabular}




\subsubsection{Determinação de anticorpos IgG no soro dos camundongos imunizados, por}

\section{ELISA}

O sangue dos animais foi coletado 15 dias após as $2^{\circ}$ e $3^{\circ}$ doses e o soro separado para análise de anticorpos por ELISA e western blot. A Figura 42 mostra as análise de anticorpos anti-LIC10191 no soro dos animais imunizados com salmonela recombinante carregando o vetor híbrido pAEsoxLIC10191_10537 e com as proteínas purificadas.

As proteínas purificadas geraram mais anticorpos IgG anti-LIC10191 do que as salmonelas, como esperado (Figura 42). Podemos observar que duas doses de proteína LIC10191 purificada são suficientes para gerar altos títulos de IgG, a terceira dose não elevou o título de IgG em comparação com a segunda dose. Nos grupos que receberam duas proteínas simultaneamente, LIC10191 e LIC10793 ou LIC10191 e LIC10537, observamos um leve aumento de IgG anti-LIC10191 após a terceira dose de proteína.

Podemos observar que os títulos de IgG anti-LIC10191 induzidos pela salmonela recombinante são baixos, mas promoveram o efeito "booster" quando a última dose foi proteína purificada, confirmando a apresentação do antígeno pelas salmonelas (Figura 42). Interessante notar que, com duas doses, a salmonela carregando o vetor híbrido pAEsoxLIC10191_LIC10537 gerou mais IgG anti-LIC10191 do que a salmonela carregando o antígeno sozinho. A Figura 42 mostra que duas doses de proteínas purificadas promove maior resposta de $\operatorname{IgG}$ do que as duas doses com salmonela mais o "booster" de proteína.

Não medimos neste trabalho indícios de resposta imune celular como citocinas ou isotipos IgG2a contra os antígenos apresentados na imunização com salmonela, porém é esperado que a resposta imune seja mais completa, uma vez que é reportado na literatura a capacidade da salmonela de induzir resposta humoral, celular e secretória. 

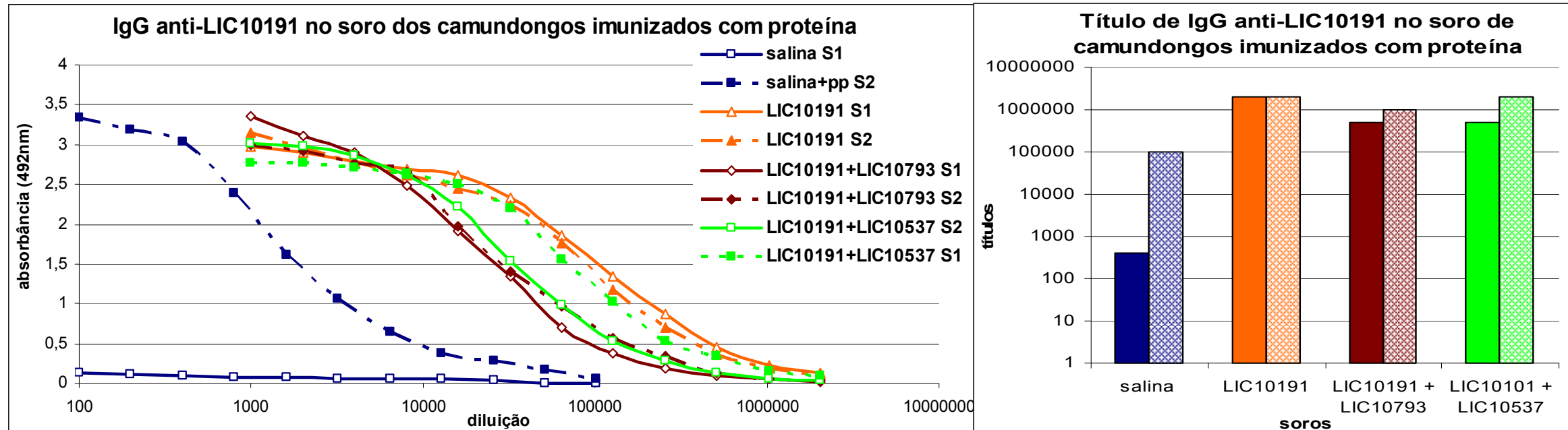

IgG anti-LIC10191 no soro de camundongos imunizados com salmonela
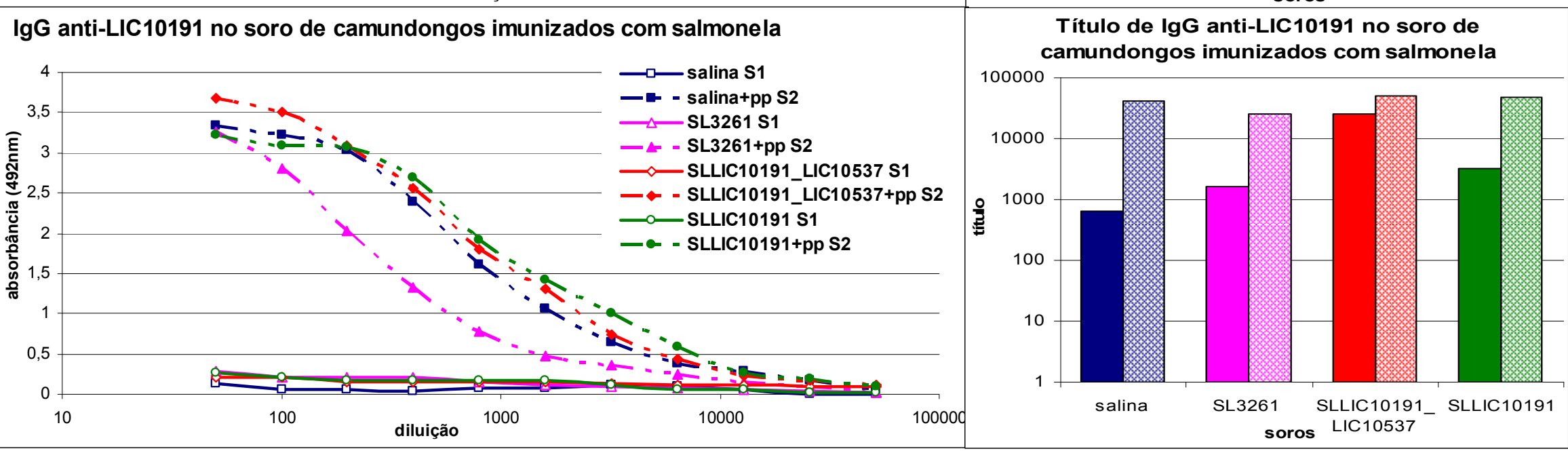

Figura 42 - IgG anti-LIC10191 no soro dos camundongos imunizados com proteínas purificadas e com salmonelas recombinantes SLLIC10191, SLLIC10191_LIC10537. S1 Sangria quinze dias após segunda dose e S2, quinze dias após terceira dose. Todos os grupos receberam $5 \mu$ g de proteína purificada na última imunização. As placas foram sensibilizadas com $500 \mathrm{ng}$ da proteína LIC10191 por poço. A diluição inicial dos soros foi 1:50 ou 1:1000. Nos gráficos de títulos obtidos a partir das curvas de ELISA, as barras sólidas e as barras hachuradas correspondem a S1 e S2, respectivamente. 


\subsubsection{Avaliação do reconhecimento dos antígenos por anticorpos específicos dos soros dos animais imunizados, por western blot}

Os soros dos animais imunizados com SLLIC10191 ou SLLIC10793 foram utilizados para confirmar a expressão in vivo das proteínas. Podemos observar nas Figuras 43A e 43D uma banda tênue de reconhecimento das proteínas LIC10191 e LIC10793 pelo soro dos animais imunizados com duas doses de SLLIC10191 ou SLLIC10793. O reconhecimento das proteínas pelo soro aumenta após a administração de uma dose de proteína purificada (Figuras 43B e 43E).

Todos os animais do grupo SLLIC10191_LIC10793 morreram após a primeira dose, não soubemos determinar se houve o aumento da toxicidade da salmonela quando expressando dois antígenos e não detectamos contaminantes na cultura utilizada na imunização. Para verificar a expressão das duas proteínas in vivo, realizamos um novo ensaio com apenas um grupo de camundongos imunizados com SLLIC10191_LIC10793. Administramos três doses de salmonela carregando o vetor híbrido, com intervalo de 15 dias e fizemos uma sangria após a terceira dose. Na Figura 43C podemos observar que as proteínas purificadas foram reconhecidas pelo soro dos camundongos imunizados com SLLIC10191_LIC10793 confirmando a expressão das proteínas in vivo. 


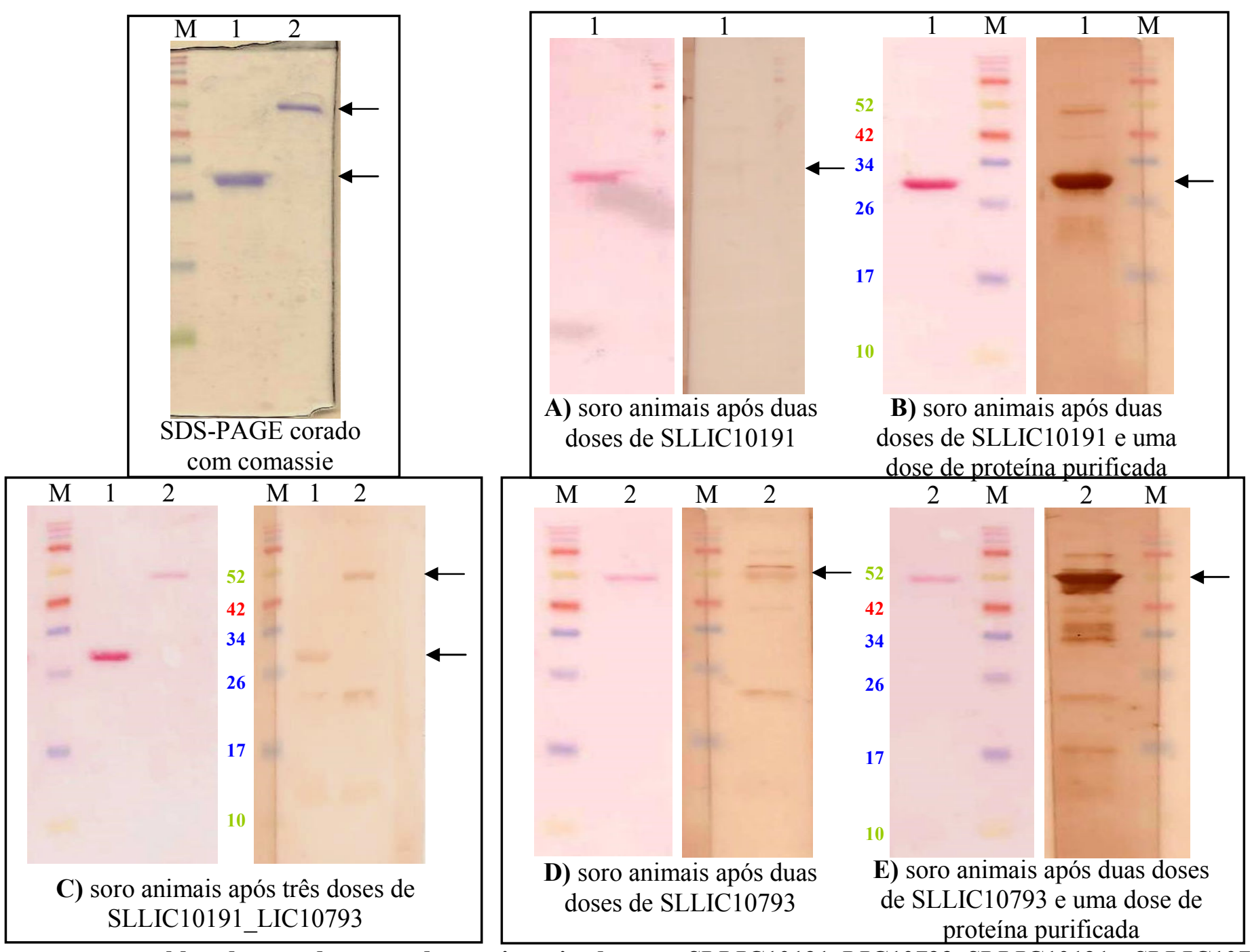

Figura 43 - Análise por western blot, do soro de camundongos imunizados com SLLIC10191_LIC10793, SLLIC10191 e SLLIC10793. Em A), B), D) e E) soro dos animais imunizados com duas doses de salmonela e uma terceira dose de proteína purificada. Em C) soro de animais imunizados com três doses de SLLIC10191_LIC10793. Canaletas: 1- LIC10191 e 2- LIC10793. M- marcador de massa molécula. 


\subsection{Imunização de hamster para avaliar imuno proteção em ensaios de desafio com leptospiras virulentas}

\subsubsection{Primeiro ensaio de imunização de hamsters e desafio com Leptospira interrogans sorovar Pomona}

Realizamos experimento de imunização de hamsters com proteínas recombinantes purificadas ou com salmonelas recombinantes para expressão dos antígenos in vivo. Os animais receberam 3 doses dos imunógenos em intervalos de 15 dias. Os grupos de imunização e doses utilizadas estão descritos na Tabela 8.

Tabela 8 - Grupos de imunização de hamsters e doses administradas via intraperitoneal.

\begin{tabular}{lc}
\hline \multicolumn{1}{c}{ Grupos de imunização / via intraperitoneal } & Dose \\
\hline 1. controle salina & $250 \mu \mathrm{l}$ \\
2. controle vacina comercial Pfizer & Diluição $1: 800 / 250 \mu 1$ \\
3. proteínas LIC10793, LIC12631 e LIC12659 & $5 \mu \mathrm{g}$ de cada proteína/ $250 \mu \mathrm{l}$ \\
4. proteína LIC10191 & $5 \mu \mathrm{g} / 250 \mu 1$ \\
5. controle SL3261 - vazia & $5 \times 10^{7}$ bactérias/ $250 \mu \mathrm{l}$ \\
6. SLLIC10191 & $5 \times 10^{7}$ bactérias/ $250 \mu 1$ \\
\hline
\end{tabular}

Quinze dias após a última imunização os animais foram desafiados com Leptospira interrogans sorovar Pomona virulenta para avaliar a capacidade dos antígenos em induzir imuno proteção.

No protocolo de desafio utilizamos macerado de fígado de hamsters que haviam sido infectados experimentalmente cinco a sete dias antes do dia do desafio. Para calcular a quantidade de bactérias a ser utilizada no desafio considerou-se a contagem das leptospiras em microscópio de campo escuro da diluição $10^{-3}$, do macerado de fígado. A contagem de cinco campos resultou em 58 bactérias. O cálculo do número de bactérias na suspensão de macerado, considerando as diluições e o volume de amostra na lâmina de contagem, foi $5,8 \times 10^{8}$ lept $/ \mathrm{mL}$.

Para ensaio de desafio os animais foram inoculados com $200 \mu \mathrm{l}$ da diluição $10^{-6}$ do macerado de fígado, correspondendo a 116 Leptospira interrogans sorovar Pomona, por animal. Em paralelo, foi feita uma curva de dose com grupos de animais inoculados com as 
diluições $10^{-5}$ a $10^{-11}$. O número de animais sobreviventes ao longo de 21 dias foi registrado Figura 44.

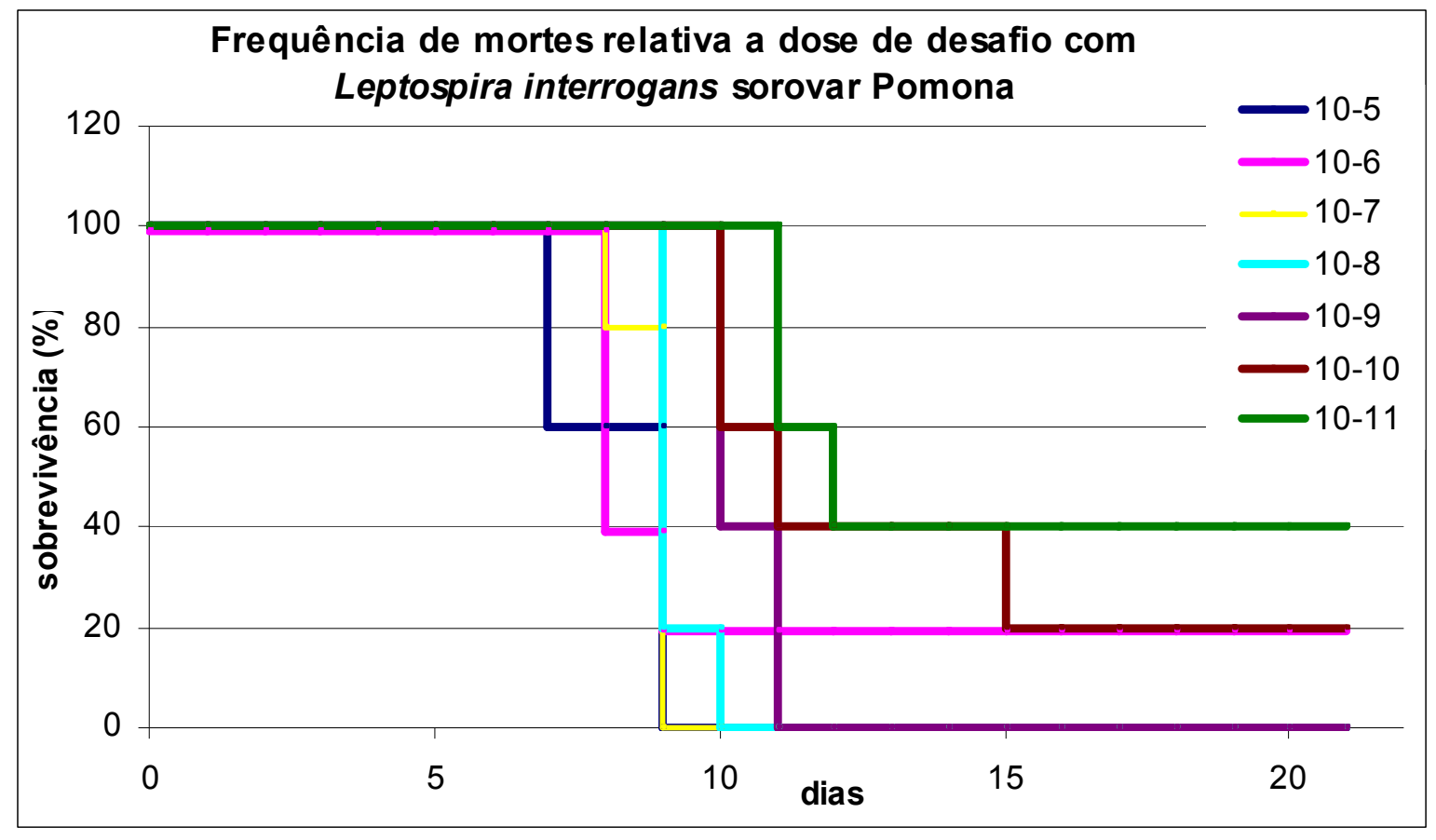

Figura 44 - Curva de freqüência de mortes dos hamsters inoculados com diferentes doses de Leptospira interrogans sorovar Pomona durante 21 dias após o inóculo. As doses estão referidas na figura como diluições do extrato do macerado do baço de um hamster infectado experimentalemente. Os animais foram observados durante 21 dias após o inoculo.

O rim dos animais que sobreviveram foram extraídos para análise da presença de leptospiras. Apenas o animal do grupo da diluição $10^{-6}$ teve resultado positivo no cultivo, enquanto os sobreviventes dos grupos de diluição $10^{-10}$ e $10^{-11}$ tiveram resultado negativo. As curvas apresentadas mostram que a porcentagem de sobrevivência está diretamente relacionada com a dose administrada. Podemos observar certo atraso na frequência de mortes nos grupos que receberam doses menores de leptospiras, mostrando que nesse período de incubação a infecção se agrava antes do desenvolvimento de imunidade.

Neste experimento, segundo a contagem das bactérias em lâmina, os animais foram desafiados com 116 bactérias na diluição $10^{-6}$, porém observamos morte mesmo entre os animais inoculados com diluição $10^{-11}$. Isso indica que na diluição $10^{-11}$ havia ao menos uma bactéria virulenta, e então na diluição $10^{-6}$ deveria ter cerca de $10^{5}$ bactérias, ou seja, 1000 vezes mais bactérias que o calculado. De acordo com as curvas de freqüência de morte, podemos considerar $\mathrm{DL}_{50}$ corresponderia aproximadamente à diluição $10^{-11}$, calculada pelo 
método de Reed e Muench (1938), que utiliza freqüência acumulada de morte e sobrevivência (Anexo A).

A Figura 45 e a Tabela 9 mostram os resultados do ensaio de desafio com os animais imunizados. Observa-se que houve sobrevivência de um animal no grupo controle salina e outro no grupo controle salmonela sem plasmídeo, assim como no grupo imunizado com a proteína LIC10191 purificada e no grupo "pool" de três proteínas, indicando que esses antígenos não induziram efeito imune protetor no desafio com L. interrogans sorovar Pomona. No grupo imunizado com SLLIC10191 obtivemos melhor resultado de proteção, com quatro animais sobreviventes ao final dos 21 dias, e ainda um animal sobrevivente até o vigésimo dia.

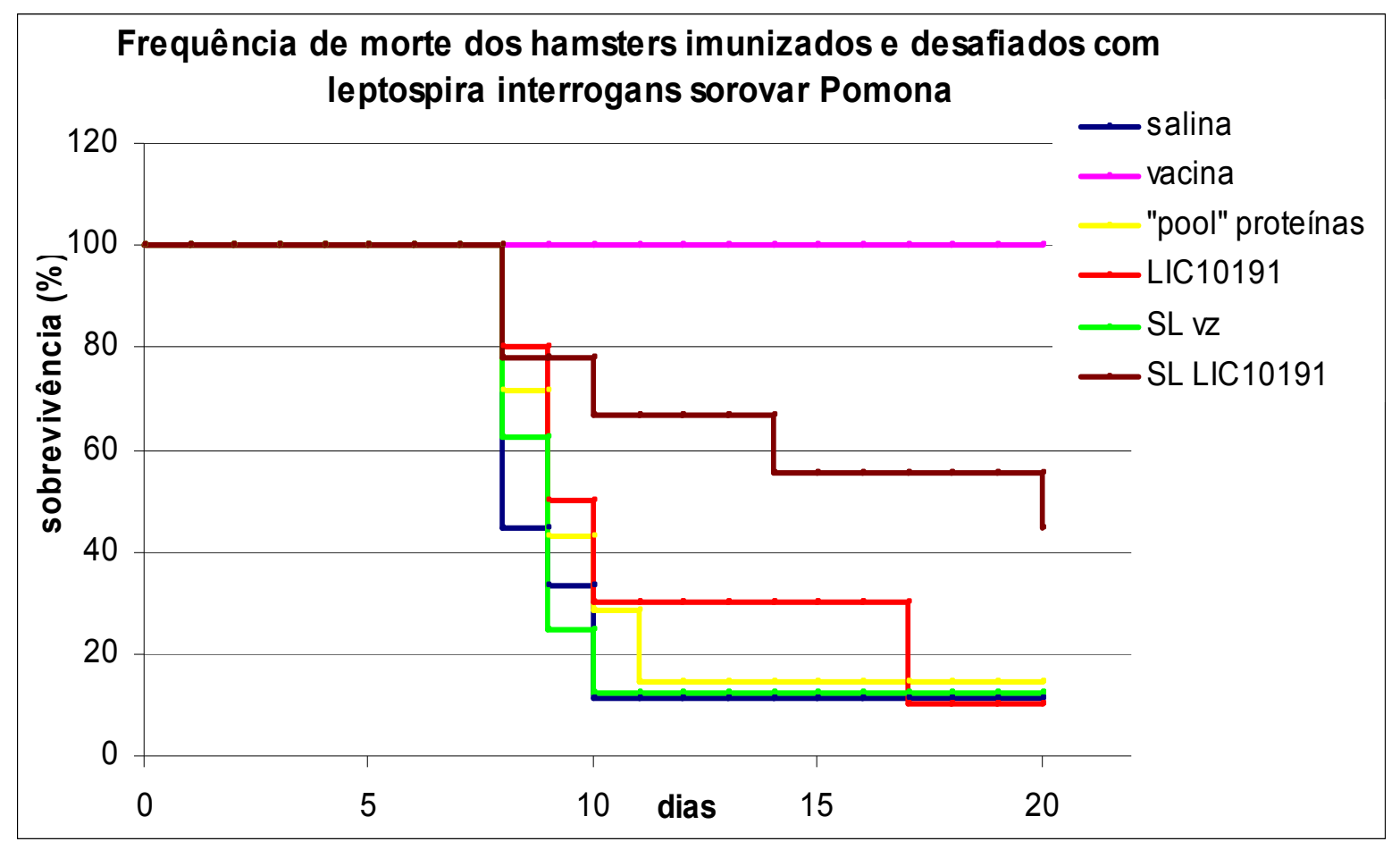

Figura 45 - Frequência de mortes dos hamsters imunizados com proteínas e salmonela recombinantes e desafio com Leptospira interrogans sorovar Pomona. Os animais foram observados durante 21 dias. 
Tabela 9 - Sobrevivência de hamsters imunizados ao desafio com leptospiras. Resultado do teste de isolamento de leptospiras dos rins dos animais sobreviventes.

\begin{tabular}{lcc}
\hline \multicolumn{1}{c}{ Grupos e condições de imunização } & $\begin{array}{c}\text { Sobreviventes }(\%) \\
\text { total de animais }\end{array}$ & $\begin{array}{c}\text { Isolados } \\
\text { positivos }\end{array}$ \\
\hline 1. Controle salina & $1 / 9(11)$ & $0 / 1$ \\
2. Controle vacina comercial veterinária & $10 / 10(100)$ & $0 / 10$ \\
3. Controle SL3261 vazia - 5x107 bactérias & $1 / 8(12,5)$ & $0 / 1$ \\
4. Proteína LIC10191 - 5 $\mu \mathrm{g}$ & $1 / 10(10)$ & $0 / 1$ \\
5. “pool” de 3 proteínas LIC10793, LIC12631 e & $1 / 7(14)$ & $0 / 1$ \\
LIC12659 - 5 $\mu \mathrm{g}$ de cada proteína & $4 / 9(44,5)$ & $1 / 4$ \\
6. SLLIC10191 - 5x107 bactérias & \\
\hline
\end{tabular}

Os dados de sobrevivência sugerem que houve uma interferência interessante da salmonela apresentando o antígeno. Entre os animais que sobreviveram desse grupo, um teve resultado positivo no cultivo de leptospiras do macerado do rim, enquanto os animais sobreviventes dos grupos imunizados com proteínas tiveram resultados de cultivo negativos, Há que se considerar que a aparência dos rins isolados estava alterada em relação a rins normais, e ainda que os animais sobreviventes estavam doentes. Entretanto, o resultado de sobrevivência é significativo.

\subsubsection{Determinação de anticorpos IgG no soro dos animais imunizados, por ELISA.}

Soros dos hamster imunizados foram coletados 8 dias após a ultima imunização (S1) e 22 dias depois do desafio, dos animais sobreviventes (S2). Os soros foram utilizados em ELISAs para dosagem de anticorpos específicos contra as proteínas recombinantes. O soro de cada animal foi preparado individualmente e a concentração de IgG por animal pôde ser comparado antes e após o desafio, no caso dos animais sobreviventes.

Os gráficos de ELISA mostram a presença de IgG anti LIC10191 nos soros dos animais imunizados com a proteína purificada e com as salmonelas recombinantes (Figura 46). Os soros dos animais desse grupo apresentaram títulos relativamente baixos de anticorpos após as imunizações, entretanto esses títulos aumentam após a infecção por leptospira, especialmente nos animais imunizados com SLLIC10191. Note-se que o grupo vacinado não apresentou os anticorpos específicos, sugerindo que o antígeno é exposto quando a leptospira prolifera no hospedeiro. 


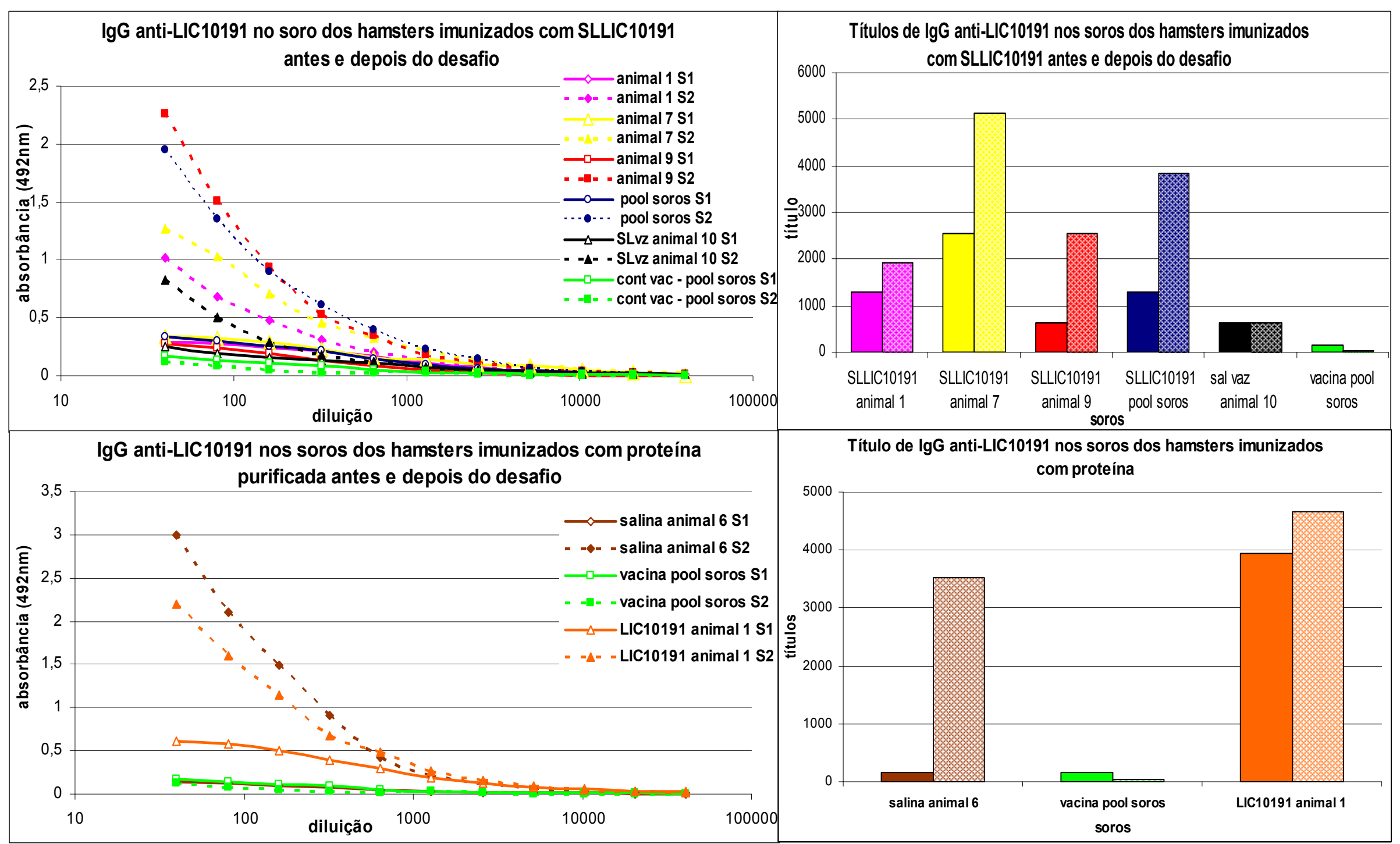

Figura 46 - IgG anti-LIC10191 nos soros dos hamsters imunizados com proteína LIC10191 ou com salmonela SLLIC10191. Os títulos (direita) foram obtidos com os dados das curvas de ELISA (esquerda). S1 - sangria antes do desafio (barras sólidas) e S2 - sangria após o desafio (barras pontilhadas). 
Observando as curvas na Figura 46 nota-se que após infecção com leptospira ocorre aumento de anticorpos reconhecendo a proteína LIC10191 (linhas tracejadas), quer os animais tenham sido previamente imunizados com essa proteína ou não.

Devemos considerar a possibilidade do reconhecimento de proteínas contaminantes de E. coli na preparação de proteína purificada usada na sensibilização das placas. Tais contaminantes poderiam ser proteínas semelhantes às de leptospira e salmonela, as quais também estariam induzindo anticorpos e aumentariam a detecção no ELISA.

O soro dos animais imunizados com a vacina comercial não reconhece a proteína LIC10191, indicando que esta proteína não está presente na preparação vacinal. Entretanto, houve indução de IgG anti-LIC10191 no animal 6 sobrevivente do grupo controle salina/Alhydrogel, indicando que a proteína é apresentada ao sistema imune durante a infecção pela bactéria.

Infecção por leptospira pode levar o animal a um quadro de septissemia que resultaria em aumento de anticorpos contra proteínas de outras bactérias.

Sabemos que os resultados de ELISA podem somar reconhecimento dos soros pelas proteínas contaminantes de E. coli. A especificidade de reconhecimento por anti-LIC10191 será avaliada nos ensaios de western blot.

Estudos indicam que a LIC10191 (Loa22) é essencial para a virulência da bactéria durante a infecção (RISTOW et al., 2007). Bactérias L. interrogans sorovar Lai com o gene de Loa22 deletado foram inoculadas em cobaias e esses animais não mostraram sinais da doença até 21 dias após a injeção.

O soro dos animais imunizados com três doses de SLLIC10191 mostrou baixo reconhecimento pela proteína recombinante por ELISA (Figura 46). Apesar disso, quatro animais, em um grupo de nove, sobreviveram á infecção (44,5\%). Essa sobrevivência é bastante significativa nos nossos ensaios. Além disso, em apenas um animal sobrevivente foi possível isolar leptospiras do macerado do rim, sugerindo que a imunização foi capaz também de impedir a colonização dos tecidos pela bactéria. O baixo título de IgG anti-LIC10191 nos soros dos animais sobreviventes em comparação com os títulos induzidos por imunização com a proteína purificada sugere que outros componentes do sistema imune podem estar relacionados com a proteção.

Para verificar a resposta imune em hamsters, avaliamos, por ELISA, a presença de anticorpos anti-LIC10793 nos soros dos animais imunizados com um "pool" de três proteínas, LIC10793, LIC12631 e LIC12659 (Figura 47). 


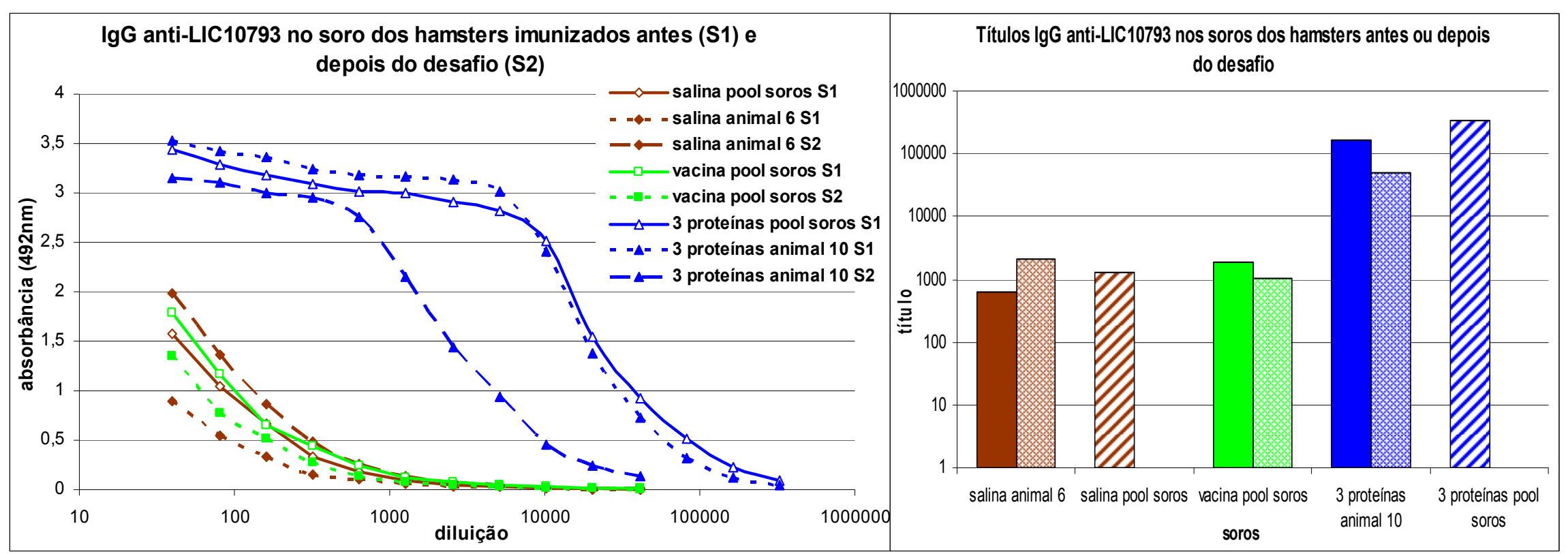

Figura 47 - Anticorpos IgG anti-LIC10793 no soro dos hamsters imunizados com o "pool” de três proteínas LIC10793, LIC12631 e LIC10659. A placa foi sensibilizada com $500 \mathrm{ng}$ da proteína LIC10793 por poço. S1 sangria antes do desafio, sangue coletado 8 dias após a terceira imunização; S2 sangria dos animais que sobreviveram 22 dias após o desafio, animal 6 do grupo salina e animal 10 do grupo "pool" de 3 proteinas, alem do grupo vacinado com todos os animais sobreviventes. B- Títulos de IgG anti-LIC10793 definidos pelo ELISA. 
A proteína LIC10793 mostrou maior imunogenicidade que a LIC10191. Apesar de mais altos títulos, não observamos proteção, sendo que apenas um animal, entre sete, sobreviveu á infecção no grupo imunizado com o "pool” de proteínas.

Segundo Neves et al. (2007), a proteína LIC10793 é conservada entre muitos sorovares de L. interrogans (Copenhageni, Icterohaemorrageae, Canicola, Hardjo e Pomona) e poderia ser utilizada em testes de diagnóstico para humanos e animais.

Note-se que após infecção por leptospira o título de anticorpo anti-LIC10191 aumentou nos animais sobreviventes, enquanto diminuiu o anti-LIC10793 no grupo imunizado com a proteína LIC10793. Certamente esse dado é tomado com restrições uma vez que se refere a um único animal sobrevivente. Qualquer conclusão em relação a essas observações deve considerar que há um balanço de produção e consumo de anticorpos durante infecção, e que a cinética de desaparecimento dos anticorpos após retirada do estímulo pode ser uma resposta complexa.

As curvas de dose de leptospira nos ensaios de desafio são sempre feitas em paralelo com o próprio ensaio, usando a mesma preparação de bactérias. A experiência do grupo do Prof. Silvio Vasconcellos permite adequar a dose no desafio com o sorovar Pomona, porém o ensaio apresenta variabilidade intrínseca, indicada por morte de animais em grupo com menor dose e sobrevivência de animais em grupos com maior dose. Portanto, os ensaios de proteção devem sempre ser repetidos para confirmação.

A despeito da necessidade de confirmação por repetição dos ensaios de desafio, os ensaios com salmonelas com dados de colegas do laboratório tem se mostrado bastante interessantes, uma vez que mesmo apresentando baixos títulos de anticorpos, determinam proteção ainda que parcial.

\subsubsection{Avaliacão do reconhecimento dos antígenos por anticorpos específicos dos soros}

\section{dos animais imunizados por western blot}

Os soros dos hamsters imunizados foram usados em ensaios de Western Blot para verificar o reconhecimento dos anticorpos sobre as proteínas LIC10191 e LIC10793. A Figura 48A mostra o perfil das proteínas em SDS-PAGE e, depois da transferência para membranas, o perfil de reconhecimento das proteínas por diversos soros. Como controles foram usados os soros de animais que receberam somente salina/Alhydrogel ou controle salmonela. Também foi usado soro dos animais vacinados com a vacina comercial, soro dos animais imunizados 
com as proteínas purificadas LIC10191 e LIC10793 e com as salmonelas recombinantes apresentando esses mesmos antígenos. Por fim também foram usados soros dos animais desses mesmos grupos de imunização que sobreviveram ao desafio. Todos os soros foram introduzidos na diluição 1:1000. O segundo anticorpo utilizado foi anti-IgG de hamster conjugado com peroxidase feito em cabra (KPL). A Tabela 10 resume os resultados obtidos nos ensaios de wetern blot.

Tabela 10 - Intensidade relativa do reconhecimento de LIC10191 e LIC10793 por IgG específicos no soro dos animais imunizados antes e depois do desafio. Avaliação das Figuras 48 e 49.

\begin{tabular}{|c|c|c|c|c|}
\hline \multirow{3}{*}{ Grupos e condições de imunização } & \multicolumn{4}{|c|}{ Reconhecimento de anticorpos IgG } \\
\hline & \multicolumn{2}{|c|}{ LIC10191 } & \multicolumn{2}{|c|}{ LIC10793 } \\
\hline & $\begin{array}{l}\text { Antes do } \\
\text { desafio }\end{array}$ & $\begin{array}{l}\text { Após o } \\
\text { desafio }\end{array}$ & $\begin{array}{c}\text { Antes do } \\
\text { desafio }\end{array}$ & $\begin{array}{l}\text { Após o } \\
\text { desafio }\end{array}$ \\
\hline 1. Controle salina & - & ND & - & ND \\
\hline 2. Controle vacina comercial veterinária & - & + & - & - \\
\hline 3. Controle SL3261 vazia - $5 \times 10^{7}$ bactérias & - & - & - & + \\
\hline 4. Proteína LIC10191 - $5 \mu \mathrm{g}$ & + & ND & $\mathrm{X}$ & $\mathrm{X}$ \\
\hline $\begin{array}{l}\text { 5. “pool” de } 3 \text { proteínas LIC10793, LIC12631 } \\
\text { e LIC12659 - } 5 \mu \text { g de cada proteína }\end{array}$ & $\mathrm{X}$ & $\mathrm{X}$ & +++ & +++ \\
\hline 6. SLLIC10191 - 5×107 bactérias & + & ++ & $\mathrm{X}$ & $\mathrm{X}$ \\
\hline
\end{tabular}

+: reconheceu/ -: não reconheceu/ ND: não determinado/ X: não realizado 


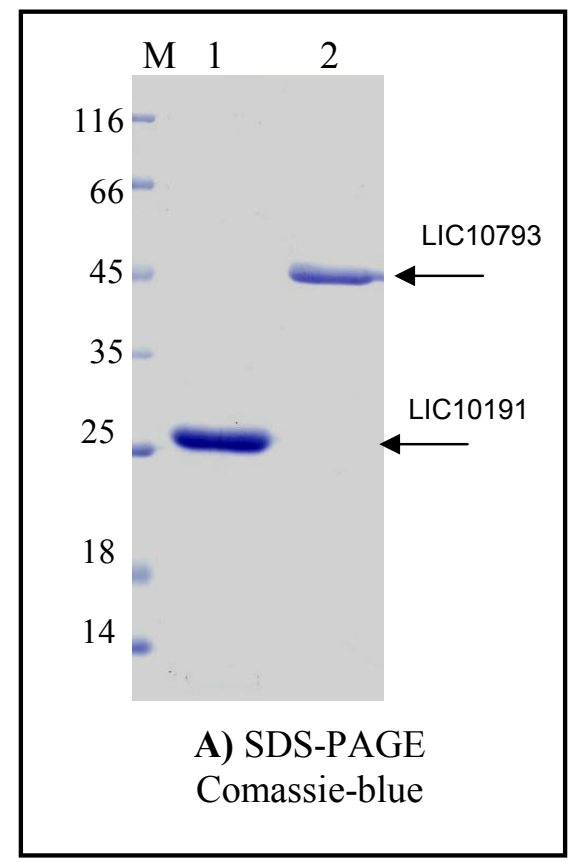

A) SDS-PAGE

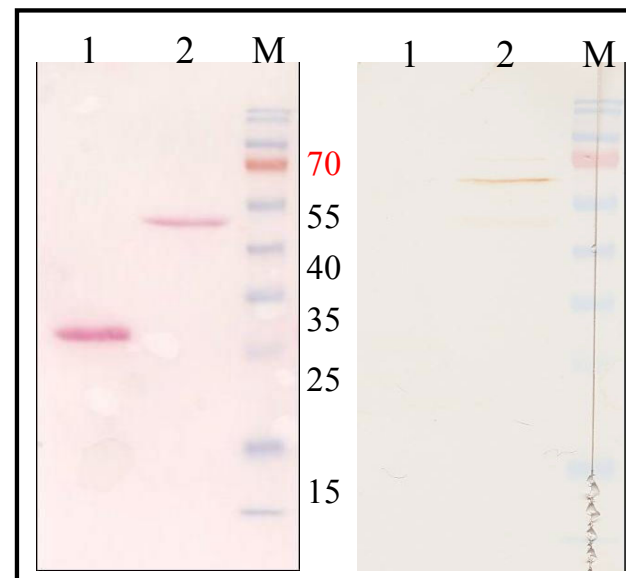

B) Soro do grupo controle salina/ Alhvdrogel (antes do desafio)

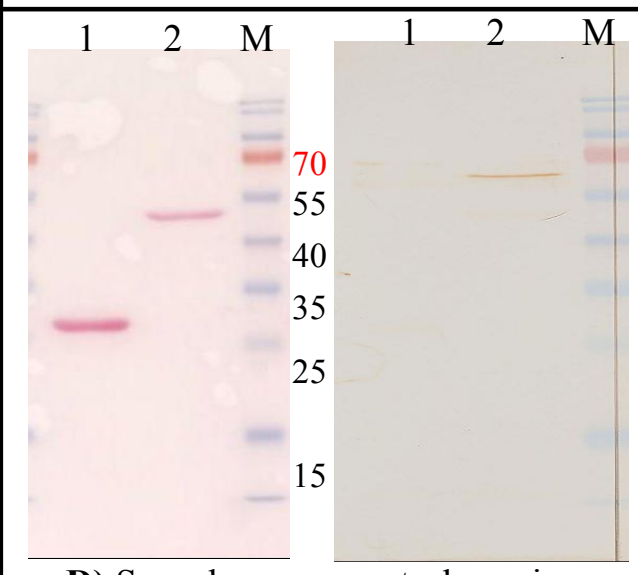

D) Soro do grupo controle vacina comercial (antes do desafio)

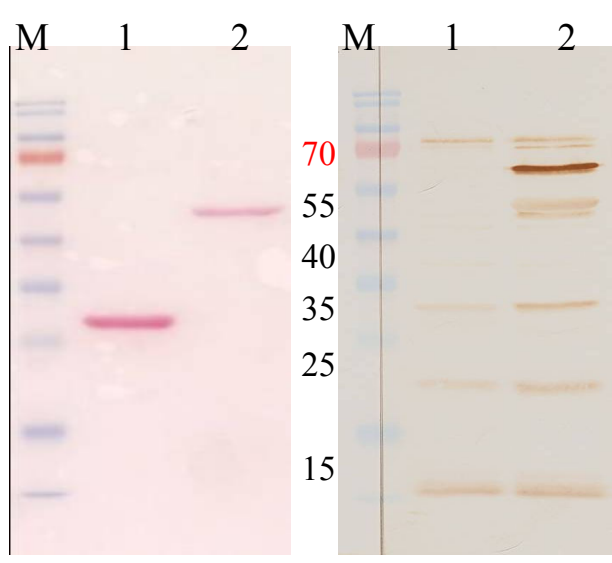

C) Soro do grupo controle salmonela vazia (antes do desafio)

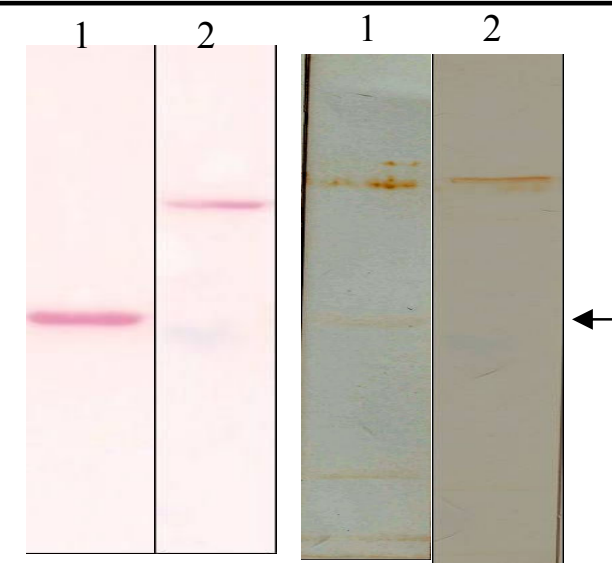

E) Soro do grupo controle vacina comercial (depois do desafio)

Figura 48 - Reconhecimento das proteínas LIC10191 e LIC10793 por anticorpos dos soros de animais dos grupos controle antes e após o desafio com Leptospira interrogans sorovar Pomona. Amostras das proteínas purificadas, canaletas: 1- LIC10191 e 2- LIC10793, foram separadas por SDS-PAGE. Após transferência das proteinas as membranas foram coradas com Ponceau e depois expostas aos soros indicados em cada quadro. M- marcador de massa molecular. 

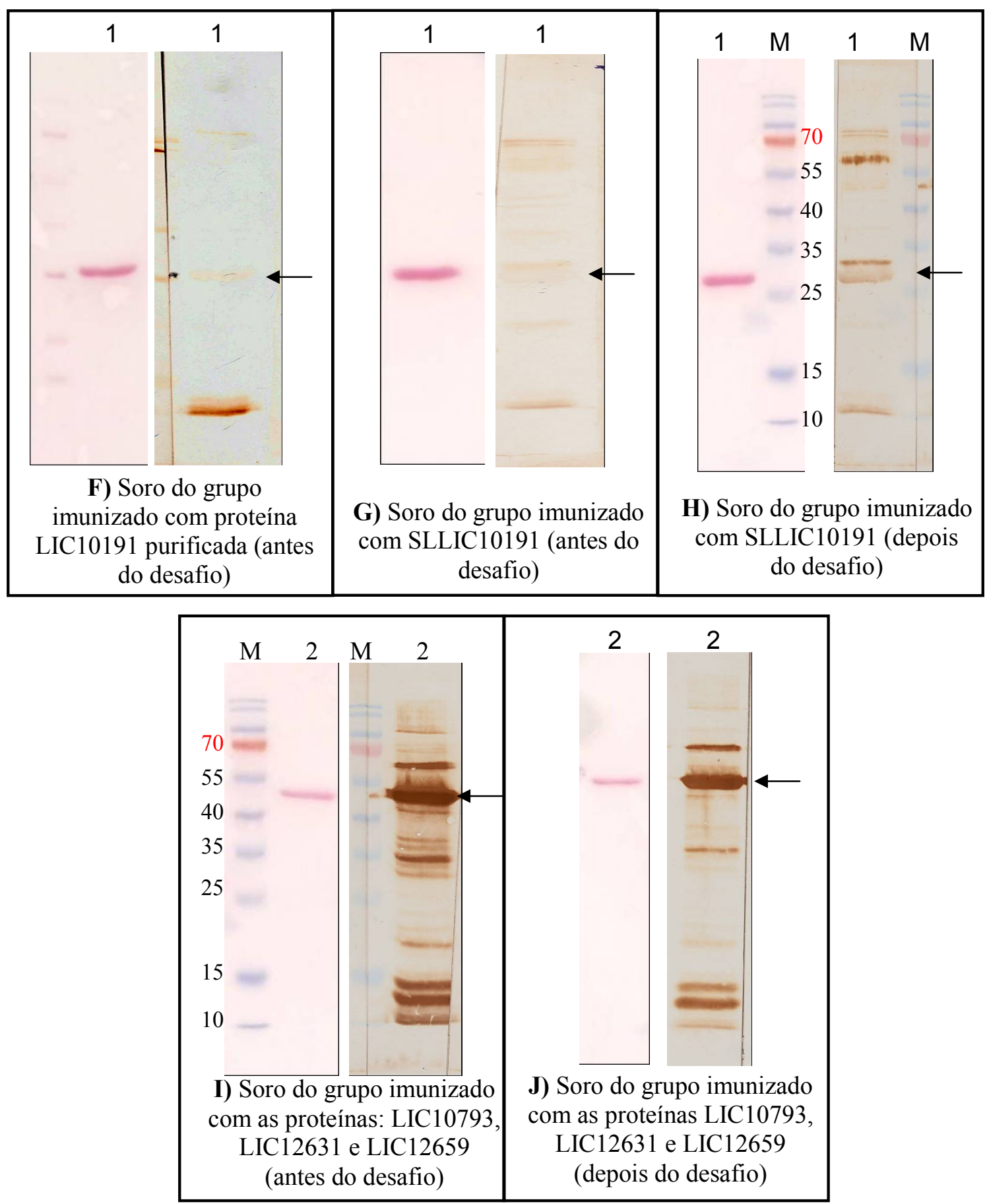

Figura 49 - Reconhecimento das proteínas recombinantes LIC10191 e LIC10793 por anticorpos dos soros de animais imunizados. Amostras com $5 \mu \mathrm{g}$ das proteínas purificadas canaletas: 1 - LIC10191 e 2 - LIC10793, foram separadas por SDS-PAGE. Mmarcador de massa molecular. Após transferência das proteinas as membranas foram coradas com Ponceau e então expostas aos soros indicados em cada quadro. 
A Figura 48 mostra que todos os soros reconhecem uma banda de proteína contaminante de $\sim 65 \mathrm{kDa}$ nas canaletas com a proteína LIC10793 purificada. Mostra também que o soro dos animais imunizados com salmonelas vazias reconhece várias proteínas contaminantes tanto na preparação de LIC10191 como na de LIC10793, provavelmente anticorpos induzidos contra proteínas de salmonela homologas a proteínas de E. coli, contaminantes das preparações.

É possível notar uma banda tênue de reconhecimento do soro do grupo de animais que foram imunizados com a vacina comercial pela proteína LIC10191 (Figura 48E), além de algumas proteínas contaminantes.

Podemos observar a proteína LIC10191 sendo reconhecida pelo soro dos animais imunizados com a proteína purificada (Figura 49F). O reconhecimento é tênue comparado com a banda reconhecida pelo soro dos animais imunizados com a SLLIC10191 (Figura 49G), porém, esse resultado corrobora os dados obtidos no ELISA, nos quais observamos baixos títulos de IgG anti-LIC10191 no soro dos animais imunizados com SLLIC10191. Ainda assim o conteúdo de IgG anti-LIC10191 são mais elevados quando comparados aos títulos obtidos no soro dos animais imunizados com proteína purificada. Esse dado sugere que a dose de proteína purificada administrada nos hamsters deve ser maior do que a dose administrada nos camundongos.

Na Figura 49G, a banda tênue de reconhecimento da proteína LIC10191 pelo soro dos animais imunizados com SLLIC10191 confirma a expressão do antígeno in vivo e sua apresentação por salmonelas ao sistema imune dos hamsters. Bastante interessante também é o fato de ocorrer aumento no reconhecimento da proteína LIC10191 no soro de animais sobreviventes do grupo imunizado com SLLIC10191 (Figura 49H), confirmando o resultado do ELISA e a especificidade de indução de anticorpos anti-LIC10191 durante a infecção por leptospiras.

Nas Figuras 49I e 49J observam-se muitas bandas de reconhecimento de proteínas contaminantes, além do reconhecimento da LIC10793 pelo soro de animais imunizados com o "pool" de 3 proteínas. Nesses mesmos quadros pode-se observar o reconhecimento da proteína LIC10793, tanto pelo soro coletado antes do desafio quanto no soro dos animais sobreviventes ao desafio. Nesse caso, diferente do caso da LIC10191, não se nota aumento da intensidade da banda após o desafio, mas diminuição. A intensidade da banda indica que a LIC10793 é uma proteína mais imunogênica do que a LIC10191. Esses resultados estão de acordo com os resultados dos ELISAs. 


\subsubsection{Estudos para desafio com Leptospira interrogans sorovar Copenhageni}

Uma etapa importante do desenvolvimento deste projeto foi o estabelecimento de uma linhagem virulenta de leptospira do sorovar Copenhageni. Esse sorovar é bastante freqüente em infecções em humanos e cães, sendo o sorovar cujo genoma foi seqüenciado com participação do grupo do Butantan e do qual os antígenos em estudo foram derivados. O grupo colaborador do Dr. Silvio Vasconcellos possui muita experiência com outros sorovares, em especial o Pomona e mais recentemente tem estudado o sorovar Copenhageni. Nas tentativas de estabelecimento de uma linhagem Copenhageni virulenta verificou-se que esta apresentava comportamento bastante diferente da Pomona. Um aspecto importante é a dificuldade de contagem das bactérias a partir de macerado de fígado do animal infectado experimentalmente. De fato as L. interrogans Copenhageni são diminutas no isolamento e não é possível contá-las. Por isso há sempre necessidade de cultivo por ao menos uma passagem.

Um segundo aspecto importante observado com bactérias do sorovar Copenhageni é a rápida perda de virulência em cultura, sendo que duas ou três passagens podem inviabilizar os ensaios de desafio.

Desta forma, ensaios de desafio com leptospiras apresentam dificuldades para determinação da $\mathrm{DL}_{50}$ devido à imprecisão da contagem de bactéria e da rápida alteração das características de virulência. Entretato, e outros ensaios de desafio do laboratório o cultivo das bactérias por uma passagem levou a perda de virulência, enquanto em outro ensaio, quatro passagens não foram determinantes da perda de virulência, ilustrando a grande variabilidade dos parametros desse ensaio.

Os ensaios de desafio com leptospiras representam uma dificuldade constante e muitas investigações tem sido citadas na literatura (SILVA et al., 2008) e reportadas entre os pesquisadores do Butantan tentando otimizar a grande variação na resposta. Apesar de variações serem uma característica intrinseca dos sistemas biológicos, no caso dos desafios com leptospiras muitos parâmetros são de difícil controle. Por exemplo, o número de bactérias não é um parametro absoluto, pois geralmente não reflete a virulência da cultura; o decaimento da virulência das leptospiras em cultivo é conhecido e não é linear.

Descrevemos a seguir alguns ensaios realizados com o objetivo de conhecer melhor os parâmetros gerais para nossos ensaios de desafio. 


\subsubsection{Freqüência de morte dos hamsters infectados com diferentes doses de Leptospira}

interrogans sorovar Copenhageni com duas passagens em cultura

Para uma análise prévia da dose de Leptospira interrogans sorovar Copenhageni nos desafios fizemos um ensaio infectando animais com diferentes doses de bactérias após duas passagens em cultura em meio EMJH. O cultivo foi preparado como descrito no item 3.15 de Materiais e Métodos. A cultura de primeira passagem foi repicada diluindo a amostra 10 vezes em meio EMJH, sendo essa cultura mantida por mais sete dias a $30{ }^{\circ} \mathrm{C}$.

Uma alíquota da cultura de segunda passagem foi usada para contagem ao microscópio resultando em $1,9 \times 10^{7}$ lept $/ \mathrm{mL}$ no cultivo. Também foi feita a contagem de bactérias em câmara de Petroff-Haussen, resultando em 9x10 lept/mL. Em outros ensaios reproduzimos os dados que indicam que ocorre um erro sistematico de cerca de $4 \mathrm{X}$ nessas duas formas de contagem.

Para o teste preliminar de dose letal inoculamos 3 grupos de 5 hamsters com as diluições 1:4, 1:40 e 1:400 da cultura de leptospiras de segunda passagem em $200 \mu$ de salina e os animais foram observados por 34 dias. As curvas de freqüência de morte estão apresentadas na Figura 50.

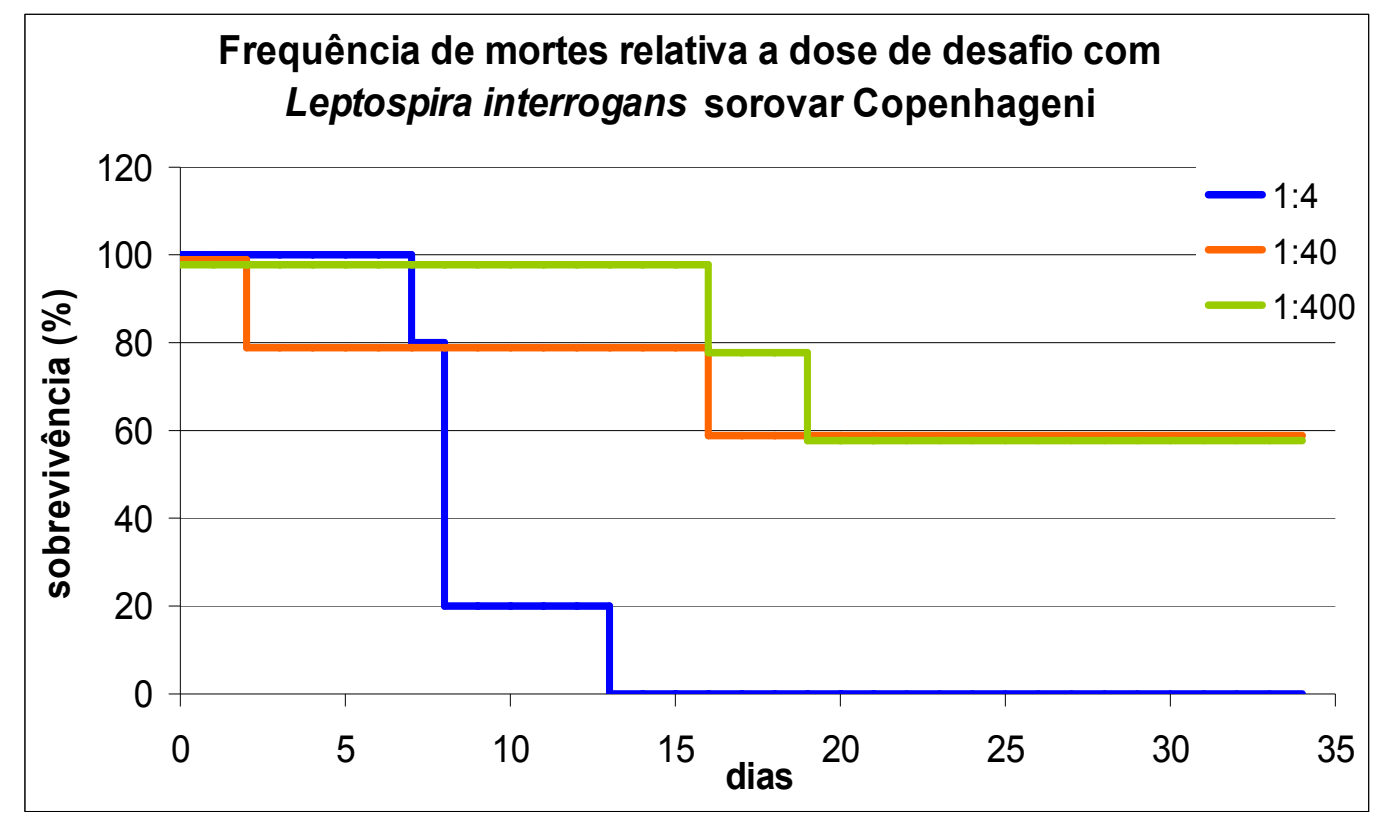

Figura 50 - Frequência de morte dos animais inoculados com diferentes doses de Leptospira interrogans sorovar Copenhageni de segunda passagem. Os animais foram inoculados com $200 \mu \mathrm{l}$ das diluições 1:4, 1:40 e 1:400 de uma cultura de segunda passagem e observados por 34 dias. 
Nesse ensaio pudemos observar que houve um atraso nas mortes nos grupos infectados com menores doses de leptospiras e que sobreviveram $60 \%$ dos animais nesses grupos de maior diluição.

O número de bactérias injetadas nos animais nesse teste de dose segundo as contagens em lâmina e em câmara de Petroff-Haussen e a sobrevivência dos animais esta registrada na Tabela 11.

Tabela 11 - Dose de leptospiras no teste preliminar de desafio segundo as contagens em lâmina ou câmara de Petroff-Hausser e sobrevivência dos animais por 21 dias após a infecção

\begin{tabular}{cccccc}
\hline $\begin{array}{l}\text { Grupo de } \\
\text { desafio }\end{array}$ & $\begin{array}{c}\text { Diluição } \\
\text { da cultura }\end{array}$ & $\begin{array}{c}\text { Número de bactérias por } \\
\text { animal }\end{array}$ & $\begin{array}{c}\text { Contagem em } \\
\text { lâmina }\end{array}$ & $\begin{array}{c}\text { Contagem em } \\
\text { câmara }\end{array}$ & $\begin{array}{c}\text { Total de animais } \\
\text { Isolamento } \\
\text { de leptospira } \\
\text { dos rins }\end{array}$ \\
\hline 1 & $1: 4$ & $5 \times 10^{6}$ & $2,25 \times 10^{7}$ & $0 / 5(0)$ & - \\
2 & $1: 40$ & $5 \times 10^{5}$ & $2,25 \times 10^{6}$ & $3 / 5(60)$ & $1 / 3$ \\
3 & $1: 400$ & $5 \times 10^{4}$ & $2,25 \times 10^{5}$ & $3 / 5(60)$ & $3 / 3$ \\
\hline
\end{tabular}

A sobrevivência de $60 \%$ dos animais inoculados com as doses indicadas de leptospira em comparação com ensaios prévios do laboratório, quando doses mesmo 1000 vezes menores teriam matado todos os animais, indicou que as passagens em cultura diminuem rapidamente a virulência da bactéria. Alguns pesquisadores associam a perda de virulência à presença de soro de coelho no meio de cultivo, mesmo sendo o soro inativado. Muitos protocolos em substituído o soro por albumina bovina, ainda assim os lotes de albumina precisam ser testados, sendo também suspeitos de causar a perda de virulência da leptospira.

\subsubsection{Estudo da variação de susceptibilidade de hamsters machos ou fêmeas e a interferência do meio de cultura na infeccão por Leptospira interrogans sorovar Copenhageni}

O grande número de sobreviventes após a infecção de animais com leptospiras com duas passagens em cultura indicou que houve diminuição da virulência da bactéria. Realizamos um teste de dose com Leptospira interrogans sorovar Copenhageni da linhagem L1-130 com apenas uma passagem em cultura. As bactérias, coletadas de um animal foram crescidas em meio semi-sólido Fletcher durante 25 dias. Após esse período, $500 \mu 1$ dessa 
cultura foram injetados em dois animais. Os animais ficaram sob observação e foram sacrificados 5 dias após a inoculação. Os fígados dos animais foram macerados em salina e diluído em meio de cultura liquido EMJH. Após 14 dias de cultivo a $30^{\circ} \mathrm{C}$ as bactérias foram contadas em microscópio.

A contagem em lâmina resultou $1,7 \times 10^{7}$ bactérias/ml e em câmara de Petroff-Hausser $1,1 \times 10^{8}$ bactérias/ml. Neste ensaio comparamos a diferenças de sensibilidade entre machos e fêmeas à infecção e testamos possível contribuição da toxicidade do meio de cultura condicionado, ou seja, o meio no qual as bactérias haviam crescido, centrifugado e filtrado. Trabalhamos com quatro grupos de cinco animais de 51 dias de idade, dois grupos de fêmeas e dois grupos de machos. Injetamos $50 \mu 1$ da cultura de leptospira por animal, $8,5 \times 10^{5}$ ou $5,5 \times 10^{6}$ leptospiras pela contagem em lâmina ou em câmara de Petroff-Hausser respectivamente, diluído em $450 \mu \mathrm{l}$ de meio de cultura fresco ou condicionado. Na Figura 51 podemos ver o gráfico de freqüência das mortes nos grupos durante 12 dias.

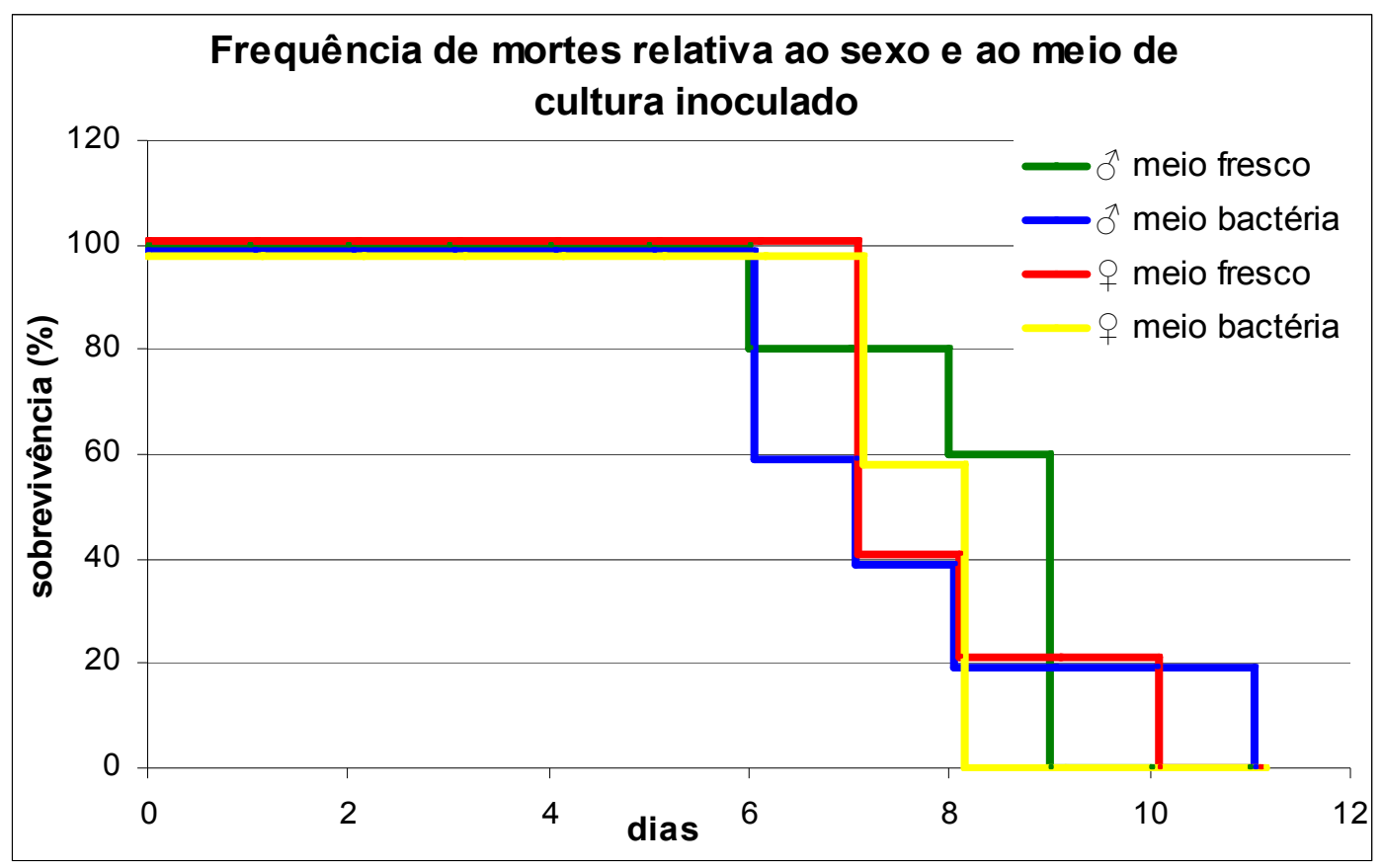

Figura 51 - Frequência de morte dos animais inoculados com Leptospira interrogans sorovar Copenhageni de primeira passagem. Os animais foram inoculados com $50 \mu \mathrm{lde}$ uma cultura de leptospira de primeira passagem diluídos em meio fresco ou meio no qual a bactéria cresceu.

O resultado do ensaio não permitiu inferir diferenças de susceptibilidade dos animais machos ou fêmeas à infecção e também não observamos interferências do meio de cultura fresco ou condicionado na freqüência de mortes dos animais. A dose de L. interrogans 
sorovar Copenhageni administrada nos animais, $50 \mu 1$ de uma cultura de primeira passagem ( $\sim 10^{6}$ bactérias) foi adequada matando todos os animais em até 11 dias.

Considerando os resultados dos dois últimos ensaios, para garantir um desafio na faixa de morte dos animais, optamos por usar um cultivo de leptospira de primeira passagem.

\subsubsection{Segundo ensaio de imunização e desafio em hamsters com Leptospira interrogans sorovar Copenhageni}

Os resultados dos ensaios de imunização em camundongos com as salmonelas recombinantes mostraram que as proteínas foram expressas in vivo. Também um ensaio preliminar do laboratório e o nosso primeiro ensaio de imunização e desafio mostraram que os Hamsters podiam receber as salmonelas atenuadas recombinantes e não apresentavam sintomas de toxicidade. Com isso, desenhamos um novo ensaio de imunização e desafio de hamsters. Neste segundo ensaio utilizamos salmonelas recombinantes carregando um plasmídeo híbrido ou apresentando apenas um antígeno, além das imunizações com as proteínas purificadas. Utilizamos 12 grupos de 10 hamsters (Mesocricetus auratus) machos recém desmamados de aproximadamente $60 \mathrm{~g}$ marcados individualmente, administramos 3 doses de imunógenos por via intraperitoneal em intervalo de 15 dias. Os títulos de IgG antiLIC10191 medidos no soro dos hamsters no primeiro ensaio foram baixos, a despeito da alta capacidade imunogênica da proteína verificada nos camundongos. Por isso aumentamos a dose de proteína na imunização dos hamsters. Neste ensaio, administramos $25 \mu \mathrm{g}$ de cada proteína ou $3 \times 10^{7}$ salmonelas recombinantes por animal. Na terceira dose utilizamos $5 \times 10^{7}$ salmonelas.

Os grupos de imunização e doses estão descritos na Tabela 12. Foram realizadas sangrias individuais três dias antes de cada dose e antes do desafio, para traçarmos uma possível correlação entre a sobrevivência do animal ao desafio com os títulos de anticorpos gerados na imunização. Utilizamos três controles negativo, um grupo não recebeu nada, em outro administramos salina/Alhydrogel e outro salmonela vazia (SL3261), além de um controle positivo, imunizado com a vacina comercial. $\mathrm{O}$ desafio neste ensaio foi realizado com a Leptospira interrogans sorovar Copenhageni. 
Tabela 12 - Grupos de imunização de hamsters e doses administradas via intraperitoneal.

\begin{tabular}{|c|c|c|}
\hline Grupo de imunização & $1^{\circ}$ e $2^{\circ}$ dose & $3^{\circ}$ dose \\
\hline 1. controle nada & - & - \\
\hline 2. controle salina & $250 \mu 1$ & $250 \mu 1$ \\
\hline 3. controle vacina comercial - Pfizer & Diluição 1:800/ $200 \mu 1$ & Diluição 1:800/ $200 \mu 1$ \\
\hline 4. proteína LIC10191 & $25 \mu \mathrm{g} / 250 \mu \mathrm{l}$ & $25 \mu \mathrm{g} / 250 \mu \mathrm{l}$ \\
\hline 5. proteína LIC10793 & $25 \mu \mathrm{g} / 250 \mu \mathrm{l}$ & $25 \mu \mathrm{g} / 250 \mu \mathrm{l}$ \\
\hline \multirow{2}{*}{ 6. proteínas LIC10191 e LIC10793 } & $25 \mu \mathrm{g}$ de cada proteína/ & $25 \mu \mathrm{g}$ de cada proteína/ \\
\hline & $250 \mu \mathrm{l}$ & $250 \mu 1$ \\
\hline 7. proteína Lip32 & $25 \mu \mathrm{g} / 250 \mu \mathrm{l}$ & $25 \mu \mathrm{g} / 250 \mu \mathrm{l}$ \\
\hline 8. controle SL3261 & $3 \times 10^{7} \mathrm{CFU} / 250 \mu \mathrm{l}$ & $5 \times 10^{7} \mathrm{CFU} / 250 \mu \mathrm{l}$ \\
\hline 9. SLLIC10191 & $3 \times 10^{7} \mathrm{CFU} / 250 \mu \mathrm{l}$ & $5 \times 10^{7} \mathrm{CFU} / 250 \mu \mathrm{l}$ \\
\hline 10. SLLIC10793 & $3 \times 10^{7} \mathrm{CFU} / 250 \mu \mathrm{l}$ & $5 \times 10^{7} \mathrm{CFU} / 250 \mu \mathrm{l}$ \\
\hline 11. SLLIC10191_LIC10793 & $3 \times 10^{7} \mathrm{CFU} / 250 \mu \mathrm{l}$ & $5 \times 10^{7} \mathrm{CFU} / 250 \mu \mathrm{l}$ \\
\hline 12. SLLip32 & $3 \times 10^{7} \mathrm{CFU} / 250 \mu \mathrm{l}$ & $5 \times 10^{7} \mathrm{CFU} / 250 \mu \mathrm{l}$ \\
\hline
\end{tabular}

Em paralelo ao desafio dos animais imunizados elaboramos a curva de dose com quatro grupos de animais não imunizados. A contagem de leptospiras na cultura de primeira passagem resultou em $1,25 \times 10^{7}$ ou $7,5 \times 10^{7}$ bactérias $/ \mathrm{mL}$ pela contagem em lâmina ou em câmara de Petroff-Hausser respectivamente. Os animais foram inoculados com $200 \mu \mathrm{L}$ da cultura sem diluição para o desafio. A curva de dose foi feita com 2 doses (400 $\mu \mathrm{L}), 1$ dose, diluição 1:10 e diluição 1:100 a partir da cultura sem diluição.

A Figura 52 mostra as freqüências de morte da curva de dose e a Tabela 13 resume os resultados de contagem das bactérias, as doses usadas na curva de desafio e a freqüência de sobrevivência observada em 21 dias. Analisando os resultados de sobrevivência da curva de dose verificamos que a cultura pura de primeira passagem de L. interrogans sorovar Copenhageni estava bastante virulenta, matando os animais entre cinco e sete dias. 


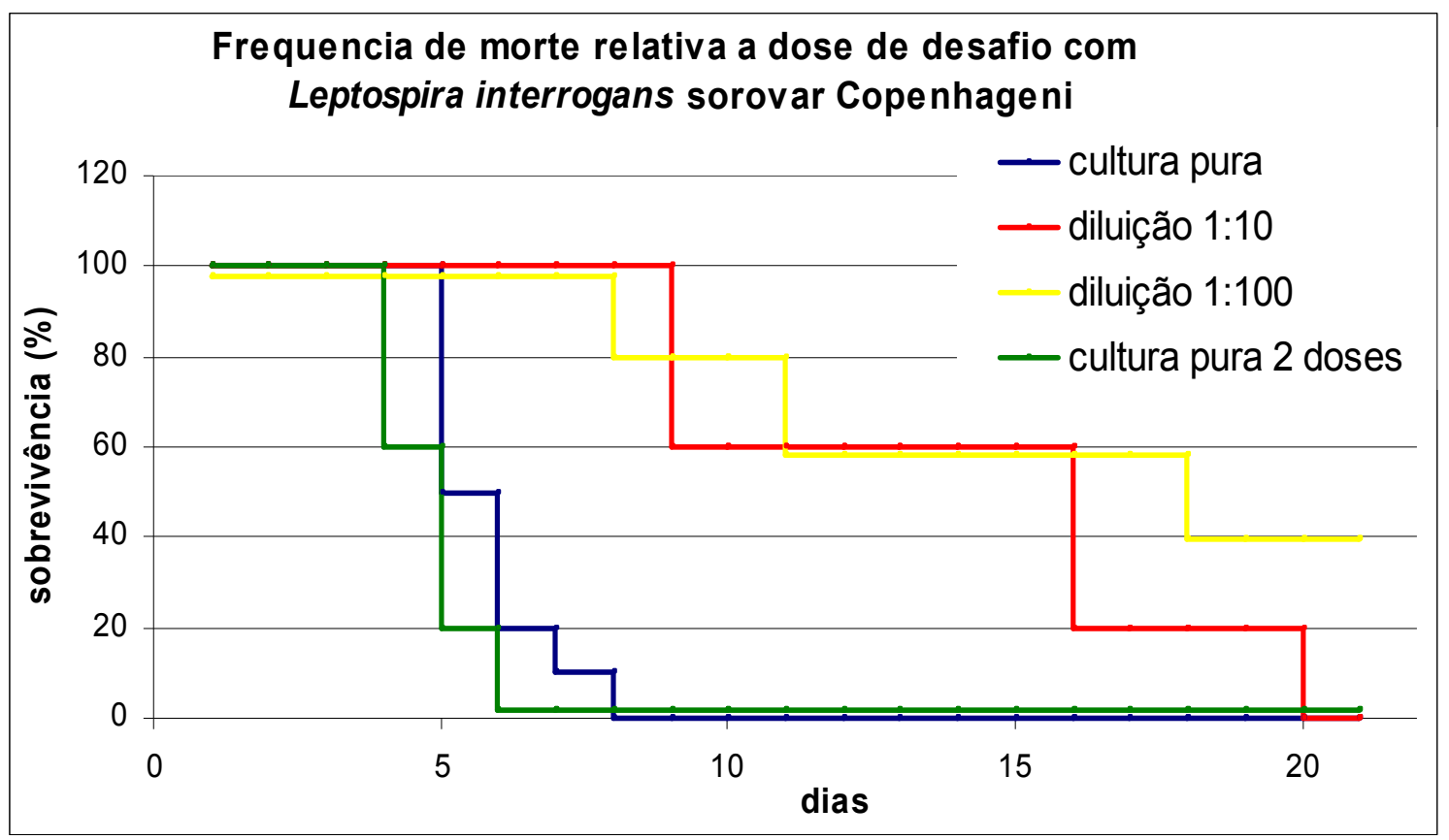

Figura 52 - Frequência de mortes dos animais infectados com diferentes doses de Leptospira interrogans sorovar Copenhageni de primeira passagem. Utilizamos uma cultura de primeira passagem nas diluições indicadas na figura. Os animais foram observados por 21 dias.

Tabela 13 - Contagem das leptospiras em lâmina e câmara de Petroff-Hausser, doses do desafio e sobrevivencia dos animais

\begin{tabular}{|c|c|c|c|c|c|}
\hline \multirow{2}{*}{$\begin{array}{c}\text { Grupo de } \\
\text { desafio }\end{array}$} & \multirow{2}{*}{$\begin{array}{l}\text { Vol. equivalente } \\
\text { de cultura } \\
\text { (diluição) }\end{array}$} & \multicolumn{2}{|c|}{$\begin{array}{c}\text { Numero de bactérias por } \\
\text { animal }\end{array}$} & \multirow{2}{*}{$\frac{\text { Sobrevivência }}{\text { Total de animais }}$} & \multirow{2}{*}{$\begin{array}{c}\text { Isolamento } \\
\text { de leptospira } \\
\text { do rim }\end{array}$} \\
\hline & & Em lâmina & $\begin{array}{l}\text { Em câmara } \\
\text { de Petroff }\end{array}$ & & \\
\hline 1 & $400 \mu 1$ (2doses) & $5 \times 10^{6}$ & $3 \times 10^{7}$ & $0 / 5(0)$ & - \\
\hline $2^{*}$ & $200 \mu 1$ & $2,5 \times 10^{6}$ & $1,5 \times 10^{7}$ & $0 / 10(0 \%)^{* *}$ & - \\
\hline 3 & $20 \mu 1(1: 10)$ & $2,5 \times 10^{5}$ & $1,5 \times 10^{6}$ & $0 / 5(0)$ & - \\
\hline 4 & $2 \mu 1(1: 100)$ & $2,5 \times 10^{4}$ & $1,5 \times 10^{5}$ & $2 / 5(40)$ & $0 / 2$ \\
\hline
\end{tabular}

* Dose do desafio dos grupos experimentais

** grupo experimental Nada 
Neste ensaio de imunização e desafio em hamsters não houve sobreviventes nos grupos experimentais exceto um animal no grupo imunizado com a salmonela recombinante apresentando a proteína Lip32 e todos os animais do grupo imunizado com a vacina comercial (Figura 53).

$\mathrm{O}$ resultado de isolamento de leptospiras dos rins de todos os animais sobreviventes foi negativo, embora o animal do grupo SLLip32 estivesse visivelmente doente e com um dos rins com aparência bastante afetada. 


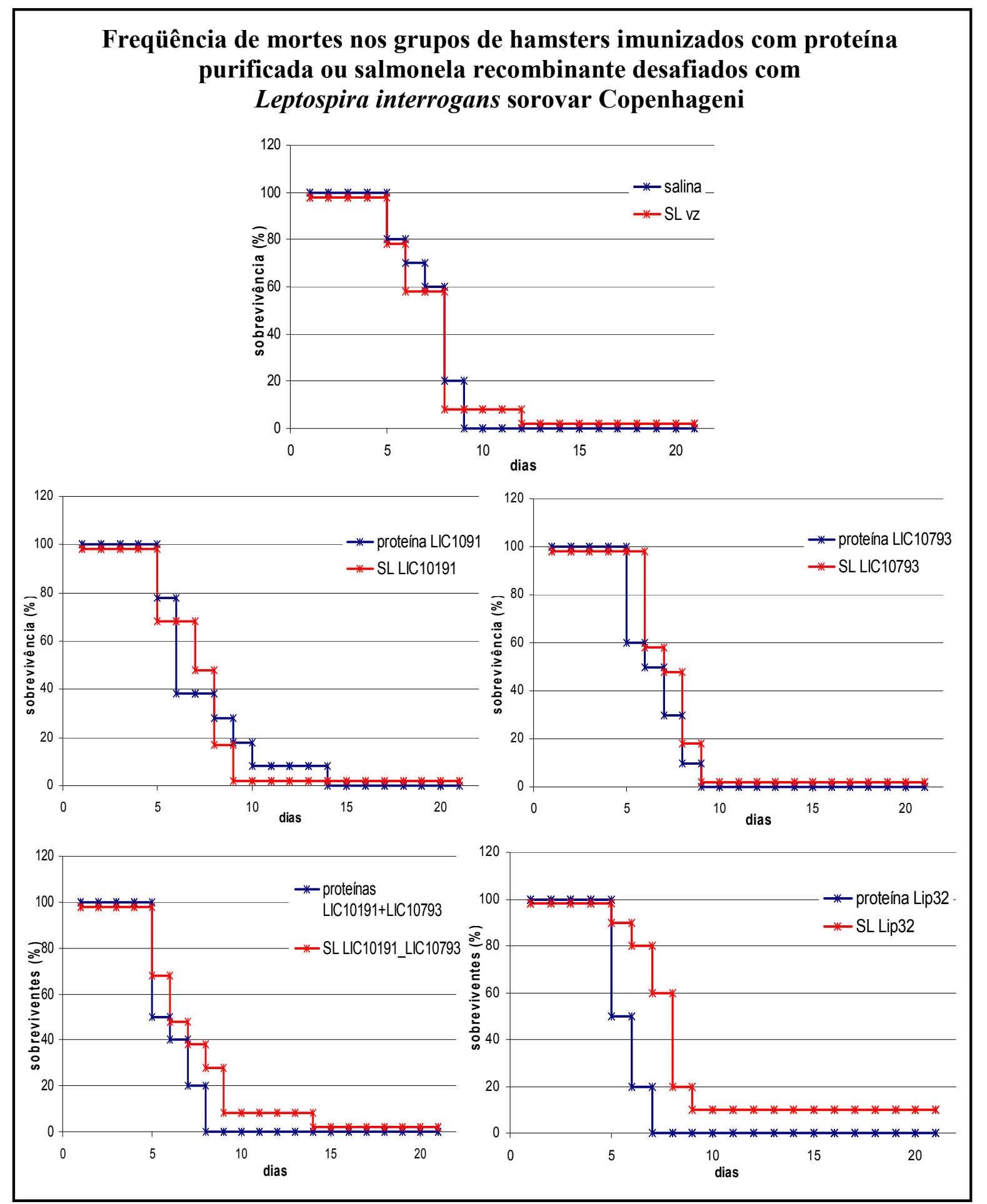

Figura 53 - Frequência de morte dos animais imunizados e desafiados com Leptospira interrogans sorovar Copenhageni. Os animais foram observados durante 21 dias após o desafio. As curvas comparam a frequência de mortes entre os animais imunizados com proteína purificada e salmonela recombinante apresentando a mesma proteina. 


\subsubsection{Determinação de anticorpos IgG no soro dos animais imunizados, por ELISA}

Os soros dos hamsters foram preparados individualmente a partir de sangue coletado quinze dias após cada imunização. Apresentamos os resultados de dosagem de IgG em cada grupo experimental, medidos por ELISA usando um "pool" de $20 \mu 1$ do soro de cada animal. As Figuras 54 e 55 apresentam as curvas de ELISA e os títulos de IgG verificados.

Podemos observar que os títulos de IgG anti-LIC10191 e anti-LIC10793 aumentam com as imunizações subseqüentes com as proteínas purificadas. No caso da proteína LIC10793 observamos menor indução de IgG em comparação com a LIC10191, porém, os títulos aumentaram quando a proteína foi administrada junto com a proteína LIC10191. O controle do ELISA medindo o reconhecimento da LIC10793 pelo soro dos animais do grupo salina revelou mais alto "background" quando comparado com o reconhecimento de LIC10191, indicando a presença de proteínas contaminantes de E. coli na preparação usada tanto nas imunizações como na sensibilização das placas de ELISA.

Os títulos de IgG anti-LIC10191 são baixos nos animais imunizados com ambas as salmonelas recombinantes, SLLIC10191 e SLLIC10191_LIC10793. A imunização com a salmonela sem plasmídeo também induziu anticorpos IgG que reconheceram as proteinas da preparação LIC10191 utilizada na sensibilização da placa. Esse resultado é esperado uma vez que a salmonela apresenta muitos antígenos homológos de E. coli, para os quais os animais são naturalmente sensibilizados.

Nos animais imunizados com as SLLIC10793 e SLLIC10191_LIC10793, os títulos anti-LIC10793 são mais elevados em relação aos títulos anti-LIC10191, porém, não podemos afirmar que seja IgG especifico anti-LIC10793 uma vez que há maior reconhecimento das proteinas na placa sensibilizada com a preparação LIC10793 pelo soro dos animais imunizados com SL vazia. O ensaio de western blot permite melhor avaliação do reconhecimento especifico. 


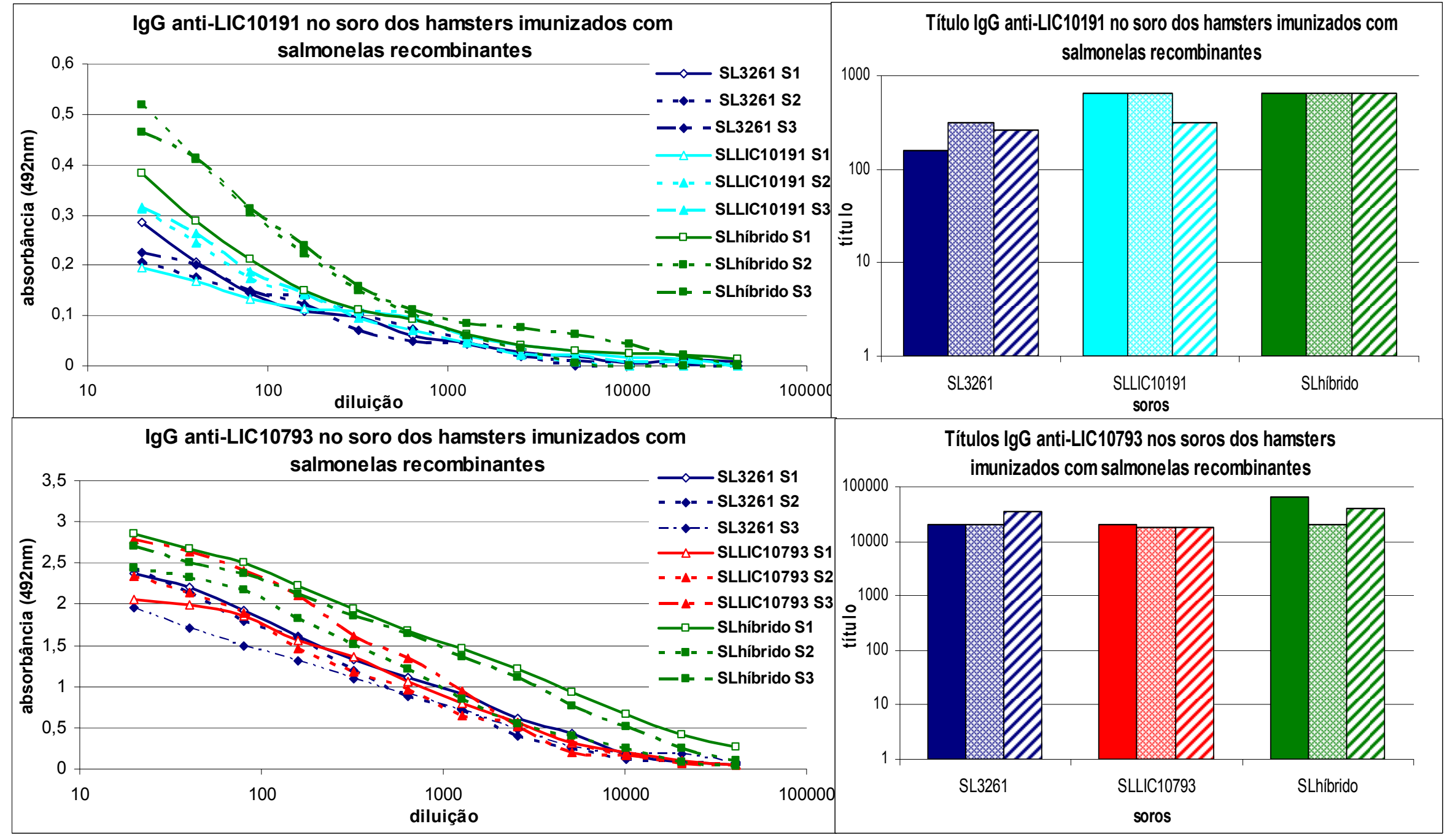

Figura 54 - Analise de IgG anti-LIC10191 e anti-LIC10793 nos soros dos hamsters imunizados com salmonelas recombinantes. Os gráficos mostram as curvas e os títulos de IgG gerados nas sangrias após cada imunização. As placas foram sensibilizadas com 500 ng de proteína por poço e a diluição dos soros foi iniciada em 1:20. As barras cheias, pontilhadas e hachuradas correspondem às sangrias S1, S2 e S3, respectivamente. 

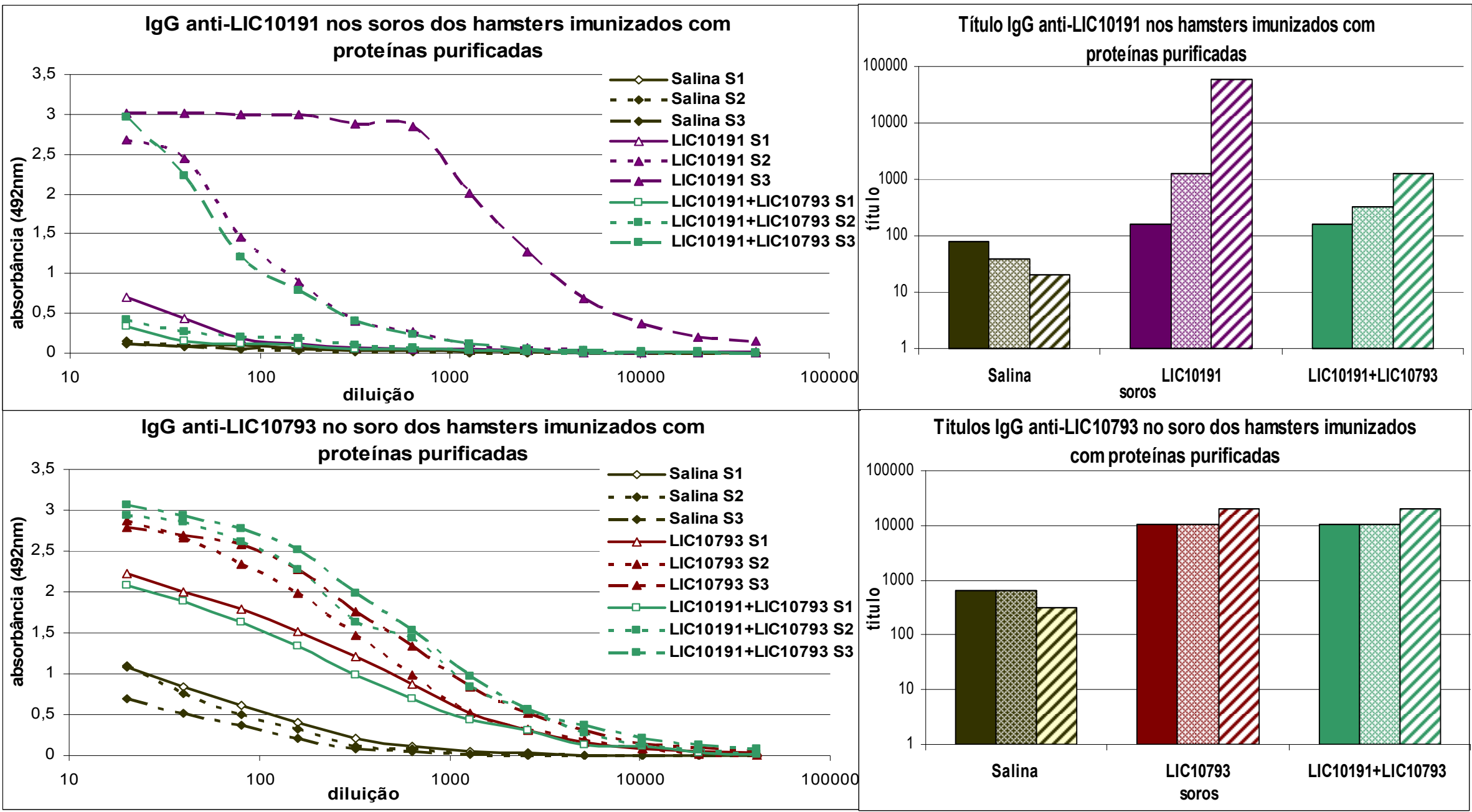

Figura 55 - Análise de IgG anti-LIC10191 e anti-LIC10793 nos soros dos hamsters imunizados com proteínas purificadas. Os gráficos mostram as curvas e os títulos de IgG gerados nas sangrias após cada imunização. As placas foram sensibilizadas com 500 ng de proteína por poço e a diluição dos soros foi iniciada em 1:20. As barras cheias, pontilhadas e hachuradas correspondem às sangrias S1, S2 e S3, respectivamente. 
Os ensaios de desafio realizados no laboratório indicam três antígenos mais promissores como candidatos vacinais ou para diagnóstico, LIC10191, Lip32 e ankB. Segundo dados da literatura, a proteína LigA foi apresentada como o melhor antígeno já testado, conferindo boa proteção dos animais, embora não determinando proteção esterilizante, ou seja, não elimina as bactérias do organismo do animal. Esses quatro antígenos foram incluídos no último ensaio de imunização e desafio desta fase do nosso projeto.

\subsubsection{Terceiro ensaio de imunização de hamsters e desafio com Leptospira interrogans sorovar Copenhageni}

No terceiro ensaio de imunização e desafio testamos os antígenos LIC10191, Lip32, LigA e ankB como proteínas purificadas ou expressas in vivo por salmonelas. Utilizamos, também, a salmonela carregando plasmídeo híbrido (pAEsoxLIC10191_Lip32). Testamos a administração de uma dose de proteína purificada LIC10191 entre duas doses de salmonela SLLIC190191, com objetivo de comparar o aumento de anticorpos com a imunização com três doses de salmonela. Além dissso, um grupo de animais foi imunizado com a SLLIC10191 juntamente com a proteína LigA.

Utilizamos 15 grupos de 10 hamsters (Mesocricetus auratus) machos de 42 dias marcados individualmente. Os animais foram imunizados 3 vezes por via intraperitoneal com $25 \mu \mathrm{g}$ de cada proteína ou $3 \times 10^{7}$ células de salmonela recombinante na primeira dose e $5 \times 10^{7}$ na segunda e terceira doses. $\mathrm{O}$ intervalo entre a primeira e segunda dose foi 21 dias, e 16 dias entre a segunda e terceira doses. Os grupos de imunização e doses estão descritos na Tabela 14.

Neste ensaio pretendiamos administrar apenas duas doses dos imunógenos, porém, houve dificuldade em isolar bactérias do fígado dos animais experimentalmente infectados, sendo que na data prevista para infeção não tínhamos um cultivo apropriado. Administramos a terceira dose dos imunógenos, enquanto realizávamos crescimento alternativo das leptospiras.

Retiramos as bactérias do meio semi-sólido Fletcher, transferimos para o meio liquido EMJH para cultivo por 10 dias. Para o desafio, consideramos que tínhamos uma cultura de segunda passagem e por isso aumentamos a dose de bactérias, inoculando $200 \mu \mathrm{l}$ da cultura pura por animal. Não foi possível contar as bactérias que se apresentavam muito pequenas ao microscópio. Fizemos uma curva de dose paralela ao desafio usando $400 \mu \mathrm{l}$ da cultura pura e $200 \mu \mathrm{l}$ das diluições $10^{-1}, 10^{-2}, 10^{-3}$ e $10^{-4}$. 
Tabela 14 - Grupos de imunização de hamsters e doses administradas via intraperitoneal para o desafio com Leptospira interrogans sorovar Copenhageni

\begin{tabular}{lccc}
\hline \multicolumn{1}{c}{ Grupos } & $\mathbf{1}^{\mathbf{0}}$ dose & $\mathbf{2}^{\mathbf{0}}$ dose & $\mathbf{3}^{\mathbf{0}}$ dose \\
\hline 1. controle salina & tampão fosfato & tampão fosfato & tampão fosfato \\
2. controle vacina comercial & dil 1:40 & dil $1: 40$ & dil 1:40 \\
3. proteína LIC10191 & $25 \mu \mathrm{g}$ & $25 \mu \mathrm{g}$ & $25 \mu \mathrm{g}$ \\
4. proteína Lip32 & $25 \mu \mathrm{g}$ & $25 \mu \mathrm{g}$ & $25 \mu \mathrm{g}$ \\
5. proteínas LIC10191 + Lip32 & $25 \mu \mathrm{g}$ de cada & $25 \mu \mathrm{g}$ de cada & $25 \mu \mathrm{g}$ de cada \\
proteína & proteína & proteína \\
6. proteína LigA & $25 \mu \mathrm{g}$ & $25 \mu \mathrm{g}$ & $25 \mu \mathrm{g}$ \\
7. proteína ankB & $25 \mu \mathrm{g}$ & $25 \mu \mathrm{g}$ & $25 \mu \mathrm{g}$ \\
8. controle SL3261 & $3 \times 10^{7}$ bactérias & $5 \times 10^{7}$ bactérias & $5 \times 10^{7}$ bactérias \\
9. SLLIC10191 & $3 \times 10^{7}$ bactérias & $5 \times 10^{7}$ bactérias & $5 \times 10^{7}$ bactérias \\
10. SLLip32 & $3 \times 10^{7}$ bactérias & $5 \times 10^{7}$ bactérias & $5 \times 10^{7}$ bactérias \\
11. SLLIC10191_Lip32 & $3 \times 10^{7}$ bactérias & $5 \times 10^{7}$ bactérias & $5 \times 10^{7}$ bactérias \\
12. SLLigA & $3 \times 10^{7}$ bactérias & $5 \times 10^{7}$ bactérias & $5 \times 10^{7}$ bactérias \\
13. SLankB & $3 \times 10^{7}$ bactérias & $5 \times 10^{7}$ bactérias & $5 \times 10^{7}$ bactérias \\
14. SLLIC10191 + booster de & $3 \times 10^{7}$ bactérias & $25 \mu \mathrm{g}$ proteína & $5 \times 10^{7}$ bactérias \\
proteína LIC10191 & $3 \times 10^{7}$ bactérias + & $5 \times 10^{7}$ bactérias + & $5 \times 10^{7}$ bactérias + \\
15. SLLIC10191 + LigA purificada & $25 \mu \mathrm{g}$ proteína & $25 \mu \mathrm{g}$ proteína & $25 \mu \mathrm{g}$ proteína \\
\hline
\end{tabular}

Os animais foram desafiados com Leptospira interrogans sorovar Copenhageni 21 dias após a terceira dose.

Após o inóculo com Leptospira interrogans sorovar Copenhageni, os animais foram observados por 15 dias e ocorreram poucas mortes em diferentes grupos. Considerando os ensaios de desafio realizados por nosso grupo e por grupos colaboradores, em geral a dose de desafio com Leptospira interrogans sorovar Copenhageni deve matar os animais do grupo controle em até 10 dias. Neste ensaio houve grande número de sobreviventes, tanto nos grupos imunizados, como nos grupos controle, indicando problema no ensaio de desafio. As causas para a alta taxa de sobreviventes poderiam estar relacionadas à infecção subletal, não devido a baixo número de leptospiras, mas à perda de virulencia. De fato o crescimento das bactérias a partir do meio semi-sólido Fletcher pode ter afetado a virulência da bactéria. 
Ainda o fato dos animais estarem mais velhos também implicaria na maior resistência ao desafio.

A despeito dos diversos controles e ensaios realizados para minimizar as dificuldades dos ensaios de desafio, este ultimo ensaio apresentou a dificuldade de isolamento da leptospira do infectado experimentalmente e não permitiu elaborar nenhuma análise de imunoproteção. O mesmo ensaio será reproduzido oportunamente, uma vez que o grupo de antígenos e as suas formas de apresentação resumem os candidatos vacinais mais interessentes do laboratório. Por questões de prazos, os resultados deste ensaio não serão apresentados nesta tese, embora venham a completar este trabalho.

\subsubsection{Determinação de IgG no soro dos animais imunizados por ELISA}

No terceiro ensaio de imunização e desafio os soros dos animais foram preparados a partir das sangrias realizadas dois dias antes e quinze dias após a terceira imunização. Os soros foram testados por ELISA quanto ao reconhecimento das proteínas recombinantes. As Figuras 56 a 62 ilustam os resultados dos ELISAs.

Podemos observar pelos gráficos dos ELISAs que as proteínas e as salmonelas recombinantes foram capazes de induzir a produção de anticorpos IgG.

A proteína LIC10191 se mostrou menos imunogênica do que as demais proteínas utilizadas no ensaio, Lip32, LigA e ankB, mesmo na co-administração com a proteína Lip32 (Figuras 56 e 57). Os títulos de IgG anti-LIC10191 no soro dos hamsters imunizados com a proteína purificada são mais baixos do que os observados no soro dos camundongos, apesar do aumento da dose em cinco vezes. Esse dado indica a variabilidade de resposta entre os modelos animais.

A SLLIC10191 gerou baixos títulos de IgG anti-LIC10191 como esperado, porém os títulos dos animais imunizados com a SLLIC10191_Lip32 foram um pouco mais elevados. A Figura 58 mostra que na co-administração da SLLIC10191 com LigA os títulos de IgG antiLIC10191 foram mais altos do que no soro dos animais imunizados apenas com a SLLIC10191 ou imunizados com duas doses de SLLIC10191 e uma dose de proteína purificada. A proteína LigA foi capaz de aumentar a resposta de anticorpo contra a LIC10191 expressa pela salmonela in vivo, sugerindo certa capacidade adjuvante.

A proteína Lip32 se mostrou bastante imunogênica atingindo títulos de IgG de aproximadamente 1.000.000 (Figura 59). Na co-administração com a LIC10191, a Lip32 induziu títulos semelhantes. 
Podemos observar pelo gráfico Figura 59 que a segunda dose de proteína foi suficiente para levantar altos títulos de IgG e que a terceira dose foi menos importante. Esse dado é interessante uma vez que a administração da terceira dose prolonga o cronograma de imunização e, consequentemente, temos os animais mais velhos no momento do desafio. Sabemos, por outros ensaios do laboratório, que a idade do animal é um ponto a ser considerado nos ensaios de desafio por leptospiras e quanto mais velhos, mais resistentes a infecção.

Obtivemos baixos títulos de IgG anti-Lip32 no soro dos animais imunizados com a SLLip32, porém, semelhante ao que ocorreu com a LIC10191, os títulos foram maiores no soro dos animais imunizados com a salmonela apresentando os dois antígenos simultaneamente, a SLLIC10191_Lip32 (Figura 60).

A proteína LigA se mostrou bastante imunogênica atingindo títulos de $\operatorname{IgG}$ de 512.000. A SLLigA induziu baixos títulos de IgG, como esperado (Figura 61). Interessante notar que a co-administração da proteína LigA com a SLLIC10191 elevou consideravelmente os títulos de IgG anti-LigA. A SLLIC10191 aumentou a resposta de anticorpos IgG antiLigA, sugerido a ação adjuvante da salmonela.

A proteína ankB induziu altos títulos de anticorpos IgG (Figura 62), porém, a resposta observada não é específica para a proteína, uma vez que o soro dos animais imunizados apenas com a salmonela vazia também atingiu títulos altos de IgG anti-ankB. Devemos considerar que a proteína ankB foi purificada com muitos contaminantes do extrato solúvel de salmonela. As proteínas contaminantes interferiram bastante tanto na imunização quanto na sensibilização da placa de ELISA, este reconhecimento inespecífico pode ser comprovado no reconhecimento de bandas espúrias no teste de western blot. 


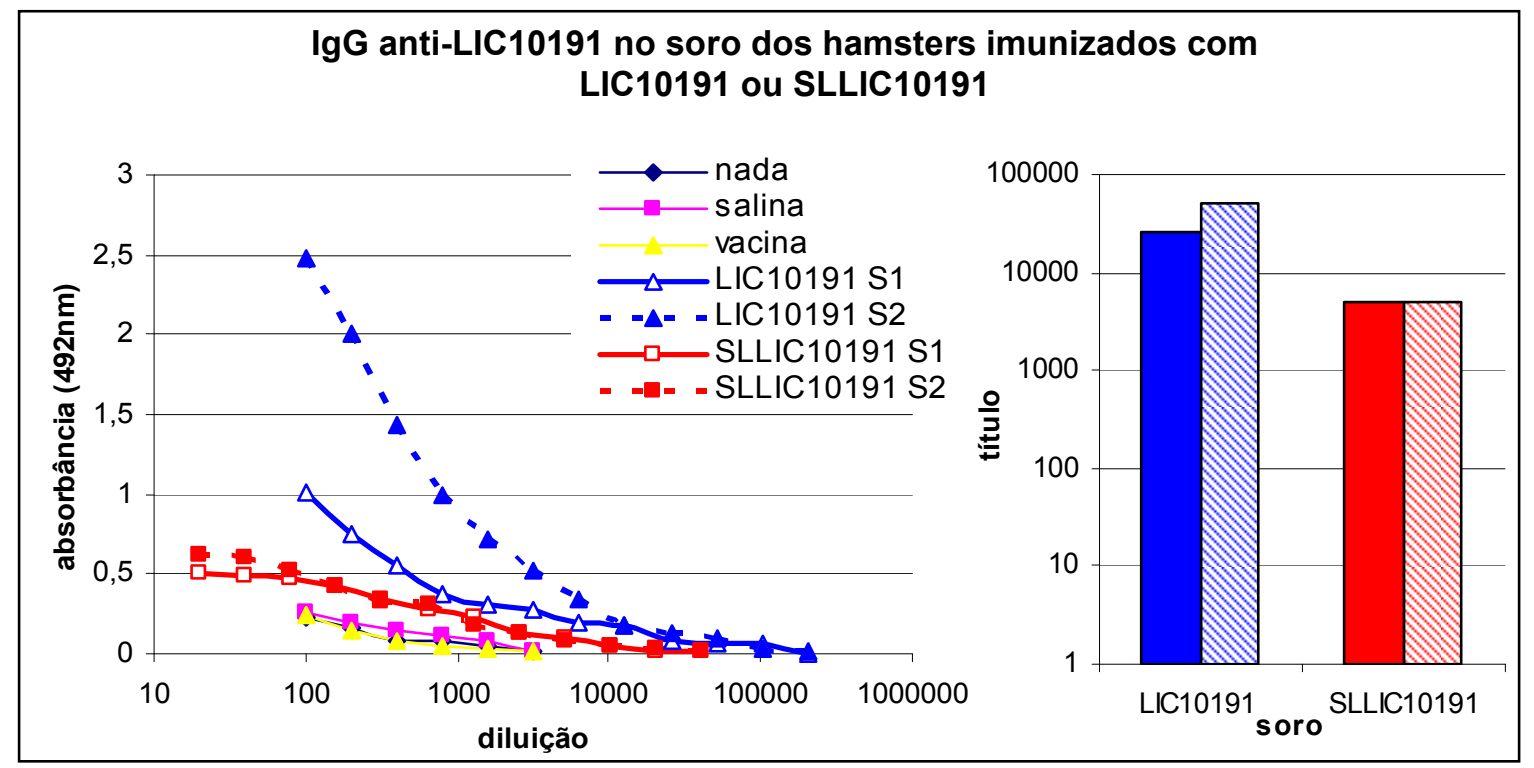

Figura 56 - Análise de IgG anti-LIC10191 dos hamsters imunizados com proteína LIC10191 purificada ou SLLIC10191. Os gráficos mostram as curvas e os títulos de IgG gerados nas sangrias após a $2^{\circ}$ e $3^{\circ}$ doses (S1 e S2). As placas foram sensibilizadas com $500 \mathrm{ng}$ de proteína por poço e a diluição dos soros foi iniciada em 1:20 ou 1:100. As barras cheias e hachuradas correspondem às sangrias $\mathrm{S} 1$ e S2, respectivamente.

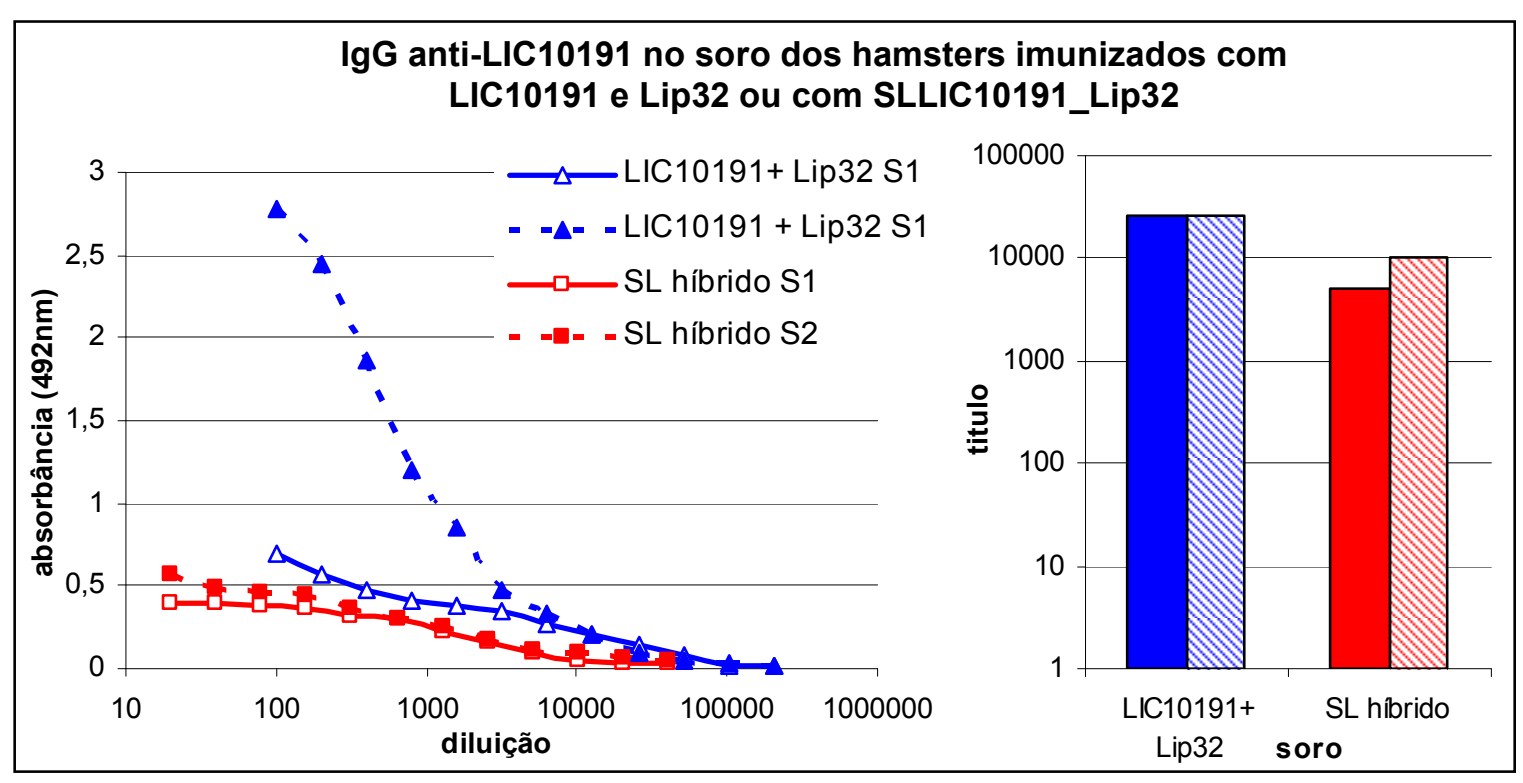

Figura 57 - Análise de IgG anti-LIC10191 ns soros dos hamsters imunizados com as proteínas LIC10191 e Lip32 purificadas e SLLIC10191_Lip32. Os gráficos mostram as curvas e os títulos de IgG gerados nas sangrias após a $\overline{2^{\circ}}$ e $3^{\circ}$ dose (S1 e S2). As placas foram sensibilizadas com $500 \mathrm{ng}$ de proteína por poço e a diluição dos soros foi iniciada 1:20 ou 1:100. As barras cheias e hachuradas correspondem às sangrias S1 e S2, respectivamente. 


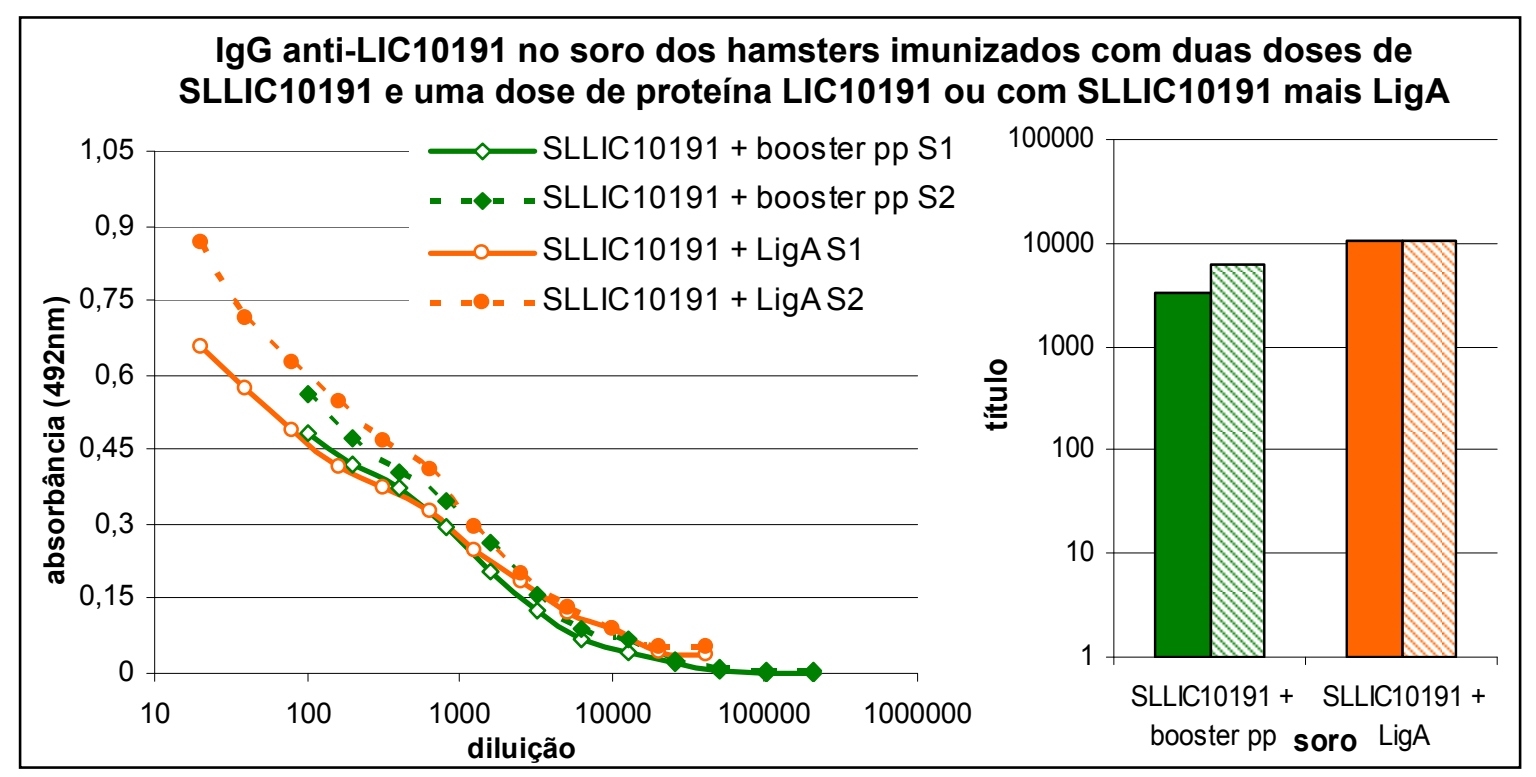

Figura 58 - Análise de IgG anti-LIC10191 nos soros dos hamsters imunizados com SLLIC10191 e reforço proteína LIC10191 purificada ou imunizados com SLLIC10191 mais LigA purificada. Os gráficos mostram as curvas e os títulos de IgG gerados nas sangrias após a $2^{\circ}$ e $3^{\circ}$ dose (S1 e S2). As placas foram sensibilizadas com $500 \mathrm{ng}$ de proteína por poço e a diluição dos soros foi iniciada 1:10 ou 1:100. As barras cheias e hachuradas correspondem às sangrias $\mathrm{S} 1 \mathrm{e} \mathrm{S} 2$, respectivamente.

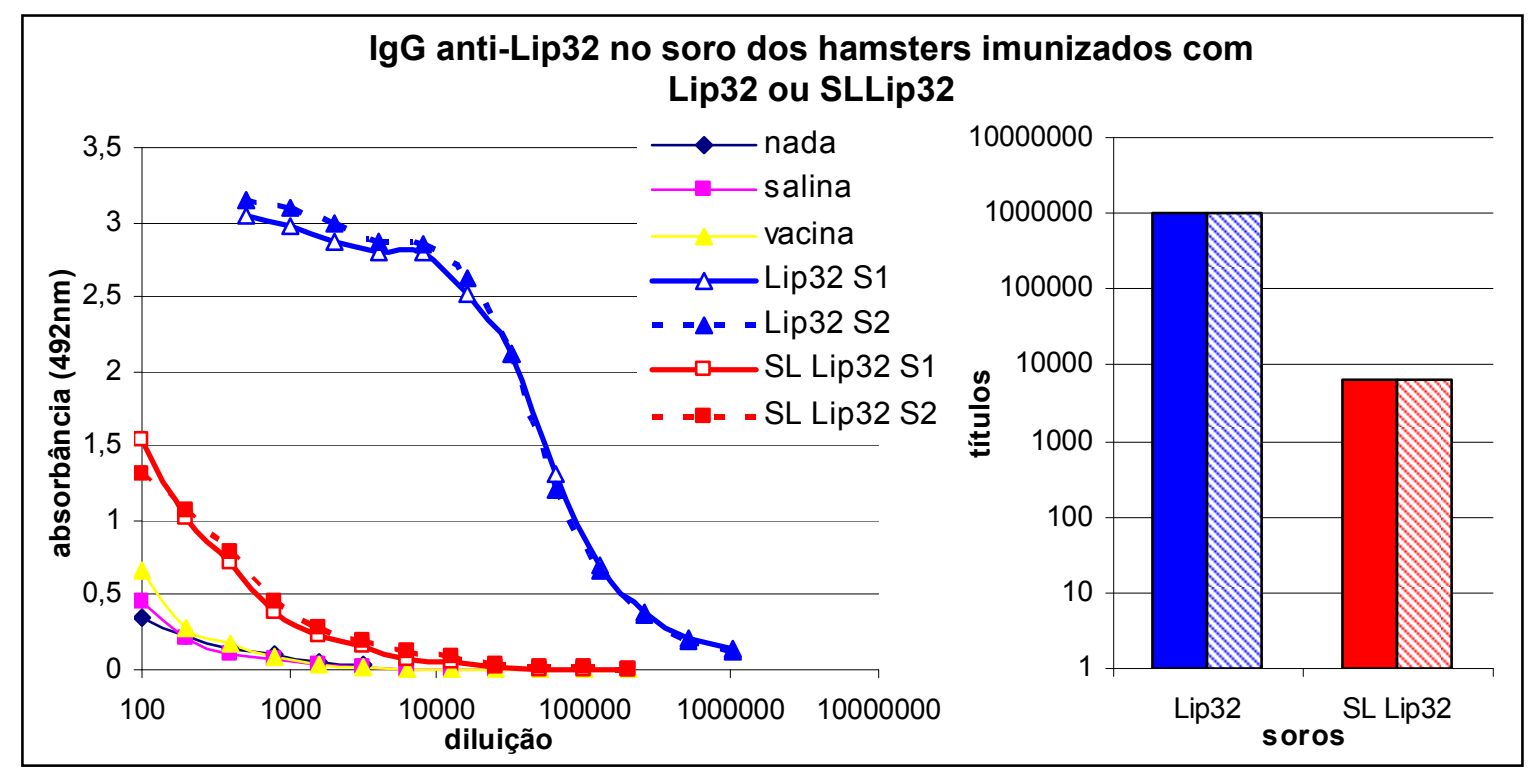

Figura 59 - Análise de IgG anti-Lip32 nos soros dos hamsters imunizados com proteína Lip32 purificada ou SLLip32. Os gráficos mostram as curvas e os títulos de IgG gerados nas sangrias após a $2^{\circ}$ e $3^{\circ}$ dose (S1 e S2). As placas foram sensibilizadas com $500 \mathrm{ng}$ de proteína por poço e a diluição dos soros foi iniciada 1:100 ou 1:500. As barras cheias e hachuradas correspondem às sangrias $\mathrm{S} 1$ e $\mathrm{S} 2$, respectivamente. 


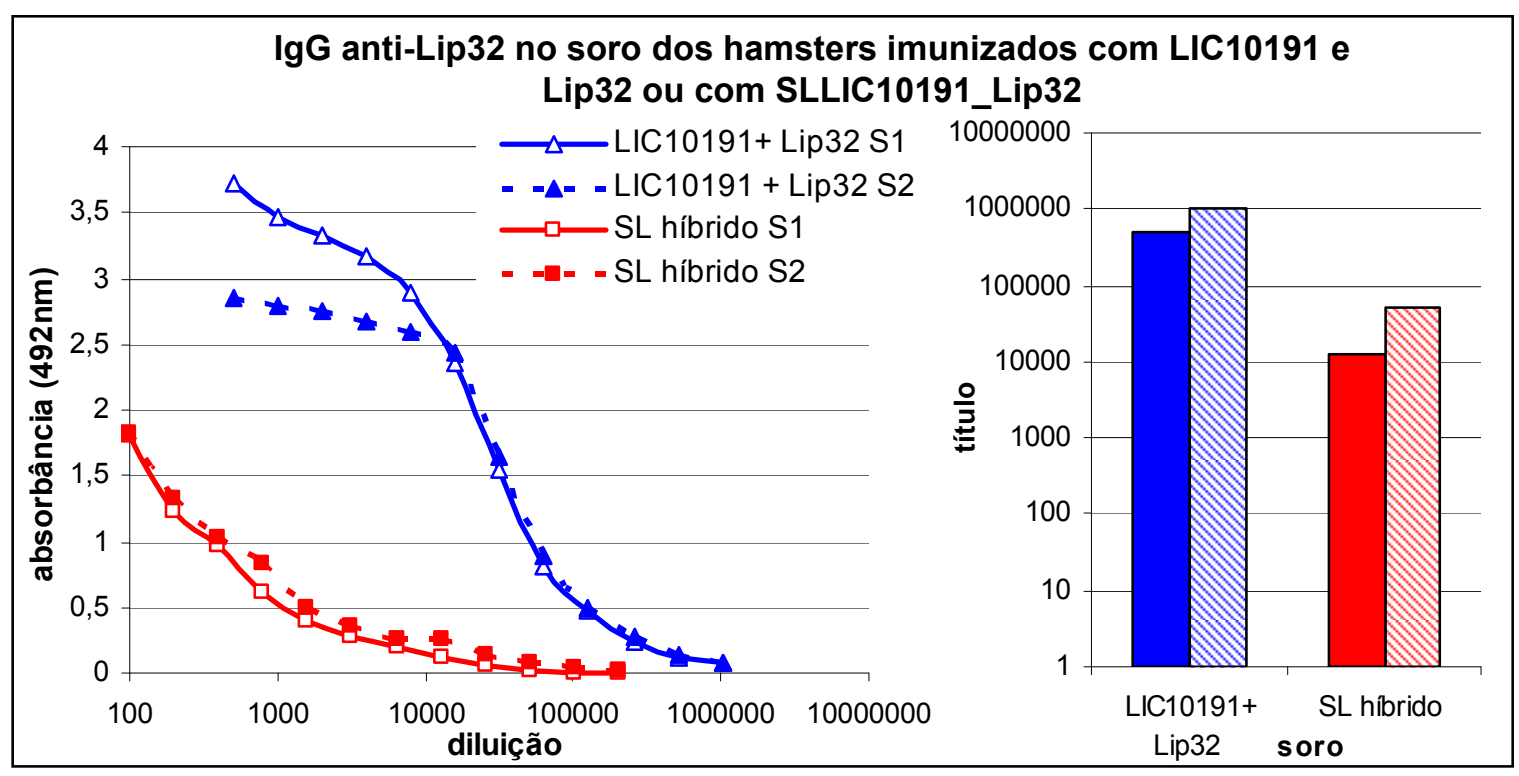

Figura 60 - Análise de IgG anti-Lip32 nos soros dos hamsters imunizados com as proteínas LIC10191 e Lip32 purificadas ou com SLLIC10191_Lip32. Os gráficos mostram as curvas e os títulos de IgG gerados nas sangrias após a $\overline{2}^{\circ}$ e $3^{\circ}$ dose (S1 e S2). As placas foram sensibilizadas com $500 \mathrm{ng}$ de proteína por poço e a diluição dos soros foi iniciada 1:100 ou 1:500. As barras cheias e hachuradas correspondem às sangrias S1 e S2, respectivamente.

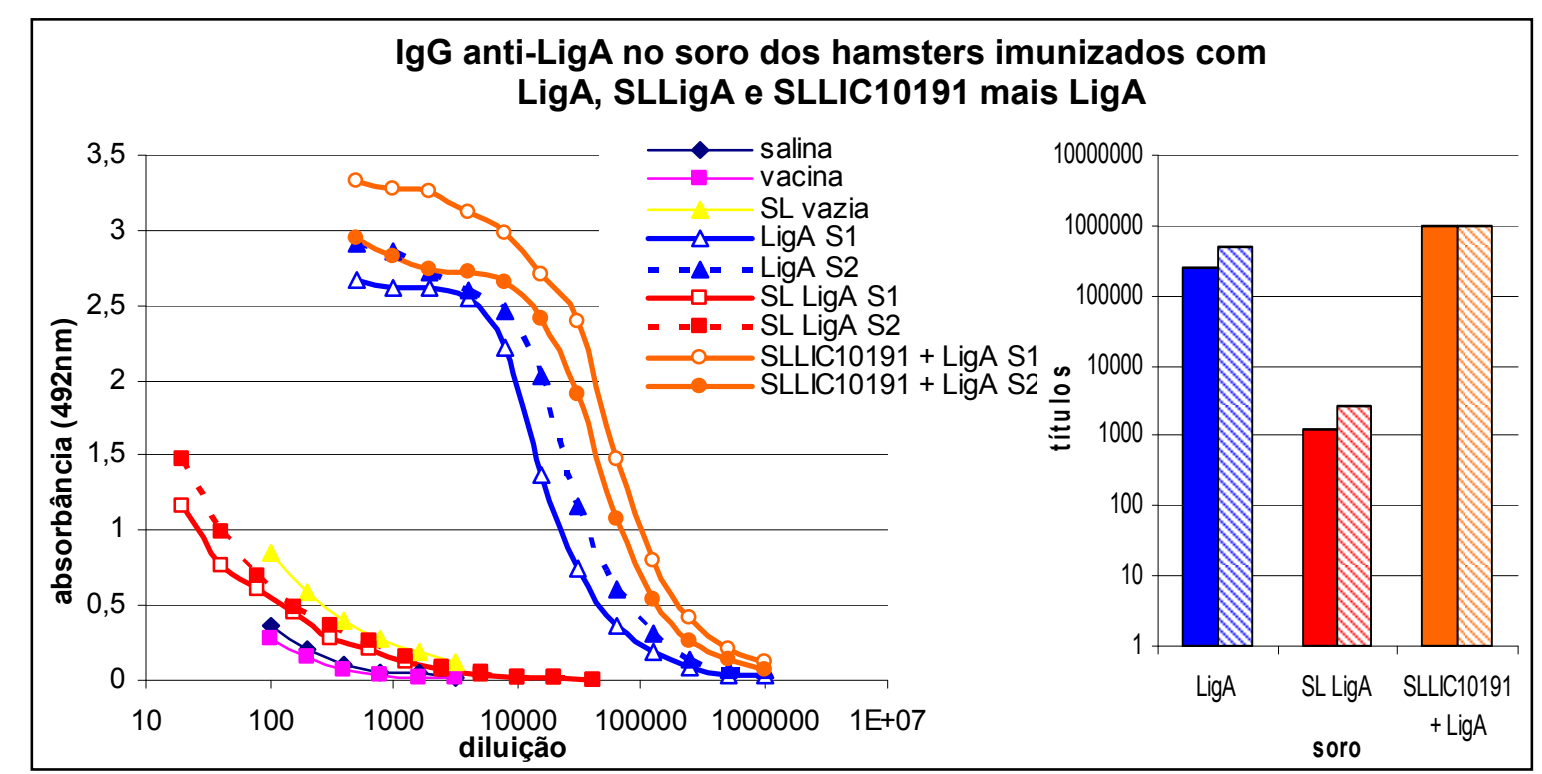

Figura 61 - Análise de IgG anti-LigA nos soros dos hamsters imunizados com proteína LigA purificada ou com SLLigA. Os gráficos mostram as curvas e os títulos de IgG gerados nas sangrias após a $2^{\circ}$ e $3^{\circ}$ dose (S1 e S2). As placas foram sensibilizadas com $500 \mathrm{ng}$ de proteína por poço e a diluição dos soros foi iniciada 1:20, 1:100 ou 1:500. As barras cheias e hachuradas correspondem às sangrias $\mathrm{S} 1 \mathrm{e} \mathrm{S} 2$, respectivamente. 


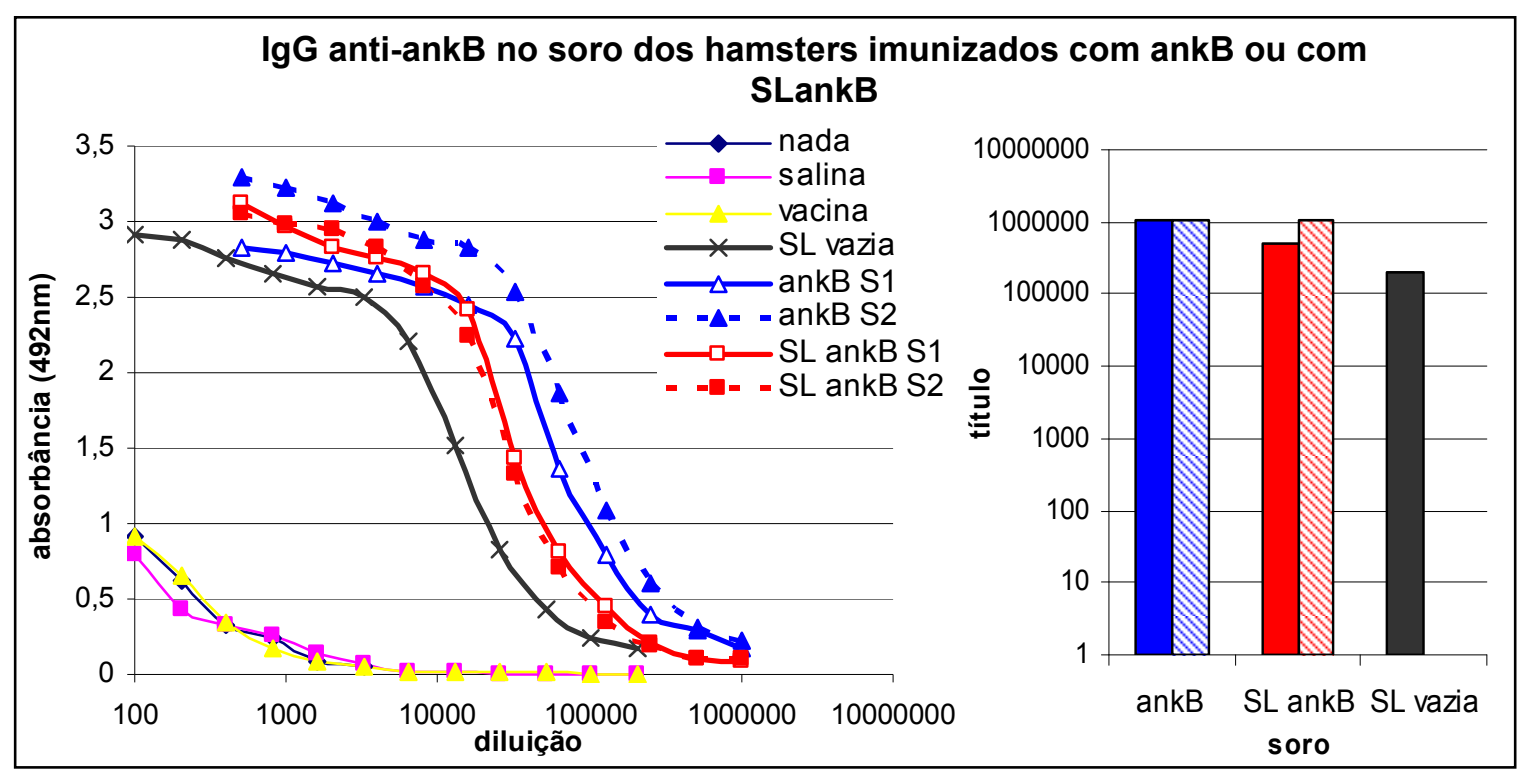

Figura 62 - Análise de IgG anti-ankB nos soros dos hamsters imunizados com proteína AnkB purificada ou SLAnkB. Os gráficos mostram as curvas e os títulos de IgG gerados nas sangrias após a $2^{\circ}$ e $3^{\circ}$ dose (S1 e S2). As placas foram sensibilizadas com $500 \mathrm{ng}$ de proteína por poço e a diluição dos soros foi iniciada 1:100 ou 1:500. As barras cheias e hachuradas correspondem às sangrias $\mathrm{S} 1 \mathrm{e} \mathrm{S} 2$, respectivamente.

4.9.4.2 Avaliação do reconhecimento dos antígenos por anticorpos específicos dos soros dos animais imunizados, por Western Blot

Os soros dos hamsters imunizados foram usados em ensaios de Western Blot para verificar o reconhecimento específico dos anticorpos sobre as proteínas LIC10191, Lip32, LigA e ankB. A Figura 63A mostra o perfil das proteínas em SDS-PAGE e a Figura 63B o perfil das proteínas após transferência para membranas. Como controles foram usados os soros de animais que receberam somente salina/Alhydrogel e controle salmonela (sem vetor de expressão). Também foi usado soro dos animais vacinados com a vacina comercial, soro dos animais imunizados com as proteínas purificadas LIC10191, Lip32, LigA e ankB e com as salmonelas recombinantes apresentando esses mesmos antígenos. Todos os soros foram introduzidos na diluição 1:1000.

Podemos observar que não há reconhecimento das proteínas purificadas pelo soro dos grupos salina/Alhydrogel e vacina comercial. Verifica-se forte reconhecimento da proteína ankB e dos contaminantes presentes na preparação pelo soro do grupo salmonela vazia (Figura 63D). Esse dado confirma o resultado obtido no ELISA, no qual observamos alto título de IgG. As proteínas recombinantes foram fortemente reconhecidas pelo soro dos 
animais imunizados com as mesmas, como observado nos ELISAs. Nota-se o reconhecimento específico das proteínas Lip32, LigA e ankB determinando bandas intensas nas membranas de western blot, diferente do que se observa com a LIC10191 (Figura 64). A LIC10191 de fato não levantou altos títulos de $\operatorname{IgG}$ nos hamsters imunizados e determinou somente uma banda bem tênue no western blot. Uma banda bem intensa de reconhecimento da Lip32 foi determinada na membrana incubada com o soro dos animais imunizados com ambas proteínas LIC10191 e Lip32 (Figura 65M). Esse dado reforça a observação de que a LIC10191 é menos imunogênica em hamsters.

As proteínas LigA e ankB também foram reconhecidas pelo soro dos grupos SLLigA e SLankB, porém com menor intensidade do que a observada com o soro dos grupos imunizados com as proteínas purificadas (Figuras 64I, 64J, 64K e 64L). As proteínas Lip32 e LIC10191 não foram reconhecidas pelo soro dos grupos SLLip32 e SLLIC10191, entretanto, observamos o reconhecimento da proteína Lip32 pelo soro do grupo imunizado com a SLLIC10191_Lip32 (Figura 65N). De acordo com as curvas de ELISA, a salmonela carregando os dois antígenos induziu mais anticorpos IgG contra a Lip32 do que a salmonela carregando apenas a Lip32. As diferenças de apresentação de antigenos pelos clones individuais podem estar relacionadas com diferenças casuais na invasão e permanência das salmonelas nos animais. Não podemos afirmar que ocorram diferenças dos clones diretamente relacionadas com os antígenos sem melhores investigações.

Observa-se uma banda tênue de reconhecimento da LIC10191 pelo soro dos animais que receberam uma dose de proteína purificada entre duas doses de SLLIC10191. O reconhecimento da proteína foi maior na membrana incubada com soro de animais imunizados com SLLIC10191 mais a proteína LigA, sugerindo o efeito adjuvante da proteína LigA. A Tabela 15 resume os resultados obtidos nos ensaios de western blot. 
Tabela 15 - Intensidade relativa do reconhecimento das proteínas LIC10191, Lip32, LigA e ankB no soro dos hamsters imunizados. Avaliação das Figuras 64 e 65.

\begin{tabular}{|c|c|c|c|c|}
\hline \multirow{2}{*}{ Gruposde imunização } & \multicolumn{4}{|c|}{ Reconhecimento de IgG específico } \\
\hline & LIC10191 & Lip32 & LigA & AnkB \\
\hline 3. proteína LIC10191 & ++ & $\mathrm{X}$ & $\mathrm{X}$ & $\mathrm{X}$ \\
\hline 4. proteína Lip32 & $\mathrm{X}$ & +++ & $\mathrm{X}$ & $\mathrm{X}$ \\
\hline 5. proteínas LIC10191 + Lip32 & + & +++ & $\mathrm{X}$ & $\mathrm{X}$ \\
\hline 6. proteína LigA & $\mathrm{X}$ & $\mathrm{X}$ & ++++ & $\mathrm{X}$ \\
\hline 7. proteína ankB & $\mathrm{X}$ & $\mathrm{X}$ & $\mathrm{X}$ & +++ \\
\hline 9. SLLIC10191 & + & $\mathrm{X}$ & $\mathrm{X}$ & $\mathrm{X}$ \\
\hline 10. SLLip32 & + & $\mathrm{X}$ & $\mathrm{X}$ & $\mathrm{X}$ \\
\hline 11. SLLIC10191_Lip32 & - & + & $\mathrm{X}$ & $\mathrm{X}$ \\
\hline 12. SLLigA & $\mathrm{X}$ & $\mathrm{X}$ & ++ & $\mathrm{X}$ \\
\hline 13. SLankB & $\mathrm{X}$ & $\mathrm{X}$ & $\mathrm{X}$ & ++ \\
\hline $\begin{array}{l}\text { 14. SLLIC10191 + reforço de proteína } \\
\text { LIC10191 }\end{array}$ & + & $\mathrm{X}$ & $\mathrm{X}$ & $\mathrm{X}$ \\
\hline 15. SLLIC10191 + LigA purificada & + & $\mathrm{X}$ & ++++ & \\
\hline
\end{tabular}

+: reconheceu/ -: não reconheceu/ X: não realizado 

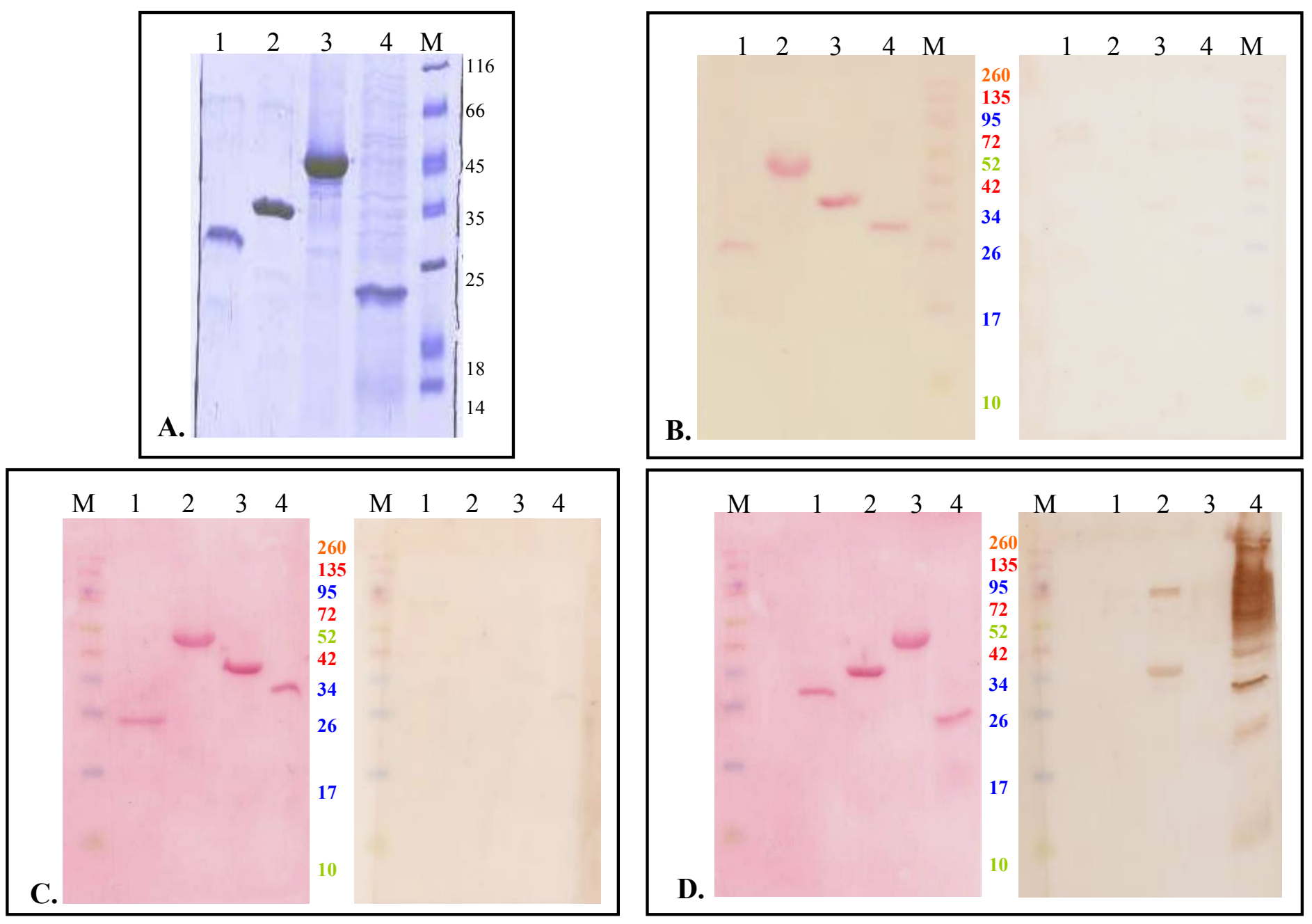

Figura 63 - Análise do reconhecimento das proteínas recombinantes purificadas pelo soro de animais dos grupos controle. A) SDS-PAGE com as proteínas purificadas corado com comassie, canaletas: 1 - LIC10191, 2 - Lip32, 3 - LigA e 4 - ankB. M- marcador de massa molecular. B) soro do grupo controle salina; C) soro do grupo controle vacina comercial e D) soro do grupo controle salmonela vazia. 

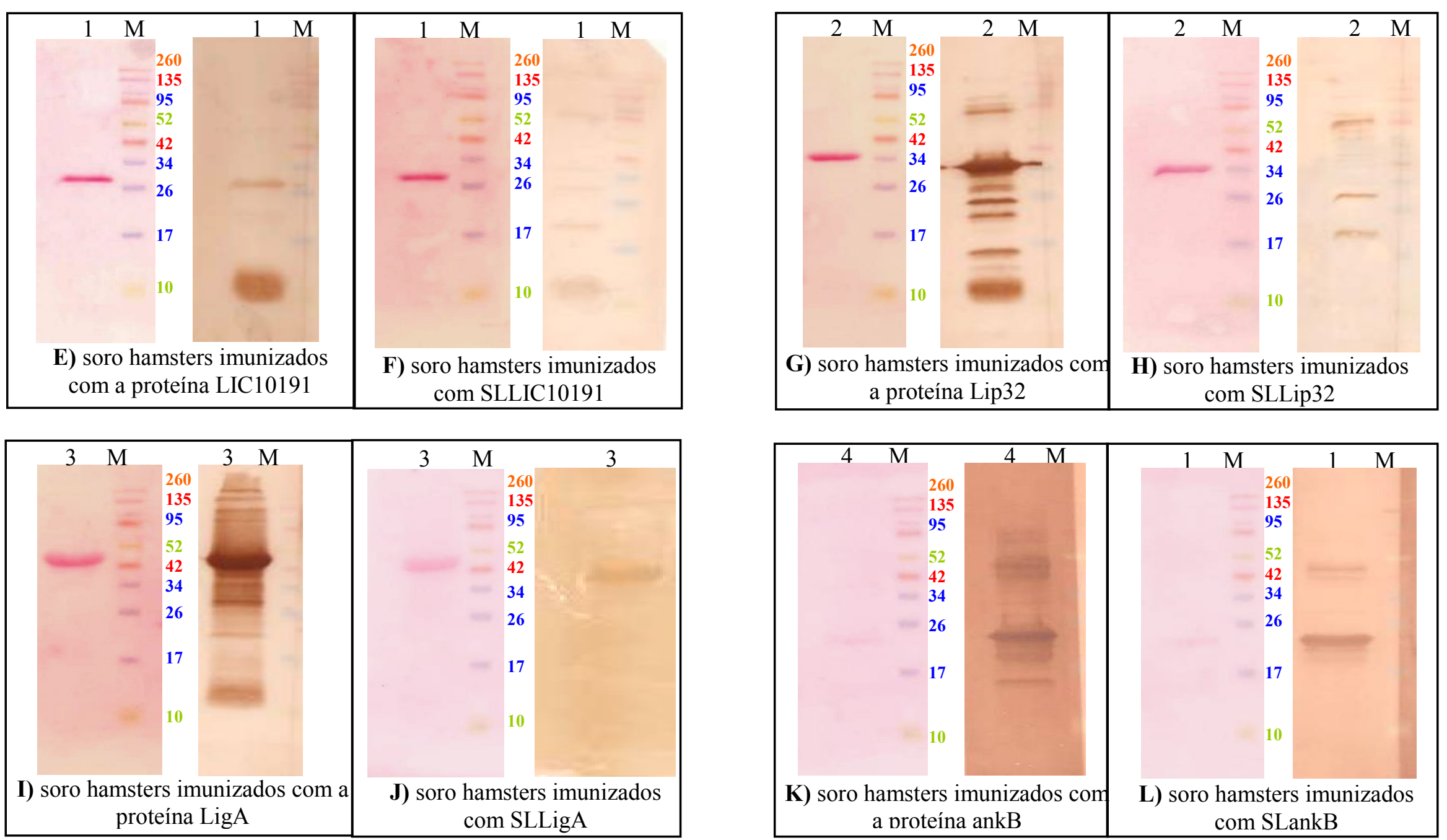

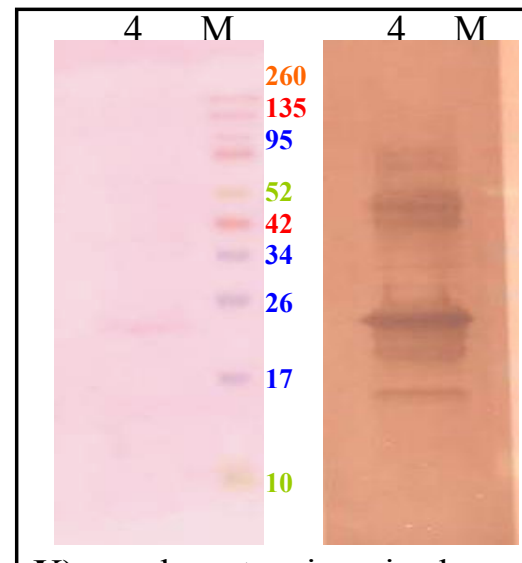

K) soro hamsters imunizados con a proteína ankB

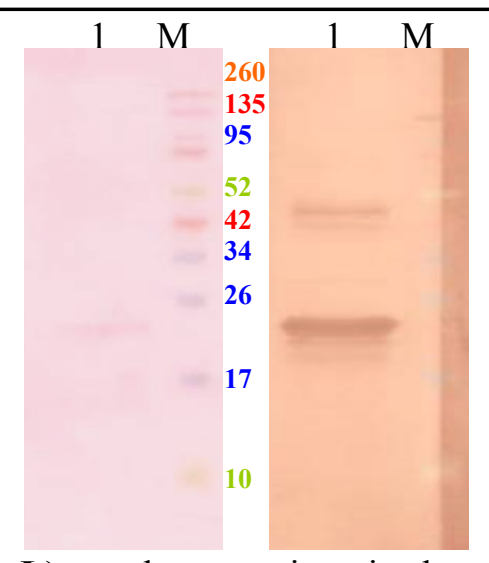

L) soro hamsters imunizados com SLankB

Figura 64 - Análise do reconhecimento das proteínas recombinantes purificadas pelo soro de animais dos grupos imunizados com as proteínas purificadas LIC10191, Lip32, ankB e LigA e com as salmonelas recombinantes. Canaletas: 1 - LIC10191, 2 - Lip32, 3 - LigA e 4 - ankB. M- marcador de massa molecular. As membranas foram incubadas com os soros indicados em cada quadro. 

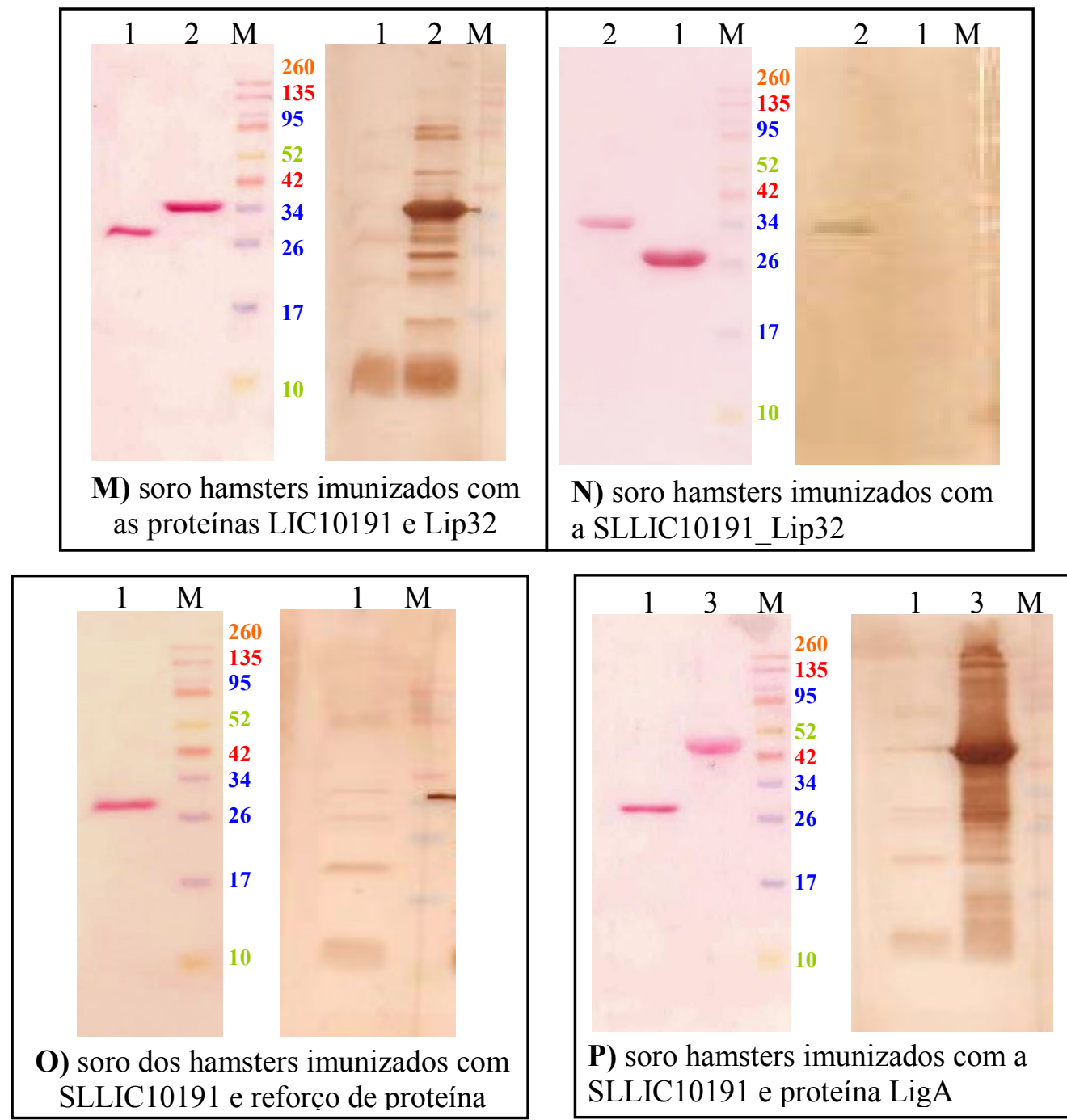

Figura 65 - Análise do reconhecimento das proteínas recombinantes purificadas pelo soro de animais dos grupos imunizados com as proteínas purificadas LIC10191 e Lip21, SLLIC10191_Lip32 e a SLLIC10191 com LigA ou reforço de proteína. Canaletas: 1 - LIC10191, 2 - Lip32, 3 - LigA e 4 - ankB. M- marcador de massa molecular. As membranas foram incubadas com os soros descritos abaixo de cada figura. 


\section{DISCUSSÃO}

A análise da antigenicidade de proteínas recombinantes purificadas é uma ferramenta importante na descoberta de possíveis candidatos a testes de diagnóstico. O reconhecimento das proteínas recombinantes pelo soro de um paciente de leptospirose indicou, dentre as proteínas estudadas, quais são mais antigênicas. As proteínas LIC10325 (HlyX) e LIC11352 (Lip32) foram reconhecidas pelos anticorpos $\operatorname{IgG}$ e $\operatorname{IgM}$ do soro do paciente, corroborando dados da literatura. A proteína Lip32 é o antígeno mais abundante de leptospira durante a infecção (HAAKE et al., 2000) e foi apresentado como bom candidato para testes de diagnóstico devido sua alta imunogenicidade (FLANERY et al., 2001; DEY et al., 2004). A proteína HlyX foi caracterizada como hemolisina por ser capaz de causar hemólise de eritrócitos in vitro (HAUK et al., 2005). Em nosso projeto utilizamos essas duas proteínas recombinantes purificadas como controle positivo nos ensaios de western blot. De fato, as duas proteínas foram bem reconhecidas pelo soro do paciente com leptospirose, mesmo quando em pequena quantidade na membrana.

As proteínas LIC10508 (LipL23) e LIC12631 (Sph2) também foram bem reconhecidas pelo soro do paciente de leptospirose. A proteína Sph2 é expressa pela leptospira quando cultivada in vitro e durante infecção, mas a imunização de hamsters com a proteína não foi capaz determinar proteção contra leptospirose (CARVALHO et al., 2009), indicando que seria um bom candidato para teste de diagnóstico, mas não para formular uma vacina. Interessante notar que a proteína LIC12660 (VapC) foi reconhecida por anticorpos do soro do paciente de leptospirose enquanto a proteína LIC12659 (VapB) não é. As duas proteínas foram caracterizadas como fatores de virulência de leptospira e análises genômicas in silico indicaram que os dois genes formam um operon, o qual foi denominado operon vapBC (LOPES, 2009). Segundo dados da literatura, a expressão da proteína VapC em E. coli inibiu o crescimento da bactéria. Este crescimento foi normalizado quando havia co-expressão da proteína VapB (ZHANG et al., 2004). A proteína VapC de Haemophilus influenza foi caracterizada como uma toxina com atividade ribonuclease e essa atividade era neutralizada pela proteína VapB, caracterizada como uma antitoxina (DAINES et al., 2007). Ainda segundo a literatura a proteína VapC seria mais estável que a VapB. Ensaios do laboratório mostram que as proteínas VapB e VapC foram igualmente imunogênicas. Desta forma, para explicar a maior antigenicidade da VapC, cogitamos que, devido ao estresse sofrido pela bactéria durante a infecção, a toxina seria liberada do complexo e seria melhor apresentada ao sistema imune do hospedeiro, uma vez que a antitoxina seria mais rapidamente degradada. 
As proteínas LIC10191 e LIC10793 também foram reconhecidas por anticorpos IgG e IgM do soro do paciente de leptospirose. Esses dados corroboram resultados da literatura. A proteína LIC10793 mostrou-se mais antigênica, e de fato foi proposta como bom antígeno para diagnóstico, também por ser conservada entre as espécies patogênicas e por ser reconhecida por soro de pacientes nos estágios iniciais da doença, quando o diagnóstico por MAT não é confiável (NEVES et al., 2007). Foi demonstrado que a expressão da proteína LIC101919 é regulada durante a infecção (NALLY et al., 2006) e esta proteína foi reconhecida por soro de animais infectados. Além disso, foi demonstrado ser uma proteína importante na virulência da bactéria, uma vez que quando o gene LIC10191 foi deletado, a bactéria perdeu a capacidade de determinar a morte em cobaias (RISTOW et al., 2007). Em nossos experimentos mostramos que a LIC10191 é antigênica, sendo reconhecida nos estágios iniciais de leptospirose.

A proteína LIC11227 foi reconhecida pelo soro de paciente em intensidade semelhante ao reconhecimento da Lip32 e da HlyX nos ensaios de western blot para detectar IgG e IgM específicos, mostrando-se, portanto, boa candidata para testes de diagnóstico. Uma característica desfavorável é o fato da LIC11227 recombinante ser expressa na forma insolúvel, formando corpúsculos de inclusão. A proteína tornou-se solúvel apenas na presença do agente desnaturante uréia em alta concentração, voltando à forma insolúvel nas nossas tentativas de renaturação por diálise.

A proteína LIC12302 não foi reconhecida pelo soro de paciente em nenhum ensaio de western blot. Também encontramos dificuldade na purificação desta proteína uma vez que é expressa na forma insolúvel e ficava solúvel apenas na presença de alta concentração de uréia.

A utilização de qualquer proteína para diagnóstico por sorologia requererá melhor avaliação quanto aos aspectos relativos a facilidade de produção, antigenicidade e ainda a cronologia de indução de anticorpos durante a infecção através de testes com soros de pacientes em diferentes estágios da doença.

Nos ensaios de imunização de camundongos testamos a administração das salmonelas recombinantes por três vias distintas, intraperitoneal, intranasal e oral, além das proteínas purificadas administradas por via intraperitoneal. Sempre as imunizações com as proteínas purificadas induziram mais anticorpos IgG do que as salmonelas apresentando os antígenos, provavelmente relacionado com a menor quantidade do antígeno expresso na salmonela.

Nos nossos protocolos de imunização com salmonelas, as vias intraperitoneal e intranasal mostraram níveis de anticorpos IgG parecidos; níveis baixos, porém mais altos que o induzido por via oral. A imunização por via oral somente em alguns casos apresentou tênues 
resultados, e em geral não afetou a sistema imune em relação a indução de anticorpos específicos, o que provavelmente está relacionado com baixo número de bactérias atravessando o trato digestivo e ainda menor número invadindo o organismo do animal pelas células da parede do intestino. Entretanto, é descrito na literatura que a administração de bactérias atenuadas por via oral é mais eficiente em induzir resposta secretória, com a produção de IgA, do que a via parenteral. Este tipo de resposta é importante contra organismos que colonizam superfícies mucosas (CÁRDENAS e CLEMENTS, 1992).

Em ensaios feitos anteriormente em nosso laboratório, salmonelas carregando o gene do fragmento $\mathrm{C}$ da toxina tetânica sob controle de expressão do promotor soxS foram usadas na imunização de camundongos. Os resultados mostraram que a bactéria foi capaz de apresentar o antígeno in vivo e induzir resposta imune de maneira que os animais se tornaram protegidos e sobreviveram ao desafio com a toxina tetânica, mesmo que apresentassem baixos títulos de IgG anti-toxina nas dosagens por ELISA em comparação com a resposta à proteína purificada (TOMITA, 2005). Em outro ensaio descrito na literatura, duas doses via oral ou via intravenosa de salmonela da linhagem SL3261 carregando o fragmento C da toxina tetânica também protegeu 100\% dos animais desafiados com a toxina (FAIRWEATHER et al.,1990).

A utilização de salmonelas recombinantes também resultou em proteção em testes com PspA de Streptococcus pneumonie (XIN et al., 2009), antígenos F1 e V de Yersinia pestis (TITBALL et al., 1997; GARMORY et al., 2003), antígeno O de Pseudomonas aeruginosa (DiGIANDOMENICO et al., 2004), proteína de circumsporozoito de malaria (SADOFF et al., 1988), indicando que a salmonela é capaz de apresentar os antígenos e afetar o sistema imune do hospedeiro. Nesses ensaios outros promotores de expressão foram usados. De fato, foi comprovado que a salmonela é capaz de induzir resposta imune completa, humoral e secretória, gerando anticorpos IgA e IgG, além de resposta celular mediada por linfócitos Th1, com a produção de IL-2, IFN- $\gamma$ e anticorpos do tipo IgG2a (HORMAECHE et al., 1991; VILLARREAL et al., 1992; HARRISON et al., 1997).

Nossos ensaios corroboraram os dados da literatura, mais uma vez validando as salmonelas vivas atenuadas como interessante vetor vacinal. Além disso, ficou comprovada a capacidade e eficácia do sistema controlador de expressão soxRS em controlar a expressão dos antígenos de leptospira in vitro e in vivo.

Nossos ensaios acrescentam valor a estratégia do uso de salmonelas recombinantes como vetor vacinal com o vetor pAEsox e, ainda mais, a possibilidade de apresentação de mais de um antígeno pelo mesmo microrganismo recombinante. Não foi possível relacionar títulos de IgG após as imunizações com as salmonelas com os níveis de expressão das 
proteínas in vitro, mas acreditamos que a administração de dois antígenos simultaneamente aumentaria a resposta, como foi visto com antígenos purificados OmpL1 e LipL41 (HAAKE et al., 1999), LigA e LigB (KOIZUME e WATANABE, 2004). A proposta de construção dos plasmídeos híbridos, carregando genes de dois antígenos para expressão simultânea mostrouse uma boa estratégia para aumentar a resposta imune contra leptospiras, sem aumentar a dose de salmonela administrada. Além disso, estabelece a possibilidade de aumentar a resposta contra um antígeno clonando o mesmo gene em tandem para aumentar a expressão in vivo.

Quatro antígenos foram selecionados para clonagem de forma combinada em construções de plasmídeos híbridos: a LIC10191, pelo bom resultado no primeiro ensaio de imunização e desafio, a LIC10793, apresentada na literatura como interessante para diagnóstico devido sua imunogenicidade (NEVES et al., 2007), a LIC10537 que possui domínio OmpA, semelhante à LIC10191, e que protegeu 28\% dos animais imunizados quando expresso pela salmonela (FRAGA et al., 2009) e a Lip32 descrita como a proteína mais abundante na membrana da bactéria (HAAKE et al., 2000). Os plasmídeos pAEsoxLIC10191_LIC10793 e pAEsoxLIC10191_LIC10537 foram testados em E. coli com sucesso. No teste de indução desses plasmideos em salmonela in vitro não conseguimos identificar a banda da proteína LIC10537 de 76 kDa. O plasmídeo pAEsoxLIC10191_Lip32 também foi testado com sucesso na indução in vitro da salmonela.

A imunização de camundongos com salmonela carregando o plasmideo hibrido com os genes LIC10191 e LIC10537 induziu títulos IgG anti-LIC10191 mais altos do que no grupo imunizado com salmonela carregando apenas o gene LIC10191. Esses dois antígenos possuem domínio OmpA, com 39\% de similaridade entre eles. Possivelmente algum epitopo comum tenha apresentado efeito de "booster". Como sempre tem ocorrido, a imunização com as proteínas purificadas elevou mais os níveis de anticorpos IgG específico, comparando com a imunização com salmonelas.

O ensaio de imunização de camundongos com a salmonela carregando as proteínas LIC10191 e LIC10537 foi interessante, elevando os níveis de IgG anti-LIC10191. No entanto tívemos dificuldades na purificação da proteína LIC10537 para as imunizações e testes de ELISA e western blot. De fato, a proteína LIC10537 foi expressa na forma de corpúsculo de inclusão e foi purificada na presença de agentes desnaturantes, sendo a renaturação feita por alta pressão hidrostática, resultando em baixa recuperação final (FRAGA et al., 2010). Por isso, o ensaio com clone carregando a LIC10537 foi adiado e nos ensaios de imunização e desafio de hamsters foi priorizado o trabalho com os clones de salmonela apresentando as duplas LIC10191_LIC10793 e LIC10191_Lip32. 
Ensaios de imunização e desafio com leptospiras virulentas descritos na literatura são realizados com gerbils, cobaias, camundongos C3H/HeJ e hamsters (LEWIS e GRAY, 1961; da SILVA et al.,1995; HAAKE et al., 1999; NALLY et al., 2004; SILVA et al., 2008; Da SILVA et al., 2009), uma vez que camundongos e ratos são geralmente resistentes a infecção. Um dos primeiros ensaios de infecção experimental com leptospira foi descrito por RANDALL e COOPER (1944). Neste trabalho hamsters foram infectados com Leptospira canicola e Leptospira icterohaemorrhagiae isoladas de pacientes e morreram em decorrência da infecção, provando ser um bom modelo para ensaios de desafio com leptospiras.

Nos ensaios de imunização e desafio utilizamos hamsters machos. Realizamos um teste prévio com $3 \times 10^{7}$ salmonela carregando o gene de fragmento $\mathrm{C}$ da toxina tetânica para avaliar a susceptibilidade dos hamsters a esta bactéria. Observamos que esses animais parecem mais resistentes do que os camundongos a toxicidade das salmonelas, tendo recebido três doses e não apresentando nenhum sintoma de infecção, como febre ou diarréias. Após novos testes determinamos a dose 3 a $5 \times 10^{7}$ salmonelas por animal, para os ensaios com hamsters.

O primeiro ensaio de imunização e desafio mostrou que salmonela apresentando LIC10191 foi capaz de induzir resposta imune protetora em hamsters, sendo que sobreviveram quatro animais dentre nove desafiados (44\%), frente a $10 \%$ de sobrevivência nos controles. Os testes de western blot confirmaram a expressão da proteína in vivo pela salmonela. Apenas um desses animais sobreviventes teve resultado positivo no crescimento das bactérias do macerado do rim. Os resultados de sobrevivência da curva de dose desse ensaio e dos grupos controle e grupo imunizado com a proteína purificada validaram o dado de proteção pela salmonela recombinante como significativo. O resultado de proteção é ainda mais significativo uma vez que muitos antígenos, descritos na literatura conferem proteção parcial, porém não impedem a colonização dos rins pela bactéria (SILVA et al., 2007; ATZIGEN et al., 2010; YAN et al., 2010; HAAKE et al., 1999; BRANGER et al., 2005).

Um dado interessante verificado foi um aumento nos níveis de IgG anti-LIC10191 no soro dos animais do grupo SLLIC10191 sobreviventes ao desafio, por testes de ELISA, indicando que a proteína foi apresentada durante a infecção por leptospira. $\mathrm{O}$ mesmo não se verificou com outras proteinas indicando que não se tratava da continua apresentação do antígeno por salmonelas, mas confirmando a imunogenicidade e a antigenicidade da proteína.

Uma dificuldade observada nos ensaios de desafio foi a determinação da $\mathrm{DL}_{50}$. O erro na contagem das leptospiras deve-se ao fato da bactéria ser muito pequena e móvel, dificultando a visualização ao microscópio. Em ensaios descritos na literatura, bactérias da 
linhagem Leptospira interrogans sorovar Pomona são contadas em microscópio de campo escuro, após algumas passagens em cultura, chegando a $\mathrm{DL}_{50}$ de $10^{8}$ bactérias por animal (PALANIAPPAN et al., 2005; FAISAL et al., 2007). Nesses ensaios, a grande quantidade de bactérias inoculadas não foi suficiente para matar todos os animais do grupo controle. Em nossos ensaios verificamos que a L. interrogans sorovar Pomona é visível ao microscópio (aumento 1000x campo escuro) e contável nos extratos dos macerados de fígado dos animais infectados. Ainda assim comprovamos um erro de 1000 vezes na contagem das bactérias.

Existe também variação morfológica e fisiológica entre as linhagens de leptospiras, mesmo pertencendo a mesma espécie. Bactérias do sorovar Pomona são visíveis ao microscópio após o isolamento a partir do fígado de animal infectado, ao contrário das bactérias do sorovar Copenhageni, que necessitam de passagens em cultura para a contagem ao microscópio. O desafio com bactérias do sorovar Pomona foi padronizado pelo grupo colaborador do Dr. Silvio Arruda Vasconcellos. Para a introdução da linhagem do sorovar Copenhageni nos testes de desafio foram realizados vários testes para adequação da dose. Demos preferência para esta linhagem nos nossos ensaios por acreditar que o desafio homólogo seria mais eficiente na detecção de antígenos protetores, uma vez que selecionamos genes da Leptospira interrogans sorovar Copenhageni.

A Leptospira interrogans sorovar Copenhageni quando extraída do macerado do fígado de um animal infectado tende a ser bastante virulenta e a inoculação de apenas algumas bactérias pode causar a morte do animal. Devido à dificuldade de contagem das leptospiras diretamente do macerado do fígado de animal infectado e da alta virulência das leptospiras recém isoladas, optamos por realizar passagens em cultura. Segundo SILVA et al. (2008), as passagens em cultura diminuem a virulência da bactéria, requerendo maior dose e atrasando a morte dos animais. As bactérias do sorovar Copenhageni precisam ser cultivadas e, portanto, expostas ao meio e ao soro de coelho do meio de cultivo, sendo observada grande variabilidade na virulência. De fato, existem trabalhos descrevendo o estabelecimento de meios de cultivo sem soro e formas de manutenção de amostras congeladas, com protocolos que alternam congelamento e passagens em animais (SILVA et al., 2008). O objetivo de usar bactérias com passagens em cultura era diminuir o erro da contagem, administrando dose maior. Para confirmar a contagem das leptospiras em lâmina, realizamos também a contagem na câmara de Petroff-Hausser. A câmara de Petroff-Hausser permite maior precisão na contagem, resultando em geral em aproximadamente 4 vezes mais bactérias do que a contagem na lâmina comum. No ensaio em que utilizamos cultura de segunda passagem, todos os animais morreram no grupo que recebeu a maior dose e três dos cinco animais 
sobreviveram em cada um dos grupos de menor dose. A taxa de sobrevivência nesses grupos indicou que o cultivo em duas passagens reduziu bastante a virulência da bactéria, diferente do que foi observado em experimento anterior do laboratório, no qual, culturas de quatro passagens de L. interogans sorovar Copenhageni ainda apresentavam alta virulência, matando mais de $50 \%$ dos animais mesmo em diluição $1: 10^{6}$. Bactérias cultivadas in vitro expressam diferentes proteínas quando comparadas a bactérias isoladas de um animal (HAAKE et al., 1991), além disso, variações na temperatura, osmolaridade e concentração de soro no meio de cultivo regulam a expressão das proteínas de forma que a bactéria consiga sobreviver no ambiente em que se encontra (PATARAKUL et al., 2010). Fatores de virulência como algumas hemolisinas são secretadas para o meio de cultura durante o crescimento bacteriano (ZHANG et al., 2005). Propusemos um ensaio para testar a influência do meio de cultura no qual a bactéria cresceu na preparação do inóculo para desafio. Neste ensaio não observamos diferenças nos dias de morte dos animais quando injetamos bactérias diluídas em meio fresco ou em meio condicionado, sendo que todos os animais morreram de forma homogênea entre 6 e 11 dias. Além disso, não observamos diferença de susceptibilidade entre animais machos e fêmeas, diferente do trabalho descrito por Silva et al. (2008), no qual animais machos se mostraram mais sensíveis á infecção, como determinado pela $\mathrm{DL}_{50}$ mais baixa.

No primeiro ensaio de imunização e desafio com a Leptospira interrogans sorovar Copenhageni grupos de animais foram imunizados com as proteínas LIC10191, LIC10793 e Lip32 purificadas, salmonelas recombinantes carregando cada uma das proteínas, e os grupos controle vacina comercial, salina ou nada. Os animais foram desafiados com a cultura pura de primeira passagem e não houve sobreviventes nos grupos experimentais, exceto um animal no grupo imunizado com SLLip32. Esse resultado pode ainda ser um resultado significativo considerando a alta dose de leptospiras virulentas no desafio. Analisando as freqüências de mortes relativas às doses de leptospiras, calculamos que a dose ideal para o desafio com essa cultura teria sido uma diluição 1:10 da cultura pura, o que resultaria em $10^{6}$ bactérias contadas em câmara de Petroff-Hausser.

No segundo ensaio de imunização e desafio utilizamos as proteínas mais promissoras estudadas em nosso laboratório e dentre as descritas na literatura, LIC10191, Lip32, LigA e ankB. Todos os antígenos foram clonados em salmonela. Além disso, testamos a salmonela carregando plasmídeo híbrido para expressão de dois antígenos LIC10191_Lip32. Observamos que as proteínas Lip32, LigA e ankB são bastante imunogênicas induzindo altos títulos de IgG. As salmonelas recombinantes foram capazes de expressar essas proteínas in vivo, induzindo anticorpos específicos. Porém, não pudemos determinar se a indução de 
anticorpos seria suficiente para proteger os animais uma vez que o desafio,não foi adequado. Neste ensaio tivemos dificuldade no isolamento das leptospiras do macerado do fígado de um animal infectado. O desafio dos animais imunizados foi adiado, o que nos levou a administrar uma terceira dose de imunógeno que não estava prevista no programa de imunização. $O$ desafio foi realizado com uma cultura pura de segunda passagem e os animais, mesmo de grupos controle, não morreram em decorrência da infecção.

Os ensaios de desafio indicam que vários parâmetros são de difícil controle:

- as linhagens de leptospiras patogênicas isoladas do hamster para o desafio podem apresentar grande variação de virulência; entre sorovares Pomona e Copenhageni notamos variações de tamanho e quantidade de bactérias quando o animal apresenta sintomas de leptospirose.

- cultivos das leptospiras isoladas resultam em perda de virulência, mas não de forma linear;

- a virulência das culturas reflete porcentagem e freqüência de morte dos animais;

- a espécie e a idade do animal desafiado afetam a resposta. Segundo Silva et al. (2008) o sexo do animal também está relacionado com a susceptibilidade a infecção.

Os parâmetros acima ilustram a dificuldade de calcular a dose de desafio e como a padronização deve ser feita para cada cepa utilizada devido a variabilidade da virulência. Em nossos ensaios, a Leptospira interrogans sorovar Pomona mostrou-se mais reprodutivo que o sorovar Copenhageni, porém, o desafio com o sorovar Pomona é sempre realizado diretamente com diluições do macerado do rim de animal infectado, sem passagens em cultura. 


\section{CONCLUSÕES}

- O reconhecimento das proteínas pelos anticorpos IgG e IgM do soro de um paciente infectado por leptospira é um dado importante e indicou alguns possíveis candidatos vacinais. As proteínas antigênicas merecem atenção especial a despeito das dificuldades de expressão e purificação.

- As imunizações com as salmonelas recombinantes foram interessantes mesmo quando administrada pela via oral. Apesar dos baixos títulos de IgG induzidos, sabe-se que as salmonelas apresentam um papel modulador nas vacinas, promovendo resposta imune celular, de interesse contra vários patógenos. Estudos para melhoramento da imunização com salmonelas carregando antígenos de leptospira por via oral estão em sendo propostos no laboratório com o objetivo de aumentar a resposta imune secretória, talvez importante na defesa contra colonização da mucosa renal.

- A utilização de salmonelas como vetor vacinal para humanos é uma estratégia viável, uma vez que existe no mercado uma linhagem de Salmonella Typhi vacinal segura utilizada contra febre tifóide em casos emergenciais. Essa linhagem vacinal poderia ser utilizada como vetor vacinal recombinante contra outros patógenos.

- O sistema regulador soxRS se mostrou bastante interessante e eficiente in vitro e in vivo. O sistema salmonelas com o vetor pAEsox hibrido foi capaz de induzir a expressão de dois antígenos simultaneamente. Outra estratégia em investigação em nosso laboratório para aumentar a resposta contra os antígenos é a atenuação da salmonela pela deleção do gene $m s b B$ que afeta a síntese de lipídeo A, para diminuir a toxicidade da bactéria e permitir o aumento da dose.

- Outro experimento em andamento no laboratório é a comparação da eficiência do promotor soxS com o promotor nirB, bastante citado na na literatura. Clonamos o gene da proteína fluorescente GFP sob o controle desses dois promotores para avaliarmos e compararmos a indução de expressão da proteína in vivo medindo a fluorescência. Esse ensaio foi elaborado para enriquecer o manuscrito descritivo do sistema soxRS como controlados da expressão de genes heterólogos em salmonelas in vivo.

- Observamos que a salmonela recombinante carregando o gene LIC10191 promoveu proteção parcial dos animas desafiados com Leptospira interrogans sorovar Pomona, indicando ser um bom candidato vacinal. 
- Nossos ensaios de desafio com a Leptospira interrogans sorovar Copenhageni não foram conclusivos, e não pudemos confirmar se os antígenos escolhidos são capazes de induzir resposta protetora como proteínas purificadas ou quando expressos pela salmonela. A reprodução do ensaio de imunização e desafio está sendo preparada.

- De maneira geral, a contribuição deste trabalho ocorre especialmente nas dificuldades dos ensaios de desafio. Há que se considerar que as curvas de dose feitas sempre em paralelo nos ensaios de desafio permitiram qualificar o ensaio como valido ou não. As causas das falhas dos ensaios de desafio puderam ser encontradas e um ensaio modelo pode ser desenhado. Resumidamente, o ensaio de imunização e desafio deveria ser iniciado com animais com 40 dias, recebendo duas doses de imunógenos em intervalo de 20 dias. O desafio com Leptospira interrogans sorovar Copenhageni seria com $10^{6}$ bactérias de um cultivo de primeira passagem, dez dias após isolamento do fígado de animal infectado experimentalmente. Embora o desenho experimental do desafio tenha sido possível, o controle dos muitos parâmetros relacionados nem sempre foi possível em nossos ensaios.

O desafio com o sorovar Pomona está mais bem estabelecido e os parâmetros são mais reprodutivos. A possibilidade de contagem das bactérias do sorovar Pomona no macerado de fígado permite inóculo para desafio diretamente de diuições do extrato do fígado, enquanto as bactérias do sorovar Copenhageni precisam ser cultivadas. Devido a grande variabilidade na virulência, seria recomendado o desafio com cultivos de somente uma passagem. Entre os pesquisadores do Butantan que trabalham no desenvolvimento de vacinas contra leptospirose e em nosso grupo muito tem sido feito para compreender os parâmetros que regem a manutenção da virulência das leptospiras no cultivo. Ainda há que se considerar a dificuldade intrínseca de isolamento das leptopiras do animal que apresenta fortes sintomas da doença o que implica em possível septicemia, e no isolamento, o cultivo não pode ser contaminado por outras bactérias.

Nossos estudos levaram ao estabelecimento dos clones dos principais antígenos de leptospira, tanto clones para purificação de proteinas quanto clones em salmonelas vacinais prontos para um ensaio de imunização e desafio. No ensaio previsto para breve, além de aplicação dos paramentros já estabelecidos também observaremos o protocolo de segurança, por isolamento de bactérias e preparo de cultivos a partir de maior numero de animais para garantir disponibilidade de culturas adequadas no momento do desafio. 


\section{REFERÊNCIAS*}

ADLER, B.; FAINE, S.; CHRISTOPHER, W. L.; CHAPPEL, R. J. Development of an improved selective medium for isolation of leptospires from clinical material. Veterinary Microbiology, v. 12, p. 377-381, 1986.

AMÁBILE-CUEVAS, C. F.; DEMPLE, B. Molecular characterization of the soxRS genes of Escherichia coli: two genes control a superoxide stress regulon. Nucleic Acids Res., v. 25, n. 19, p. 4479-4484, 1991.

ATZINGEN, M. V.; GONÇALES, A. P.; MORAIS, Z. M.; ARAÚJO, E. R.; DE BRITO, T.; VASCONCELLOS, S. A.; NASCIMENTO, A. L. T. O. Characterization of leptospiral proteins that afford partial protection in hamsters against lethal challenge with Leptospira interrogans. Journal of Medical Microbiology, v. 59, p. 1005-1015, 2010.

BAL, A. E.; GRAVEKAMP, C.; HARTSKEERL, R. A.; MEZA-BREWSTER, J. D. E.; KORVER, H.; TERPSTRA, W. J. Detection of Leptospires in Urine by PCR for Early Diagnosis of Leptospirosis. Journal of Clinical Microbiology, v. 32, n. 8, p. 1894-1898, 1994.

BARBOSA, A. S.; ABREU, P. A.; NEVES, F. O.; ATZINGEN, M. V.; WATANABE, M. M.; VIEIRA, M. L.; MORAIS, Z. M.; VASCONCELLOS,, S. A.; NASCIMENTO, A. L. A newly identified leptospiral adhesin mediates attachment to laminin. Infect. Immun., v. 74, n. 11, p. 6356-6364, 2006.

BARGIERI, D.Y.; LEITE, J. A.; LOPES, S. C.; SBROGIO-ALMEIDA, M. E.; BRAGA, C. J.; FERREIRA, L. C.; SOARES, I. S.; COSTA, F. T.; RODRIGUES, M. M. .Immunogenic properties of a recombinant fusion protein containing the C-terminal $19 \mathrm{kDa}$ of Plasmodium falciparum merozoite surface protein-1 and the innate immunity agonist FliC flagellin of Salmonella typhimurium. Vaccine, v. 28, n. 16, p. 2818-2826, 2010.

BARNETT, J. K.; BARNET, D.; BOLIN, C. A.; SUMMERS, T. A.; WAGAR, E. A.; CHEVILLE, N. F.; HARTSKEERL, R. A.; HAAKE, D. A. Expression and distribution of leptospiral outer membrane components during renal infection of hamsters. Infect. Immun., v. 67 , n. 2, p. 853-861, 1999.

BEUKEN, E; VINK, C.; BRUGGEMAN, C. A. One-step procedure for screening recombinant plasmids by size. Biotechniques, v. 24, p. 749-750, 1998.

*De acordo com: ASSOCIAÇÃO BRASILEIRA DE NORMAS TÉCNICAS. NBR 6023: Informação e documentação: referências: elaboração. Rio de Janeiro, 2002. 
BHARTI, A. R.; NALLY, J. E.; RICALDI, J. N.; MATTHIAS, M. A.; DIAZ, M. M.; LOVETT, M. A.; LEVETT, P. N.; GILMAN, R. H.; WILlIG, M. R.; GOTUZZO, E.; VINETZ, J. M. Leptospirosis: a zoonotic disease of global importance. Lancet Infect. Dis., v. 3, p. 757-771, 2003.

BOLIN, C. A.; ALT, D. P. Use of a monovalent leptospiral vaccine to prevent renal colonization and urinary shedding in cattle exposed to Leptospira borgpetersenii serovar hardjo. Am. J. Vet. Res., v. 62, n. 7, p. 995-1000, 2001.

BOURSAUX-EUDE, C.; SAINT GIRONS, I.; ZUERNER, R. Leptospira genomics. Electrophoresis, v. 19, n. 4, p. 589-592, 1998.

BRADFORD, M. M. A rapid and sensitive method for the quantitation of microgram quantities of protein utilizing the principle of protein-dye biding. Anal. Biochem., v. 72, p. 248-274, 1976.

BRANGER, C.; CHATRENET, B.; GAUVRIT, A.; AVIAT, F.; AUBERT, A.; BACH, J. M.; ANDRE-FONTAINE G,. Protection against Leptospira interrogans sensu lato challenge by DNA immunization with the gene encoding hemolysin-associated protein 1. Infect. Immun., v. 73, n. 7, p. 4062-4069, 2005.

BROWN, A.; HORMAECHE, C. E.; DEMARCO DE HORMAECHE, R.; WINTHER, M.; DOUGAN, G.; MASKELL, D. J.; STOCKER, B. A. An attenuated aroA Salmonella typhimurium vaccine elicits humoral and cellular immunity to cloned beta-galactosidase in mice. J. Infect. Dis., v. 155, n. 1, p. 86-92, 1987.

BROWN, P. D.; GRAVEKAMP, C.; CARRINGTON, D.G.; VAN de, K. H.; HARTSKEERL, R. A.; EDWARDS, C. N.; EVERARD, C. O.; TERPSTRA, W. J.; LEVETT, P. N. Evaluation of the polymerase chain reaction for early diagnosis of leptospirosis. J. Med. Microbiol., v. 43, p. 110-114, 1995.

CABALlERO, O. L.; DIAS NETO, E.; KOURY, M. C.; ROMANHA, A. J.; SIMPSON, A. J. Low-stringency PCR with diagnostically useful primers for identification of Leptospira serovars. J. Clin. Microbiol., v. 32, n. 5, p. 1369-1372, 1994.

CÁRDENAS L.; CLEMENTS J. D. Oral immunization using live attenuated Salmonella spp. as carriers of foreign antigens. Clin. Microbiol. Rev., v. 5, n. 3, p. 328-342, jul. 1992.

CARVALHO, E.; BARBOSA, A. S.; GOMEZ, R. M.; OLIVEIRA, M. L. S.; ROMERO, E. C.; GONÇALES, A. P.; MORAIS, Z. M.; VASCONCELLOS, S. A.; HO, P. L. Evaluation of 
the Expression and Protective Potential of Leptospiral Sphingomyelinases. Curr. Microbiol., v. 60, p. $134-142,2010$.

CHANG, S. L. Studies on Leptospirosis icterohaemorrhagiae IV survival in water and sewage destruction in water by halogen compounds, synthetic detergents and heat. Journal of Infectious Disease, v. 82, p. 256-260, 1948.

CHEN, T. Development and present status of a leptospiral vaccine and the technology of vaccine production in China. Nippon Saikingaku Zasshi, v. 40, p. 755-762, 1985.

CHOY, H. A.; KELLEY, M. M.; CHEN, T. L.; MØLlER, A. K.; MATSUNAGA, J.; HAAKE, D. A. Physiological osmotic induction of Leptospira interrogans adhesion: LigA and LigB bind extracellular matrix proteins and fibrinogen. Infect. Immun., v. 75, n. 5, p. 2441-2450, 2007.

CINCO, M.; CINI, B.; PERTICARARIS \& PRESANI, G. Leptospira interrogans binds to the CR3 receptor on mammalian cells. Microbial Pathogenesis, v. 33, p. 299-305, 2002.

COLE, S. T.; BROSCH, R.; PARKHILL, J.; GARNIER, T.; CHURCHER, C.; HARRIS, D.;

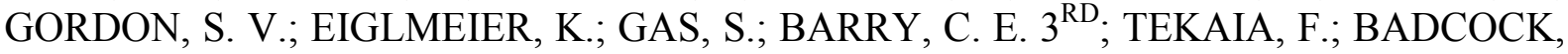
K.; BASHAM, D.; BROWN, D.; CHILLINGWORTH, T.; CONNOR, R.; DAVIES, R.; DEVLIN, K.; FELTWELL, T.; GENTLES, S.; HAMLIN, N.; HOLROYD, S.; HORNSBY, T.; JAGELS, K.; KROGH, A.; MCLEAN, J.; MOULE, S.; MURPHY, L.; OLIVER, K.; OSBORNE, J.; QUAIL, M. A.; RAJANDREAM, M. A.; ROGERS, J.; RUTTER, S.; SEEGER, K.; SKELTON, J.; SQUARES, R.; SQUARES, S.; SULSTON, J. E.; TAYLOR, K.; WHITEHEAD, S.; BARRELL, B. G. Deciphering the biology of Mycobacterium tuberculosis from the complete genome sequence. Nature, v. 393, p. 537-544, 1998.

CULLEN, P. A.; HAAKE, D. A.; BULACH, D. M.; ZUERNER, R. L.; ADLER, B. LipL21 is a novel surface-exposed lipoprotein of pathogenic Leptospira species. Infect. Immun., v. 71, n. 5, p. 2414-2421, 2003.

CULLEN, P. A.; HAAKE, D. A.; ADLER, B. Outer membrane proteins of pathogenic spirochetes. FEMS Microbiol Rev., v. 28, n. 3, p. 291-318, 2004.

DABO, S. M.; CONFER, A. W.; QUIJANO-BLAS, R. A. Molecular and immunological characterization of Pasteurella multocida serotype A:3 OmpA: evidence of its role in P. multocida interaction with extracellular matrix molecules. Microb. Pathog., v. 35, n. 4, p. 147-157, 2003. 
DAINES, D. A.; WU, M. H.; YUAN, S. Y. VapC-1 of nontypeable Haemophilus influenzae is a ribonuclease. J. Bacteriol., v. 189, n. 14, p. 5041-5048, 2007.

DA SILVA, J. B.; RAMOS, T. M.; DE FRANCO, M.; PAIVA, D.; HO, P. L.; MARTINS, E. A.; PEREIRA, M. M. Chemokines expression during Leptospira interrogans serovar Copenhageni infection in resistant BALB/c and susceptible $\mathrm{C} 3 \mathrm{H} / \mathrm{HeJ}$ mice. Microb. Pathog., v. 47, n. 2, p. 87-93, 2009.

DA SILVA, J. J.; NETTO, B. A.; LILEMBAUM, W.; ALVIM, M. E.; DE OLIVEIRA, A.V. The hemorrhagic syndrome of leptospirosis: an experimental study in guinea pigs. Rev. Soc. Bras. Med. Trop., v. 28, n. 3, p. 169-177, 1995.

DEMPLE, B.; HIDALGO, E.; DING, H. Transcriptional regulation via redox-sensitive ironsulphur centres in an oxidative stress response. Biochem. Soc. Symp., v. 64, p. 119-128, 1999.

DEY, S.; MOHAN, C. M.; KUMAR, T. M.; RAMADASS, P.; NAINAR, A. M.; NACHIMUTHU, K. Recombinant LipL32 antigen-based single serum dilution ELISA for detection of canine leptospirosis. Vet. Microbiol., v. 5, n. 103, p. 99-106, 2004.

DiGIANDOMENICO, A.; RAO, J.; GOLDBERG, J. B. Oral vaccination of BALB/c mice with Salmonella enterica serovar Typhimurium expressing Pseudomonas aeruginosa $O$ antigen promotes increased survival in an acute fatal pneumonia model. Infect. Immun., v. 72, n. 12, 7012-7021, 2004.

DOHERTY, T. M.; ANDERSEN, P. Tuberculosis vaccines: development work and future. Curr. Opin. Pulm. Med., v. 6, p. 203-208, 2000.

DOMENECH, V. E. S.; PANTHEL, K.; MEINEL, K. M.; WINTER, S.; RÜSMANN, H. R. Pre-existing anti-Salmonella vector immunity prevents the development of protective antigenspecific CD8 T-cell frequencies against murine listeriosis. Microbes and Infection, v. 9, p. 1447-1453, 2007.

DOMENECH, V. E. S.; PANTHEL, K.; WINTER, S.; RÜSMANN, H. R. Heterologous prime-boost immunizations with different Salmonella serovars for enhanced antigen-specific CD8 T-cell induction. Vaccine, v. 26, p. 1879-1886, 2008.

ELLINGHAUSEN, H. C. Jr.; MCCULLOUGH, W. G. Nutrition of Leptospira pomona and growth of 13 other serotypes: fractionation of oleic albumin complex and a medium of bovine albumin and polysorbate 80. Am. J. Vet. Res., v. 26, p. 45-51, 1965. 
FAINE, S.; ADLER, B.; BOLIN, C.; PEROLAT, P. Leptospira and Leptospirosis. 2nd ed. Melbourne, Australia: MediSci, 1999.

FAIRWEATHER N. F.; CHATFIELD S. N.; MAKOFF A. J.; STRUGNELL R. A.; BESTER J.; MASKELL D. J.; DOUGAN G. Oral vaccination of mice against tetanus by use of a live attenuated Salmonella carrier. Infect. Immun., v. 58, n. 5, p. 1323-1326, maio 1990.

FAISAL, S. M.; YAN, W.; CHEN, C. S.; PALANIAPPAN, R. U.; MCDONOUGH, S. P.; CHANG, Y. F. Evaluation of protective immunity of Leptospira immunoglobulin like protein A (LigA) DNA vaccine against challenge in hamsters. Vaccine, v. 26, n. 2, p. 277-287, 2008.

FARR, R.W. Leptospirosis. Clin. Infect. Dis., v. 21, p. 1-8, 1995.

FLANNERY, B.; COSTA, D.; CARVALHO, F. P.; GUERREIRO, H.; MATSUNAGA, J.; DA SILVA, E. D.; FERREIRA, A. G.; RILEY, L. W.; REIS, M. G.; HAAKE, D. A.; KO, A. I. Evaluation of recombinant Leptospira antigen-based enzyme-linked immunosorbent assays for the serodiagnosis of leptospirosis. J. Clin. Microbiol., v. 39, n. 9, p. 3303-3310, 2001.

FRAGA, T. R. Estudo de potenciais antígenos vacinais de Leptospira interrogans sorovar Copenhageni. 2009. 149 f. Dissertação (Mestrado em Biotecnologia) - Programa de Pósgraduação Interunidades em Biotecnologia, Instituto Butantan, ICB/USP, IPT, São Paulo, 2009.

FRAGA, T. R.; CHURA-CHAMBI, R.M.; GONÇALES, A. P.; MORAIS, Z. M.; VASCONCELlOS, S. A.; MORGANTI, L.; MARTINS, E. A. L. Refolding of the recombinant protein OmpA70 from Leptospira interrogans from inclusion bodies using high hydrostatic pressure and partial characterization of its immunological properties. Journal of Biotechnology, v. 148, p. 156-162, 2010.

GAMBERINI, M.; GOMEZ, R. M.; ATZINGEN, M. V.; MARTINS, E. A. L; VASCONCELLOS, S. A.; ROMERO, E. C.; LEITE, L. C. C.; HO, P. L.; NASCIMENTO, A. L. T. O. Whole-Genome Analysis Of Leptospira Interrogans To Identify Potential Vaccine Candidates Against Leptospirosis. FEMS Microbiol. Lett., v. 244, p. 305-313, 2005.

GARÇON, N.; CHOMEZ, P.; VAN MECHELSEN, M. GlaxoSmithKline adjuvant systems in vaccines: concepts, achievements and perspectives. Expert Rev. Vaccines, v. 6, p. 723-39, 2007.

GARMORY, H. S.; GRIFFIN, K. F.; BROWN, K. A.; TITBALL, R. W. Salmonella vaccines for use in humans: present and future perspectives. Microbiology Reviews, v. 26, p. 339-353, 2002. 
GARMORY, H. S.; GRIFFIN, K. F.; BROWN, K. A.; TITBALL, R. W. Oral immunisation with live aroA attenuated Salmonella enterica serovar Typhimurium expressing the Yersinia pestis V antigen protects mice against plague. Vaccine, v. 21, n. 21-22, p. 3051-3057, 2003.

GIUSEPPE, P. O.; NEVES, F. O.; NASCIMENTO, A. L.; GUIMARÃES, B. G. The leptospiral antigen Lp49 is a two-domain protein with putative protein binding function. $\mathbf{J}$. Struct. Biol., v. 163, n. 1, p. 53-60, 2008.

GUERREIRO, H.; CRODA, J.; FLANNERY, B.; MAZEL, M.; MATSUNAGA, J.; GALVÃO REIS, M.; LEVETT, P. N.; KO, A. I.; HAAKE, D. A. Leptospiral proteins recognized during the humoral immune response to leptospirosis in humans. Infect. Immun., v. 69, p. $4958-4968,2001$.

HAAKE D. A.; WALKER E. M.; BLANCO D. R.; BOLIN C. A.; MILLER M. N.; LOVETT M. A. Changes in the surface of Leptospira interrogans serovar grippotyphosa during in vitro cultivation. Infect. Immun., v. 59, p. 1131-1140, 1991.

HAAKE, D. A.; MAZEL, M. K.; MCCOY, A. M.; MILWARD, F.; CHAO, G.; MATSUNAGA, J.; WAGAR, E. A. Leptospiral outer membrane proteins OmpL1 and LipL41 exhibit synergistic immunoprotection. Infect. Immun., v. 67, n. 12, p. 6572-6582, 1999.

HAAKE, D. A. Spirochaetal lipoproteins and pathogenesis. Microbiology, v. 146, p. 1491$1504,2000$.

HAAKE, D. A.; CHAO, G.; ZUERNER, R. L.; BARNETT, J. K.; BARNETT, D.; MAZEL, M.; MATSUNAGA, J.; LEVETT, P. N.; BOLIN, C. A. The leptospiral major outer membrane protein LipL32 is a lipoprotein expressed during mammalian infection. Infect. Immun., v. 68, p. 2276-2285, 2000.

HAAKE, D. A.; DUNDOO, M.; CADER, R.; KUBAK, B. M.; HARTSKEERL, R. A.; SEJVAR, J. J.; ASHFORD, D. A. Leptospirosis, water sports, and chemoprophylaxis. Clin. Infect. Dis., v. 34, n. 9, p. 40-43, 2002.

HARRISON, J.A.; VILLARREAL-RAMOS, B.; MASTROENI, P.; DEMARCO, D. E. HORMAECHE, R.; HORMAECHE, C. E. Correlates of protection induced by live AroSalmonella typhimurium vaccines in the murine typhoid model. Immunology, v. 90, p. 618625, 1997.

HAUK, P. ; NEGROTTO, S. ; ROMERO, E. C. ; VASCONCELLOS, A. S. ; GENOVEZ, M. E.; WARD, R. J.; SCHATTNER, M.; GOMEZ, R. M.; HO, P. L. Expression and characterization of HlyX hemolysin from Leptospira interrogans serovar Copenhageni: 
potentiation of hemolytic activity by LipL32. Biochem. Biophys. Res. Commun., v. 12, n. 4, p. 1341-1347, 2005.

HOISETH, S. K.; STOCKER, B. A. Aromatic-dependent Salmonella typhimurium are nonvirulent and effective as live vaccines. Nature, v. 5812, p. 238-239, 1981.

HONE, D. M.; TACKET, C. O.; HARRIS, A. M.; KAY, B.; LOSONSKY, G.; LEVINE, M. M. Evaluation in volunteers of a candidate live oral attenuated Salmonella typhi vector vaccine. J. Clin. Invest., v. 90, n. 2, p. 412-420, 1992.

HORMAECHE, C. E.; JOYSEY, H. S.; DE SILVA, L.; IZHAR, M.; STOCKER, B. A. Immunity conferred by Aro Salmonella live vaccines. Microbial Pathogenesis, v. 10, p. 149$158,1991$.

HOTEZ, P. J.; FERRIS, M. T. The antipoverty vaccines. Vaccine, v. 24, p. 5787-5799, 2006

IKOEV, V. N.; GORBUNOV, M. A.; VACHAEV, B. F.; IAGOVKIN, E. A.; KONDRATENKO, V. F.; ANAN'INA, I.; ANSIMOVA, T. I.; KOSTINA, N. I.; IUR'EVA, I. L.; NIKITIN, M. G. The evaluation of the reactogenicity and immunogenic activity of a new concentrated inactivated leptospirosis vaccine. Zhurnal mikrobiologii, epidemiologii, i immunobiologii, v. 4, p. 39-43, 1999.

KANG, H. Y.; SRINIVASAN, J.; CURTISS, R. $3^{\text {RD }}$. Immune responses to recombinant pneumococcal PspA antigen delivered by live attenuated Salmonella enterica serovar typhimurium vaccine. Infect. Immun., v. 70, n. 4, p. 1739-1749, 2002.

KELLY, S. M.; JESS, T. J.; PRICE, N. C. How to study proteins by circular dichroism. Biochim. Biophys. Acta., v. 1751, n. 2, p. 119-139, 2005.

KHAN, S. A.; EVEREST, P.; SERVOS, S.; FOXWELL, N.; ZAHRINGER, U.; BRADE, H.; RIETSCHEL, E. T.; DOUGAN, G.; CHARLES, I. G.; MASKELL, D. J. A lethal role for lipid A in Salmonella infections. Molecular Microbiology, v. 29, p. 571-579, 1998.

KITAOKA, M.; INOUE, S. Standard procedures of Weil's disease vaccine and Weil's disease and Akiyami combined vaccine (Japanese in original). Jpn. Med. J., v. 1478, p. 2845-2847, 1952.

KOPECKO, D. J.; SIEBER, H.; URES, J. A.; FÜRER, A.; SCHLUP, J.; KNOF, U.; COLLIOUD, A.; XU, D.; COLBURN, K.; DIETRICH, G. Genetic stability of vaccine strain 
Salmonella Typhi Ty21a over 25 years. Int. J. Med. Microbiol., v. 299, n. 4, p. 233-246, 2009.

KOIZUMI, N.; WATANABE, H. Molecular cloning and characterization of a novel leptospiral lipoprotein with OmpA domain. FEMS Microbiol. Lett., v. 226, n. 2, p. 215-219, 2003.

KOIZUMI, N; WATANABE, H. Leptospiral immunoglobulin-like proteins elicit protective immunity. Vaccine, v. 29, n. 22, p. 1545-1552, 2004.

KOIZUMI, N.; WATANABE, H. Leptospirosis vaccines: Past, Present, and Future. J. Postgrad. Med., v. 51, p. 210-214, 2005.

LAEMMLI, U. K. Cleavage of structural proteins during assembly of the head of bacteriophage T4. Nature, v. 227, p. 680-685, 1970.

LAGRANDERIE, M.; CHAVAROT, P.; BALAZUC, A. M.; MARCHAL, G. Immunogenicity and protective capacity of Mycobacterium bovis BCG after oral or intragastric administration in mice. Vaccine, v. 18, p. 1186-1195, 2000.

LEVETT, P. N. Leptospirosis. Clin. Microbiol. Rev., v. 14, p. 296-326, 2001.

LEVETT, P. N.; MOREY, R. E.; GALLOWAY, R. L.; TURNER, D. E.; STEIGERWALT, A. G.; MAYER, L. W. Detection of pathogenic leptospires by real-time quantitative PCR. J. Med. Microbiol., v. 54, p. 45-49, 2005.

LEVINE, M. M.; FERRECCIO, C.; BLACK, R. E.; TACKET, C. O.; GERMANIER, R. Progress in vaccines against typhoid fever. Review of Infectious Diseases 11 Suppl 3, S55267, 1989. Journal of Clinical Investigation, v. 97, p. 359-65, 1989.

LEVINE, M. M.; KAPER, J. B. Live oral vaccines against cholera: an update. Vaccine, v. 11, p. 207-212, 1993.

LEWIS, C; GRAY, J. E. Experimental Leptospira pomona infection in the Mongolian gerbil (Meriones unguiculatus). J. Infect. Dis., v. 109, p. 194-204, 1961.

LO, M.; BULACH, D. M.; POWELL, D. R.; HAAKE, D. A.; MATSUNAGA, J.; PAUSTIAN, M. L.; ZUERNER, R. L.; ADLER B. Effects of temperature on gene expression patterns in Leptospira interrogans serovar Lai as assessed by whole-genome microarrays. Infect. Immun., v. 10, p. 5848-5859, 2006. 
LOPES, L. M. Clonagem, expressão e purificação de proteínas candidats vacinais de Leptospira interrogans sorovar Copenhageni. Avaliação de atividades imunogênicas e características funcionais. 2009. 92 f. Dissertação (Mestrado em Biotecnologia) - Programa de Pós-graduação Interunidades em Biotecnologia, Instituto Butantan, ICB/USP, IPT, 2009.

LOW, K. B.; ITTENSOHN, M.; LE, T.; PLATT, J.; SODI, S.; AMOSS, M.; ASH, O.; CARMICHAEL, E.; CHAKRABORTY, A.; FISCHER, J.; LIN, S. L.; LUO, X.; MILLER, S. I.; ZHENG, L.; KING, I.; PAWELEK, J. M.; BERMUDES, D. Lipid A mutant Salmonella with suppressed virulence and TNFalpha induction retain tumor-targeting in vivo. Nat. Biotechnol., v. 17, n. 1, p. 37-41, 1999.

MARTINEZ, S. R.; OBREGON FUENTES, A. M.; PEREZ, S. A.; BALY, G. A.; DIAZ, G. M.; BARO, S. M.; MENENDEZ, C. R.; RUIZ, P. A.; SIERRA, G. G.; LOPEZ CHAVEZ, A. $\mathrm{U}$. The reactogenicity and immunogenicity of the first Cuban vaccine against human leptospirosis. Revista Cubana de Medicina Tropical, v. 50, p. 159-166, 1998.

MARTINEZ, S. R.; PEREZ, S. A.; BARO, S. M.; ALVAREZ, A. M.; MENENDEZ, H. J.; DIAZ, G. M.; CRUZ, D. L. P.; DE LOS, R. G.; MONTOYA, B. B.; SIERRA, G. G.; ARMESTO, D. R.; SALTAREN, C. A.; SABOURNIN, R. O. Evaluation of the effectiveness of a new vaccine against human leptospirosis in groups at risk. Revista Panamericana de Salud Publica, v. 8, p. 385-392, 2000.

McKELVIE, N. D.; KHAN, S. A.; KARAVOLOS, M. H.; BULMER, D. M.; LEE, J. J.; DeMARCO, R.; MASKELL, D. J.; ZAVALA, F.; HORMAECHE, C. E.; KHAN, C. M. Genetic detoxification of an aroA Salmonella enterica serovar Typhimurium vaccine strain does not compromise protection against virulent Salmonella and enhances the immune responses towards a protective malarial antigen. FEMS Immunol. Med. Microbiol., v. 52, n. 2, p. 237-246, 2008.

MILLER, S. I. PhoP/PhoQ: macrophage-specific modulators of Salmonella virulence? Molecular Microbiology, v. 5, p. 2073-2078, 1991.

MINISTÉRIO DA SAÚDE. LEPTOSPIROSE. 2009. Disponível em: http://portal.saude.gov.br/ portal/arquivos/pdf/ apresentacao_ lepto.pdf. Acesso em: 02 jul. 2010.

MINISTÉRIO DA SAÚDE. Gráfico de casos confirmados de Leptospirose. Brasil, Grandes regiões e Unidades Federadas, 2009. 2010. Disponível em: http://portal.saude.gov.br/porta 1/arquivos/pdf/tabela_4_06_07_2010.pdf. Acesso em: 02 jul. 2010 . 
MORGAN, J.; BORNSTEIN, S. L.; KARPATI, A. M.; BRUCE, M.; BOLIN, C. A.; AUSTIN, C. C.; WOODS, C. W.; LINGAPPA, J.; LANGKOP, C.; DAVIS, B.; GRAHAM, D. R.; PROCTOR, M.; ASHFORD, D. A.; BAJANI, M.; BRAGG, S. L.; SHUTT, K.; PERKINS, B. A.; TAPPERO, J. W. Outbreak of leptospirosis among triathlon participants and community residents in Springfield, Illinois, 1998. Clinical Infectious Disease, v. 34, p. 1593-1599, 2002.

NALLY J. E.; CHANTRANUWAT C.; WU X. Y.; FISHBEIN M. C.; PEREIRA M. M.; DA SILVA J. J.; BLANCO D. R.; LOVETT M. A. Alveolar septal deposition of immunoglobulin and complement parallels pulmonary hemorrhage in a guinea pig model of severe pulmonary leptospirosis. Am. J. Pathol., v. 164, n. 3, p. 1115-1127, mar. 2004.

NALLY, J. E.; WHITELEGGE, J. P.; AGUILERA, R.; PEREIRA, M. M.; BLANCO, D. R.; LOVETT, M. A. Purification and proteomic analysis of outer membrane vesicles from a clinical isolate of Leptospira interrogans serovar Copenhageni. Proteomics., v. 5, p. 144$152,2005$.

NASCIMENTO, A. L. T. O.; VERJOVSKI-ALMEIDA, S.; VAN SLUYS, M. A.; MONTEIRO-VITORELLO, C. B.; CAMARGO, L. E. A.; DIGIAMPIETRI, L. A.;

HARSTKEERL, R. A.; HO, P. L.; MARQUES, M. V.; OLIVEIRA, M. C.; SETUBAL, J. C.; HAAKE, D. A.; MARTINS, E. A. L. Genome features of Leptospira interrogans serovar Copenhageni. Braz. J. Med. Biol. Res., v. 37, n. 4, p. 459-477, 2004.

NASCIMENTO, A. L.; KO, A. I.; MARTINS, E. A.; MONTEIRO-VITORELLO, C. B.; HO, P. L.; HAAKE, D. A.; VERJOVSKI-ALMEIDA, S.; HARTSKEERL, R. A.; MARQUES, M. V.; OLIVEIRA, M. C.; MENCK, C. F.; LEITE, L. C.; CARRER, H.; COUTINHO, L. L.; DEGRAVE, W. M.; DELLAGOSTIN, O. A.; EL-DORRY, H.; FERRO, E. S.; FERRO, M. I.; FURLAN, L. R.; GAMBERINI, M.; GIGLIOTI, E. A.; GOES-NETO, A.; GOLDMAN, G. H.; GOLDMAN, M. H.; HARAKAVA, R.; JERONIMO, S. M.; JUNQUEIRA-DEAZEVEDO, I. L.; KIMURA, E. T.; KURAMAE, E. E.; LEMOS, E. G.; LEMOS, M. V.; MARINO, C. L.; NUNES, L. R.; DE OLIVEIRA, R. C.; PEREIRA, G. G.; REIS, M. S.; SCHRIEFER, A.; SIQUEIRA, W. J.; SOMMER, P.; TSAI, S. M.; SIMPSON, A. J.; FERRO, J. A.; CAMARGO, L. E.; KITAJIMA, J. P.; SETUBAL, J. C.; VAN SLUYS, M. A. Comparative genomics of two Leptospira interrogans serovars reveals novel insights into physiology and pathogenesis. J. Bacteriol., v. 186, n. 7, p. 2164-2172, 2004.

NEVES, F. O.; ABREU, P. A. E.; VASCONCELLOS, S. A.; MORAIS, Z. M.; ROMERO, E. C.; NASCIMENTO, A. L. T. O. Identification of a novel potencial antigen for early-phase serodiagnosis of leptospirosis. Arch Microbiol, v. 188, n. 5, p. 523-532, 2007.

NUNOSHIBA, T.; HIDALGO, E.; AMÁBILE CUEVAS, C. F.; DEMPLE, B. Two-stage control of an oxidative stress regulon: the Escherichia coli SoxR protein triggers redoxinducible expression of the soxS regulatory gene. J. Bacteriol., v. 174, n. 19, p. 6054-6060, 1992. 
OLIVEIRA, M. A.; CABALLERO, O. L.; VAGO, A. R.; HARSKEERL, R. A.; ROMANHA, A. J.; PENA, S. D.; SIMPSON, A. J.; KOURY, M. C. Lowstringency single specific primer PCR for identification of Leptospira. Journal of Medical Microbiology, v. 52, p. 127-135, 2003.

PACHECO, L. G.; ZUCCONI, E.; MATI, V. L.; GARCIA, R. M.; MIYOSHI, A.; OLIVEIRA, S. C.; DE MELO, A. L.; AZEVEDO, V. Oral administration of a live Aro attenuated Salmonella vaccine strain expressing 14-kDa Schistosoma mansoni fatty acidbinding protein induced partial protection against experimental schistosomiasis. Acta Trop., v. 95, n. 2, p. 132-142, 2005.

PALANIAPPAN, R. U.; MCDONOUGH, S. P.; DIVERS, T. J.; CHEN, C. S.; PAN, M. J.; MATSUMOTO, M.; CHANG, Y. F. Immunoprotection of recombinant leptospiral immunoglobulinlike protein A against Leptospira interrogans serovar Pomona infection. Infect. Immun., v. 3, p. 1745-1750, 2006.

PATARAKUL, K.; LO, M.; ADLER, B. Global transcriptomic response of Leptospira interrogans serovar Copenhageni upon exposure to serum. BMC Microbiol., v. 29, p. 10-31, jan. 2010.

PEREIRA, M. M. Leptospirose. In: CORRÊA, J. R. Dinâmica das doenças infecciosas e parasitárias. Rio de Janeiro: Guanabara Koogan, 2005. p. 1497-1508.

PICARDEAU, M.; BULACH, D. M.; BOUCHIER, C.; ZUERNER, R. L.; ZIDANE, N.; WILSON, P. J.; CRENO, S.; KUCZEK, E. S.; BOMMEZZADRI, S.; DAVIS, J. C.; MCGRATH, A.; JOHNSON, M. J.; BOURSAUX-EUDE, C.; SEEMANN, T.; ROUY, Z.; COPPEL, R. L.; ROOD, J. I.; LAJUS, A.; DAVIES, J. K.; MÉDIGUE, C.; ADLER, B. Genome sequence of the saprophyte Leptospira biflexa provides insights into the evolution of Leptospira and the pathogenesis of leptospirosis. PLoS One, v. 3, n. 2, p. e1607, 2008.

PIZZA, M.; SCARLATO, V.; MASIGNANI, V.; GIULIANI, M. M.; ARICO, B.; COMANDUCCI, M.; JENNINGS, G. T.; BALDI, L.; BARTOLINI, E.; CAPECCHI, B.; GALEOTTI, C. L.; LUZZI, E.; MANETTI, R.; MARCHETTI, E.; MORA, M.; NUTI, S.; RATTI, G.; SANTINI, L.; SAVINO, S.; SCARSELLI, M.; STORNI, E.; ZUO, P.; BROEKER, M.; HUNDT, E.; KNAPP, B.; BLAIR, E.; MASON, T.; TETTELIN, H.; HOOD, D. W.; JEFFRIES, A. C.; SAUNDERS, N. J.; GRANOFF, D. M.; VENTER, J. C.; MOXON, E. R.; GRANDI, G.; RAPPUOLI, R. Identification of vaccine candidates against serogroup B meningococcus by whole-genome sequencing. Science, v. 287, p. 1816-1820, 2000.

RAMOS, C. R.; ABREU, P. A.; NASCIMENTO, A. L.; HO, P. L. A high-copy T7 Escherichia coli expression vector for the production of recombinant proteins with a minimal N-terminal His-tagged fusion peptide. Braz. J. Med. Biol. Res., v. 37, n. 8, p. 1103-1109, 2004. 
RANDALL, R.; COOPER, H. K. The golden hamster (Cricetus auratus) as a test animal for the diagnosis of leptospirosis. Science. v. 100, n. 2589, p. 133-134, 1944.

RAPPUOLI, R. Reverse vaccinology. Curr. Opin. Microbiol., v. 3, n. 5, p. 445-450. Review, 2000.

REED, L. J.; MUENCH, H. A simple method of estimating fifty percent endpoints. Am. J. Hyg., v. 27, p. 493-497, 1938.

REN, S. X.; FU, G.; JIANG, X. G.; ZENG, R.; MIAO, Y. G.; XU, H.; ZHANG, Y. X.; XIONG, H.; LU, G.; LU, L. F.; JIANG, H. Q.; JIA, J.; TU, Y. F.; JIANG, J. X.; GU, W. Y.; ZHANG, Y. Q.; CAI, Z.; SHENG, H. H.; YIN, H. F.; ZHANG, Y.; ZHU, G. F.; WAN, M.; HUANG, H. L.; QIAN, Z.; WANG, S. Y.; MA, W.; YAO, Z. J.; SHEN, Y.; QIANG, B. Q.; XIA, Q. C.; GUO, X. K.; DANCHIN, A.; SAINT, G. I,; SOMERVILLE, R. L.; WEN, Y. M.; SHI, M. H.; CHEN, Z.; XU, J. G.; ZHAO, G. P. Unique physiological and pathogenic features of Leptospira interrogans revealed by whole genome sequencing. Nature, v. 422, p. 888-893, 2003.

RISTOW, P.; BOURHY, P.; MCBRIDE, F. W.; FIGUEIRA, C. P.; HUERRE, M.; AVE, P.; GIRONS, I. S.; KO, A. I.; PICARDEAU, M. The OmpA-Like protein Loa22 is essential for leptospiral virulence. PLoS Pathog., v. 3, p. 894-903, 2007.

RODRIGUEZ-GONZALEZ, I.; FILLONNEAU, C.; BLANCHET, B.; SUARD, I.; CATILINA, P.; ANDRE-FONTAINE, G. Efficacy of Spirolept vaccine against human leptospirosis as estimated by passive protection of laboratory rodents. Med. Mal. Infect., v. 34, n. 5, p. 196-200, 2004.

ROZENKRANZ, C. D.; CHIARA, D.; AGORIO, C.; BAZ, A.; PASETTI, M. F.; SCHREIBER, F.; DEMATTEIS, S.; MARTINEZ, M.; SZTEIN, M. B.; CHABALGOITY, J. A. Towards new immunotherapies: targeting recombinant cytokines to the immune system using live attenuated Salmonella. Vaccine, v. 21, p. 798-801, 2003.

SADOFF, J. C.; BALLOU, W. R.; BARON, L. S.; MAJARIAN, W. R.; BREY, R. N.; HOCKMEYER, W. T.; YOUNG, J. F.; CRYZ, S. J.; OU, J.; LOWELL, G. H.; et al. Oral Salmonella typhimurium vaccine expressing circumsporozoite protein protects against malaria. Science, v. 240, n. 4850, p. 336-338, abr. 1988.

SAMBROOK, J.; FRITSCH, E. F.; MANIATIS, T. Molecular Cloning a laboratory manual. 2nd ed. New York: Cold Sprong Harbor Laboratory, Press., 1989. 3 v. 
SANCHEZ, J. L.; VASQUEZ, B.; BEGUE, R. E.; MEZA, R.; CASTELLARES, G.; CABEZAS, C.; WATTS, D. M.; SVENNERHOLM, A. M.; SADOFF, J. C.; TAYLOR, D. N. Protective efficacy of oral whole-cell/recombinant-B-subunit cholera vaccine in Peruvian military recruits. Lancet., v. 344, n. 8932, p. 1273-1276, 1994.

SBROGIO-ALMEIDA, M. E.; MOSCA, T.; MASSIS, L. M.; ABRAHAMSOHN, I. A., FERREIRA, L. C. S. Host and bacterial factors affecting induction of immune responses to flagelin expressed by attenuated Salmonella vaccine strains. Infect. Immun., v. 72, p. 25462555, 2004.

SILVA, J. F. P. Leptospirose. Revista Acadêmica de Medicina, v. 3, p. 39-44, 1998.

SILVA, E. F.; MEDEIROS, M. A.; MCBRIDE, A. J.; MATSUNAGA, J.; ESTEVES, G. S.; RAMOS, J. G.; SANTOS, C. S.; CRODA, J.; HOMMA, A.; DELlAGOSTIN, O. A.; HAAKE, D. A.; REIS, M. G.; KO, A. I. The terminal portion of leptospiral immunoglobulinlike protein LigA confers protective immunity against lethal infection in the hamster model of leptospirosis. Vaccine, v. 25, n. 33, p. 6277-6286, 2007.

SILVA, E. F.; SANTOS, C. S.; ATHANAZIO, D. A.; SEYFFERT, N.; SEIXAS, F. K.; CERQUEIRA, G. M.; FAGUNDES, M. Q.; BROD, C. S.; REIS, M. G.; DELLAGOSTIN, O. A.; KO, A. I. Characterization of virulence of Leptospira isolates in a hamster model. Vaccine, v. 26, n. 31, p. 3892-3896, 2008.

SOMERVILLE, J. E.; CASSIANO, L.; BAINBRIDGE, B.; CUNNINGHAM, M. D.; DARVEAU, R. P. A novel Escherichia coli lipid A mutant that produced an antiinflammatory lipopolysaccharide. J. Clin. Investig., v. 97, p. 359-365, 1996.

SPRENG, S.; DIETRICH, G.; WEIDINGER, G. Rational design of Salmonella-based vaccination strategies. Methods., v. 38, n. 2, p. 133-143, 2006.

SUTHERLAND, D. R.; ABDULLAH, K. M.; CYOPICK, P.; MELLORS, A. Cleavage of the cell-surface O-sialoglycoproteins CD34, CD43, CD44, and CD45 by a novel glycoprotease from Pasteurella haemolytica. J. Immunol., v. 148, n. 5, p. 1458-1464, 1992.

TAGLIABUE, A.; RAPPUOLI, R. Vacine adjuvants. The dream becomes real. Human Vaccines, v. 4, n. 5, p. 347-349, 2008.

TETTELIN, H.; SAUNDERS, N. J.; HEIDELBERG, J.; JEFFRIES, A. C.; NELSON, K. E.; EISEN, J. A.; KETCHUM, K. A.; HOOD, D. W.; PEDEN, J. F.; DODSON, R. J.; NELSON, W.C.; GWINN, M. L.; DEBOY, R.; PETERSON, J. D.; HICKEY, E. K.; HAFT, D. H.; SALZBERG, S. L.; WHITE, O.; FLEISCHMANN, R. D.; DOUGHERTY, B. A.; MASON, 
T.; CIECKO, A.; PARKSEY, D. S.; BLAIR, E.; CITTONE, H.; CLARK, E. B.; COTTON, M. D.; UTTERBACK, T. R.; KHOURI, H.; QIN, H.; VAMATHEVAN, J.; GILL, J.; SCARLATO, V.; MASIGNANI, V.; PIZZA, M.; GRANDI, G.; SUN, L.; SMITH, H. O.; FRASER, C. M.; MOXON, E. R.; RAPPUOLI, R.; VENTER, J. C. Complete genome sequence of Neisseria meningitidis serogroup B strain MC58. Science, v. 287, p. 1809-1815, 2000.

TITBALL, R. W.; HOWELLS, A. M.; OYSTON, P. C.; WILLIAMSON, E. D. Expression of the Yersinia pestis capsular antigen (F1 antigen) on the surface of an aroA mutant of Salmonella typhimurium induces high levels of protection against plague. Infect. Immun., v. 65, n. 5, p. 1926-1930, 1997.

TOMITA, E. Y. Construção de linhagens recombinantes de salmonelas atenuadas a serem utilizadas como vetor vivo, expressando antígenos heterólogos para imunização via oral e nasal. 2005. $107 \mathrm{f}$. Tese (Doutorado em Biotecnologia) - Programa de Pósgraduação Interunidades em Biotecnologia, Instituto Butantan, ICB/USP, IPT, São Paulo, 2005.

VERJOVSKI-ALMEIDA, S.; DEMARCO, R.; MARTINS, E. A.; GUIMARÃES, P. E.; OJOPI, E. P.; PAQUOLA, A. C.; PIAZZA, J. P.; NISHIYAMA MY, J. R.; KITAJIMA, J. P.; ADAMSON, R. E.; ASHTON, P. D.; BONALDO, M. F.; COULSON, P. S.; DILLON, G. P.; FARIAS, L. P.; GREGORIO, S. P.; HO, P. L.; LEITE, R. A.; MALAQUIAS, L. C.; MARQUES, R. C.; MIYASATO, P. A.; NASCIMENTO, A. L.; OHLWEILER, F. P.; REIS, E. M.; RIBEIRO, M. A.; AS, R. G.; STUKART, G. C.; SOARES, M. B.; GARGIONI, C.; KAWANO, T.; RODRIGUES, V.; MADEIRA, A. M.; WILSON, R. A.; MENCK, C. F.; SETUBAL, J. C.; LEITE, L. C.; DIAS-NETO, E. Transcriptome analysis of the acoelomate human parasite Schistosoma mansoni. Nat. Genet., v. 35, n. 2, p. 148-157, 2003.

VILlARREAL, B.; MASTROENI, P.; De HORMAECHE, R. D.; HORMAECHE, C. E. Proliferative and T-cell specific interleukin (IL-2/IL-4) production responses in spleen cells from mice vaccinated with aroA live attenuated Salmonella vaccines. Microbial Pathogenesis, v. 13, p. 305-315, 1992.

VINDURAMPULLE, C. J.; ATTRIDGE, S. R. Impact of Vector Priming on the Immunogenicity of Recombinant Salmonella Vaccines. Infection and Immunity, v. 71, p. 287-297, 2003.

WEYANT, R. S.; BRAGG, S. L.; KAUFMAN, A. F.. Leptospira and Leptonema, p. 739745. In: MURRAY, P. R.; BARON, E. J.; PFALLER, M. A.; TENOVER, F. C.; YOLKEN, R. H. Manual of clinical microbiology. 7th ed. Washington D.C: ASM Press, 1999. p. 739735. 
WIZEMANN, T. M.; HEINRICHS, J. H.; ADAMOU, J. E.; ERWIN, A. L.; KUNSCH, C.; CHOI, G. H.; BARASH, S. C.; ROSEN, C. A.; MASURE, H. R.; TUOMANEN, E.; GAYLE, A.; BREWAH, Y. A.; WALSH, W.; BARREN, P.; LATHIGRA, R.; HANSON, M.; LANGERMANN, S.; JOHNSON, S.; KOENIG, S. Use of a whole genome approach to identify vaccine molecules affording protection against Streptococcus pneumoniae infection. Infect Immun., v. 69, p. 1593-1598, 2001.

World Health Organization, WHO. Human leptospirosis: guidance for diagnosis, surveillance and control. [Geneva]: WHO, 2003. 109 p.

XIN, W.; LI, Y.; MO, H.; ROLAND, K. L.; CURTISS, R. $3^{\text {rd }}$. PspA family fusion proteins delivered by attenuated Salmonella enterica serovar Typhimurium extends and enhances protection against Streptococcus pneumoniae. Infect. Immun., v. 77, n. 10, p. 4518-4528, 2009.

YAN, Y.; CHEN, Y.; LIOU, W.; DING, J.; CHEN, J.; ZHANG, J.; ZHANG, A.; ZHOU, W.; GAO, Z.; YE, X.; XIAO, Y. An evaluation of the serological and epidemiological effects of the outer envelope vaccine to leptospira. J. Chin. Med. Assoc., v. 66, n. 4, p. 224-230, 2003.

YAN, W.; FAISAL, S. M.; MCDONOUGH, S. P.; CHANG, C. F.; PAN, M.J.; AKEY, B.; CHANG, Y.F. Identification and characterization of OmpA-like proteins as novel vaccine candidates for Leptospirosis. Vaccine, v. 28, p. 2277-2283, 2010.

ZHANG, Y. X.; LI, J.; GUO, X. K.; WU, C.; BI ,B.; REN, S. X.; WU, C. F.; ZHAO, G. P. Characterization of a novel toxin-antitoxin module, VapBC, encoded by Leptospira interrogans chromosome. Cell Res., v. 14, n. 3, p. 208-216, 2004.

ZHANG, Y. X.; GENG, Y.; BI, B.; HE, J. Y.; WU, C. F.; GUO, X. K.; ZHAO, G. P. Identification and classification of all potential hemolysin encoding genes and their products from Leptospira interrogans serogroup Icterohae-morrhagiae serovar Lai.

Acta. Pharmacol. Sin., v. 26, n. 4, p. 453-461, abr. 2005.

ZUERNER, R. L.; ALT, D.; BOLIN, C. A. IS1533-based PCR assay for identification of Leptospira interrogans sensu lato serovars. J. Clin. Microbiol., v. 33, p. 3284-3289, 1995. 


\section{ANEXO A - Cálculo do valor da $\mathrm{DL}_{50}$ de $L$. interrogans sorovar Pomona baseado no modelo de Reed e Muench, 1938}

Para exemplificar os cálculos de determinação da $\mathrm{DL}_{50}$ usamos uma curva de dose feita com L. interrrogans sorovar Pomoma. Grupos de cinco hamsters foram infectados com $200 \mu 1$ das diluições seriadas $\left(10^{-5}\right.$ a $\left.10^{-11}\right)$ feitas a partir do macerado do fígado de um animal infectado com L. interrogans. Os animais foram observados por 21 dias após o desafio.

Uma das limitações para o cálculo da $\mathrm{DL}_{50}$ neste experimento foi a contagem das bactérias. Na diluição escolhida para o desafio $\left(10^{-6}\right)$ estimou-se pela contagem que havia aproximadamente 120 leptospiras em $200 \mu$ l. Contudo, considerando que na diluição $10^{-11}$ ainda morreram animais, e que, portanto, ainda havia leptospiras (no mínimo uma), pode-se inferir que o número de bactérias na diluição utilizada para o desafio $\left(10^{-6}\right)$ deve ser pelo menos 1000 vezes maior que o estimado pela contagem.

Assim, para calcular a $\mathrm{DL}_{50}$ considerou-se que na diluição $10^{-11}$ foi injetada uma leptospira, efetuando-se a correção do número de bactérias para as demais diluições (Tabela A1).

Apresentamos abaixo os cálculos feitos para a determinação da $\mathrm{DL}_{50}$, em número de leptospiras, e da diluição correspondente a esse valor $\left(\mathrm{DL}_{50}{ }^{*}\right)$, pelo método de Reed e Muench (1938). Estes valores também foram encontrados graficamente, como ilustrado na Figura A1.

Tabela A1 - Parâmetros considerados para o cálculo da $\mathrm{DL}_{50}$ da L. interrogans sorovar Pomona recém isolada do fígado de animal com sintomas de leptospirose.

\begin{tabular}{|c|c|c|c|c|c|c|c|c|c|}
\hline \multirow{2}{*}{ Diluição } & \multirow{2}{*}{$\begin{array}{l}\text { Contagem } \\
\text { em lâmina }\end{array}$} & \multirow{2}{*}{$\begin{array}{l}\text { Número de } \\
\text { leptospiras } \\
\text { corrigido (N) }\end{array}$} & \multirow{2}{*}{$\log _{10}(N)$} & \multirow{2}{*}{$\mathbf{S}$} & \multirow{2}{*}{$\mathbf{M}$} & \multicolumn{3}{|c|}{ Freqüências acumuladas } & \multirow{2}{*}{$\begin{array}{l}\text { \% de mortes } \\
\text { Acumulada d } \\
=\mathrm{c} /(\mathrm{b}+\mathrm{c})\end{array}$} \\
\hline & & & & & & $S(b)$ & $\mathbf{M}(\mathbf{c})$ & $\begin{array}{l}\text { Total } \\
(\mathbf{b}+\mathbf{c})\end{array}$ & \\
\hline $10^{-5}$ & 1200 & $10^{6}$ & 6 & 0 & 5 & 0 & 31 & 31 & 100 \\
\hline $10^{-6}$ & 120 & $10^{5}$ & 5 & 1 & 4 & 1 & 26 & 27 & 96,3 \\
\hline $10^{-7}$ & 12 & $10^{4}$ & 4 & 0 & 5 & 1 & 22 & 23 & 95,7 \\
\hline $10^{-8}$ & 1 & $10^{3}$ & 3 & 0 & 5 & 1 & 17 & 18 & 94,4 \\
\hline $10^{-9}$ & 0 & $10^{2}$ & 2 & 0 & 5 & 1 & 12 & 13 & 92,3 \\
\hline $10^{-10}$ & 0 & 10 & 1 & 1 & 4 & 2 & 7 & 9 & 77,8 \\
\hline $10^{-11}$ & 0 & 1 & 0 & 2 & 3 & 4 & 3 & 7 & 42,9 \\
\hline
\end{tabular}

$\mathrm{S}$ - número de animais sobreviventes à infecção por L. interrogans sorovar Pomona

$\mathrm{M}$ - número de animais que morreram após infecção por L. interrogans sorovar Pomona 


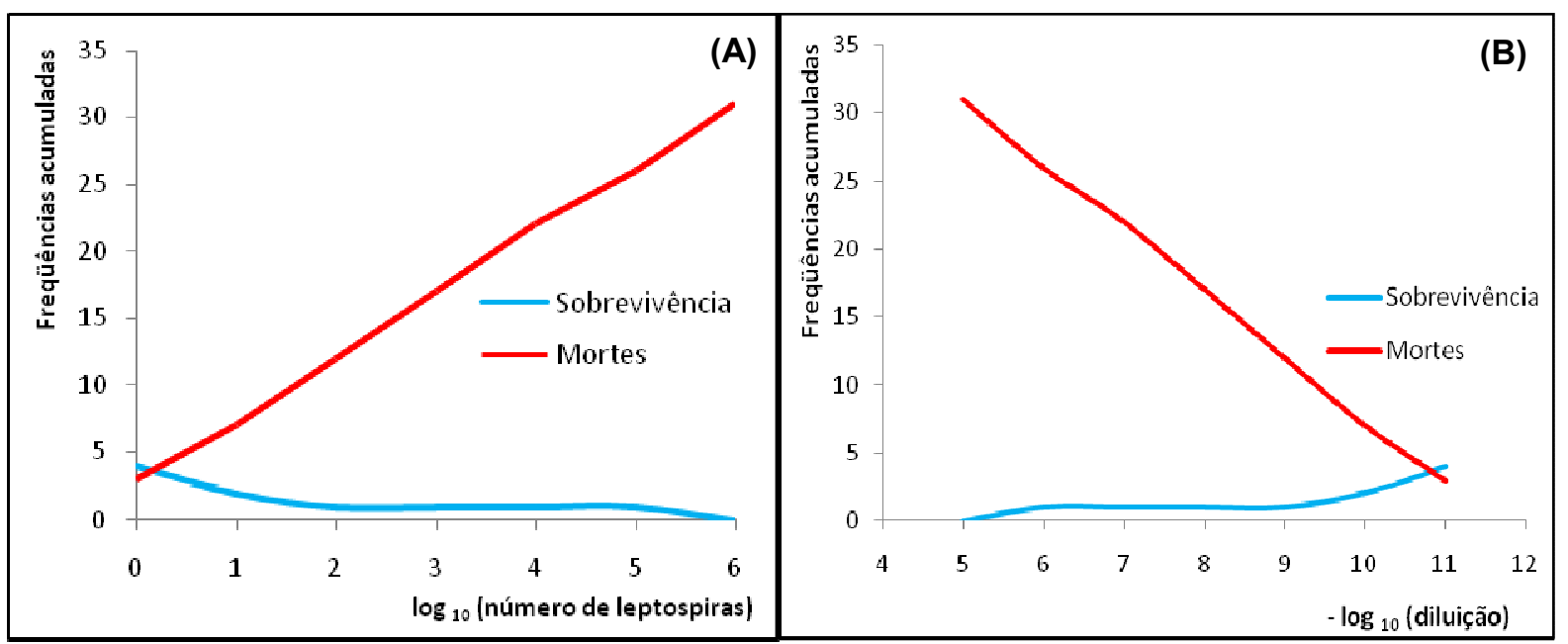

Figura A1 - Relação entre as freqüências acumuladas de sobrevivência e morte, e o número de leptospiras 1njetadas (gráfico A) e as diluições feitas a partir do macerado do fígado de hamster infectado com L. interrogans sorovar Pomona (gráfico B). A $\mathrm{DL}_{50}$ de leptospiras é dada pelo antilog $\log _{10}$ da abscissa do ponto em que as curvas se cruzam no gráfico (A). A diluição correspondente à $\mathrm{DL}_{50}$ é dada pelo negativo do antilog ${ }_{10}$ da abscissa do ponto em que as curvas se cruzam no gráfico (B).

Cálculo da distância proporcional (D) entre o ponto $50 \%$ e a porcentagem cumulativa de mortes abaixo deste ponto

$$
\mathbf{D}=\frac{50 \%-\mathrm{A}}{(\mathrm{B}-\mathrm{A})}
$$

$$
\text { Neste experimento: } \quad \mathbf{D}=\frac{(50-42,9)}{(77,8-42,9)}=0,2
$$

A - $\%$ cumulativa de mortes abaixo do ponto $50 \%$

B - \% cumulativa de mortes acima do ponto $50 \%$

Cálculo da $\mathrm{DL}_{50}$ e da diluição correspondente a esta $\left(\mathrm{DL}_{50}{ }^{*}\right)$

$$
\log _{10}\left(\mathbf{D L}_{\mathbf{5 0}}\right)=\log _{10}(\mathrm{a})+\left[\mathrm{D} \times \log _{10}(\mathrm{~d})\right]
$$

$$
\log _{10}\left(D L_{50}{ }^{*}\right)=\log _{10}\left(a^{*}\right)+\left[D \times \log _{10}(d)\right]
$$

$\mathrm{DL}_{50}$ - número de leptospiras que promove morte de $50 \%$ dos animais infectados

$\mathrm{DL}_{50}{ }^{*}$ - diluição que promove morte de $50 \%$ dos animais infectados

a - número de leptospiras correspondente ao ponto abaixo do $50 \%$

$\mathrm{a}^{*}$ - diluição correspondente ao ponto abaixo do $50 \%$

D - distância proporcional

d - fator de diluição 
Neste experimento:

$$
\begin{gathered}
\log _{10}\left(D L_{50}\right)=\log _{10}(1)+\left[0,2 \times \log _{10}(10)\right] \\
\log _{10}\left(D L_{50}\right)=0,2 \\
\mathbf{D L}_{\mathbf{5 0}}=\mathbf{2} \text { leptospiras }
\end{gathered}
$$

\begin{tabular}{|c|}
\hline $\begin{array}{c}\log _{10}\left(D L_{50}^{*}\right)=\log _{10}\left(10^{-11}\right)+[0,2 x \\
\left.\log _{10}(10)\right] \\
\log _{10}\left(D L_{50}^{*}\right)=-10,8\end{array}$ \\
\hline
\end{tabular}

Segundo os cálculos efetuados, a $\mathrm{DL}_{50}$ seria igual a 2 (duas) leptospiras, ou seja, o correspondente à infecção com $200 \mu 1$ da diluição $10^{-10,8}$ feita a partir do macerado de fígado recém isolado de hamster infectado com L. interrogans sorovar Pomona. Neste ensaio os animais foram desafiados com $200 \mu \mathrm{l}$ da diluição $10^{-6}$, ou seja, com $10^{5}$ leptospiras $\left(5 \times 10^{4} \mathrm{x}\right.$ $\left.\mathrm{DL}_{50}\right)$. 